\title{
Biosignatures of modern microbial mats, Kiritimati/Kiribati, Central Pacific
}

\author{
Dissertation \\ zur Erlangung des mathematisch-naturwissenschaftlichen Doktorgrades \\ "Doctor rerum naturalium" \\ der Georg-August-Universität Göttingen \\ im Promotionsprogramm Geowissenschaften \\ der Georg-August University School of Science (GAUSS)

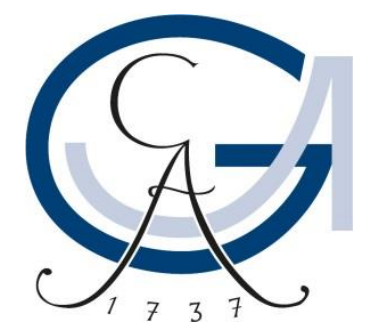 \\ vorgelegt von \\ Yan Shen \\ aus Changsha, China
}

Göttingen, 2019 


\section{Betreuungsausschuss}

Prof. Dr. Joachim Reitner

Abt. Geobiologie, Geowissenschaftliches Zentrum, Georg-August-Universität Göttingen

Prof. Dr. Volker Thiel

Abt. Geobiologie, Geowissenschaftliches Zentrum, Georg-August-Universität Göttingen

\section{$\underline{\text { Mitglieder der Prüfungskommission }}$}

Referent: Prof. Dr. Joachim Reitner

Abt. Geobiologie, Geowissenschaftliches Zentrum, Georg-August-Universität Göttingen

Prof. Dr. Volker Thiel

Abt. Geobiologie, Geowissenschaftliches Zentrum, Georg-August-Universität Göttingen

\section{Weitere Mitglieder der Prüfungskommission}

Prof. Dr. Arp Gernot

Abt. Geobiologie, Geowissenschaftliches Zentrum, Georg-August-Universität Göttingen

PD Dr. Michael Hoppert

Abt. für Allgemeine Mikrobiologie, Georg-August-Universität Göttingen

Dr. Pablo Suarez-Gonzalez

Área de Geología, Universidad Rey Juan Carlos, Madrid, Spain

Dr. Sebastiaan W. Rampen

Abt. Geobiologie, Geowissenschaftliches Zentrum, Georg-August-Universität Göttingen

Tag der mündlichen Prüfung: 20.09.2019 
"That which does not kill us makes us stronger" "There are no beautiful surfaces without a terrible depth" Friedrich Nietzsche 

This work is dedicated to my beloved parents Wanying Zhou and Xianyi Shen. Thank you so much for your unconditional support and encouragement along the way. 



\section{$\underline{\text { Preface }}$}

This thesis are cumulative works, composed of three individual scientific contributions in the form of publications or prepared manuscripts (Chapters 2 to 4 ). These contributions are accompanied by an introduction chapter, a summary outlining the main conclusions of this work as well as an outlook describing the future works (Chapter $1, \underline{5}$ and $\underline{6}$, respectively).

Shen, Y.*, Thiel, V., Duda, J.-P., and Reitner, J. (2018). Tracing the fate of steroids through a hypersaline microbial mat (Kiritimati, Kiribati/Central Pacific), Geobiology, 16, 307-318. (Chapter 2 of this thesis)

Own contribution: implementation of experiments; preparation and analysis of samples; data evaluation; writing of the manuscript.

Shen, Y.*, Thiel, V., Suarez-Gonzalez, P., Rampen, S. W., and Reitner, J. (2019). Sterol preservation in hypersaline microbial mats, Biogeosciences Discussion., 1-28. (Chapter 3 of this thesis)

Own contribution: design and implementation of experiments; analysis of samples; data evaluation; writing of the manuscript.

Shen, Y.*, Suarez-Gonzalez, P., Thiel, V., Martin Blumenberg., and Reitner, J. (in preparation). Different modes of calcification control the preservation of organic matter in a recent microbial mat. To be submitted to Geological Society of America Bulletin. (Chapter 4 of this thesis)

Own contribution: Sample preparation; design and implementation of experiments; data evaluation; writing of the manuscript.

Please note that stylistic features of individual contributions have been adapted to the overall style of this thesis. 



\begin{abstract}
$\underline{\text { Abstract }}$
Organic biomarkers have been widely used to trace the information of their biological precursors and to reveal information about fossil depositional environment, and thus they help to reconstruct ancient ecosystems. Prior to the advent of bioturbation at Ediacaran-Cambrian transitions, pervasive microbial mats covered large areas of Proterozoic oceanic shelves. This contrasts with the Phanerozoic, characterized by the flourishment of metazoans and less common benthic microbial mats. One of the characteristic features of Precambrian biomarker records is that eukaryotic steranes are typically absent or occur in very low concentrations. It is not known whether this feature reflects the scarcity of eukaryotic primary producers in Proterozoic environments, or rather the preferential degradation of eukaryotic lipids in the widespread benthic microbial mats (proposed as "mat-seal effect"). One of the main goals of this $\mathrm{PhD}$ work is to test this hypothesis, demonstrating the preservation pathways of eukaryote-derived steroids as well as other lipid biomarkers (e.g. bacteria-derived hopanoids and fatty acids) in modern microbial mat settings. This work will provide new insights into the potential taphonomic bias of eukaryotic steroids, in contrast to other lipids, in distinct microbial mat ecosystems.
\end{abstract}

This thesis aims at 1) assessing the fate of total extractable steroids in microbial mats; 2) differentiating the preservation pathways of sterols between freely extractable lipids, carbonate-bound lipids and the non-extractable residues, and testing if calcification within microbial mats may function as a preservation mechanism for these biomarkers; 3) examining the taphonomy of $\mathrm{OM}$ and microfacies in microbial mats, and providing reference data for the relations between the preservation of $\mathrm{OM}$ and the associated mineralization modes. To this end, I performed several studies in which I used different techniques to provide answers for specific research questions.

In the first study, a c. 1200 yrs old microbial mat from a hypersaline Lake 22 on Kiritimati was investigated to analyze the fate of steroids. This mat was divided into different layers, and the biomarker inventory in the total lipid extracts (including steroids) was assessed and quantified in each mat layer. It was demonstrated that the steroids experienced anaerobic microbial transformation along distinctive diagenetic pathways (stenols $=>$ stanols $\Rightarrow>$ sterenes $=>$ steranes), however, the total amount of the compounds with the steroid skeleton retained markedly constant on a $10^{3}$ yrs scale, and hence, the results contradict with the so called "mat-seal effect".

The second study examined the taphonomic pathways of eukaryotic sterols, as freely extractable and carbonate-bound lipids, in a c. 1500 yrs hypersaline microbial mat (Lake 2, Kiritimati, Central Pacific), to test if calcification within microbial mats may function as a preservation mechanism for 
these biomarkers. In addition, the results in this work were compared to other studies performed on microbial mats from different settings (including other lakes on Kiritimati) to obtain better insight in which factors affect the preservation of sterols in hypersaline microbial mat systems. This work illustrated 1) that the carbonate matrix played no important role in encasing sterols in the mat that was analysed for this study, 2) that a significant drop in total sterols concentration was observed immediately below the top layer and retained in a low abundance in deeper layers, indicating in favor of "mat-seal effect" theory; and 3) the discrepancies with respect to the preservation of sterols in the two Kiritimati mats (i.e., Lake 2 and 22) might be linked to the differences in salinity or to periods of subaerial exposure, suggesting that sterols would have a higher preservation potential in microbial mats experiencing stronger salinities or more desiccated conditions.

As for the third study, the analysis of lipid biomarkers was combined with petrographic and histologic investigation, in a depth profile of a recent calcifying mat (the same mat as investigated in the second study) from a hypersaline Lake 2 in Kiritimati. This work aims at a better understanding of the processes that lead to mineralization of a microbial mat and the preservation of organic matter in the resulting microbialites. This study shows for the first time that significantly different organic matter preservation pathways are observed even within a single microbial mat. In addition, the data illustrate that preservation of lipids may have been strongly controlled by mineralization processes. Fast mineral precipitation driven by environmental changes might preserve microbial lipid signatures much better than relatively slow mineralization driven by progressive EPS degradation in deeper mat layers.

Finally, this thesis demonstrates that the preservation of steroids is not only regulated by heterotrophic degradation, but rather reflects a complex interplay of taphonomic processes, and it may be also associated with multiple biotic and abiotic factors including salinity and periods of subaerial exposure. Therefore, caution has to be taken in the interpretation of sterols distribution patterns in modern and ancient microbial mat settings. Moreover, future works on microbial lipids in fossil microbialites should thoroughly consider the mineralization processes to reach sound interpretations on organic biosignatures enclosed therein. 


\section{Kurzfassung}

Organische Biomarker werden häufig verwendet um Informationen über ihre biologischen Vorläufer und über die fossile Ablagerungsumgebung $\mathrm{zu}$ erhalten, womit sie zur Rekonstruktion alter Ökosysteme beitragen. Vor Beginn der Bioturbation an der Ediakarium-Kambrium-Grenze bedeckten mikrobielle Matten große Bereiche der proterozoischen ozeanischen Schelfgebiete. Dies steht im Gegensatz zum Phanerozoikum, das durch die Entfaltung von Metazoen und weniger verbreiteten benthischen mikrobiellen Matten gekennzeichnet ist. Eines der charakteristischen Merkmale der präkambrischen Biomarkeraufzeichnungen ist, dass eukaryotische Sterane typischerweise fehlen oder in sehr niedrigen Konzentrationen vorkommen. Es ist nicht bekannt, ob dieses Phänomen die Knappheit eukaryotischer Primärproduzenten in proterozoischen Umgebungen widerspiegelt, oder vielmehr den bevorzugten Abbau eukaryotischer Lipide in den weit verbreiteten benthischen mikrobiellen Matten (vorgeschlagen als "mat-seal effect"). Eines der Hauptziele dieser Doktorarbeit ist es, diese Hypothese zu testen und die Konservierungswege von Steroiden aus Eukaryoten sowie anderen Lipid-Biomarkern (z.B. bakterielle Hopanoide und Fettsäuren) in modernen mikrobiellen Mattensituationen aufzuzeigen. Eines der Hauptziele dieser Doktorarbeit ist es, diese Hypothese zu testen und die Konservierungswege von Steroiden aus Eukaryoten sowie anderen Lipid-Biomarkern (z.B. bakterielle Hopanoide und Fettsäuren) in modernen mikrobiellen Matten aufzuzeigen. Diese Arbeit wird neue Erkenntnisse über die potenzielle taphonomische Verzerrung eukaryotischer Steroide, verglichen mit anderen Lipiden, in verschiedenen mikrobiellen Mattenökosystemen liefern.

Mit einer Reihe von Experimenten zielt diese Arbeit darauf ab, 1) das Schicksal frei extrahierbarer Steroide in mikrobiellen Matten zu beurteilen; 2) die Konservierungswege von Sterolen zwischen frei extrahierbaren Lipiden, karbonatgebundenen Lipiden und den nicht extrahierbaren Rückständen zu unterscheiden und $\mathrm{zu}$ testen, ob die Kalzifizierung innerhalb der mikrobiellen Matte als Konservierungsmechanismus für diese Biomarker funktionieren kann; 3) die Taphonomie von OM und Mikrofazies in mikrobiellen Matten zu untersuchen und Referenzdaten für die Beziehungen zwischen der Erhaltung von OM und den zugehörigen Mineralisierungsmethoden bereitzustellen.

In der ersten Studie wurde eine ca. 1200 Jahre alte mikrobielle Matte aus dem hypersalinaren See 22 auf Kiritimati untersucht, um das Verhalten von Steroiden zu analysieren. Diese Matte wurde in verschiedene Schichten aufgeteilt und die Biomarker in den gesamten Lipidextrakten (einschließlich Steroide) wurden in jeder Mattenschicht bewertet und quantifiziert. Es konnte gezeigt werden, dass die Steroide eine anaerobe mikrobielle Transformation entlang ausgeprägter diagenetischer Pfade durchlaufen haben (Stenole $\Rightarrow$ Stanole $=>$ Sterene $\Rightarrow$ Sterane), wobei jedoch die Gesamtmenge der Verbindungen mit Steroidskelett auf einer $10^{3}$-jährigen Skala deutlich konstant blieb und damit gegen den "mat-seal-effect". 
Die zweite Studie untersuchte die taphonomischen Pfade eukaryotischer Sterole als frei extrahierbare und karbonatgebundene Lipide in einer neueren hypersalinaren mikrobiellen Matte (See 2, Kiritimati, Zentralpazifik), um zu testen, ob die Kalzifizierung innerhalb der mikrobiellen Matte als Konservierungsmechanismus für diese Biomarker dienen kann. Darüber hinaus wurden die Ergebnisse dieser Arbeit mit anderen Studien verglichen, die an mikrobiellen Matten aus verschiedenen Umgebungen (einschließlich anderer Seen auf Kiritimati) durchgeführt wurden, um einen besseren Einblick in die Erhaltung von Sterolen in hypersalinaren mikrobiellen Mattensystemen zu erhalten. Diese Arbeit verdeutlichte 1), dass die Karbonatmatrix keine wichtige Rolle bei der Umhüllung von Sterolen in der untersuchten Matte spielte, 2) dass ein signifikanter Rückgang der Gesamtsterolkonzentration unmittelbar unter der oberen Schicht beobachtet wurde und in geringer Menge in tieferen Schichten beibehalten wurde, was auf den "mat-seal effect" hinweist; und 3) die Diskrepanzen in Bezug auf die Konservierung von Sterolen in den beiden Kiritimati-Matten (d.h. See 2 und 22) könnten mit den Unterschieden in der Salinität oder mit Perioden subaerischer Unterbrechung zusammenhängen, was darauf hindeutet, dass Sterole ein höheres Konservierungspotenzial in mikrobiellen Matten unter stärkeren Salinitäten oder trockeneren Bedingungen hätten.

In der dritten Studie wurde die Analyse von Lipid-Biomarkern mit petrografischen und histologischen Untersuchungen am Tiefenprofil einer kürzlich verkalkenden Matte ( 1500 Jahre) aus dem hypersalinaren See 2 in Kiritimati ergänzt. Diese Arbeiten zielen auf ein besseres Verständnis der Prozesse ab, die zur Mineralisierung einer mikrobiellen Matte und zur Erhaltung der organischen Substanz in den resultierenden Mikrobialiten führen. Diese Studie zeigt zum ersten Mal, dass signifikant unterschiedliche Wege zur Erhaltung der organischen Substanz auch innerhalb einer einzigen mikrobiellen Matte beobachtet werden. Darüber hinaus zeigen die Daten, dass die Konservierung von Lipiden möglicherweise stark durch Mineralisierungsprozesse gesteuert wurde. Schnelle Mineralfällung aufgrund von Umweltveränderungen könnte die mikrobiellen Lipidsignaturen viel besser bewahren als eine relativ langsame Mineralisierung, die durch den fortschreitenden EPSAbbau in tieferen Mattenschichten verursacht wird.

Schließlich zeigte diese Arbeit, dass die Erhaltung von Steroiden nicht nur durch heterotrophen Abbau reguliert wird, sondern vielmehr ein komplexes Zusammenspiel taphonomischer Prozesse widerspiegelt und auch mit mehreren biotischen und abiotischen Faktoren in Verbindung gebracht werden kann, einschließlich Salzgehalt und Perioden subaerischer Einwirkung. Daher ist bei der Interpretation der Sterolverteilung in modernen und alten mikrobiellen Matten Vorsicht geboten. Darüber hinaus sollten zukünftige Arbeiten zu mikrobiellen Lipiden in fossilen Mikrobialiten die Mineralisierungsprozesse gründlich prüfen, um fundierte Interpretationen der darin enthaltenen organischen Biosignaturen zu erreichen. 


\section{Contents}

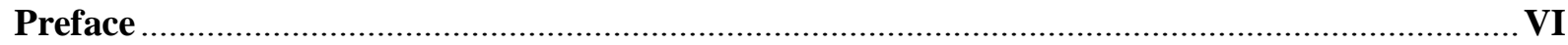

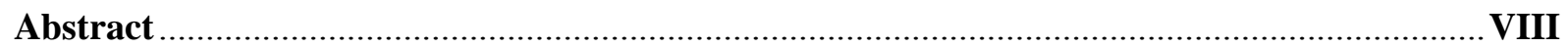

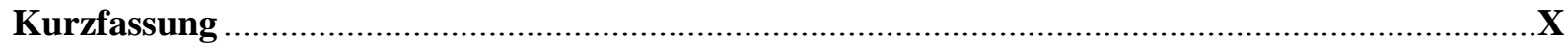

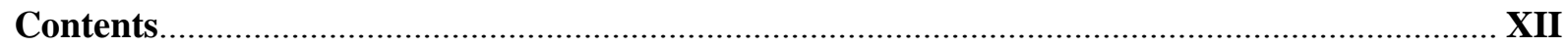

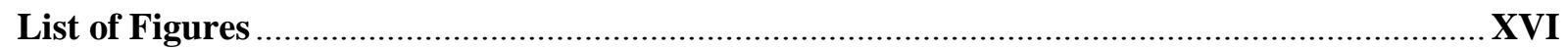

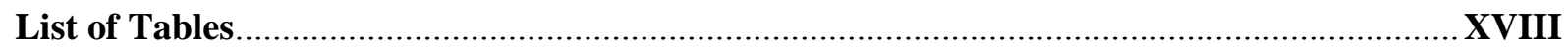

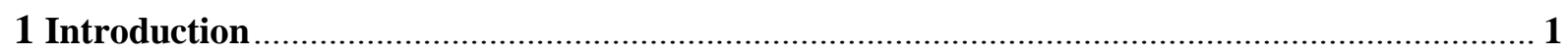

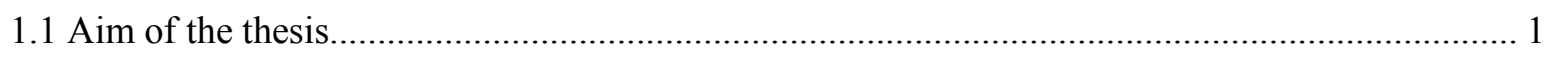

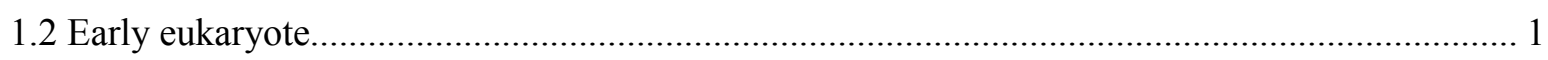

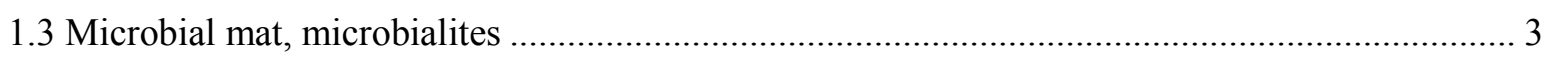

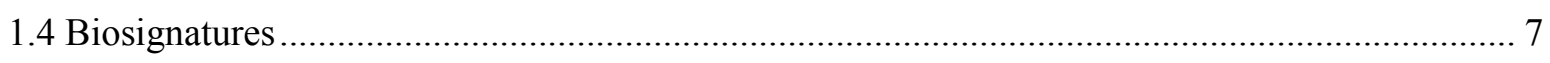

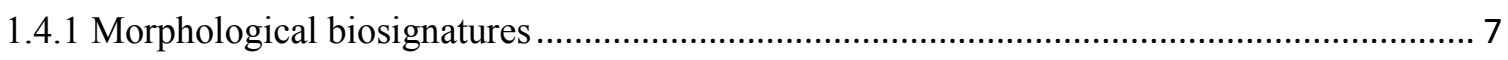

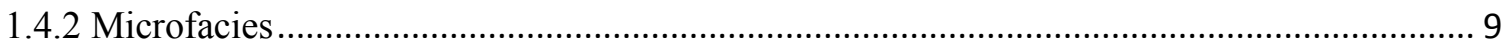

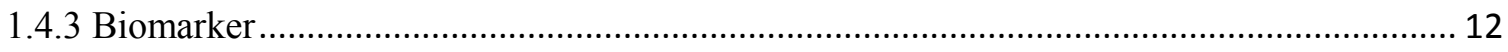

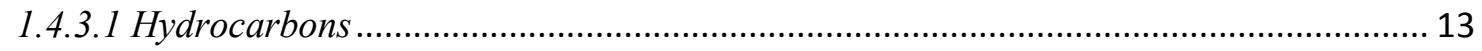

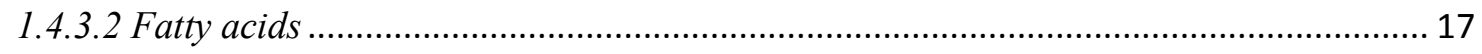

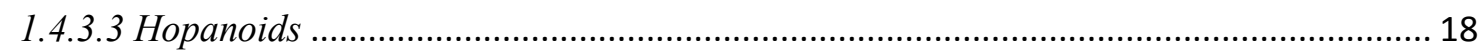

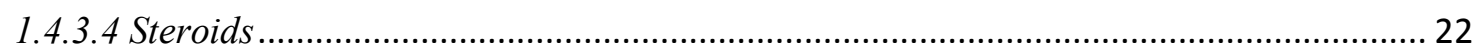

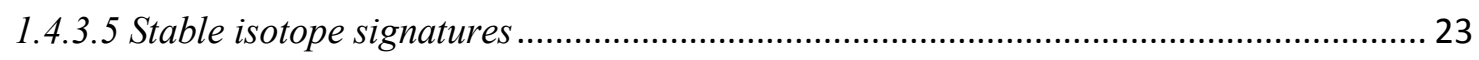

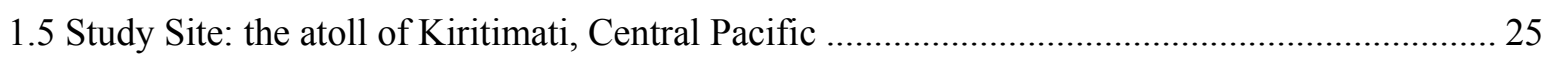

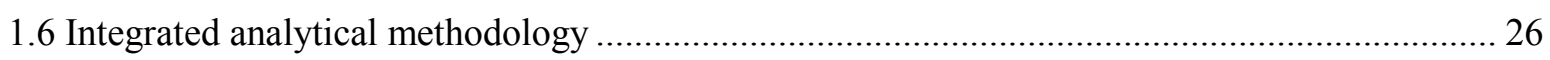

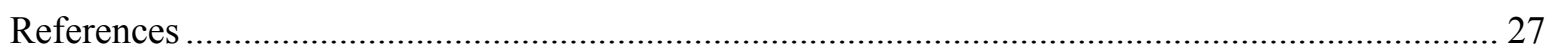

2 Tracing the fate of steroids through a hypersaline microbial mat (Kiritimati, Kiribati/Central

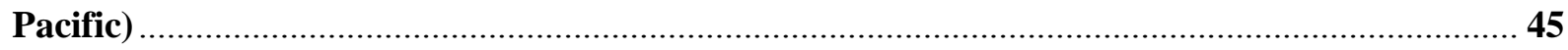

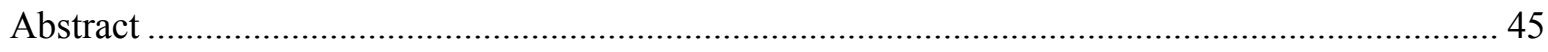

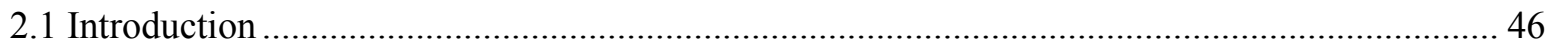




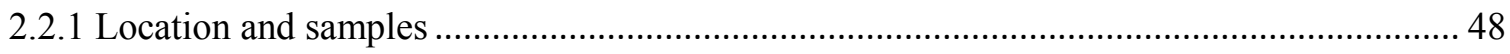

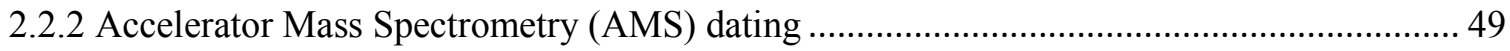

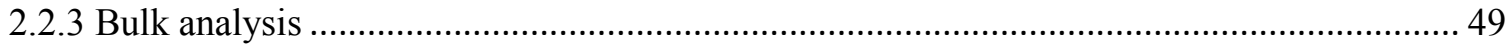

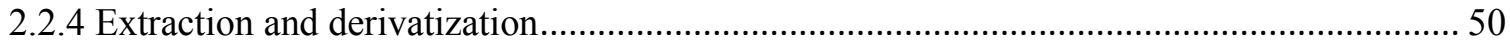

2.2.5 Gas chromatography-mass spectrometry (GC-MS) …....................................................... 50

2.2.6 Pyrolysis-gas chromatography-mass spectrometry (Py-GC-MS) …................................... 50

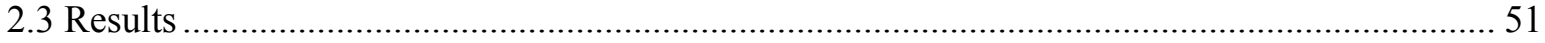

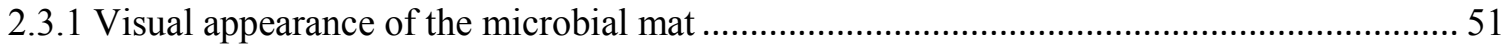

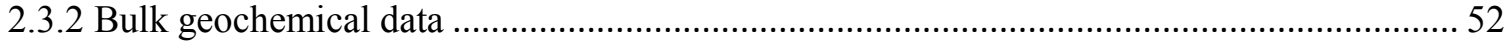

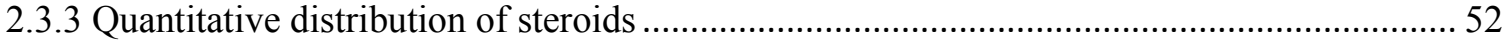

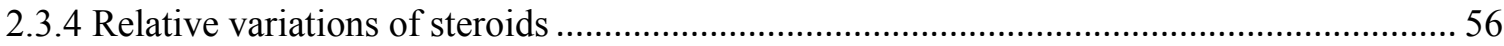

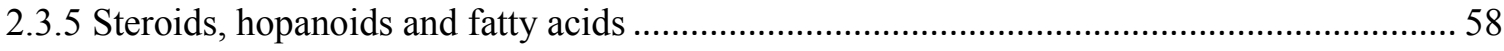

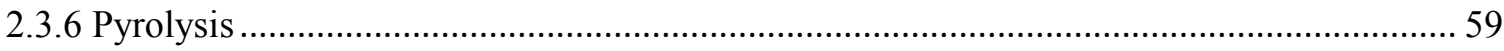

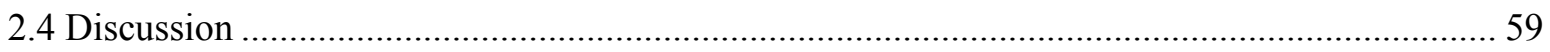

2.4.1 Sources and diagenetic pathways of steroids ..................................................................... 59

2.4.2 Depth distributions of steroids vs. hopanoids and fatty acids (FAs) ................................... 61

2.4.3 Preservation of eukaryotic steroids - taphonomically biased? ............................................. 62

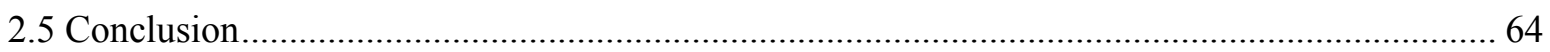

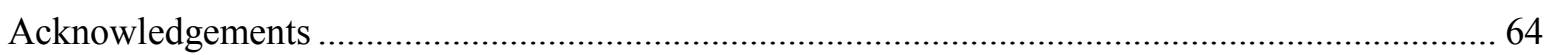

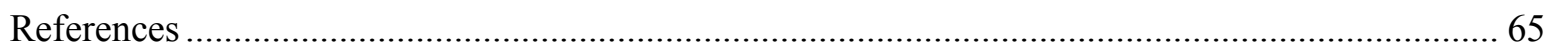

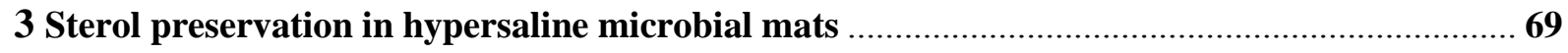

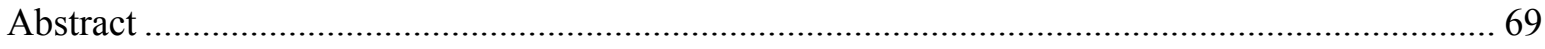

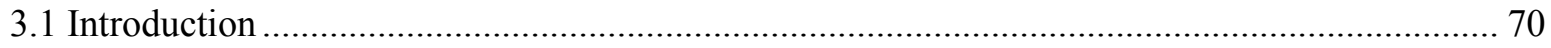

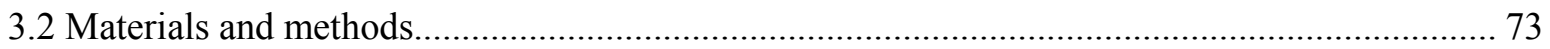

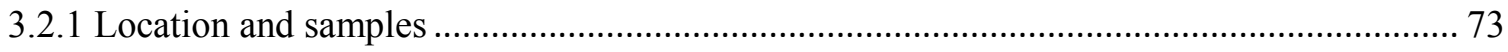

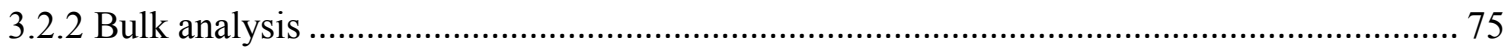

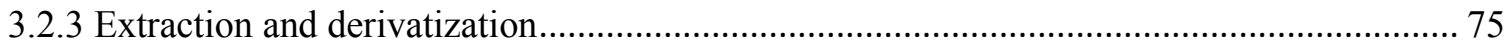

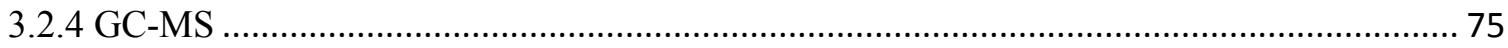

3.2.5 Pyrolysis-gas chromatography-mass spectrometry (Py-GC-MS) ……………................... 76

3.2.6 Compound-specific stable carbon isotopes analysis ............................................................. 76

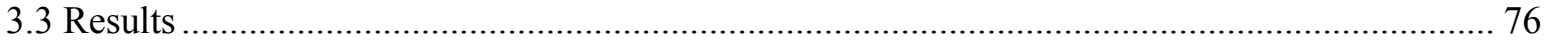




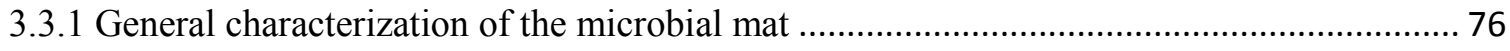

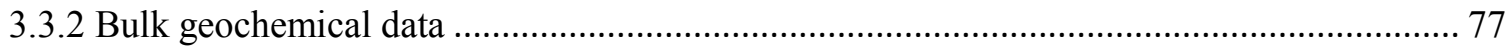

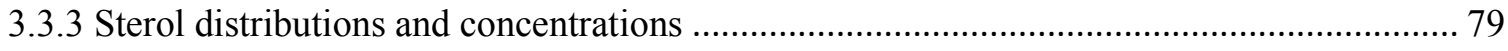

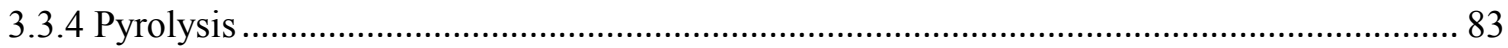

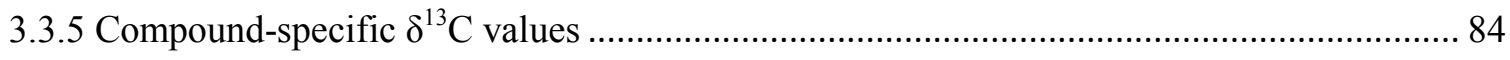

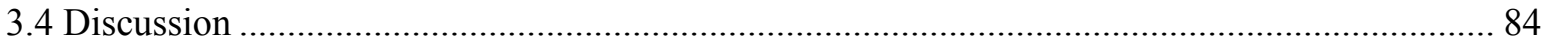

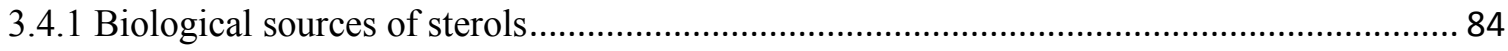

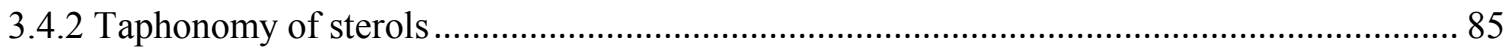

3.4.3 Comparison with sterol taphonomy in other microbial mats ............................................ 87

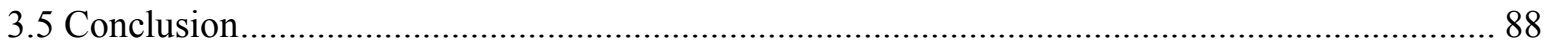

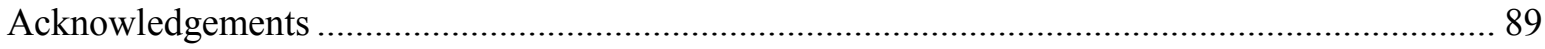

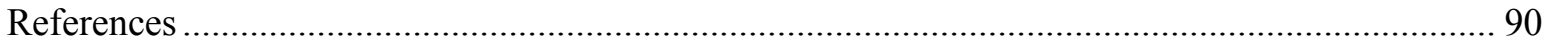

4 Different modes of calcification control the preservation of organic matter in a recent

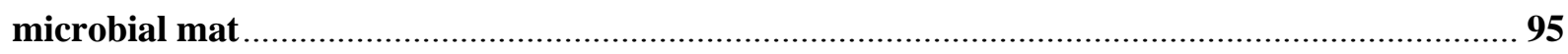

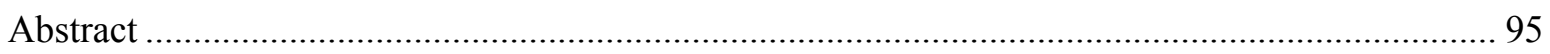

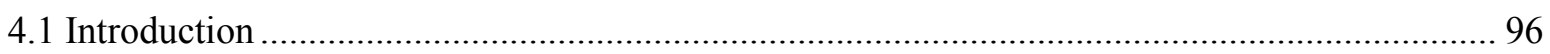

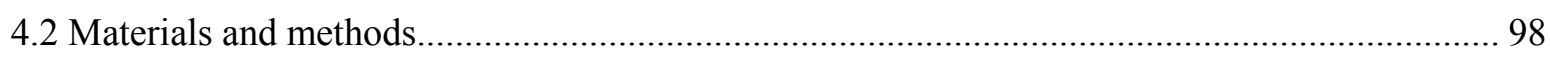

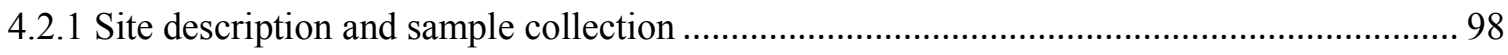

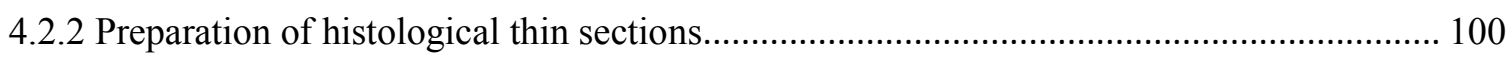

4.2.3 Preparation for the electron microscope ................................................................... 100

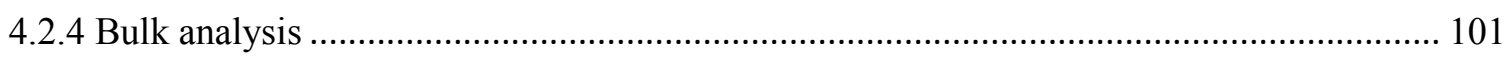

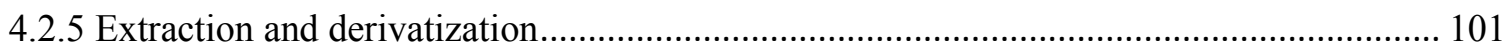

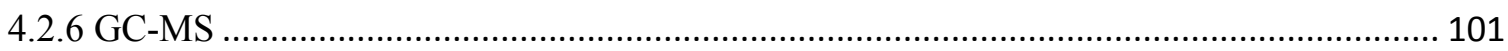

4.2.7 Pyrolysis-gas chromatography-mass spectrometry (Py-GC-MS) ….................................. 102

4.2.8 Compound-specific stable carbon isotopes (GC-C-IRMS) …........................................... 102

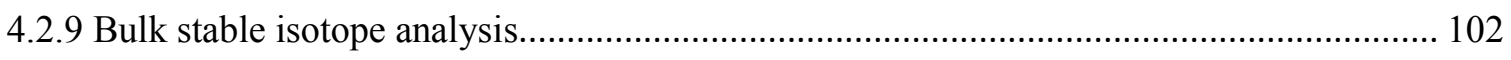

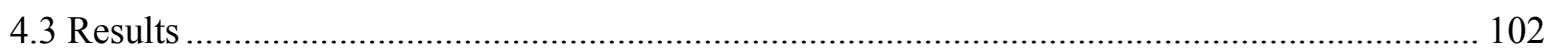

4.3.1 Description of mat layers at macro- and micro-scale ...................................................... 102

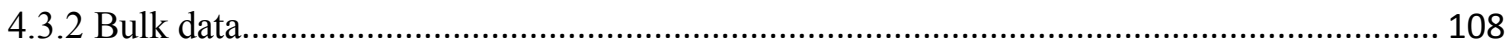

4.3.3 Qualitative GC-amenable hopanoids and FAs ................................................................... 109

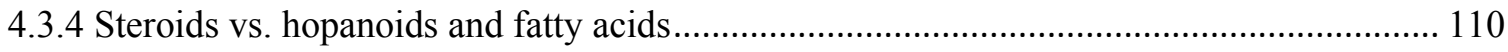

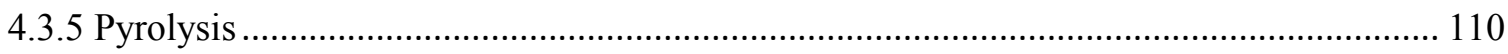

4.3.6 Carbon isotopic compositions of microbial lipids and hydrocarbons ............................... 111 


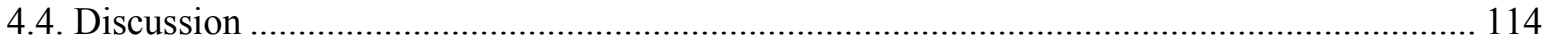

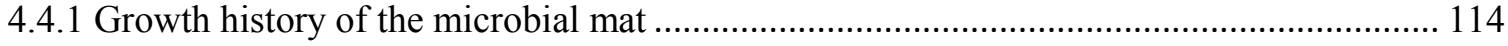

4.4.2 Depth distributions of steroids vs. hopanoids and fatty acids (FAs) ................................ 116

4.4.3 Stable carbon isotope signatures for microbial lipids $\left(\delta^{13} \mathrm{C}_{\text {lipid }}\right)$ and bulk carbonate $\left(\delta^{13} \mathrm{C}_{\text {carb }}\right)$

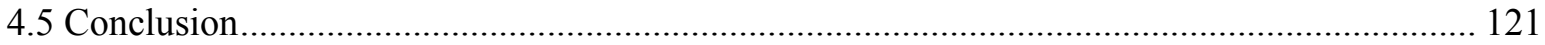

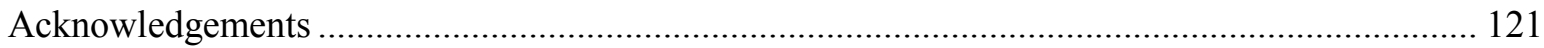

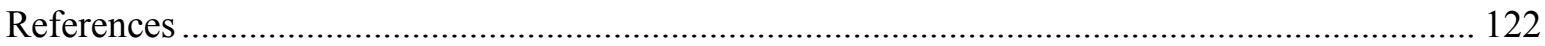

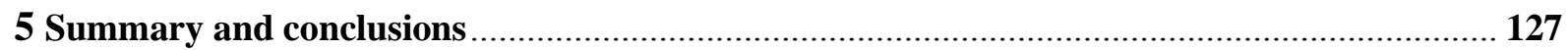

6 Outlook

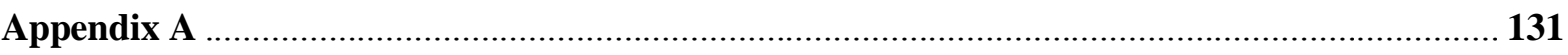

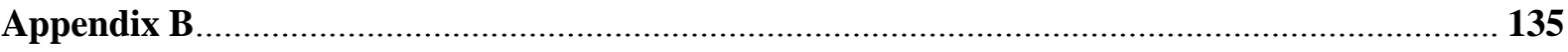

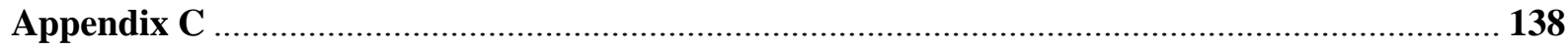

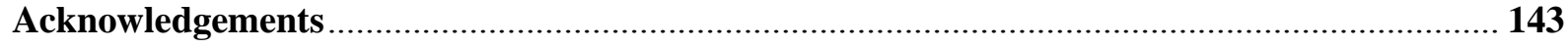




\section{List of Figures}

Figure 1.1 Examples of microbial mats and ancient microbialites................................................ 4

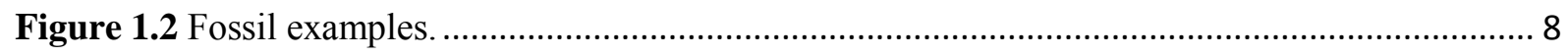

Figure 1.3 Microfacies examples in Kiritimati microbial mats....................................................... 10

Figure 1.4 Examples of hydrocarbons showing the carbon skeletons............................................. 14

Figure 1.5 Examples of fatty acids showing the carbon skeletons .................................................. 17

Figure 1.6 Examples of hopanoids showing the carbon skeletons .................................................. 20

Figure 1.7 Examples of steroids showing the carbon skeletons .................................................... 21

Figure 1.8 Location of the atoll of Kiritimati in the Pacific Ocean and its satellite image showing

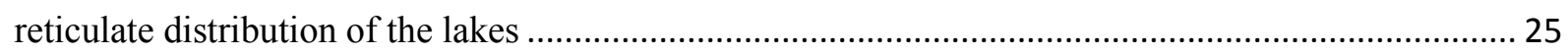

Figure 2.1 Map of Kiritimati atoll and the enlarged view of the study site....................................... 47

Figure 2.2 The analyzed microbial mat from Lake 22 ................................................................ 49

Figure 2.3 Partial GC-MS chromatograms showing sterol distributions in the microbial mat ............ 55

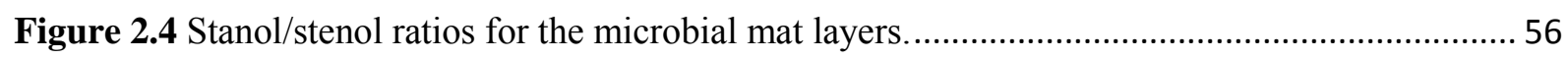

Figure 2.5 Sterene/stenol ratios for the microbial mat layers......................................................... 57

Figure 2.6 Proportions of different steroid classes in the microbial mat layers. ................................. 58

Figure 2.7 Abundances of steroids, hopanoids, fatty acids and $\mathrm{C}_{\text {org }}(\mathrm{wt} . \%)$ in the microbial mat layers.

Figure 3.1 Location of Kiritimati atoll in the Pacific Ocean and the microbial mat sample from Lake 2

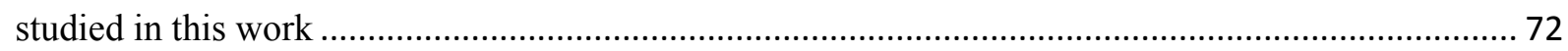

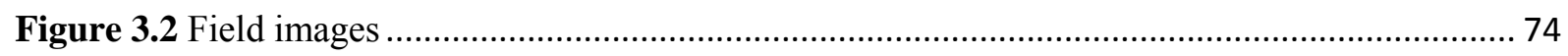

Figure 3.3 $\mathrm{C}_{\text {org }}$ and $\mathrm{CaCO}_{3}$ contents and the distribution of sterols in the microbial mat ................... 78

Figure 3.4 Partial GC-MS chromatograms showing the freely extractable sterols in the microbial mat.

Figure 3.5 Distributions and concentrations of $\mathrm{C}_{27}-\mathrm{C}_{29}$ sterols in the microbial mat layers................ 81

Figure 3.6 Stanol/stenol ratios for the microbial mat layers......................................................... 82

Figure 4.1 General location of Kiritimati atoll in the Pacific Ocean and the related information of the

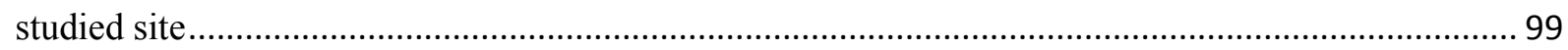

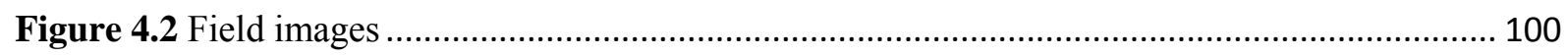

Figure 4.3 Close-up picture of the frozen microbial mat sample studied in this work...................... 103

Figure 4.4 Mineral precipitates observed within the studied microbial mat ................................... 105

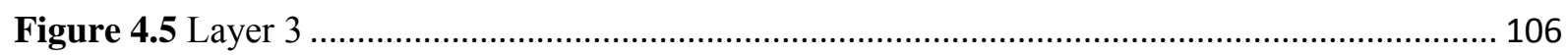

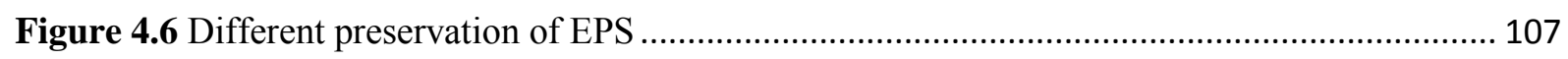

Figure 4.7 Depth distribution of steroids, hopanoids, fatty acids and $\mathrm{C}_{\text {org }}$ in the microbial mat layers

Figure A.1: Mass spectrum of the $\mathrm{C}_{27}$ thiosterane observed in layer 5 of the microbial mat 
Figure A.2: Summed Pyrolysis-GC-MS chromatograms of steroids and hopanoids from microbial mat extraction residues. 134

Figure B.1: Mass spectra of $4 \alpha$-methylgorgosterol and $4 \alpha$-methylgorgostanol observed in the studied microbial mat.

Figure B.2: Pyrolysis-GC-MS chromatograms showing the distributions of steroids in the insoluble organic matter of the microbial mat layers.

Figure B.3: Distributions of summed $\mathrm{C}_{27^{-}}$vs. $\mathrm{C}_{28}$ - vs. $\mathrm{C}_{29}$ - vs. $\mathrm{C}_{31}$-sterols in the microbial mat layers

Figure C.1: Summed Pyrolysis-GC-MS chromatograms of steroids and hopanoids from the remaining extract residues within the microbial mat... 


\section{$\underline{\text { List of Tables }}$}

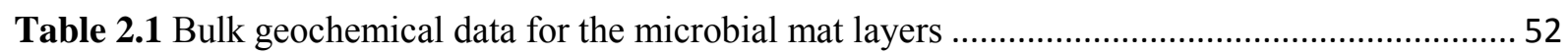

Table 2.2 Concentrations of steroids in the microbial mat layers........................................................ 54

Table 2.3 Stanol/stenol and sterene/stenol ratios for the microbial mat layers.................................. 56

Table 3.1a Bulk geochemical data for the microbial mat (original mat layers) ................................. 78

Table 3.1b Bulk geochemical data for the microbial mat (extraction residues) .................................. 78

Table 3.2a Concentrations of sterols in the freely extractable lipids of the microbial mat layers........ 80

Table 3.2b Concentrations of sterols in the carbonate-bound lipids of the microbial mat layers......... 80

Table 3.3 Stanol/stenol ratios in the freely extractable lipids and carbonate-bound lipids for the

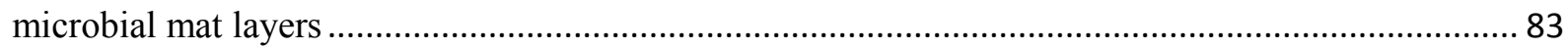

Table 4.1a Bulk geochemical data for the microbial mat layers (original mat layers) ...................... 108

Table 4.1b Bulk geochemical data for the microbial mat layers (extraction residues) ..................... 108

Table 4.2 Carbon isotopic signatures of lipid biomarkers observed in the studied mat .................... 112

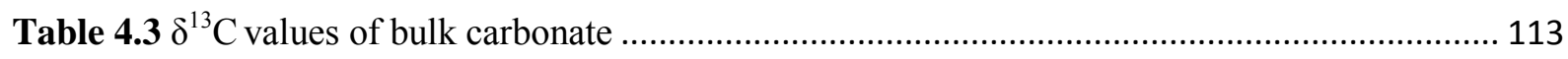

Table A.1: Concentrations of major fatty acids and hopanoids in the microbial mat layers ............. 131

Table A.2: Concentrations of summed major hopanoids, fatty acids and steroids as well as steroids/hopanoids and steroids/FAs ratios in the microbial mat layers.

Table C.1: Concentrations of major fatty acids and hopanoids in the freely extractable lipids of the microbial mat layers

Table C.2: Concentrations of major fatty acids and hopanoids in the carbonate-bound lipids of the microbial mat layers

Table C.3: Concentrations of summed major hopanoids, fatty acids and steroids as well as steroids/hopanoids and steroids/FAs ratios in the freely extractable lipids of the microbial mat layers.

Table C.4: Concentrations of summed major hopanoids, fatty acids and steroids as well as steroids/hopanoids and steroids/FAs ratios in the carbonate-bound lipids of the microbial mat layers. 



\section{-Chapter 1-}

\section{$\underline{\text { Introduction }}$}

\subsection{Aim of the thesis}

This work was performed at the Department of Geobiology, University of Göttingen, and it was done as part of the DFG project "Geobiology of Organo- and Biofilms" (Re 665/18-2 and Research Unit 571). One of the main goals of the thesis is to test the hypotheses on the preservation pathways of organic lipid biomarkers in natural microbial mat settings. The other goal is to examine the mineralization of microbial mat and the preservation of organic matter $(\mathrm{OM})$ in the resulting microbialites. With experimental studies and analytical data, this investigation provides detailed information about the preservation of biosignatures within the studied microbial mats, including microfacies components, lipid biomarkers (eukaryotederived steroids as well as microbial-derived hopanoids and fatty acids) and stable isotope signatures. These results offer novel insights for the taphonomy of OM and the search of original $\mathrm{OM}$ in ancient microbialites.

The thesis aims at:

- Assessing the fate of total extractable steroids in microbial mats;

- Differentiating the preservation pathways of sterols between freely extractable lipids, carbonate-bound lipids and the non-extractable residues, and testing if calcification within microbial mats may function as a preservation mechanism for these biomarkers;

- Examining the taphonomy of OM and microfacies in microbial mats, and providing reference data for the relations between the preservation of $\mathrm{OM}$ and the associated mineralization modes.

\subsection{Early eukaryote}

The earliest steranes of demonstrably eukaryotic origin have been reported from late Archean sedimentary rocks (2700 Mya old shales from the Pilbara Craton, Australis) (Brocks et al., 1999). Although several issues are concerned with respect to the eukaryote fossils (Knoll, 2014), most of them have been clarified (see below). 
The first concern relates to environmental conditions, i.e., molecular $\mathrm{O}_{2}$ is a known prerequisite for sterol biosynthesis, which contradicts the geochemical data revealing anaerobic atmosphere and oceans in the Archean (Holland, 2006). Jahnke (1986) and Waldbauer et al. (2011) demonstrated possible sterol synthesis at very low thresholds, and in addition, the presence of small amounts of $\mathrm{O}_{2}$ in the marine environment could have been persistent for long periods of time, prior to the accumulation of significant levels of atmospheric $\mathrm{O}_{2}$ (the Great Oxidation Event, Anbar et al., 2007; Planavsky et al., 2014a). This corroborates the possible situations that enable the production of their oldest eukaryote fossils. Second, certain groups of bacteria are capable of synthesizing sterols (Pearson, Budin and Brocks, 2003), causing the debate about probable prokaryotic origin of these preserved steranes. However, so far, only some products such as lanosterol are related to bacterial sterol synthesis, while complex steranes were detected in Late Archean samples. It is therefore reasonable to consider this sterane as eukaryotic origin. The third issue is the contamination, because only trace amounts of sterane (part-per-billion concentrations) occur in Archean rocks. In this regard, biomarkers can be potentially emplaced by fluid flow during sedimentary or diagenetic processes, or by the drilling procedure, even by the sample preparation. As a result, stringent protocols for drilling and sample analysis have been developed, to avoid ambiguous sterane signatures.

Molecular clocks (calibration with phylogenetical fossils, Knoll, 2014) suggest that the last common ancestor of extant eukaryotes emerged during the Proterozoic Eon, which is concordant with permanent oxygenation of Earth's atmosphere and surface ocean occurred c. 2400 Mya (Holland, 2006) as well as with stable atmospheric $\mathrm{O}_{2}$ (ca. $0.1 \%$ of present atmospheric level) in mid-Proterozoic (Planavsky et al., 2014b). Moderate expansion of eukaryotic organisms occurred in the Mesoproterozoic oceans, and subsequent major eukaryotic diversification appears to have begun in the Neoproterozoic (c. 800 Mya), documented by the increasing taxonomic richness of complex, organic-walled microfossils (Knoll et al., 2007; Knoll, 2014). On the other hand, the preserved molecular fossils in Proterozoic oceans are dominated by cyanobacteria and other photosynthetic bacteria, indicating that eukaryotes played a limited quantitative role in primary production at that time (Knoll et al., 2007). Another evidence, which demonstrates the major radiation of eukaryotes at the end of the Proterozoic, is the increasing amounts of $\mathrm{C}_{29}$ steranes detected in Late Neoproterozoic (Ediacaran) samples (Grantham, 1986), suggesting eukaryotic algae may have become the major primary producer in the oceans (excluding terrestrial plants-derived $\mathrm{C}_{29}$ 
steranes, because their earliest microfossils are found in Late Ordovician-Silurian rocks, Gray and Boucot, 1978; Morris et al., 2018).

Further evidence for the proliferation of eukaryotes in Ediacaran is the relatively high abundances of isopropylcholestane, ascribed to sponges that played a role in primary production (Love et al., 2009; McCaffrey et al., 1994a). Apparently, this eukaryotic radiation did not finish by the latest Proterozoic; instead, most of eukaryotes are the product of Phanerozoic evolution. Fossils provide evidences of proliferation of complex multicellular organisms, such as animals, land plants as well as fungi (Knoll, 2011).

As noted above, the evolution of eukaryotes is intimately correlated with the oxygenation of oceans and atmosphere. For instance, a more enriched $\mathrm{O}_{2}$ in Phanerozoic ecosystems as compared to the Proterozoic counterpart, facilitate the radiation of animals in Cambrian oceans (Dahl et al., 2010). Over billions years of evolution, and throughout the many environmental changes, the remarkable prosperity of eukaryotes has made significant contributions to the complex biota (including flora and fauna) of modern Earth.

\subsection{Microbial mat, microbialites}

Microbial mats are complex, millimeter to centimeter scale self-sustaining ecosystems (see Figure 1.1). They have been present on Earth for billions of years, and developed under a wide range of environmental conditions such as hydrothermal vents, hypersaline coastal lagoons, alkaline lakes, cold seeps, hot springs and interdidal flats (Crépeau et al., 2011; Ramos et al., 2017; Spring et al., 2015; Arp, Hofmann and Reitner, 1998; Prieto-Barajas, Valencia-Cantero and Santoyo, 2018; Reitner et al., 2005; Thiel et al., 2001; Guerrero and de Wit, 1992; Shiea, Brassel and Ward, 1991; Schuler, Havig and Hamilton, 2017; van der Meer, 2002; Mackenzie, Pedrós-Alió and Díez, 2013; Scherf and Rullkötter, 2009; Słowakiewicz et al., 2016). The oldest fossil microbial mats have been found in Archaea sedimentary rocks from west Australia (c. 3.5 Ga, Allwood et al., 2006; Noffke et al., 2013) and South Africa (c. 3.2 Ga, Noffke et al., 2006; c. 3.4 Ga, Tice and Lowe, 2004). 

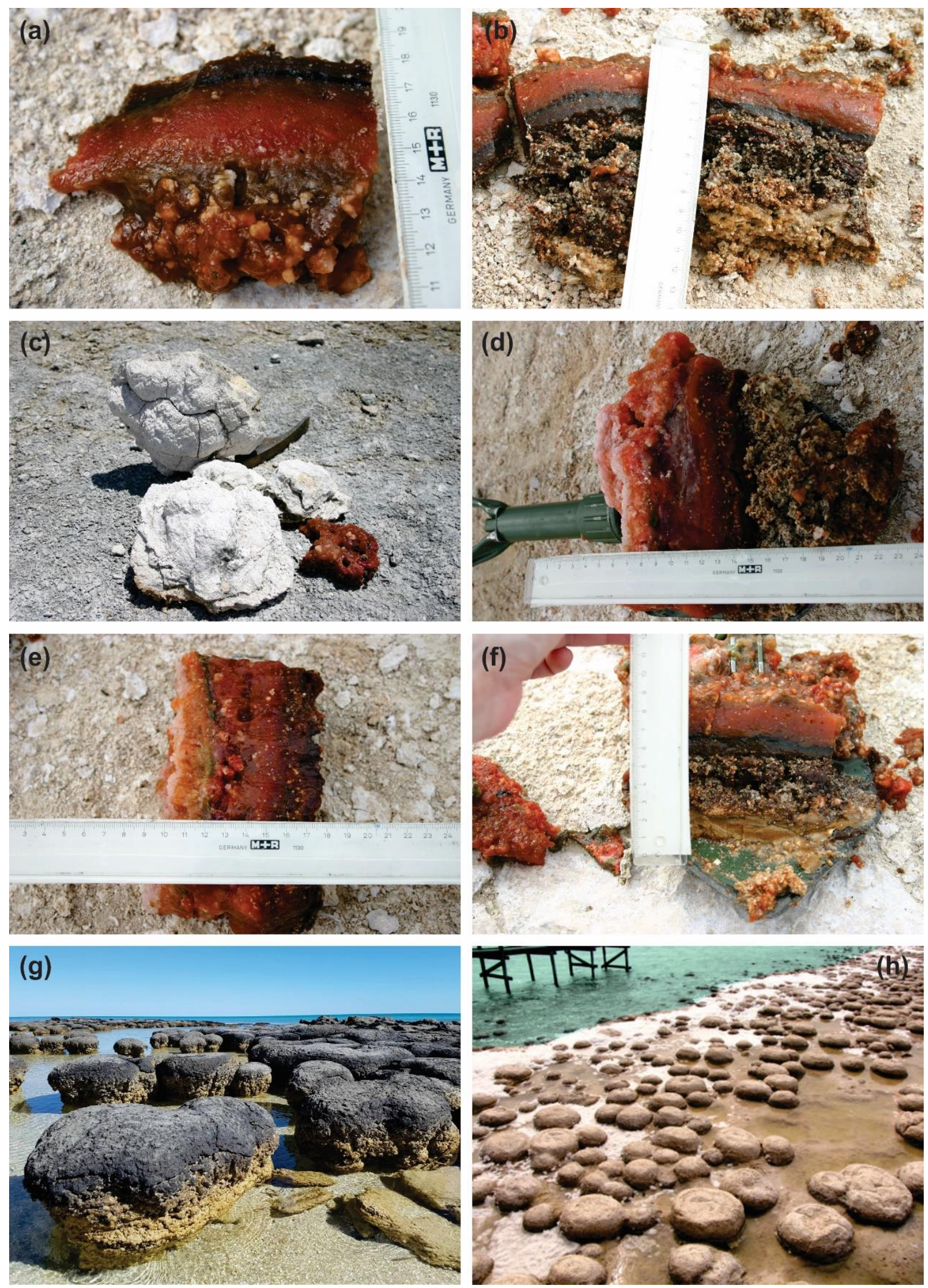

Figure 1.1 Examples of microbial mats and ancient microbialites: (a)-(f) a variety of colourful microbial mats collected from the atoll of Kiritimati (contributions from the department of Geobiology, University of Göttingen); (g) Stromatolites from Shark Bay, Western Australia (modified from sharkbay visit.com.au); (h) Thrombolites from Lake Clifton, Western Australia (modified from lifeonperth.com). 
Microbial mats present vertically laminated structures and are composed of functional groups of microbial communities controlling the organic matter (OM) turnover within the mats (Des Marais, 2003; van den Ende and van Gemerden, 1994). The major groups comprise cyanobacteria, colorless sulfur bacteria, purple sulfur bacteria and sulfate-reducing bacteria as well as eukaryotic organisms and archaea (Schneider et al., 2013; van Gemerden, 1993). Photosynthesis, coupling light energy to $\mathrm{CO}_{2}$ fixation and leading to accumulation of biomass, is thought to be the primary driving force of microbial mats. Subsequently, sulfatereducing bacteria, decomposing the primary production of cyanobacteria, produce sulfide by the dissimilatory reduction of sulfate. The resulting sulfide can be re-oxidized to sulfate again by colorless and purple sulfur bacteria. Moreover, several other microbes might also be involved in the OM turnover in the mat, such as chemotrophic bacteria and archaea (Blumenberg, Thiel and Reitner, 2015; Reitner and Thiel, 2011; Spring et al., 2015). In this respect, microbial mats are great models to investigate biogeochemical processes on a small $(\mathrm{mm}-\mathrm{cm}) \mathrm{scale}$, since a large variety of microorganisms cooperate and interact in complex metabolic pathways that influence the cycles of major elements within the mats (Seckbach and Oren, 2010). Under certain conditions, part of the microbial mat biomass might be transformed and preserved within mineral precipitates (commonly carbonate) that lead to the mineralization of the mat (i.e., microbialite).

The term "Microbialite" was introduced by Burne and Moore (1987), who characterized it as 'organosedimentary deposits that have accreted as a result of benthic microbial communities trapping and binding sediment and/or forming the locus of mineral precipitation'. A number of studies have demonstrated that several factors are involved in the carbonate precipitation within the mats, but the extracellular polymeric substances (EPS) secreted by the microbes are one of the most crucial controls of that process (Arp, Reimer and Reitner, 1999; Arp, Reimer and Reitner, 2001; Dupraz et al., 2009; Dupraz and Visscher, 2005; Reitner, 1993). EPS consist of polysaccharides, proteins, nucleic acids, lipids and humic substances (Nielsen, Jahn and Palmgren, 1997). In most cases, EPS accumulate outside the cells, and function as preventing desiccation, retaining essential nutrients as well as protecting against UV radiation (Decho, 1990; Decho, 2000). EPS contains negativelycharged acidic groups (e.g., carboxyl, amine, hydroxyl groups), and hence EPS are able to bind a large amount of divalent free cations (e.g. $\mathrm{Ca}^{2+}$ and $\mathrm{Mg}^{2+}$, Braissant et al., 2007). This binding capacity might inhibit mineral precipitation by depleting the positive ions from the surrounding microenvironment. Therefore, microbial carbonate formation is controlled by the 
inhibitory function of acidic EPS. Carbonate precipitates are formed, if the local hydrochemical conditions are suitable (e.g. alkalinity and saturation state; Arp et al., 2001), when EPS release the previously bound cations, as they are often degraded in the deeper part of the mat (Arp et al., 2012; Arp, Reimer and Reitner, 2003; Dupraz, Reid and Visscher, 2011). Consequently, EPS play an important role in the formation of microbialites as they influence the availability of cations and provide the location where the carbonate minerals nucleate and grow (Dupraz et al., 2004).

Microbialites can be generally classified into four types based on their mesostructure (structure visible with the naked eye, such as lamination, see Figure 1.1): stromatolites (laminated microbialites), thrombolites (clotted fabrics), leiolites (structureless micritic fabrics), and dendrolites (dendritic fabrics; Burne and Moore, 1987; Dupraz, Reid and Visscher, 2011; Dupraz and Strasser, 2002; Riding, 1991; Riding, 2000). Various microstructures may occur within these microbialites, including micritic, clotted, micropeloidal, microsparitic, agglutinated, and even sometimes including encrusting fossils and borings (Flügel and Munnecke, 2010).

Prior to the advent of vertical bioturbation at the Ediacaran-Cambrian transition ("agronomic revolution" or "substrate revolution"; Bottjer, Hagadorn and Dornbos, 2000, Seilacher, 1999; Seilacher and Pflüger, 1994), microbial mats have been proposed to be the predominant life forms in Archean and Proterozoic oceans, distinguished from the Phanerozoic, which is typified by the flourishment of metazoans and less common benthic microbial mats (Grotzinger and Knoll, 1999; Riding, 2011). Eukaryotic steranes are particularly absent or occur in very low concentrations in Precambrian sedimentary rocks. This phenomenon may be explained by minor eukaryotic contributions to primary production (Anbar and Knoll, 2002; Blumenberg, Thiel and Reitner, 2015; Knoll et al., 2007), and/or thermal destruction (Summons, Powell and Boreham, 1988a). Another potential explanation would be that eukaryote-derived lipids might have suffered from a preservation bias due to the ubiquitous benthic microbial mats ("mat-seal effect", Pawlowska, Butterfield and Brocks, 2013). Thereby, organic matter produced by heterotrophic microorganisms in the deeper mat layers would be preferentially preserved, while the signals from the upper layers get suppressed (chapter 3 of this thesis). This scenario is distinct from the situation in the Phanerozoic, in which OM from primary producers is more quickly transported to the sediment through sinking aggregates (e.g. faecal pellets), and lacking alteration in microbial mats (Close, Bovee and Pearson, 2011; Fowler and Knauer, 1986). As a result, marine 
biogeochemical cycles were reorganized. For instance, $\mathrm{O}_{2}$ was largely retained in surface waters and hardly transported to the deeper ocean in the Proterozoic. Due to the slow sinking, $\mathrm{OM}$ was greatly reworked by heterotrophic organisms resulting in the depletion of $\mathrm{O}_{2}$ on the sea floor. On the other hand, in the Phanerozoic, the rapid transportation of OM significantly decreased the consumption of $\mathrm{O}_{2}$ in surface waters, and thus prompted its evasion to the atmosphere as well as its delivery to the deep sea. Hence, the biological redox level moved from surface waters to the bottom sediments, and considerable quantities of organic carbon were transported to the sea floor and sequestered by the remineralization. Ultimately, the deep ocean was ventilated, allowing the start of radiation of metazoan (Logan et al., 1995).

\subsection{Biosignatures}

Biosignatures are traces of organisms that provide scientific evidence of past or present life. They may hold characteristic information such as the fundamental structure and biosynthetic pathways of their parent organisms, and the contemporary surrounding environmental conditions. In general, biosignatures could be derived from the major features of living organisms, including nucleic acids and membrane lipids, physical structures such as skeletons and shells as well as synthetic metabolisms and the associated products. Possible biosignatures could be: 1) genetic and biochemical substances (i.e., DNA and protein), 2) morphological fossils (i.e., body fossils), 3) organic molecular fossils (i.e., biomarkers), 4) elemental isotopic compositions, 5) mineral precipitates (i.e., microbial carbonate microfacies). This thesis will particularly focus on molecular biosignatures and on the associated microbial carbonate microfacies observed in the studied microbial mats.

\subsubsection{Morphological biosignatures}

Fossils are the remnants of the physical structure of ancient organisms or the traces of activity of such organisms, which can be divided in two types: body fossils and trace fossils (Figure 1.2). Body fossils are the most common type of fossils found across the world, and include the remains of hard parts of dead animals, plants and other life forms (i.e., teeth, bones and shells). 

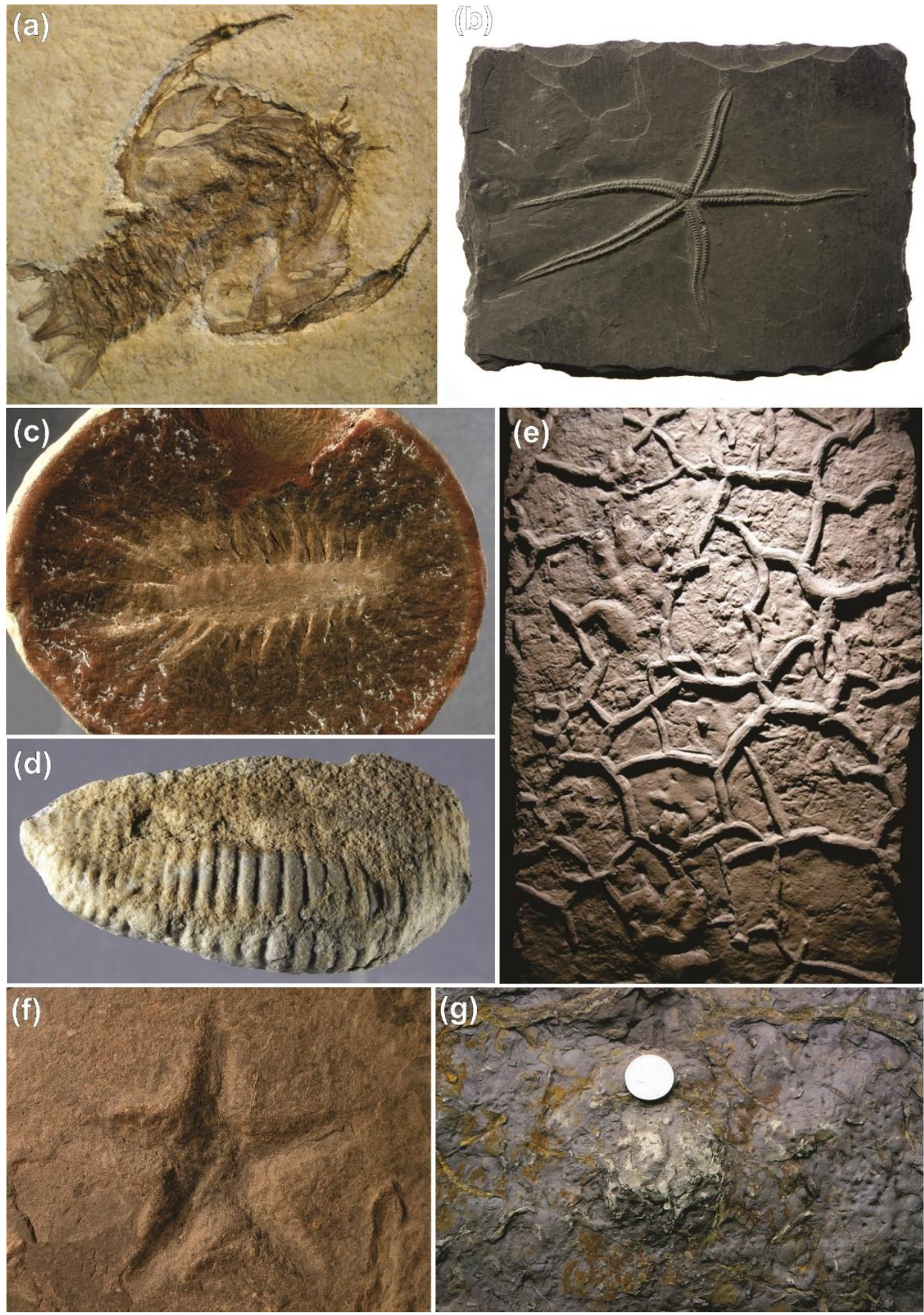

Figure 1.2 Fossil examples: (a) Body fossil of crabs from Late Triassic, found in Solnhofen lithographic limestone, Germany; (b) Body fossil of sea star from lower Devonian, found in Bundenbach Hunsrück Slate, Germany; (c) Body fossil of worm Polychaete from Carboniferous, found in Mazon Creek deposits, Illinois, USA; (d) Body fossil of Ernietta from Ediacara, found in Namibia; (e) Trace fossil footprints of Chirotherium, found in Triassic sandstone; (f) Trace fossil burrow of sea star, Asteriacites, from Devonian of northeastern Ohio, USA (modified from Wikipedia); (g) Trace fossil of Trilobite, found in Georgia, USA. Subfigures (a) to (d) are modified from the collections of Department of Geobiology, University of Göttingen; subfigures (e) and (g) are modified from (Seilacher 2007). 
Microfossils are another kind of body fossils, which show generally small size and are often observed with microscopes. Unlike other kinds of body fossils (i.e., invertebrate fossils, palynomorphs, fossil plants), microfossils are not grouped based on the phylogenetic relationships, but only due to their small size and method of study. As a result, microfossils comprise heterogeneous fossil remains, including bacteria, foraminifera, diatoms and pollen.

Trace fossils are the indirect signs of past life that provide evidence of the occurrence of those organisms (i.e., footprints, burrows and trails).

As silent witnesses to Earth's life, fossils have the potential to provide valuable insights, not only into the climates and ecosystems in which they once lived, but also into the evolution of organisms through their sequential occurrence during the geologic history of Earth (Bykova et al., 2017; Bolliger et al., 2012; Canfield, Poulton and Narbonne, 2007; Chen et al., 2014; Johnston et al., 2013; Porter and Knoll, 2000; Sahoo et al., 2012).

\subsubsection{Microfacies}

Microfacies denote all the sedimentological and paleontological data that can be described and classified from thin-sections, peels, polished slabs or rock samples (Flügel and Munnecke, 2010).

Microfacies include fossils and a variety of sedimentary minerals deposited from the natural environment (i.e., carbonate, silicate, gypsum and phosphate), or during burial and diagenesis. Since carbonate minerals are the primary components observed within the studied modern microbial mats (Kiritimati, Central Pacific), the following description about microfacies will be particularly concentrating on the microbial carbonate microfacies (see Figure 1.3), using the classification proposed by (Flügel and Munnecke, 2010).

Peloids, exhibiting a general size of 20-60 $\mu \mathrm{m}$, are one of the most common microfabric components of modern and ancient microbialites, and they are composed of fine-grained granular micritic aggregates, often irregularly distributed (Reitner, 1993). They are generally interpreted as autochthonous, benthic and microbial in origin (Dupraz and Strasser, 1999; Monty, 1976; Riding, 2002b; Riding, 2000; Perri, Tucker and Spadafora, 2012). Microscopically, some peloids possess fossil bacterial clumps constituting their nuclei and showing a diameter of 10-20 $\mu \mathrm{m}$ (Reitner, 1993). Chafetz (1986) and Riding (2002a) suggested that peloids may be calcified aggregates similar to fossilized bacterial colonies in Phanerozoic biofilms. Other hypotheses have regarded the formation of peloidal carbonate 
precipitates as related to the metabolic activities of bacteria (Dupraz et al., 2004; Riding and Tomas, 2006; Spadafora et al., 2010). Peloidal fabrics might form in situ during very early diagenesis, as a result of degradation and mineralization of organic matter (i.e., EPS) mediated by heterotrophic bacteria (Reitner, 1993; Reitner et al., 1995). The spaces between peloids are successively infilled by the precipitation of microsparite, when the organic matter is removed (Perri, Tucker and Spadafora, 2012; Spadafora et al., 2010; Riding and Tomas, 2006).
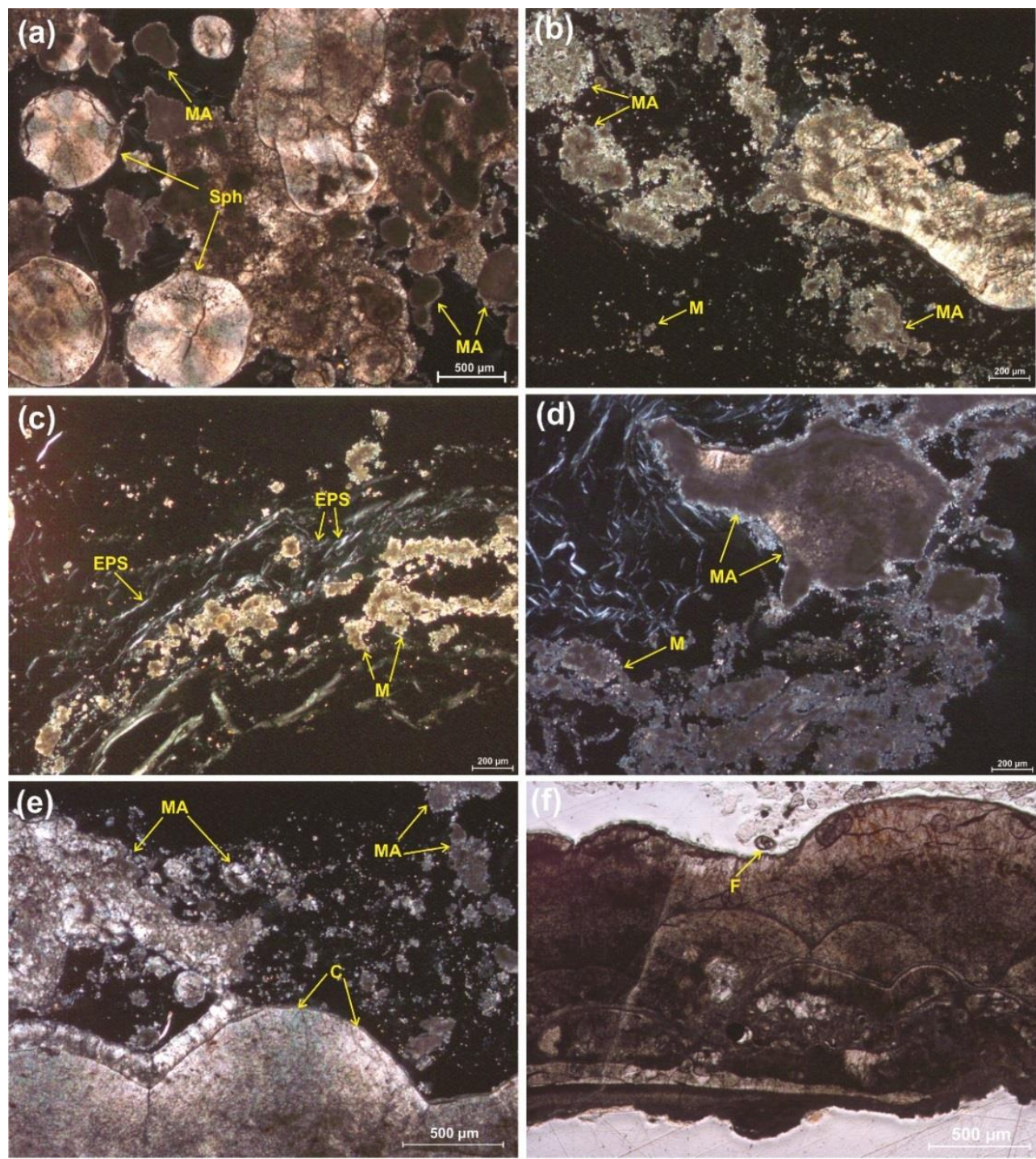

Figure 1.3 Microfacies examples in Kiritimati microbial mat: (a) Transmitted light photomicrograph of subspherical aragonite particles (Sph) with radially-oriented internal structure, within abundant micritic aggregates (MA); (b) Transmitted light photomicrograph of micritic aggregates (MA), composed of micropeloids. Note also isolated micropeloids $(\mathrm{M})$ in an early stage of development, before they evolve into micritic aggregates; (c) Transmitted light photomicrograph of micropeloids (M) within a matrix of extracellular polymeric substances (EPS); (d) Cross-polarized light photomicrograph of a clotted fabric consisting of large micritic aggregates (MA) and smaller micropeloidal micrite (M); (e) Cross-polarized light photomicrograph of micritic aggregates (MA) over the mineral crust (C); (f) partial view of mineral crust layer with abundant remains of filamentous and bacteria entrapped therein. Note also foraminifera $(\mathrm{F})$ over the mineral crust. 
Other common and significant components of microbialite microfacies are clotted fabrics, consisting of densely packed, variable sized peloids amalgamated in larger, globular and irregular micritic clots. They often occur within a microspar, micrite or spar matrix and are widespread in stromatolites and thrombolites (Flügel and Munnecke, 2010). Earlier works reported the potential origins of micritic clotted fabric, for instance, as recrystallization of carbonate mud and peloidal micrite (Bathurst, 1970), as diagenetic amalgamation of precipitated peloids (Reid, 1987), and as diagenetic modification of algal debris (Coniglio and James, 1985), as well as in situ production of calcified mats of benthic coccoid cyanobacteria (Kazmierczak et al., 1996), which is currently the most commonly accepted hypothesis.

Spherulites (see Figure 1.3), composed of radially-oriented carbonate precipitates, typically $\mu \mathrm{m}$ scale in diameter with a cloudy micrite core, occur in many different settings (Flügel and Munnecke, 2010) and they are commonly formed in association with microbial EPS (e.g. Braissant et al., 2003). The formation of spherulites within the sediment is mainly controlled by the $\mathrm{CaCO}_{3}$ supersaturation attributed to the release of $\mathrm{CO}_{2}$ during the decay of organic matter and microbial activities (i.e., sulphate reduction, Flügel and Munnecke, 2010).

Fossil cyanobacterial filaments are also common components of microbialite microfacies. They result from complex bacterially-driven mineral precipitation processes within and upon the sheath surrounding the cell wall. This calcification process is possibly dependent on the sheath character, environmental conditions and nucleation of $\mathrm{CaCO}_{3}$ within the sheath (Arp, Reimer and Reitner, 2001). The calcified sheath surfaces facilitate the fossilization of microbes (calcimicrobes), and thus their preservation (Flügel and Munnecke, 2010). Cyanobacteria calcification occurs ubiquitous in marine environment during Palaeozoic and Mesozoic Eras, which may reflect temporal changes in seawater chemistry (Arp, Reimer and Reitner, 2001). The records of well-calcified cyanobacteria first appear in the PrecambrianCambrian boundary (Riding, 1991).

The carbonate microfacies in Kiritimati microbial mats primarily include micropeloidal aggregates and subspherical particles (see Figure 1.3) with fibrous-radial structures. SuarezGonzalez et al. (2017) described that the micropeloidal aggregates are composed of the $\mu \mathrm{m}$ scale bundles of aragonite needles and dumbbells, which occur either individually, twinned or forming small $(10-30 \mu \mathrm{m})$ spheres with radial structure (i.e. peloids). The subspherical particles are internally formed by fibrous radially arranged long and thin aragonite crystals, and hence can be classified as spherulites. However, since they often grow around a micritic 
nucleus and their cortex is laminated (with micritic laminae which alternate with the radial crystalline laminae), some of them could be classified as ooids (Suarez-Gonzalez et al., 2017). These micritic laminae within the ooid-like spherulites are typically very thin, but locally reach c. $50 \mu \mathrm{m}$. Another peculiar structure observed only in the microbial mat microfacies of Kiritimati Lake 2, is a thin mineral crust composed of a $\mu \mathrm{m}$-scale superposition of radialfibrous aragonite botryoids that encase very abundant filamentous microbes and diatoms. More detailed information will be found in Chapter 4.

\subsubsection{Biomarker}

The term biological markers or "biomarkers" refers to organic compounds (particularly lipids) that are taxonomically specific for some certain groups of once-living organisms and can be helpful to reconstruct ancient ecosystems and the concurrent environmental conditions (Brocks, 2005; Peters, Walters and Moldowan, 2005a; Volkman, 2006). Biomarkers are molecular fossils consisting of carbon and hydrogen, and often oxygen, and may also contain other elements such as nitrogen, phosphorous and sulfur. Biomarkers are often preserved in two fractions of organic matter that retained in fossil samples. One fraction called bitumen which is soluble in organic solvents; while the other is kerogen that is insoluble in organic solvents, acids and bases (Dow, 1977; Vandenbroucke and Largeau, 2007). For this thesis, bitumen is further subdivided in free-lipids (extracted before decalcification) and bound-lipids (those tightly bound to the mineral precipitates, extracted after decalcification).

Biomarkers are derived from functional biomolecules that experience alteration by diagenesis (biological and chemical processes) during deep burial over geologic time. Most functional biomolecules lose all of their functional groups and undergo structural rearrangement via cracking and isomerization reactions. These processes create a variety of homologues and stereo- and structural isomers. The resulting products possess geologicallystable structures that are highly resistant to thermal- and biodegradation, termed as geolipids. As a consequence, they can be preserved in sediments, sedimentary rocks and crude oils over billions of years (Brocks, 2005).

Unlike the body fossils, biomarker conservation is determined by different taphonomic rules, and in addition, many organisms did not produce preservable cell walls or skeletons to against degradation (i.e., soft, single-celled organisms). Therefore, organic biomarkers are considered to provide complementary view of past ecosystems independent from the body fossil records (Brocks et al., 2016; Knoll et al., 2007). Given these characteristic features of 
biomarkers and their analyzable natural samples with routine techniques, they are useful tools to trace the information of their biogenic precursors and to reveal the depositional environment in the past (Peters, Walters and Moldowan, 2005a; Brocks and Summons, 2004; Summons et al., 2008). Many investigations have successfully unveiled the earlier environmental settings by assessing the biomarker signatures buried at the time of deposition. For instance, Summons and Powell (1986) demonstrated anaerobic conditions in the water column of Palaeozoic seas; warmer and higher-elevation were reconstructed in northern Sierra Nevada during the early Eocene (Hren et al., 2010); hypersaline deposition occurred in evaporitic environment of the Dead Sea Basin for the Miocene/Pliocene (Grice et al., 1998). In addition to paleoenvironment, organic biomarkers also encode ancient biodiversity and evolution of early life in the Earth's history, for example, the evidence of the early rise of eukaryotes reported by Brocks et al. (1999) and the increasing role of algae as drivers for the radiation of the eumetazoan animals (Brocks et al., 2017). Other studies also used biomarkers to reconstruct the first appearance of major groups of organisms, as demonstrated by McCaffrey et al. (1994a); Moldowan et al. (1994); Moldowan and Talyzina (1998) and Brocks et al. (2005). Moreover, biomarkers have recorded the global cooling event (Liu et al., 2009) and the reorganization of biogeochemical cycles (Logan et al., 1995), and applied to the discovery of new petroleum reservoirs (Peters, Walters and Moldowan, 2005b). The realm of biomarker research is relatively young (i.e., Treibs, 1936) and present extensive prospects. Some examples for representative lipid biomarkers are given below.

\subsubsection{Hydrocarbons}

Hydrocarbons are compounds that only contain carbon and hydrogen, consisting of multiple chemical structures formed by degradation of lipids.

\ Straight-chain alkanes (n-alkanes) are acyclic saturated hydrocarbons with the absence of branches (i.e., methyl, ethyl), showing general chemical formula of $\mathrm{C}_{n} \mathrm{H}_{2 n+2}$ such as hexadecane $\left(\mathrm{C}_{16} \mathrm{H}_{34}\right.$; see Figure 1.4), which are ubiquitous in sedimentary rocks of any geological age, and their potential biogenic precursors can be found in virtually all extant organisms (Brocks and Summons, 2004). The biologically derived $n$-alkanes often show an odd-to-even predominance, resulted from the decarboxylation (loss of - $\mathrm{COOH}$ ) of even numbered fatty acids (Peters, Walters and Moldowan, 2005b). As previously reported, shortchain length $n$-alkanes, particularly $n$ - $\mathrm{C}_{17}$, are usually considered to be derived from algae and photosynthetic bacteria (Han and Calvin, 1969; Cranwell, Eglinton and Robinson, 1987; 
Meyers, 2003), while $n$-alkanes with 23 and 25 carbon atoms reveal an origin of submerged/floating aquatic macrophytes (Ficken et al., 2000; Nichols et al., 2006; Sachse, Radke and Gleixner, 2004). The long-chain homologs in the range of $n-\mathrm{C}_{27}$ to $n-\mathrm{C}_{33}$ are commonly suggesting the organic inputs of epicuticular leaf waxes from higher land plants (Eglinton and Hamilton, 1967; Cranwell, Eglinton and Robinson, 1987). $n$-alkanes can be easily identified with gas chromatograph-mass spectrometry (GC-MS), and give characteristic mass spectra showing series of $\mathrm{C}_{\mathrm{n}} \mathrm{H}_{2 \mathrm{n}+1}$ ions that decrease in abundance with increasing $\mathrm{m} / \mathrm{z}$ value. The major mass fragmentations are visualized as $\mathrm{m} / \mathrm{z} 57,71$, or 85 as well as the mass molecular weight $\mathrm{M}^{+}$and $\mathrm{M}^{+}-15$ ions.

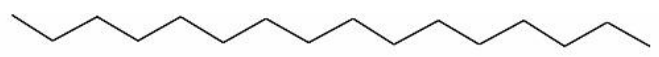

(1) Hexadecane $\left(\mathrm{C}_{16} \mathrm{H}_{34}\right)$

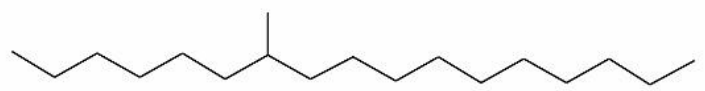

(2) 7-methylheptadecane $\left(\mathrm{C}_{18} \mathrm{H}_{38}\right)$

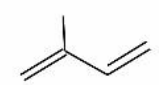

(3) Isoprene $\left(\mathrm{C}_{5} \mathrm{H}_{8}\right)$

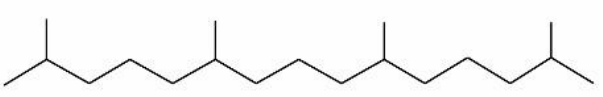

(4) Pristane $\left(\mathrm{C}_{19} \mathrm{H}_{40}\right)$

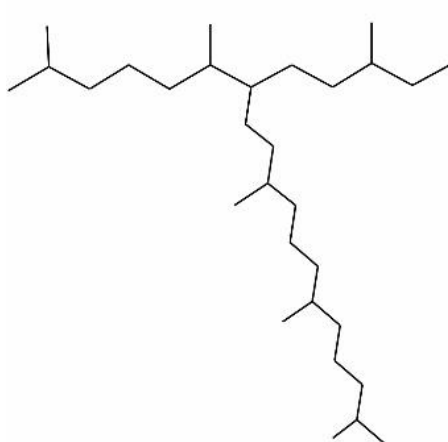<smiles>CCC(C)CCCC(C)CCCC(C)CCCC(C)C</smiles>

(5) Phytane $\left(\mathrm{C}_{20} \mathrm{H}_{42}\right)$<smiles>CC(C)CCCC(C)CCCCC(C)CCCC(C)C</smiles>

(6) Crocetane $\left(\mathrm{C}_{20} \mathrm{H}_{42}\right)$<smiles>CC(C)CCCC(C)CCCCC(C)CCCC(C)CCCC(C)C</smiles>

(8) $\mathrm{HBI}\left(\mathrm{C}_{30} \mathrm{H}_{62}\right)$

(7) 2,6,10,15,19-Pentamethylicosane (PMI, $\mathrm{C}_{25} \mathrm{H}_{52}$ )<smiles>CCC(C)CCCC(C)CCCC(C)CCCC(C)CCCC(C)CCCC(C)CCCC(C)CCCC(C)CC</smiles>

(9) Biphytane $\left(\mathrm{C}_{40} \mathrm{H}_{82}\right)$

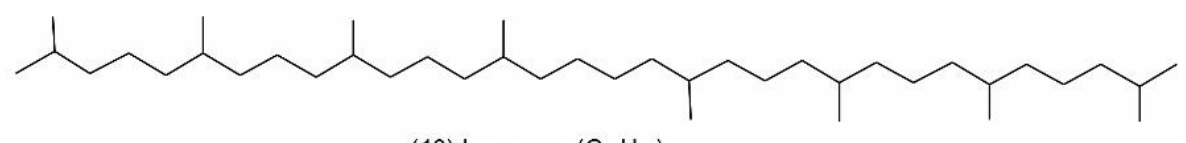

(10) Lycopane $\left(\mathrm{C}_{40} \mathrm{H}_{82}\right)$

Figure 1.4 Examples of hydrocarbons showing the carbon skeletons: (1) Hexadecane $\left(\mathrm{C}_{16} \mathrm{H}_{34}\right)$; (2) 7methylheptadecane $\left(\mathrm{C}_{18} \mathrm{H}_{38}\right)$; (3) Isoprene $\left(\mathrm{C}_{5} \mathrm{H}_{8}\right)$; (4) Pristane $\left(\mathrm{C}_{19} \mathrm{H}_{40}\right)$; (5) Phytane $\left(\mathrm{C}_{20} \mathrm{H}_{42}\right)$; (6) Crocetane $\left(\mathrm{C}_{20} \mathrm{H}_{42}\right)$; (7) 2,6,10,15,19-Pentamethylicosane (PMI, $\left.\mathrm{C}_{25} \mathrm{H}_{52}\right)$; (8) HBI $\left(\mathrm{C}_{30} \mathrm{H}_{62}\right)$; (9) Biphytane $\left(\mathrm{C}_{40} \mathrm{H}_{82}\right)$; (10) Lycopane $\left(\mathrm{C}_{40} \mathrm{H}_{82}\right)$. 
A Branched acyclic alkanes are acyclic saturated hydrocarbons wherein the carbon backbone splits off in two or more directions. Simple branched alkanes such as 6-, 7- and 8methylheptadecane $\left(\mathrm{C}_{18} \mathrm{H}_{38}\right.$; see Figure 1.4 $)$ are universally biosynthesized by cyanobacteria (Coates et al., 2014; Han and Calvin, 1969; Fehler and Light, 2002). Series of longer midchain monomethyl alkanes have been reported in Precambrian sedimentary rocks and crude oils (Kenig et al., 1995; Kissin, 1987; Höld et al., 1999; Shiea, Brassel and Ward, 1991; Summons et al., 1988b; Fowler and Douglas, 1987; Summons, 1987), indicating either direct biological contributions (Höld et al., 1999; Shiea, Brassell and Ward, 1990) or diagenetic products generated by the transformation of functionalized lipid such as carboxylic acids (Summons, Powell and Boreham, 1988a; Thiel et al., 1999a).

Other branched alkanes included here are isoprenoids, which are hydrocarbons composed of polymerized isoprene units $\left(\mathrm{C}_{5} \mathrm{H}_{12}\right.$; see Figure 1.4; an arrangement of five carbon atoms that forms the building blocks of many biomarkers such as triterpanes and steranes). Isoprene units can be linked together in 1) regular way (tail to head, i.e., pristane $\mathrm{C}_{19} \mathrm{H}_{40}$ and phytane $\mathrm{C}_{20} \mathrm{H}_{42}$; see Figure 1.4); and 2) irregular way (tail to tail, i.e., crocetane $\mathrm{C}_{20} \mathrm{H}_{42}$; and head to head, i.e., biphytane $\mathrm{C}_{40} \mathrm{H}_{82}$; see Figure 1.4). Isoprenoids comprise various compounds, and typical acyclic isoprenoids include pristane and phytane, which are major components in many ancient sediments and crude oils. In addition, pristane and phytane have been widely assumed to be diagenetic products of the phytyl side chain of chlorophyll a in phototrophic organisms and bacteriochlorophyll $\mathrm{a}$ and $\mathrm{b}$ in purple sulfur bacteria (Brooks, Gould and Smith, 1969; Powell and McKirdy, 1973; ten Haven et al., 1987; Wang et al., 2008), and other potentiall sources are also suggested such as tocopherols (Goossens et al., 1984) and archaea (Chappe, Albrecht and Michaelis, 1982). Briefly, anoxic conditions facilitate cleavage of the phytyl side chain to yield phytol that experience reduction to generate phytane, while oxic conditions promote the formation of pristane by oxidation and decarboxylation of phytol. The ratio of pristane/phytane $(\mathrm{Pr} / \mathrm{Ph})$ is therefore interpreted as a proxy for the depositional redox conditions (Didyk et al., 1978). For instance, high values of $\mathrm{Pr} / \mathrm{Ph}(>3)$ suggest organic matter inputs under oxic conditions, whereas low ratios $(<0.8)$ are typical for anoxic, normally hypersaline or carbonate environments (Peters, Walters and Moldowan, 2005b). Crocetane $\left(\mathrm{C}_{20} \mathrm{H}_{42}\right.$, an isomer of phytane $)$ and PMI $\left(\mathrm{C}_{25} \mathrm{H}_{52}\right.$; see Figure 1.4) are both tail-to-tail linked isoprenoid hydrocarbons, and they show origins from methanogenic and methanotrophic archaea as well as sulfate-reducing bacteria that are typically depleted in ${ }^{13} \mathrm{C}$ (Hinrichs et al., 2000; Pancost et al., 2000a; Thiel et al., 1999b; 
Peters, Walters and Moldowan, 2005b). Further, lycopane $\left(\mathrm{C}_{40} \mathrm{H}_{82}\right.$; see Figure 1.4 $)$, also presenting a tail-to-tail isoprenoid linkage, is particularly abundant in ancient sediments which were deposited under anoxic environmental conditions (Kimble et al., 1974; Kohnen et al., 1992; Schouten et al., 1997; Freeman et al., 1990). Several investigations have suggested the potential origins of lycopane, such as methanogenic archaea (Brassell et al., 1981), photoautotrophic microorganisms (Wakeham et al., 1993) as well as marine phytoplankton (McCaffrey, Farrington and Repeta, 1991). In addition, Sinninghe Damsté et al. (2003) reported that long-chain $n$-alkanes are more stable and less prone to post-depositional degradation relative to lycopane, and thus the lycopane $/ n-\mathrm{C}_{31}$ ratio may be used as a proxy to evaluate palaeoxicity during sedimentary processes, with higher values as indicative of low oxygen concentrations. Biphytane $\left(\mathrm{C}_{40} \mathrm{H}_{82}\right)$, as an isomer of lycopane, show irregular head-tohead linkages and commonly bound to ether-bonds that are typical biomarkers from diglycerol tetraether lipids in membranes of Archaea (Volkman and Maxwell, 1986; Kates, 1997). These ether-bound extended $\mathrm{C}_{40}$ isoprenoids have been detected in a variety of ancient source-rock settings, including marine marls and hypersaline evaporites (Schouten et al., 1998a; Schouten et al., 2000b) as well as recent sediments such as hydrothermal springs and surface ocean waters (Hoefs et al., 1997) and peat bogs (Pancost et al., 2000b), and their possible biogenic precursors could be methanogenic archaea (Schouten, Hopmans and Sinninghe Damsté, 2013; Schouten et al., 1998a). Other common isoprenoidal compounds are highly branched isoprenoid (HBI; see Figure 1.4), which are used as specific molecular fossils for diatoms, and can be used as age-diagnostic biomarkers (Sinninghe Damsté et al., 2004).

For the identification of these isoprenoids, branched alkanes produce similar spectra to those of $n$-alkanes, but show more intense fragmentations with the branching position that is easily visualized. In general, isoprenoids give characteristic ions at $\mathrm{m} / \mathrm{z} 113,169,183,197$, 253 and with help of other mass fragments deduced from different connections of isoprene units (i.e., head-to-head and tail-to-tail linkages). Combined with some co-elution cases, i.e., pristane is often co-eluting with $n \mathrm{C}_{17}$-alkanes, phytane co-elutes with $n \mathrm{C}_{18}$ and $\mathrm{PMI}$ with $n \mathrm{C}_{23}$-alkanes, while biphytane co-elute with $n \mathrm{C}_{35}$, and lycopane elutes near $n \mathrm{C}_{34-} n \mathrm{C}_{35^{-}}$ alkanes, and hence they can be readily identified. 


\subsubsection{Fatty acids}

Fatty acids are carboxylic acids with saturated or unsaturated hydrocarbon chains, generally ranging between 4 and 28 of carbon atoms. They are vital components of phospholipids and glycolipids, which are the primary constituents of lipid membranes in eubacteria and eukarya.

A Straight-chain fatty acids (saturated and unsaturated) occur ubiquitously in organic sediments of geological time, and have been used as indicators of sedimentary source materials. For instance, the fatty acids (i.e., $>\mathrm{C}_{20}$ ) often showing a strong even-over-odd predominance are thought to be inputs of higher plants, while those in the range of $\mathrm{C}_{12}-\mathrm{C}_{18}$ have been attributed to aquatic (algal and microbial) source organisms (Brassell et al., 1980; Cranwell, 1982). Of the straight-chain fatty acids, $\mathrm{C}_{16: 0}$ (palmitic acid; see Figure 1.5) and $\mathrm{C}_{18: 0}$ (stearic acid; see Figure 1.5), together with their mono-unsaturated analogues, are often predominant (Kaneda, 1991).

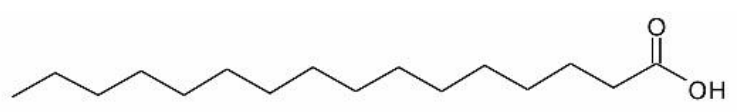

(1) Palmitic acid $\left(\mathrm{C}_{16} \mathrm{H}_{32} \mathrm{O}_{2}\right)$

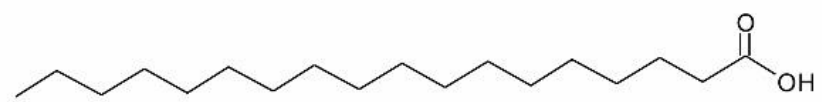

(2) Stearic acid $\left(\mathrm{C}_{18} \mathrm{H}_{36} \mathrm{O}_{2}\right)$<smiles>CC(C)CCCCCCCCCCCC(=O)O</smiles>

(3) iso- $\mathrm{C}_{15: 0}\left(\mathrm{C}_{15} \mathrm{H}_{30} \mathrm{O}_{2}\right)$<smiles>CCC(C)CCCCCCCCCCC(=O)O</smiles>

(4) anteiso- $\mathrm{C}_{15: 0}\left(\mathrm{C}_{15} \mathrm{H}_{30} \mathrm{O}_{2}\right)$<smiles>CC(C)CCCCCCCCCCCCCC(=O)O</smiles>

(5) iso- $\mathrm{C}_{17: 0}\left(\mathrm{C}_{17} \mathrm{H}_{34} \mathrm{O}_{2}\right)$<smiles>CCC(C)CCCCCCCCCCCCC(=O)O</smiles>

(6) anteiso- $\mathrm{C}_{17: 0}\left(\mathrm{C}_{17} \mathrm{H}_{34} \mathrm{O}_{2}\right)$<smiles>O=C(O)CCCCCCCCCCCCCCCCCCC(=O)O</smiles>

Figure 1.5 Examples of fatty acids showing the carbon skeletons: (1) Palmitic acid $\left(\mathrm{C}_{16} \mathrm{H}_{32} \mathrm{O}_{2}\right)$; (2) Stearic acid $\left(\mathrm{C}_{18} \mathrm{H}_{36} \mathrm{O}_{2}\right)$; (3) iso- $\mathrm{C}_{15: 0}\left(\mathrm{C}_{15} \mathrm{H}_{30} \mathrm{O}_{2}\right)$; (4) anteiso- $\mathrm{C}_{15: 0}\left(\mathrm{C}_{15} \mathrm{H}_{30} \mathrm{O}_{2}\right)$; (5) iso- $\mathrm{C}_{17: 0}\left(\mathrm{C}_{17} \mathrm{H}_{34} \mathrm{O}_{2}\right)$; (6) anteiso- $\mathrm{C}_{17: 0}\left(\mathrm{C}_{17} \mathrm{H}_{34} \mathrm{O}_{2}\right) ;(7) \alpha, \omega$-dicarboxylic acid $\left(\mathrm{C}_{20} \mathrm{H}_{38} \mathrm{O}_{4}\right)$. 


\section{A Branched-chain fatty acids}

The iso- and anteiso- designation, as terminally branched type, represents fatty acids with a methyl group at the $\omega 2$ and $\omega 3$ position, respectively. These carboxylic acids such as $i s o$ - and anteiso- $\mathrm{C}_{15: 0}$ and $-\mathrm{C}_{17: 0}$ (see Figure 1.5), are considered to be primarily originated from sulfate-reducing bacteria (Dowling, Widdel and White, 1986; Heindel et al., 2010; Kaneda, 1991; Wakeham and Beier, 1991), although they have also been reported in other types of bacteria (Heindel et al., 2012; Romano et al., 2008).

Another type introduced here are mid-chain branched fatty acids, with a methyl group located at a mid-chain position. Examples are the suites of methyl- $\mathrm{C}_{14}$ to methyl- $\mathrm{C}_{24}$ (i.e., 10$\mathrm{C}_{14: 0}$ and 9- $\mathrm{C}_{24: 0}$ ), which are probably produced by heterotrophic bacteria living in symbiosis with demosponges. In addition, mid-chain branched fatty acids could be the precursors for the mid-chain branched alkanes preserved in ancient sediments and oils (Thiel et al., 1999a).

$\Delta \alpha, \omega$-dicarboxylic acids ( $\alpha, \omega$-diacids; see an example of diacids in Figure 1.5) refer to organic compounds containing two carboxyl functional groups (-COOH). Earlier studies suggested that $\alpha, \omega$-diacids have multiple biological sources, e.g., higher plants (Kolattukudy, 1980), sea-grass (Volkman et al., 1980), but can also be derived from in situ formation (via terminal oxidation of monoacids or other aliphatic moieties such as $n$-alkanes (Ishiwatari and Hanya, 1975; Johns and Onder, 1975) and $\omega$-hydroxy acids (Cranwell, 1978; Eglinton, Hunneman and Douraghi-Zadeh, 1968).

Fatty acids are typically studied as methyl esters, and give characteristic mass spectra showing a base peak at m/z 74 for saturated fatty acids, and an additional enhanced $\mathrm{m} / \mathrm{z} 55$ for unsaturated counterparts. For the branched iso-fatty acids, they display extra enriched $\mathrm{m} / \mathrm{z}$ $\mathrm{M}^{+}-43$, while anteiso- present relative higher abundance of $m / \mathrm{z} \mathrm{M}^{+}-57$ and $\mathrm{M}^{+}-29$ ions (Peters, Walters and Moldowan, 2005a).

\subsubsection{Hopanoids}

Hopanoids are omnipresent natural products occurring in diverse taxonomic groups of microbial communities, and they are indicative of bacterial origin (Ourisson and Albrecht, 1992; Ourisson, Albrecht and Rohmer, 1979; Rohmer, Bouvier-Nave and Ourisson, 1984). There is one exception, indicating their detection in plants of the genus Hopea (Pearson, 2014). They are cyclization products of squalene and show a structure of pentacyclic triterpenoids (four cyclohexane rings and one cyclopentane ring; see Figure 1.6, Kannenberg 
and Poralla, 1999; Sinninghe Damsté et al., 2017). Hopanoids are considered to be the functional analogue of sterols attributable to their similar structure and amphiphilic properties (Ourisson et al., 1987; Sáenz et al., 2015), and act as stabilizers in bacteria membranes, i.e., regulating and rigidifying functions comparable to that of sterols in the Eukarya (Summons et al., 1999; Rohmer, Bouvier and Guy, 1979; Rohmer, Dastillung and Ourisson, 1980).

In bacteria, the functional forms of hopanoids are bacteriohopanepolyols (BHP; see Figure 1.6), with a five carbon sugar-derived moiety bounded to the $C_{30}$ pentacyclic hopane skeleton. These BHPs might have the potential to survive in geological time, due to additional functionalized groups (i.e., $-\mathrm{OH}$ and amino acid) located at the side chain of the hopane skeleton. These polar moieties are easily cross-linking by sulfur compounds (Wakeham et al., 1995), and result in the formation of complex macromolecules and incorporation into kerogen (Dow, 1977; Vandenbroucke and Largeau, 2007). Apolar ringstructures of hopanoids may contain unsaturations or methyl groups at various positions. For instance, in the study of Summons et al. (1999), 2 $\alpha$-methylhopanes (see Figure 1.6) are possibly indicative of cyanobacterial inputs to sedimentary organic matter, while $3 \beta$-methylhopanes (see Figure 1.6) appear to be diagnostic for aerobic methanotrophs and methylotrophs as well as acetic acid bacteria (Blumenberg et al., 2012; Brocks, 2005; Summons and Jahnke, 1992; Zundel and Rohmer, 1985), or useful proxies for specific environmental conditions (Welander and Summons, 2012). Gammacerane, similar to hopanoids, was first identified as a $\mathrm{C}_{30}$ triterpane in the Green River shale with skeleton of five cyclohexane rings (Hills and Whitehead, 1966) and can be used as an indicator for water column stratification (Sinninghe Damsté et al., 1995). Its biological precursor, tetrahymanol, is primarily derived from bacterivorous ciliates when their diet is deprived of sterols (Lennart M. Maldegem et al., 2019; Sinninghe Damsté et al., 1995).

Earlier work reported that $\mathrm{O}_{2}$ is not required for hopanoid biosynthesis, but a large number of known hopanoid producers belong to aerobic or microaerophilic bacteria (Rohmer, Bouvier-Nave and Ourisson, 1984), i.e., cyanobacteria and $\alpha$ - and $\beta$-proteobacteria. On the other hand, several studies also proved biosynthesis of hopanoids could be conducted in anaerobic environments (Thiel et al., 1999b; Thiel et al., 2003; Pancost et al., 2000a). 


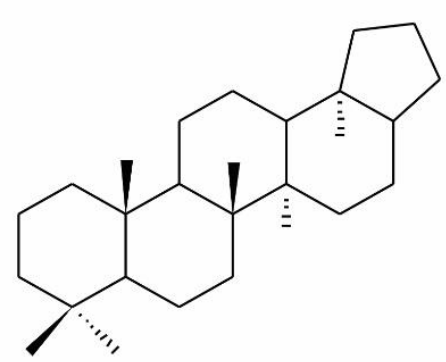

(1) Hopanoid ring structure

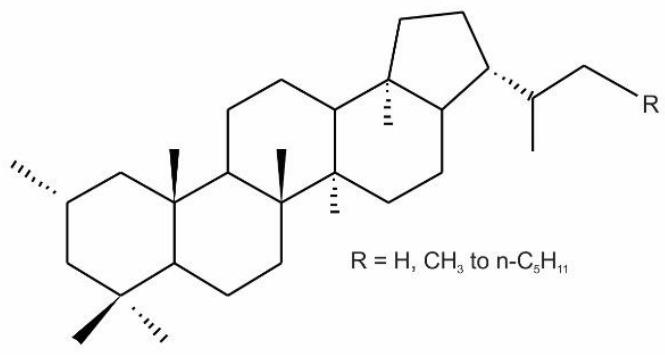

(3) $2 \alpha$-methylhopanes

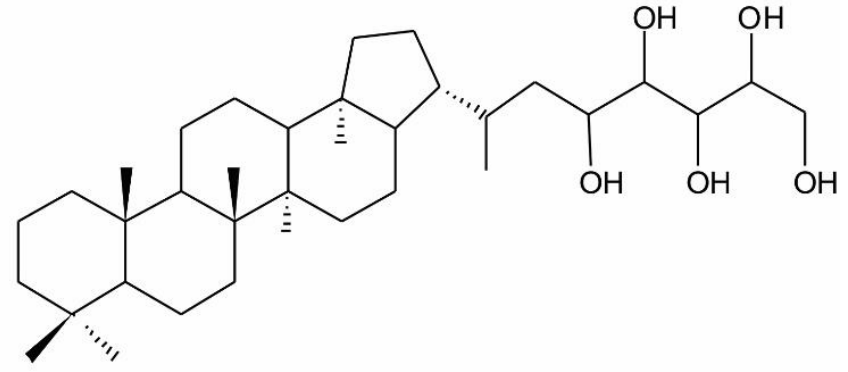

(2) Bacteriohopanepolyols (BHP)

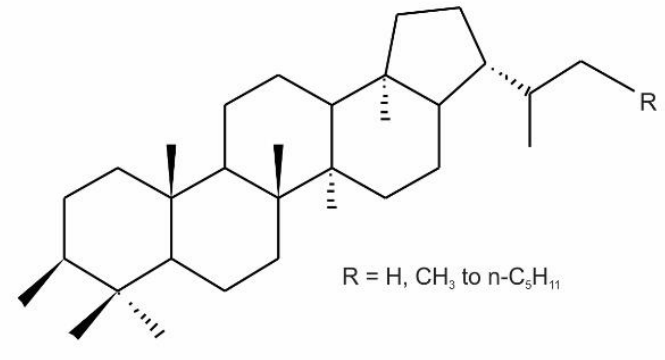

(4) 3ß-methylhopanes

Figure 1.6 Examples of hopanoids showing the carbon skeletons: (1) Hopanoid ring structure; (2)

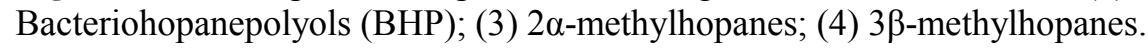

Further, due to advanced methodologies, most hopanoids (excluding intact hopanoids) can be nowadays directly identified by the routine techniques of GC-MS, and are usually characterized with the major mass fragmentograms of m/z 191, and additionally, m/z 177 for desmethylated hopanes or m/z 205 with an extra methyl group in A ring (Sessions et al., 2013; Volkman, 2006). Some characteristics of hopanoids cannot be determined from their mass spectra, i.e., isomerization of $22(\mathrm{R})$ and $22(\mathrm{~S})$. In this regard, retention time has to be considered to identify the compounds, suggesting S always elute earlier than R (Peters et al., 2000; Peters, Walters and Moldowan, 2005b; two possible configuration of an asymmetric carbon atom are called $\mathrm{R}$ and $\mathrm{S}, \mathrm{R}$ indicate the asymmetric carbon points clockwise on the wheel, while S refers to counterclockwise. The biologically produced hopane precursors carry a $22 \mathrm{R}$ configuration, whereas $22 \mathrm{~S}$ do not exist in organisms). In the petroleum industry, these isomerizations occurring in hopanoid skeleton have been widely used as index to determine the thermal maturation for crude oils and source rocks. For example, $\mathrm{C}_{32}$ hopane $22 \mathrm{~S} /(22 \mathrm{~S}+22 \mathrm{R})$, which can be also calculated for other $\mathrm{C}_{31}-\mathrm{C}_{35}$ hopanoidal compounds. This ratio increases with the maturity until it reaches a constant ratio of 0.6 (Peters, Walters and Moldowan, 2005b). 
<smiles>CC(C)CCCC(C)C1CCC2C3CCC4CCCC[C@]4(C)C3CC[C@]12C</smiles>

(1) Sterane $\left(\mathrm{C}_{27} \mathrm{H}_{48}\right)$<smiles>CC(C)=CCC[C@H](C)C1CC[C@]2(C)C3CCC4C(C)(C)[C@@H](O)CC[C@]45C[C@]35CC[C@]12C</smiles>

(3) Cycloartenol $\left(\mathrm{C}_{30} \mathrm{H}_{50} \mathrm{O}\right)$<smiles>CCCC(CCC(C)C1CCC2C3CCC4CCCC[C@]4(C)C3CC[C@]12C)C(C)C</smiles>

(5) 24-n-propylcholestane $\left(\mathrm{C}_{30} \mathrm{H}_{54}\right)$<smiles>C/C(=C\C(C)C1CCC2C3CCC4[C@@H](C)[C@H](O)CCC4(C)C3CCC12C)C(C)C(C)C</smiles>

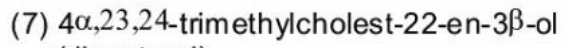
(dinosterol)<smiles>CC(C)=CCC[C@H](C)C1CC[C@]2(C)C3=C(CC[C@]12C)[C@@]1(C)CC[C@H](O)C(C)(C)C1CC3</smiles>

(2) Lanosterol $\left(\mathrm{C}_{30} \mathrm{H}_{50} \mathrm{O}\right)$<smiles>CC(C)CCCC(C)C1CC[C@]2(C)C1CCC1C3CCCC[C@]3(C)CCC12</smiles>

(4) Diasterane $\left(\mathrm{C}_{27} \mathrm{H}_{48}\right)$<smiles>CC(C)C(CCC(C)C1CCC2C3CCC4CCCC[C@]4(C)C3CC[C@]12C)C(C)C</smiles>

(6) 24-isopropylcholestane $\left(\mathrm{C}_{30} \mathrm{H}_{54}\right)$<smiles>CC(C)C(C)C1(C)CC1C(C)C1CCC2C3CC=C4[C@@H](C)[C@@H](O)CCC4(C)C3CCC12C</smiles>

(8) 22,23-methylene-4 $\alpha, 23,24$-trimethylcholest-5-en-3 $\beta$-ol

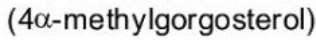

Figure 1.7 Examples of steroids showing the carbon skeletons: (1) Sterane $\left(\mathrm{C}_{27} \mathrm{H}_{48}\right)$; (2) Lanosterol $\left(\mathrm{C}_{30} \mathrm{H}_{50} \mathrm{O}\right)$; (3) Cycloartenol $\left(\mathrm{C}_{30} \mathrm{H}_{50} \mathrm{O}\right)$; (4) Diasterane $\left(\mathrm{C}_{27} \mathrm{H}_{48}\right)$; (5) 24-n-propylcholestane $\left(\mathrm{C}_{30} \mathrm{H}_{54}\right) ;(6)$

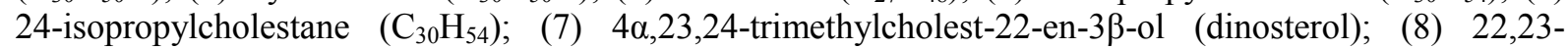
methylene-4 $\alpha, 23,24$-trimethylcholest-5-en-3 $\beta$-ol ( $4 \alpha$-methylgorgosterol) 


\subsubsection{Steroids}

Steroids, consisting of tetracyclic triterpenoids (see Figure 1.7), are formed from cyclization of squalene epoxide (2,3-oxidosqualene) in an $\mathrm{O}_{2}$-dependent pathway that resemble the biosynthetic pathway of hopanoids (Ourisson et al., 1987; Pearson, 2014; Summons et al., 2006). They are vital components of cellular membranes of all eukaryotic organisms and function as controlling membrane's permeability and flexibility. In addition to all eukaryotic organisms, it occurs in microalgae and protozoans (Volkman, 2003). For unknown reasons, a very few bacteria can also produce steroids (Bode et al., 2003; Pearson, Budin and Brocks, 2003). Enzymes involving in sterol biosynthesis, such as oxidosqualene cyclase, convert the compound 2,3-oxidosqualene into one of three biosynthetic intermediates: lanosterol (see Figure 1.7) serve as precursors of cholesterol in animals and fungi, while cycloartenol (see Figure 1.7) and parkeol are sterol intermediates in plants and sea cucumbers (Desmond and Gribaldo, 2009; Dupont et al., 2012; Kushiro and Ebizuka, 2010; Meyer et al., 2000).

The term "desmethylsteranes" is used to identify the steranes that do not have an additional alkyl group at ring A. These desmethylsteranes with 27-29 carbon atoms are the most abundant steranes and occur widespread in fossil materials. Despite the fact that $\mathrm{C}_{27}-\mathrm{C}_{29}$ desmethylsteranes are not characteristics for the specific taxon, they still provide information about their possible biological precursors. For instance, cholestane $\left(\mathrm{C}_{27}\right)$ commonly occurs in animals, algae and plants, while ergostane $\left(\mathrm{C}_{28}\right)$ could be derived from yeasts and fungi, and algae (Brocks and Summons, 2004; Volkman, 2003). For $\mathrm{C}_{29}$ homologues, stigmastane, is typically found in higher plants (Huang and Meinschein, 1979; Volkman, 1986). Diasteranes (see Figure 1.7), steroids with structures distinctly different from normal steranes, have no direct biological precursors. Instead, diasteranes are formed by a diagenetic rearrangement of sterols which is catalized by clay minerals (Brocks and Summons, 2004; Peters, Walters and Moldowan, 2005a; van Kaam-Peters et al., 1998).

Steroids often possess alkyl substituent at position C-24 in the side chain. This is regarded as indicative of eukaryotes, since no bacteria is known so far to have the capacity to alkylate the steroid side chain (Brocks et al., 2003; Volkman, 2003). Specifically, 24-npropylcholestanes (see Figure 1.7) are indicators for marine conditions (Moldowan, Seifert and Gallegos, 1985), and 24-isopropylcholestane skeleton (see Figure 1.7) is typically derived from sponges (McCaffrey et al., 1994b). Furthermore, steranes with alkyl substituents at C-2 or C-3 were detected in some ancient sediments and petroleums, and their biological precursors have not been observed in extant organisms (Summons and Capon, 1988c). 
Instead, they are possibly formed via microbial transformation during the early stages of diagenesis (Summons and Capon, 1991).

Another series of alkylsteranes is methyl group at C-4, and sterols with this corresponding carbon structure are ubiquitous in dinoflagellates, although multiple other potential sources are existing (i.e., Pavlovales order of haptophyte algae, Volkman, Kearney and Jeffrey, 1990; methanotrophic bacteria of the family Methylococcaceae, Schouten et al., 2000a; diatoms, Rampen et al., 2010 and Volkman et al., 1993; higher plants, Yano et al., 1992; and various bacteria, Volkman, 2003 and 2005). As a consequence, relative low concentrations of 4methylsterols are not specific for the particular organisms, but significant amounts can be used as diagnostic biomarkers for dinoflagellates. For instance, one distinctive group of 4-

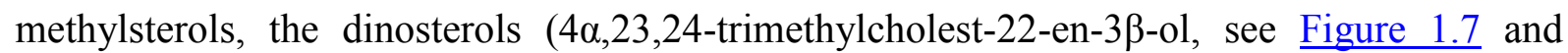
chapter 2), are considered to be an origin of dinoflagellates. In addition, $4 \alpha$-methylgorgosterol

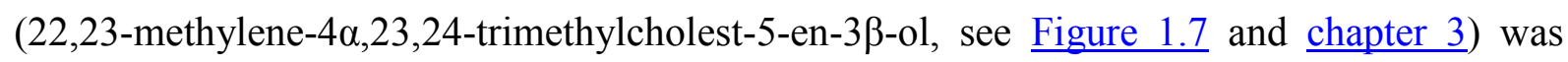
described to occur in some dinoflagellate species, and particularly indicative of the genera Peridinium, Alexandrium and Pyrodinium (Atwood, Volkman and Sachs, 2014; Houle, Lopez and Leblond, 2018), and refs therein.

Steroids are readily identified based on their mass spectra and often investigated as trimethylsilyl (TMS-) derivatives. In the analysis of these derivatives, the ion fragmentation of $\left[\mathrm{m} / \mathrm{z} 129+\left(\mathrm{M}^{+}-90\right)+\mathrm{M}^{+}\right]$for the $\Delta^{5}$-unsaturated sterols and $\left[\mathrm{m} / \mathrm{z} 215+\left(\mathrm{M}^{+}-90\right)+\mathrm{M}^{+}\right]$for the saturated sterols were used for identification. In addition to the above specific fragmentations, retention time are also applied to help identify particular series, i.e., $5 \beta(\mathrm{H})$ stanols elute always earlier than $5 \alpha(\mathrm{H})$-stanols ( $\alpha$ indicate the hydrogen atom is located below the plane of the paper while $\beta$ refers to the position above the plane). Like the hopanoids, isomerization of steroid skeleton is very useful to understand the maturity with respect to the stages of oil generation. For instance, low ratios of $\mathrm{C}_{29}$ sterane $20 \mathrm{~S} /(20 \mathrm{~S}+20 \mathrm{R})$ (configurations at the 20 carbon position) indicate low maturation for the oils, and it reach an equilibrium value of c. 0.55 (Peters, Walters and Moldowan, 2005b).

\subsubsection{Stable isotope signatures}

Fixation or assimilation of inorganic carbon to an accumulation of organic biomass is usually accompanied by significant isotopic fractionation of ${ }^{13} \mathrm{C}$ over ${ }^{12} \mathrm{C}$ (expressed as $\delta^{13} \mathrm{C}$ ). Typical $\delta^{13} \mathrm{C}$ values of inorganic carbon substrates in geological settings ranges from -6 to $-8 \%$ for atmospheric $\mathrm{CO}_{2}$; while presenting -2 to +2 for dissolved $\mathrm{HCO}_{3}{ }^{-}$and $\mathrm{CO}_{3}{ }^{2-}$ (\%): relative to 
standard VPDB; Brocks, 2005). These concomitant fractionations are determined by several factors such as metabolic pathways of organisms, carbon source and environmental conditions. In general, it is well known that organic carbon show depletion in ${ }^{13} \mathrm{C}$ relative to inorganic carbon due to the sizeable fractionation associated with the biologically processed synthesis, and thus the isotopically lighter carbon $\left({ }^{12} \mathrm{C}\right.$-enriched, i.e., with lower $\left.\delta^{13} \mathrm{C}\right)$ of organic compounds have been interpreted as a biosignature (Schidlowski, 2001; Hayes, 2001). Previous works reported light $\delta^{13} \mathrm{C}$ values in Archaean rocks from Isua Supracrustal Belt (West Greenland), suggesting the emergence of early life on Earth dating back to 3800 Myr ago (Mojzsis et al., 1996; Schidlowski, 2001). On the other hand, the carbon fractionation can also be caused abiogenically under certain circumstances (i.e., hydrothermal settings), for instance, from abiotic Fischer-Tropsch-type synthesis (Mccollom et al., 2010; van Zuilen, Lepland and Arrhenius, 2002). Consequently, these findings imply that care must be taken when tracing the evidence of ancient life by using carbon isotope signatures from old rock samples that may have yielded non-biological signals.

Furthermore, $\delta^{13} \mathrm{C}$ measurements have been applied at the molecular level termed as "compound-specific isotope analyses". This isotopic analysis of individual organic biomarker molecules provides valuable information with respect to the paleoenvironments and biogeochemistry of ancient ecosystems (Freeman et al., 1990; Hayes et al., 1990; van der Meer et al., 2001; Schouten et al., 1998b; van der Meer, Schouten and Sinninghe Damsté, 1998).

In addition to carbon, other isotopic systems are also used as indicators for early life, such as sulfur (S) isotopes that show ${ }^{34} \mathrm{~S}$-depletion in Archaean fossil samples, which demonstrate microbial biological activity regulating sulphate reduction processes (Canfield, Farquhar and Zerkle, 2010; Philippot et al., 2007; Shen et al., 2009; Shen and Buick, 2004; Shen, Buick and Canfield, 2001), and the fractionation of iron (Fe) isotopes inferring microbial activity (Beard et al., 1999; Czaja et al., 2013; Icopini et al., 2004), and the applicability of nitrogen (N) isotopes was also investigated as indicative of biogenic processes (Beaumont and Robert, 1999; Papineau et al., 2005; Pinti, Hashizume and Matsuda, 2001). Moreover, several works revealed biological isotope fractionations for the transition metals, for instance preferential assimilation of light molybdenum (Mo) by cyanobacteria (Zerkle et al., 2011), incorporation of light copper $(\mathrm{Cu})$ into cellular protein $(\mathrm{Zhu}$ et al., 2002), fractionation of chromium $(\mathrm{Cr})$ occurred during bacteria reduction pathways (Sikora, Johnson and Bullen, 2008) as well as biogenic uptake of nickel (Ni) and Zinc (Zn), Vance et al., 2017). 


\subsection{Study Site: the atoll of Kiritimati, Central Pacific}

The atoll of Kiritimati (formerly Christmas Island), which was discovered by Captain James Cook in 1777 (Woodroffe and McLean, 1998), is located c. $200 \mathrm{~km}$ north of the Equator at $1^{\circ} 55^{\prime} \mathrm{N}, 157^{\circ} 25^{\prime} \mathrm{W}$ in the Central Pacific (see Figure 1.8). It is the southeasternmost of the Northern Line Islands, c. $41 \mathrm{~km}$ long from NW to SE and $25 \mathrm{~km}$ from north to south coast at the western end. The atoll covers a surface area of (c. $360 \mathrm{~km}^{2}$, Valencia, 1977) and is regarded as the largest coral atoll in the world. The observed distinctive morphologies of the atoll, together with the distributions of lagoon (in the west), the interconnected lakes (in the center) and the dry part (in the east), suggest a drop in sea level after a Mid-Holocene highstand and a possible northwestward tilting on the atoll (Valencia, 1977; Woodroffe and McLean, 1998). The atoll's inland exhibits rather uniform height, with masses of reef rock, not exceeding $4 \mathrm{~m}$ above msl (Wentworth, 1931).

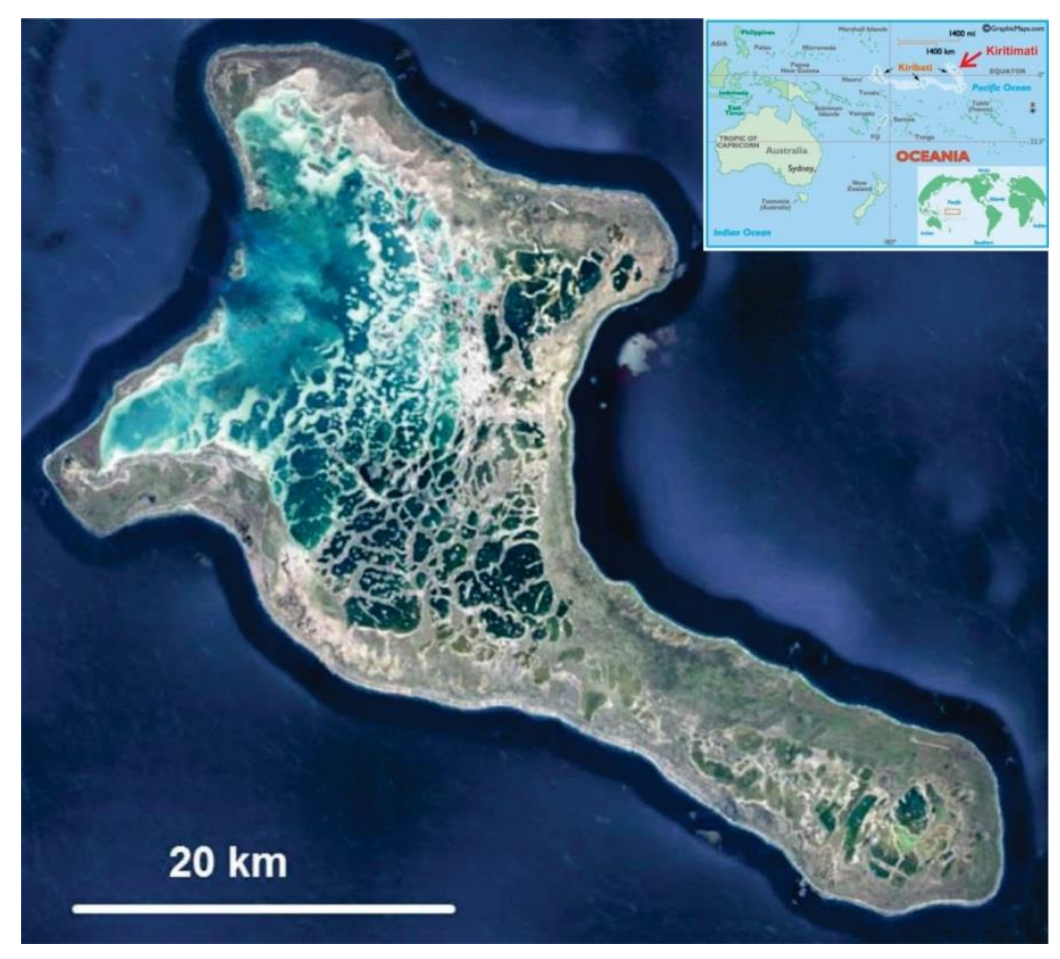

Figure 1.8 Location of the atoll of Kiritimati in the Pacific Ocean and its satellite image showing reticulate distribution of the lakes (from Google Earth and GraphicMaps.com).

The surface of the atoll shows a reticulate pattern formed by numerous lakes (c. 500), with salinities ranging from brackish to hypersaline. Considerable variations between the lakes occur, Trichet et al. (2001), for example, observed salinities of $69 \%$ and $202 \%$ o in two adjacent lakes, and Valencia (1977) reported distinct water levels up to $1 \mathrm{~m}$ between nearby lakes. Most of the lakes are populated by thick and highly developed benthic microbial mats 
showing clear lamination, ongoing mineral precipitation and variations in microbial community (cf. Blumenberg et al., 2013; Blumenberg, Thiel and Reitner, 2015; Bühring et al., 2009; Ionescu et al., 2015; Schneider et al., 2013). During the cold war several nuclear weapon tests occurred in the Kiritimati area, e.g. British military performed hydrogen bombs directly above or near the atoll in 1957 and 1958. Subsequent tests were conducted by the U.S. Army in 1962. This atoll is sparsely inhabited, and it has been only recently recolonized with a population of around 2000 people in 1989, but it significantly increased in recent years, up to 6500 in the census of 2015, and they are currently living in 5 villages on the atoll.

The region of Kiritimati experiences a dry climate, with a variable annual precipitation. For instance, averaging $869 \mathrm{~mm}$ during 1947-1991, while only $177 \mathrm{~mm}$ in 1950. In general, the climate is affected by the El Niño-Southern Oscillation (ENSO) atmospheric phenomenon. This ENSO have significant impact on rainfall and sea level variability of the island, and hence the changes in lake salinities. Specifically, there is recharge of the lakes during El Niño wet events, when heavy rains induce high sea levels and flooding, thus a decrease in lake salinities. However, La Niña dry events triggers reduced precipitation and droughts, causing higher evaporation and increased lake salinities. Most inner part of the atoll is composed of scarce scrub, dominated by Tournefortia argentea, Scaevola taccada, and Suriana maritima, with the ground coverage of Sida fallax, Lepturus repens, Boerhavia tetrandra and Sesuvium portulacastrum (Chock and Hamilton, 1962; Wester, 1985; Woodroffe and McLean, 1998). Furthermore, the primary faunal elements in the lakes include the brine shrimp Artemia, the land crab Gecarcoidea natalis as well as the milkfish Chanos chanos (Saenger et al., 2006; Shen et al., 2018).

\subsection{Integrated analytical methodology}

Several proxies based on biosignatures such as molecular biomarkers, isotope fractionations as well as microfacies are investigated in this work. To a better understanding of these biosignatures and their interactions in modern microbial mats, multiple approaches have been utilized to fulfill the objectives for this thesis. The approaches include histological thin section, Scanning electron microscope (SEM), Gas Chromatography-Mass Spectrometry (GC-MS), Gas Chromatography-Combustion-Isotope Ratio Mass Spectrometry (GC-CIRMS), Pyrolysis-Gas Chromatography-Mass Spectrometry (Py-GC-MS), bulk geochemical analysis and bulk isotope analysis. The more detailed description of these techniques will be given in the following chapters. 


\section{References}

Allwood, A. C., Walter, M. R., Kamber, B. S., Marshall, C. P. and Burch, I. W. (2006). Stromatolite reef from the Early Archaean era of Australia. Nature 441, 714-718.

Anbar, A. D., Duan, Y., Lyons, T. W., Arnold, G. L., Kendal, B., Creaser, R. A., Kaufman, A. J., Gordon, G. W., Scott, C., Garvin, J. and Buick, R. (2007). A whiff of oxygen before the Great Oxidation Event. Science 317, 1903-1906.

Anbar, A. D. and Knoll, A. H. (2002). Proterozoic ocean chemistry and evolution: A bioinorganic bridge? Science 297, 1137-1142.

Arp, G., Helms, G., Karlinska, K., Schumann, G., Reimer, A., Reitner, J. and Trichet, J. (2012). Photosynthesis versus Exopolymer Degradation in the Formation of Microbialites on the Atoll of Kiritimati, Republic of Kiribati, Central Pacific. Geomicrobiology Journal 29, 29-65.

Arp, G., Hofmann, J. and Reitner, J. (1998). Microbial Fabric Formation in Spring Mounds ("Microbialites") of Alkaline Salt Lakes in the Badain Jaran Sand Sea, PR China. PALAIOS 13, 581.

Arp, G., Reimer, A. and Reitner, J. (1999). Calcification in cyanobacterial biofilms of alkaline salt lakes. European Journal of Phycology 34, 393-403.

Arp, G., Reimer, A. and Reitner, J. (2001). Phtosynthesis-induced biofilm calcification and calcium concentrations in Phanerozoic oceans. Science 292, 1701-1704.

Arp, G., Reimer, A. and Reitner, J. (2003). Microbialite Formation in Seawater of Increased Alkalinity, Satonda Crater Lake, Indonesia. Journal of Sedimentary Research 73, 105-127.

Atwood, A. R., Volkman, J. K. and Sachs, J. P. (2014). Characterization of unusual sterols and long chain diols, triols, keto-ols and n-alkenols in El Junco Lake, Galápagos. Organic Geochemistry 66, 80-89.

Bathurst, R. G. C. (1970). Problems of lithification in carbonate muds. Proceedings of the Geologists' Associatin 81, 429-440.

Beard, B. L., Johnson, C. M., Cox, L., Sun, H., Nealson, K. H. and Aguilar, C. (1999). Iron isotope biosignatures. Science 285, 1889-1892.

Beaumont, V. and Robert, F. (1999). Nitrogen isotope ratios of kerogens in Precambrian cherts: a record of the evolution of atmosphere chemistry? Precambrian Research 96, 6382 .

Blumenberg, M., Arp, G., Reitner, J., Schneider, D., Daniel, R. and Thiel, V. (2013). Bacteriohopanepolyols in a stratified cyanobacterial mat from Kiritimati (Christmas Island, Kiribati). Organic Geochemistry 55, 55-62.

Blumenberg, M., Thiel, V. and Reitner, J. (2015). Organic matter preservation in the carbonate matrix of a recent microbial mat - Is there a 'mat seal effect'? Organic Geochemistry 87, 25-34. 
Blumenberg, M., Thiel, V., Riegel, W., Kah, L. C. and Reitner, J. (2012). Biomarkers of black shales formed by microbial mats, Late Mesoproterozoic (1.1Ga) Taoudeni Basin, Mauritania. Precambrian Research 196-197, 113-127.

Bode, H. B., Zeggel, B., Silakowski, B., Wenzel, S. C., Reichenbach, H. and Mueller, R. (2003). Steroid biosynthesis in prokaryotes: identification of myxobacterial steroids and cloning of the first bacterial 2,3(S)oxidosqualene cyclase from the myxobacterium Stigmatella aurantiaca. Molecular microbiology 47, 471-481.

Bolliger, S. A., Ross, S., Thali, M. J., Hostettler, B. and Menkveld-Gfeller, U. (2012). Scenes from the past. Radiographics : a review publication of the Radiological Society of North America, Inc 32, 1553-1559.

Bottjer, D. J., Hagadorn, J. W. and Dornbos, S. Q. (2000). The Cambrian Substrate Revolution. Geological Society of America (GSA Today) 10, 2-8.

Braissant. O., Cailleau. G., Dupraz. C. and Verrecchia. E. P. (2003). Bacterially induced mineralization of calcium carbonate in terrestrial environments. Journal of Sedimentary Research 73, 485-490.

Braissant, O., Decho, A. W., Dupraz, C., Glunk, C., Przekop, K. M. and Visscher, P. T. (2007). Exopolymeric substances of sulfate-reducing bacteria: Interactions with calcium at alkaline $\mathrm{pH}$ and implication for formation of carbonate minerals. Geobiology 5, 401-411.

Brassell, S. C., Comet, P. A., Eglinton, G., McEvoy, J., Maxwell, J. R., Quirke, J. M.E. and Volkman, J. K. (1980). Preliminary lipid analysis of cores 14, 18 and 28 from Deep Sea Drilling Project Hole 416A. Deep Sea Drill Project 50, 647-664.

Brassell, S. C., Wardroper, A. M.K., Thomson, I. D., Maxwell, J. R. and Eglinton, G. (1981). Specific acyclic isoprenoids as biological markers of methanogenic bacteria in marine sediments. Nature 290, 693-696.

Brocks, J. J. (2005). Building the Biomarker Tree of Life. Reviews in Mineralogy and Geochemistry 59, 233-258.

Brocks, J. J., Buick, R., Summons, R. E. and Logan, G. A. (2003). A reconstruction of Archean biological diversity based on molecular fossils from the 2.78 to 2.45 billion-yearold Mount Bruce Supergroup, Hamersley Basin, Western Australia. Geochimica et Cosmochimica Acta 67, 4321-4335.

Brocks, J. J., Jarrett, A. J. M., Sirantoine, E., Hallmann, C., Hoshino, Y. and Liyanage, T. (2017). The rise of algae in Cryogenian oceans and the emergence of animals. Nature 548, $578-581$.

Brocks, J. J., Jarrett, A. J. M., Sirantoin,e E., Kenig, F., Moczydłowska, M., Porter, S. and Hope, J. (2016). Early sponges and toxic protists: possible sources of cryostane, an age diagnostic biomarker antedating Sturtian Snowball Earth. Geobiology 14, 129-149.

Brocks, J. J., Logan, G. A., Buick, R. and Summons, R. E. (1999). Archean Molecular Fossils and the Early Rise of Eukaryotes. Science 285, 1033-1036. 
Brocks, J. J., Love, G. D., Summons, R. E., Knoll, A. H., Logan, G. A. and Bowden, S. A. (2005). Biomarker evidence for green and purple sulphur bacteria in a stratified Palaeoproterozoic sea. Nature 437, 866-870.

Brocks, J. J. and Summons, R. E. (2004). Sedimentary Hydrocarbons, Biomarkers for Early Life. Treatise on Geochemistry 8, 63-115.

Brooks. J. D., Gould. K. and Smith. J. W. (1969). Isoprenoid Hydrocarbons in Coal and Petroleum. Nature 222, 257-259.

Bühring, S. I., Smittenberg, R. H., Sachse, D., Lipp, J. S., Golubic, S., Sachs, J. P., Hinrichs, K. U. and Summons, R. E. (2009). A hypersaline microbial mat from the Pacific Atoll Kiritimati: insights into composition and carbon fixation using biomarker analyses and a ${ }^{13} \mathrm{C}$-labeling approach. Geobiology 7, 308-323.

Burne, R. V. and Moore, L. S. (1987). Microbialites: organosedimentary deposits of benthic microbial communities. PALAIOS 2, 241-254.

Bykova, N., Gill, B. C., Grazhdankin, D., Rogov, V. and Xiao, S. (2017). A geochemical study of the Ediacaran discoidal fossil Aspidella preserved in limestones: Implications for its taphonomy and paleoecology. Geobiology 15, 572-587.

Canfield, D. E., Farquhar, J. and Zerkle, A. L. (2010). High isotope fractionations during sulfate reduction in a low-sulfate euxinic ocean analog. Geology 38, 415-418.

Canfield, D. E., Poulton, S. W. and Narbonne, G. M. (2007). Late-Neoproterozoic deep-ocean oxygenation and the rise of animal life. Science 315, 92-95.

Chafetz, H. S. (1986). Marine Peloids: A Product of Bacterially Induced Precipitation of Calcite. Journal of Sedimentary Petrology 56, 812-817.

Chappe, B., Albrecht, P. and Michaelis, W. (1982). Polar lipids of Archaebacteria in sediments and petroleums. Science 217, 65-66.

Chen, Z., Zhou, C., Xiao, S., Wang, W., Guan, C., Hua, H. and Yuan, X. (2014). New Ediacara fossils preserved in marine limestone and their ecological implications. Scientific reports $4,4180$.

Chock, A. K. and Hamilton, D. C. (1962). Plants of Christmas Island. Atoll Research Bulletin $90,1-7$.

Close, H. G., Bovee, R. and Pearson, A. (2011). Inverse carbon isotope patterns of lipids and kerogen record heterogeneous primary biomass. Geobiology 9, 250-265.

Coates, R. C., Podell, S., Korobeynikov, A., Lapidus, A., Pevzner, P., Sherman, D. H., Allen, E. E., Gerwick, L. and Gerwick, W. H. (2014). Characterization of cyanobacterial hydrocarbon composition and distribution of biosynthetic pathways. PLOS ONE 9, e85140.

Coniglio, M. and James, N. P. (1985). Calcified Algae as Sediment Contributors to Early Paleozoic Limestones. Journal of Sedimentary Research 55, 746-754.

Cranwell, P. A. (1978). Extractable and bound lipid components in a freshwater sediment. Geochimica et Cosmochimica Acta 42, 1523-1532. 
Cranwell, P. A. (1982). Lipids of aquatic sediments and sedimenting particulates. Progress in Lipid Research 21, 271-308.

Cranwell, P. A., Eglinton, G. and Robinson, N. (1987). Lipids of aquatic organisms as potential contributors to lacustrine sediments-- II *. Organic Geochemistry 11, 513-527.

Crépeau, V., Cambon Bonavita, M.-A., Lesongeur, F., Randrianalivelo, H., Sarradin, P.-M., Sarrazin, J. and Godfroy, A. (2011). Diversity and function in microbial mats from the Lucky Strike hydrothermal vent field. FEMS Microbiology Ecology 76, 524-540.

Czaja, A. D., Johnson, C. M., Beard, B. L., Roden, E. E., Li, W. and Moorbath, S. (2013). Biological Fe oxidation controlled deposition of banded iron formation in the ca. 3770Ma Isua Supracrustal Belt (West Greenland). Earth and Planetary Science Letters 363, 192203.

Dahl, T. W., Hammarlund, E. U., Anbar, A. D., Bond, D. P. G., Gill, B. C., Gordon, G. W., Knoll, A. H., Nielsen, A. T., Schovsbo, N. H. and Canfield, D. E. (2010). Devonian rise in atmospheric oxygen correlated to the radiations of terrestrial plants and large predatory fish. Proc Natl Acad Sci USA 107, 17911-17915.

Decho, A. (1990). Microbial expolymer secretions in ocean environments: their role(s) in food webs and marine processes. Oceanography and Marine Biology Annual Review 28, 73-153.

Decho A. W. (2000). Exopolymer microdomains as a structuring agent for heterogeneity within microbial biofilms. Microbial Sediments Spring-Verlag, Berlin, 9-15.

Des Marais, D. J. (2003). Biogeochemistry of hypersaline microbial mats illustrates the dynamics of modern microbial ecosystems and the early evolution of the biosphere. The Biological bulletin 204, 160-167.

Desmond, E. and Gribaldo, S. (2009). Phylogenomics of sterol synthesis. Genome biology and evolution 1, 364-381.

Didyk, B. M., Simoneit, B. R.T., Brassell, S. C. and Eglinton, G. (1978). Organic geochemical indicators of palaeoenvironmental conditions of sedimentation. Nature 272, 216-222.

Dow, W. G. (1977). Kerogen studies and geological interpretations. Journal of Geochemical exploration 7, 79-99.

Dowling, N. J.E., Widdel, F. and White, D. (1986). Phospholipid ester-linked fatty acid biomarkers of acetate-oxidizing sulphate-reducers and other sulphide-forming bacteria. Journal of General Microbiology 132, 1815-1825.

Dupont, S., Lemetais, G., Ferreira, T., Cayot, P., Gervais, P. and Beney, L. (2012). Ergosterol biosynthesis. Evolution; international journal of organic evolution 66, 2961-2968.

Dupraz, C., Reid, R. P., Braissant, O., Decho, A. W., Norman, R. S. and Visscher, P. T. (2009). Processes of carbonate precipitation in modern microbial mats. Earth-Science Reviews 96, 141-162. 
Dupraz, C., Reid, R. P. and Visscher, P. T. (2011). Microbialites, Modern. Encyclopedia, 617-635.

Dupraz, C. and Strasser, A. (1999). Microbialites and micro-encrusters in shallow coral bioherms (Middle to Late Oxfordian, Swiss Jura mountains). Facies 40, 101-129.

Dupraz, C. and Strasser, A. (2002). Nutritional Modes in Coral-Microbialite Reefs (Jurassic, Oxfordian, Switzerland) Evolution of Trophic Structure as a Response to Environmental Change. PALAIOS 17, 449-471.

Dupraz, C. and Visscher, P. T. (2005). Microbial lithification in marine stromatolites and hypersaline mats. Trends in microbiology 13, 429-438.

Dupraz, C., Visscher, P. T., Baumgartner, L. K. and Reid, R. P. (2004). Microbe-mineral interactions: early carbonate precipitation in a hypersaline lake (Eleuthera Island, Bahamas). Sedimentology 51, 745-765.

Eglinton, G. and Hamilton, R. J. (1967). Leaf Epicuticular Waxes. Science 156, 1322-1335.

Eglinton, G., Hunneman, D. H. and Douraghi-Zadeh, K. (1968). Gas chromatographic-mass spectrometric studies of long chain hydroxy acids-II: The hydroxy acids and fatty acids of a 5000-year-old lacustrine sediment. Tetrahedron 24, 5929-5941.

Fehler, S. W. G. and Light, R. J. (2002). Biosynthesis of hydrocarbons in Anabaena variabilis. Incorporation of [methyl- $14 \mathrm{C}$ ] and [methyl- $2 \mathrm{H} 2$ ] Methionine into 7- and 8-methylheptadecanes. Biochemistry 9, 418-422.

Ficken, K. J., Li, B., Swain, D. L. and Eglinton, G. (2000). An n-alkane proxy for the sedimentary input of submerged/floating freshwater aquatic macrophytes. Organic Geochemistry, 745-749.

Flügel, E. and Munnecke, A. (2010). Microfacies of carbonate rocks. Springer, Heidelberg, New York.

Fowler, M. G. and Douglas, A. G. (1987). Saturated hydrocarbon biomarkers in oils of Late Precambrian age from Eastern Siberia. Organic Geochemistry 11, 201-213.

Fowler, S. W. and Knauer, G. A. (1986). Role of large particles in the transport of elements and organic compounds through the oceanic water column. Progress in Oceanography 16, 147-194.

Freeman, K. H., Hayes, J. M., Trendel, J.-M. and Albrecht, P. (1990). Evidence from carbon isotope measurements for diverse origins of sedimentary hydrocarbons. Nature 343, 254256.

Goossens, H., de Leeuw, J. W., Schenck, P. A. and Brassell, S. C. (1984). Tocopherols as likely precursors of pristane in ancient sediments and crude oils. Nature 312, 440-442.

Grantham, P. J. (1986). The occurrence of unusual C27 and C29 sterane predominances in two types of Oman crude oil. Organic Geochemistry 9, 1-10.

Gray, J. and Boucot, A. J. (1978). The advent of land plant life. Geology 6, 489-492. 
Grice, K., Schouten, S., Nissenbaum, A., Charrach, J. and Sinninghe Damsté, J. S. (1998). Isotopically heavy carbon in the $\mathrm{C} 21$ to $\mathrm{C} 25$ regular isoprenoids in halite-rich deposits from the Sdom Formation, Dead Sea Basin, Israel. Organic Geochemistry 28, 349-359.

Grotzinger, J. P. and Knoll, A. H. (1999). Stromatolites in Precambrian carbonates: evolutionary mileposts or environmental dipsticks? Annual review of earth and planetary sciences $27,313-358$.

Guerrero, M. C. and de Wit, R. (1992). Microbial mats in the inland saline lakes of Spain. Limnetica 8, 197-204.

Han, J. and Calvin, M. (1969). Hydrocarbon distribution of algae and bacteria, and microbiological activity in sediments. Chemistry 64, 436-443.

Hayes, J. M. (2001). Fractionation of the isotopes of carbon adn hydrogen in biosynthetic process. Mineralogy and Geochemistry, 1-31.

Hayes, J. M., Freeman, K. H., Popp, B. N. and Hoham, C. H. (1990). Compound-specific isotopic analyses: A novel tool for reconstruction of ancient biogeochemical processes. Organic Geochemistry 16, 1115-1128.

Heindel, K., Birgel, D., Brunner, B., Thiel, V., Westphal, H., Gischler, E., Ziegenbalg, S. B., Cabioch, G., Sjövall, P. and Peckmann, J. (2012). Post-glacial microbialite formation in coral reefs of the Pacific, Atlantic, and Indian Oceans. Chemical Geology 304-305, 117 130 .

Heindel, K., Birgel, D., Peckmann, J., Kuhnert, H. and Westphal, H. (2010). Formation of deglacial microbialites in coral reefs off Tahiti (IODP 310) involving sulfate-reducing bacteria. PALAIOS 25, 618-635.

Hills, B. I.R. and Whitehead, E. V. (1966). An optically active triterpane, Gammacerane in Green River, Colorado, oil shale bitumen. Chemical Communications, 752-754.

Hinrichs, K.-U., Summons, R. E., Orphan, V., Sylva, S. P. and Hayes, J. M. (2000). Molecular and isotopic analysis of anaerobic methan-oxidizing communities in marine sediments. Organic Geochemistry 31, 1685-1701.

Hoefs, M. J. L., Schouten, S., de Leeuw, J. W., King, L. L., Wakeham, S. G. and Sinninghe Damsté, J. S. (1997). Ether Lipids of Planktonic Archaea in the Marine Water Column. Appl. Environ. Microbiol. 63, 3090-3095.

Höld, I. M., Schouten, S., Jellema, J. and Sinninghe Damsté J. S. (1999). Origin of free and bound mid-chain methyl alkanes in oils, bitumens and kerogens of the marine, Infracambrian Huqf Formation (Oman). Organic Geochemistry 30, 1411-1428.

Holland, H. D. (2006). The oxygenation of the atmosphere and oceans. Philosophical transactions of the Royal Society of London. Series B, Biological sciences 361, 903-915.

Houle, H. M., Lopez, C. B. and Leblond, J. D. (2018). Sterols of the Toxic Marine Dinoflagellate, Pyrodinium bahamense. The Journal of eukaryotic microbiology, 1-5. 
Hren, M. T., Pagani, M., Erwin, D. M. and Brandon, M. (2010). Biomarker reconstructionof the early Eocene paleotopography and paleoclimate of the nothern Sierra Nevada. Geology Society of America 38, 7-10.

Huang, W.-Y. and Meinschein, W. G. (1979). Sterols as ecological indicators. Geochimica et Cosmochimica Acta 43, 739-745.

Icopini, G. A., Anbar, A. D., Ruebush, S. S., Tien, M. and Brantley, S. L. (2004). Iron isotope fractionation during microbial reduction of iron: The importance of adsorption. Geology 32, 205-208.

Ionescu, D., Spitzer, S., Reimer, A., Schneider, D., Daniel, R., Reitner, J., de Beer, D. and Arp, G. (2015). Calcium dynamics in microbialite-forming exopolymer-rich mats on the atoll of Kiritimati, Republic of Kiribati, Central Pacific. Geobiology 13, 170-180.

Ishiwatari, R. and Hanya, T. (1975). Organic geochemistry of a 200-meter core sample from Lake Biwa. II Vertical distribution of Mono- and Di-carboxylic acids and polynuclear aromatic hydrocarbons. Proceedings of the Japan Academy 51, 436-441.

Jahnke, L. L. (1986). The effects of low oxygen on the synthesis of unsaturated fatty acids and sterols: Implications for the evolution of eukaryotes. Origins of Life and Evolution of the Biosphere 16, 317-318.

Johns, R. B. and Onder, O. M. (1975). Biological diagenesis: dicarboxylic acids in recent sediments. Geochimica et Cosmochimica Acta 39, 129-136.

Johnston, D. T., Poulton, S. W., Tosca, N. J., O'Brien, T., Halverson, G. P., Schrag, D. P. and Macdonald, F. A. (2013). Searching for an oxygenation event in the fossiliferous Ediacaran of northwestern Canada. Chemical Geology 362, 273-286.

Peters, K. E., Snedden, J. W., Sulaeman, A., Sarg, J. F. and Enrico, R. J. (2000). A New Geochemical-Sequence Stratigraphic Model for the Mahakam Delta and Makassar Slope, Kalimantan, Indonesia1. Bulletin 84, 12-44.

Kaneda, T. (1991). Iso- and Anteiso-Fatty Acids in Bacteria: Biosynthesis, Function, and Taxonomic Significance. Microbiological Review 55, 288-302.

Kannenberg, E. L. and Poralla, K. (1999). Hopanoid biosynthesis and function in bacteria. Naturwissenschaften 86, 168-176.

Kates, M. (1997). Diether and Tetraether Phospholipids and Glycolipids as Molecular Markers for Archaebacteria (Archaea). In Molecular Markers in Environmental Geochemistry (ed. R. P. Eganhouse). American Chemical Society. Washington, DC, pp. $35-48$.

Kazmierczak, J., Coleman, M. L., Gruszczynski, M. and Kempse, S. (1996). Cyanobacterial key to the genesis of micritic and peloidal limestones in ancient seas. Acta Palaeontologica Polonica 41, 319-338.

Kenig, F., Sinninghe Damsté, J. S., Kock-van Dalen, A. C., Rijpstra, W. I. C., Huc, A. Y. and de Leeuw, J. W. (1995). Occurrence and origin of mono-, di-, and trimethylalkanes in modern and Holocene cyanobacterial mats from Abu Dhabi, United Arab Emirates. Geochimica et Cosmochimica Acta 59, 2999-3015. 
Kimble, B. J., Maxwell, J. R., Philp, R. P., Albrecht, P., Ensminger A., Arpino, P. and Ourisson, G. (1974). Tri- and tetraterpenoid hydrocarbons in the Messel oil shale. Geochimica et Cosmochimica Acta 38, 1165-1181.

Kissin, Y. V. (1987). Catagenesis and composition of petroleum: Origin of n-alkanes and isoalkanes in petroleum crudes. Geochimica et Cosmochimica Acta 51, 2445-2457.

Knoll, A. H. (2011). The Multiple Origins of Complex Multicellularity. Annu. Rev. Earth Planet. Sci. 39, 217-239.

Knoll, A. H. (2014). Paleobiological perspectives on early eukaryotic evolution. Cold Spring Harbor perspectives in biology 6, 1-14.

Knoll, A. H., Summons, R. E., Waldbauer, J. R. and Zumberge, J. E. (2007). The Geological Succession of Primary Producers in the Oceans. In Evolution of Primary Producers in the Sea. Elsevier, pp. 133-163.

Kohnen, M. E., Schouten, S., Sinninghe Damsté, J. S., de Leeuw, J. W., Merritt, D. A. and Hayes, J. M. (1992). Recognition of paleobiochemicals by a combine molecular sulfur and isotope geochemical approach. Science 256, 358-362.

Kolattukudy, P. E. (1980). Biopolyester membranes of plants: cutin and suberin. Science 208, 990-1000.

Kushiro, T. and Ebizuka, Y. (2010). Triterpenes. In Comprehensive Natural Products II. Elsevier, pp. 673-708.

Liu, Z., Pagani, M., Zinniker, D., DeConto, R., Huber, M., Brinkhuis, H., Shah, S. R., Leckie, R. M. and Pearson, A. (2009). Global cooling during the Eocene-Oligocene climate trasition. Science 323, 1187-1190.

Logan, G. A., Hayes, J. M., Hieshima, G. B. and Summons, R. E. (1995). Terminal Proterozoic reorganization of biogeochemical cycles. Nature 376, 53-56.

Love, G. D., Grosjean, E., Stalvies, C., Fike, D. A., Grotzinger, J. P., Bradley, A. S., Kelly, A. E., Bhatia, M., Meredith, W., Snape, C. E., Bowring, S. A., Condon, D. J. and Summons, R. E. (2009). Fossil steroids record the appearance of Demospongiae during the Cryogenian period. Nature 457, 718-721.

Mackenzie, R., Pedrós-Alió, C. and Díez, B. (2013). Bacterial composition of microbial mats in hot springs in Northern Patagonia. Extremophiles : life under extreme conditions 17, $123-136$.

McCaffrey, M. A., Farrington, J. W. and Repeta, D. J. (1991). The organic geochemistry of Peru margin surface sediments: Geochimica et Cosmochimica Acta 55, 483-498.

McCaffrey, M. A., Moldowan, J. M., Lipton, P. A., Summons, R. E., Peters, K. E., Jeganathan, A. and Watt, D. S. (1994a). Paleoenvironmental implications of novel $\mathrm{C}_{30}$ steranes in Precambrian to Cenozoic age petroleum and bitumen. Geochimica et Cosmochimica Acta 58, 529-532.

McCaffrey, M. A., Moldowan, J. M., Lipton, P. A., Summons, R. E., Peters, K. E., Jeganathan, A. and Watt, D. S. (1994b). Paleoenvironmental implications of novel $C_{30}$ 
steranes in Precambrian to Cenozoic Age petroleum and bitumen. Geochimica et Cosmochimica Acta 58, 529-532.

Mccollom, T. M., Lollar, B. S., Lacrampe-Couloume, G. and Seewald, J. S. (2010). The influence of carbon source on abiotic organic synthesis and carbon isotope fractionation under hydrothermal conditions. Geochimica et Cosmochimica Acta 74, 2717-2740.

Meyer, M. M., Segura, M. J., Wilson, W. K. and Matsuda, S. P. (2000). Oxidosqualene Cyclase Residues that Promote Formation of Cycloartenol, Lanosterol, and Parkeol. Angewandte Chemie 39, 4090-4092.

Meyers, P. A. (2003). Applications of organic geochemistry to paleolimnological reconstructions: a summary of examples from the Laurentian Great Lakes. Organic Geochemistry 34, 261-289.

Mojzsis, S. J., Arrhenius, G., McKeegan, K. D., Harrison, T. M., Nutman, A. P. and Friend, C. R.L. (1996). Evidence for life on Earth before 3,800 million years ago. Nature 384, 55-59.

Moldowan, J. M., Dahl, J., Huizinga, B. J., Fago, J. F., Hickey, L. J., Peakman, T. M. and Taylor, D. W. (1994). The molecular fossil record of Oleanane and its relation to Angiosperms. Science 265, 768-771.

Moldowan, J. M., Seifert, W. K. and Gallegos, E. J. (1985). Relationship Between Petroleum Composition and Depositional Environment of Petroleum Source Rocks. Bulletin 69, $1255-1268$.

Moldowan, J. M. and Talyzina, N. M. (1998). Biogeochemical evidence for dinoflagellate ancestors in the early Cambrian. Science 281.

Monty, C.L.V. (1976). Chapter 5.1. Developments in Sedimentology 20, 193-249.

Morris, J. L., Puttick, M. N., Clark, J. W., Edwards, D., Kenrick, P., Pressel, S., Wellman, C. H., Yang, Z., Schneider, H. and Donoghue, P. C. J. (2018). The timescale of early land plant evolution. Proc Natl Acad Sci USA 115, E2274-E2283.

Nichols, J. E., Booth, R. K., Jackson, S. T., Pendall, E. G. and Huang, Y. (2006). Paleohydrologic reconstruction based on n-alkane distributions in ombrotrophic peat. Organic Geochemistry 37, 1505-1513.

Nielsen, P. H., Jahn, A. and Palmgren, R. (1997). Conceptual model for production and composition of exopolymers in biofilms. Water Science and Technology 36, 11-19.

Noffke, N., Christian, D., Wacey, D. and Hazen, R. M. (2013). Microbially induced sedimentary structures recording an ancient ecosystem in the ca. 3.48 billion-year-old Dresser Formation, Pilbara, Western Australia. Astrobiology 13, 1103-1124.

Noffke, N., Eriksson, K. A., Hazen, R. M. and Simpson, E. L. (2006). A new window into Early Archean life: Microbial mats in Earth's oldest siliciclastic tidal deposits (3.2 Ga Moodies Group, South Africa). Geology Society of America 34, 253-256.

Ourisson, G. and Albrecht, P. (1992). Hopanoids. 1. Geohopanoids. Acc. Chem. Res. 25, 398402. 
Ourisson, G., Albrecht, P. and Rohmer, M. (1979). The Hopanoids. Pure and Applied Chemistry 51, 709-730.

Ourisson, G., Rohmer, M. and Poralla, K. (1987). Prokaryotic hopanoids and other oolyterpenoid sterol surrogates. Annu. Rev. Microbiology 41, 301-333.

Pancost, R., Sinninghe Damsté, J. S., de Lint, S., van der Maarel, M. J.E.C., Gottschal, J. C. and The medinaut shipboard scientific party (2000a). Biomarker Evidence for widespread anaerobic methane oxidation in Mediterranean sediments by a consortium of methanogenic archaea and bacteria. Appl. Environ. Microbiol. 66, 1126-1132.

Pancost, R., van Geel, B., Baas, M. and Sinninghe Damsté, J. S. (2000b). $\delta^{13}$ C values and radiocarbon dates of microbial biomarkers as tracers for carbon recycling in peat deposits. Geology 28, 663-666.

Papineau, D., Mojzsis, S. J., Karhu, J. A. and Marty, B. (2005). Nitrogen isotopic composition of ammoniated phyllosilicates. Chemical Geology 216, 37-58.

Pawlowska, M. M., Butterfield, N. J. and Brocks, J. J. (2013). Lipid taphonomy in the Proterozoic and the effect of microbial mats on biomarker preservation. Geology 41, 103106.

Pearson, A. (2014). Lipidomics for Geochemistry. In Treatise on Geochemistry. Elsevier, pp. 291-336.

Pearson, A., Budin, M. and Brocks, J. J. (2003). Phylogenetic and biochemical evidence for sterol synthesis in the bacterium Gemmata obscuriglobus. Proc Natl Acad Sci USA 100, $15352-15357$.

Perri, E., Tucker, M. E. and Spadafora, A. (2012). Carbonate organo-mineral micro- and ultrastructures in sub-fossil stromatolites. Geobiology 10, 105-117.

Peters, K. E., Walters, C. C. and Moldowan, J. M. (2005a). The Biomarker Guide. Cambridge University Press, 1-474.

Peters, K. E., Walters, C. C. and Moldowan, J. M. (2005b). The Biomarker Guide. Cambridge University Press, 475-1155.

Philippot, P., van Zuilen, M., Lepot, K., Thomazo, C., Farquhar, J. and van Kranendonk, M. J. (2007). Early Archaean Microorganisms Preferred Elemental Sulfur, Not Sulfate. Science 317, 1534-1537.

Pinti, D. L., Hashizume, K. and Matsuda, J.-I. (2001). Nitrogen and argon signatures in 3.8 to 2.8 Ga metasediments: Clues on the chemical state of the Archean ocean and the deep biosphere. Geochimica et Cosmochimica Acta 65, 2301-2315.

Planavsky, N. J., Asael, D., Hofmann, A., Reinhard, C. T., Lalonde, S. V., Knudsen, A., Wang, X., Ossa, F., Pecoits, E., Smith, A. J. B., Beukes, N. J., Bekker, A., Johnson, T. M., Konhauser, K. O., Lyons, T. W. and Rouxel, O. J. (2014a). Evidence for oxygenic photosynthesis half a billion years before the Great Oxidation Event. Nature Geosci 7, 283-286. 
Planavsky, N. J., Reinhard, C. T., Wang, X., Thomson, D., McGoldrick, P., Rainbird, R. H., Johnson, T., Fischer, W. W. and Lyons, T. W. (2014b). Low Mid-Proterozoic atmospheric oxygen levels and the delayed rise of animals. Science 346, 623-638.

Porter, S. M. and Knoll, A. H. (2000). Testate amoebae in the Neoproterozoic Era. Paleobiology 26, 360-385.

Powell, T. G. and McKirdy, D. M. (1973). Relationship between Ratio of Pristane to Phytane, Crude Oil Composition and Geological Environment in Australia. Nature Physical Science 243, 37-39.

Prieto-Barajas, C. M., Valencia-Cantero, E. and Santoyo, G. (2018). Microbial mat ecosystems. Electronic Journal of Biotechnology 31, 48-56.

Ramos, V. M. C., Castelo-Branco, R., Leão, P. N., Martins, J., Carvalhal-Gomes, S., Sobrinho da Silva, F., Mendonça Filho, J. G. and Vasconcelos, V. M. (2017). Cyanobacterial Diversity in Microbial Mats from the Hypersaline Lagoon System of Araruama, Brazil. Frontiers in microbiology 8, 1233.

Rampen, S. W., Abbas, B. A., Schouten, S. and Sinninghe Damsté, J. S. (2010). A comprehensive study of sterols in marine diatoms (Bacillariophyta): Implications for their use as tracers for diatom productivity. Limnol. Oceanogr. 55, 91-105.

Reid, R. P. (1987). Nonskeletal Peloidal Precipitates in Upper Triassic Reefs, Yukon Territory (Canada). Journal of Sedimentary Research Vol. 57.

Reitner, J. (1993). Modern cryptic microbialite/metazoan facies from Lizard Island (Great Barrier Reef, Australia)formation and concepts. Facies 29, 3-40.

Reitner, J., Gautret, P., Marin, F. and Neuweiler, F. (1995). Automicrites in a modern marine microbialites. Formation model via organic matrices (Lizard Island, Great Barrier Reef, Australia). Bull. Inst. Océan. Monaco 14, 237-263.

Reitner, J., Peckmann, J., Blumenberg, M., Michaelis, W., Reimer, A. and Thiel, V. (2005). Concretionary methane-seep carbonates and associated microbial communities in Black Sea sediments. Palaeogeography, Palaeoclimatology, Palaeoecology 227, 18-30.

Reitner, J. and Thiel, V. (2011). Encoclopedia of geobiology. Springer, 1-956.

Riding, R. (1991). Calcareous algae and stromatolites. Springer-Verlag, Berlin, New York.

Riding, R. (2000). Microbial carbonates: the geological record of calcified bacterialalgal mats and biofilms. Sedimentology 47, 179-214.

Riding, R. (2002a). Biofilm architecture of Phanerozoic cryptic carbonate marine veneers. Geology 30, 31-34.

Riding, R. (2002b). Structure and composition of organic reefs and carbonate mud mounds: concepts and categories. Earth-Science Reviews 58, 163-231.

Riding, R. (2011). The Nature of Stromatolites: 3,500 Million Years of History and a Century of Research. In Advances in Stromatolite Geobiology (eds. J. Reitner, N.-V. Quéric and G. Arp). Springer Berlin Heidelberg. Berlin, Heidelberg, pp. 29-74. 
Riding, R. and Tomas, S. (2006). Stromatolite reef crusts, Early Cretaceous, Spain. Sedimentology 53, 23-34.

Rohmer, M., Bouvier, P. and Guy, O. (1979). Molecular evolution of biomembranes: Structural equivalents and phylogenetic precursors of sterols. Proc Natl Acad Sci USA 76, 847-851.

Rohmer, M., Bouvier-Nave, P. and Ourisson, G. (1984). Distribution of hopanoid triterpenes in prokaryotes. Journal of General Microbiology 130, 1137-1150.

Rohmer, M., Dastillung, M. and Ourisson, G. (1980). Hopanoids from C30 to C35 in recent muds. Naturwissenschaften 67, 456-458.

Romano, I., Finore, I., Nicolaus, G., Huertas, F. J., Lama, L., Nicolaus, B. and Poli, A. (2008). Halobacillus alkaliphilus sp. nov., a halophilic bacterium isolated from a salt lake in Fuente de Piedra, southern Spain. International journal of systematic and evolutionary microbiology 58, 886-890.

Sachse, D., Radke, J. and Gleixner, G. (2004). Hydrogen isotope ratios of recent lacustrine sedimentary n-alkanes record modern climate variability. Geochimica et Cosmochimica Acta 68, 4877-4889.

Saenger, C., Miller, M., Smittenberg, R. H. and Sachs, J. P. (2006). A physico-chemical survey of inland lakes and saline ponds: Christmas Island (Kiritimati) and Washington (Teraina) Islands, Republic of Kiribati. Saline systems 2, 1-15.

Sáenz, J. P., Grosser, D., Bradley, A. S., Lagny, T. J., Lavrynenko, O., Broda, M. and Simons, K. (2015). Hopanoids as functional analogues of cholesterol in bacterial membranes. Proc Natl Acad Sci USA 112, 11971-11976.

Sahoo, S. K., Planavsky, N. J., Kendall, B., Wang, X., Shi, X., Scott, C., Anbar, A. D., Lyons, T. W. and Jiang, G. (2012). Ocean oxygenation in the wake of the Marinoan glaciation. Nature 489, 546-549.

Scherf, A.-K. and Rullkötter, J. (2009). Biogeochemistry of high salinity microbial mats Part 1. Organic Geochemistry 40, 1018-1028.

Schidlowski, M. (2001). Carbon isotopes as biogeochemical recorders of life over $3.8 \mathrm{Ga}$ of Earth history: evolution of a concept. Precambrian Research 106, 117-134.

Schneider, D., Arp, G., Reimer, A., Reitner, J. and Daniel, R. (2013). Phylogenetic Analysis of a Microbialite-Forming Microbial Mat from a Hypersaline Lake of the Kiritimati Atoll, Central Pacific. PLoS ONE 8, e66662.

Schouten, S., Bowman, J. P., Rijpstra, W. I. C. and Sinninghe Damsté, J. S. (2000a). Sterols in a psychrophilic methanotroph, Methylosphaera hansonii. FEMS Microbiology Letters 186, 193-195.

Schouten, S., Hoefs, M. J., Koopmans, M. P., Bosch, H.-J. and Sinninghe Damsté, J. S. (1998a). Structural characterization, occurrence and fate of archaeal ether-bound acyclic and cyclic biphytanes and corresponding diols in sediments. Organic Geochemistry 29, 1605-1319. 
Schouten, S., Hopmans, E. C., Pancost, R. and Sinninghe Damsté, J. S. (2000b). Widespread occurrence of structurally diverse tetraether membrane lipids: Evidence for the ubiquitous presence of low-temperature relatives of hyperthermophiles. Proc Natl Acad Sci USA 97, $14421-14426$.

Schouten, S., Hopmans, E. C. and Sinninghe Damsté, J. S. (2013). The organic geochemistry of glycerol dialkyl glycerol tetraether lipids. Organic Geochemistry 54, 19-61.

Schouten, S., Klein Breteler, W. C. M., Blokker, P., Schogt, N., Rijpstra, W. I. C., Grice, K., Baas, M. and Sinninghe Damsté, J. S. (1998b). Biosynthetic effects on the stable carbon isotopic compositions of algal lipids: Implications for deciphering the carbon isotopic biomarker record. Geochimica et Cosmochimica Acta 62, 1397-1406.

Schouten, S., Schoell, M., Rijpstra, W. I. C., Sinninghe Damsté, J. S. and de Leeuw, J. W. (1997). A molecular stable carbon isotpe study of organic matter in immature Miocene Monterey sediments, Pismo basin. Geochimica et Cosmochimica Acta 61, 2065-2082.

Schuler, C. G., Havig, J. R. and Hamilton, T. L. (2017). Hot Spring Microbial Community Composition, Morphology, and Carbon Fixation. Front. Earth Sci. 5, e0132783.

Seckbach, J. and Oren, A. (2010). Microbial mats. Springer, Dordrecht, New York.

Seilacher, A. (2007). Trace Fossil Analysis. Springer Berlin Heidelberg, Berlin, Heidelberg.

Seilacher, A. (1999). Biomat-Related Lifestyles in the Precambrian. PALAIOS 14, 86-93.

Seilacher, A. and Pflüger, F. (1994). From biomats to benthic agriculture: A biohistoric revolution. Biostablization of Sediments, 97-105.

Sessions, A. L., Zhang, L., Welander, P. V., Doughty, D., Summons, R. E. and Newman, D. K. (2013). Identification and quantification of polyfunctionalized hopanoids by high temperature gas chromatography-mass spectrometry. Organic Geochemistry 56, 120-130.

Shen, Y. and Buick, R. (2004). The antiquity of microbial sulfate reduction. Earth-Science Reviews 64, 243-272.

Shen, Y., Buick, R. and Canfield, D. E. (2001). Isotopic evidence for microbial sulphate reduction in the early Archaean era. Nature 410, 77-81.

Shen, Y., Farquhar, J., Masterson, A., Kaufman, A. J. and Buick, R. (2009). Evaluating the role of microbial sulfate reduction in the early Archean using quadruple isotope systematics. Earth and Planetary Science Letters 279, 383-391.

Shen, Y., Thiel, V., Duda, J.-P. and Reitner, J. (2018). Tracing the fate of steroids through a hypersaline microbial mat (Kiritimati, Kiribati/Central Pacific). Geobiology 16, 307-318.

Shiea, J., Brassel, S. C. and Ward, D. M. (1991). Comparative analysis of extractable lipids in hot spring microbial mats and their component photosynthetic bacteria. Organic Geochemistry 17, 309-319.

Shiea, J., Brassell, S. C. and Ward, D. M. (1990). Mid-chain branched mono- and dimethyl alkanes in hot spring cyanobacterial mats: A direct biogenic source for branched alkanes in ancient sediments. Organic Geochemistry 15, 223-232. 
Sikora, E. R., Johnson, T. M. and Bullen, T. D. (2008). Microbial mass-dependent fractionation of chromium isotopes. Geochimica et Cosmochimica Acta 72, 3631-3641.

Sinninghe Damsté, J. S., Muyzer, G., Abbas, B., Rampen, S. W., Masse, G., Allard, G., Moldowan, J. M., Barbanti, S. M., Fago, F. J., Denisevich, P., Dahl, J., Trindade, L. A.F. and Schouten, S. (2004). The rise of the Rhizosolenid diatoms. Science 304, 584-587.

Sinninghe Damsté, J. S., Kenig, F., Koopmans, M. P., Köster, J., Schouten, S., Hayes, J. M. and de Leeuw, J. W. (1995). Evidence for gammacerane as an indicator of water column stratification. Geochimica et Cosmochimica Acta 59, 1895-1900.

Sinninghe Damsté, J. S., Kuypers, M. M.M., Schulte S. and Rullkötter J. (2003). The lycopane/C31 n-alkane ratio as a proxy to assess palaeoxicity during sediment deposition. Earth and Planetary Science Letters 209, 215-226.

Sinninghe Damsté, J. S., Rijpstra, W. I. C., Dedysh, S. N., Foesel, B. U. and Villanueva, L. (2017). Pheno- and Genotyping of Hopanoid Production in Acidobacteria. Frontiers in microbiology 8, 968.

Słowakiewicz, M., Whitaker, F., Thomas, L., Tucker, M. E., Zheng, Y., Gedl, P. and Pancost, R. D. (2016). Biogeochemistry of intertidal microbial mats from Qatar. Organic Geochemistry 102, 14-29.

Spadafora, A., Perri, E., Mckenzie, J. A. and Vasconcelos, C. (2010). Microbial biomineralization processes forming modern $\mathrm{Ca}: \mathrm{Mg}$ carbonate stromatolites. Sedimentology 57, 27-40.

Spring, S., Brinkmann, N., Murrja, M., Spröer, C., Reitner, J. and Klenk, H.-P. (2015). High Diversity of Culturable Prokaryotes in a Lithifying Hypersaline Microbial Mat. Geomicrobiology Journal 32, 332-346.

Suarez-Gonzalez, P., Hause-Reitner, D., Shen, Y., Schäfer, N. and Reitner, J. (2017). Ooidlike particles growing in situ within microbial mats (Kiritimati Island, Central Pacific). University of Science and Technology of China Press, 246-248.

Summons, R. E. (1987), Branched alkanes from ancient and modern sediments: Isomer discrimination by GC/MS with multiple reaction monitoring. Organic Geochemistry 11, 281-289.

Summons, R. E., Albrecht, P., McDonald, G. and Moldowan, J. M. (2008). Molecular Biosignatures. Space Sci Rev 135, 133-159.

Summons, R. E., Bradley, A. S., Jahnke, L. L. and Waldbauer, J. R. (2006). Steroids, triterpenoids and molecular oxygen. Philosophical transactions of the Royal Society of London. Series B, Biological sciences 361, 951-968.

Summons, R. E., Brassell, S. C., Eglinton, G., Evans, E., Horodyski, R. J., Robinson, N. and Ward, D. M. (1988b). Distinctive hydrocarbon biomarkers from fossiliferous sediment of the Late Proterozoic Walcott Member, Chuar Group, Arizona. Geochimica et Cosmochimica Acta 52, 2625-2637.

Summons, R. E. and Capon, R. J. (1988c). Fossil steranes with unprecedented methylation in ring-A. Geochimica et Cosmochimica Acta 52, 2733-2736. 
Summons, R. E. and Capon, R. J. (1991). Identification and significance of $3 \beta$-ethyl steranes in sediments and petroleum. Geochimica et Cosmochimica Acta 55, 2391-2395.

Summons, R. E. and Jahnke, L. L. (1992). Hopenes and hopanes methylated in ring-A: correlation of the hopanoids of extant methylotrophic bacteria with their fossil analogues. Biomarkers in Sediments and Petroleum, 182-200.

Summons, R. E., Jahnke, L. L., Hope, J. M. and Logan, G. A. (1999). 2-Methylhopanoids as biomarkers for cyanobacterial oxygenic photosynthesis. Nature 400, 554-557.

Summons, R. E. and Powell, T. G. (1986). Chlorobiaceae in Palaeozoic seas revealed by biological markers, isotopes and geology. Nature 319, 763-765.

Summons, R. E., Powell, T. G. and Boreham, C. J. (1988a). Petroleum geology and geochemistry of the middle Proterozoic McArthur Basin, Northern Australia: III. Composition of extractable hydrocarbons. Geochimica et Cosmochimica Acta 52, 17471763.

ten Haven, H. L., de Leeuw, J. W., Rullkötter, J. and Sinninghe Damsté, J. S. (1987). Restricted utility of the pristane/phytane ratio as a palaeoenvironmental indicator. Nature 330, 641-643.

Thiel, V., Blumenberg, M., Pape, T., Seifert, R. and Michaelis, W. (2003) Unexpected occurrence of hopanoids at gas seeps in the Black Sea. Organic Geochemistry 34, 81-87.

Thiel, V., Jenisch, A., Woerheide, G., Loewenberg, A., Reitner, J. and Michaelis, W. (1999a). Mid-chain branched alkanoic acids from "living fossil" demosponges: a link to ancient sedimentary lipids? Organic Geochemistry 30, 1-14.

Thiel, V., Peckmann, J., Richnow, H. H., Luth, U., Reitner, J. and Michaelis, W. (2001). Molecular signals for anaerobic methane oxidation in Black Sea seep carbonates and a microbial mat. Marine Chemistry 73, 97-112.

Thiel, V., Peckmann, J., Seifert, R., Wehrung, P., Reitner, J. and Michaelis, W. (1999b). Highly isotopically depleted isoprenoids: Molecular markers for ancient methane venting. Geochimica et Cosmochimica Acta 63, 3959-3966.

Tice, M. M. and Lowe, D. R. (2004). Photosynthetic microbial mats in the 3,416-Myr-old ocean. Nature 431, 549-552.

Treibs, A. (1936). Chlorophyll- und Häminderivate in organischen Mineralstoffen. Angewandte Chemie 49, 682-686.

Trichet, J., Défarge, C., Tribble, J., Tribble, G. and Sansone, F. (2001). Christmas Island lagoonal lakes, models for the deposition of carbonate-evaporite-organic laminated sediments. Sedimentary Geology 140, 177-189.

Valencia, M. (1977). Christmas Island (Pacific ocean): Reconnaissance geologic observations. Atoll Research Bulletin 197, 1-19.

van den Ende, F. P. and van Gemerden, H. (1994). Relationships between functional groups of organisms in microbial mats. In Microbial Mats (eds. L. J. Stal and P. Caumette).

Springer Berlin Heidelberg. Berlin, Heidelberg, pp. 339-352. 
van der Meer, M. (2002). Structure and isotopic composition of bacterial lipids: Insights into distribution and carbon acquisition mechanisms of bacteria in hot spring microbial mats. $\mathrm{PhD}$ thesis, Universitaet Utrecht, 1-91.

van der Meer, M. T., Schouten, S., van Dongen, B. E., Rijpstra, W. I., Fuchs, G., Sinninghe Damsté J., de Leeuw, J. W. and Ward, D. M. (2001). Biosynthetic controls on the ${ }^{13} \mathrm{C}$ contents of organic components in the photoautotrophic bacterium Chloroflexus aurantiacus. The Journal of biological chemistry 276, 10971-10976.

van der Meer, M. T. J., Schouten, S. and Sinninghe Damsté, J. S. (1998). The effect of the reversed tricarboxylic acid cycle on the $13 \mathrm{C}$ contents of bacterial lipids. Organic Geochemistry 28, 527-533.

van Gemerden, H. (1993). Microbial mats: A joint venture. Marine Geology 113, 3-25.

van Kaam-Peters, H. M.E., Koester, J., van der Gaast, S. J., Dekker, M., de Leeuw, J. W. and Sinninghe Damsté, J. S. (1998). The effect of clay minerals on diasterane/sterane ratios. Geochimica et Cosmochimica Acta 62, 2923-2929.

van Maldegem, L. M., Sansjofre, P., , Weijers, J.W. H., Wolkenstein, K., Strother, P. K., Wörmer, L., Hefter, J., Nettersheim, B. J., Hoshino, Y., Schouten, S., Sinninghe Damsté, J. S., Nath, N., Griesinger, C., Kuznetsov, N. B., Elie, M., Elvert, M., Tegelaar, E., Gleixner, G. and Hallmann, C. (2019). Bisnorgammacerane traces predatory pressure and the persistent rise of algal ecosystems after Snowball Earth. Nature communications 10, 1-11.

van Zuilen, M. A., Lepland, A. and Arrhenius, G. (2002). Reassessing the evidence for the earliest traces of life. Nature 418, 627-630.

Vance, D., Archer, C., Little, S. H., Köbberich, M. and Souza, G. F. de (2017). The oceanic cycles of the transition metals and their isotopes. Acta Geochim 36, 359-362.

Vandenbroucke, M. and Largeau, C. (2007). Kerogen origin, evolution and structure. Organic Geochemistry 38, 719-833.

Volkman, J. K. and Maxwell, J. R. (1986). Acyclic isoprenoids as biological markers. R.B. Johns (Ed.), Biological Markers in the Sedimentary Record, Elsevier (1986), pp. 1-42.

Volkman, J. K. (1986). A review of sterol markers for marine and terrigenous organic matter. Organic Geochemistry 9, 83-99.

Volkman, J. K. (2003). Sterols in microorganisms. Appl Microbiol Biotechnol 60, 495-506.

Volkman, J. K. (2005). Sterols and other triterpenoids. Organic Geochemistry 36, 139-159.

Volkman, J. K. (2006). Lipid markers for marine organic matter. The handbook of Environmental Chemistry 2, 27-70.

Volkman, J. K., Barrett, S. M., Dunstan, G. A. and Jeffrey, S. W. (1993). Geochemical significance of the occurrence of dinosterol and other 4-methyl sterols in a marine diatom. Organic Geochemistry 20, 7-15. 
Volkman, J. K., Johns, R. B., Gillan, F. T., Perry, G. J., Bavor, H. J. and JR (1980). Microbial lipids of an intertidal sediment-I.Fatty acids and hydrocarbons. Geochimica et Cosmochimica Acta 44, 1133-1143.

Volkman, J. K., Kearney, P. and Jeffrey, S. W. (1990). A new source of 4-methyl sterols and $5 \alpha(\mathrm{H})$-stanols in sediments: prymnesiophyte microalgae of the genus Pavlova. Organic Geochemistry 15, 489-497.

Wakeham, S. G. and Beier, J. A. (1991). Fatty acid and sterol biomarkers as indicators of particulate matter source and alteration processes in the Black Sea. Deep Sea Research Part A. Oceanographic Research Papers 38, S943-S968.

Wakeham, S. G., Freeman, K. H., Pease, T. K. and Hayes, J. M. (1993). A photoautotrophic source for lycopane in marine water columns. Geochimica et Cosmochimica Acta 57, 159165.

Wakeham, S. G., Sinninghe Damsté, J. S., Kohnen, M. E. L. and de Leeuw, J. W. (1995). Organic sulfur compounds formed during early diagenesis in Black Sea sediments. Geochimica et Cosmochimica Acta 59, 521-533.

Waldbauer, J. R., Newman, D. K. and Summons, R. E. (2011). Microaerobic steroid biosynthesis and the molecular fossil record of Archean life. Proc Natl Acad Sci USA 108, 13409-13414.

Wang, T.-G., Li, M., Wang, C., Wang, G., Zhang, W., Shi, Q. and Zhu, L. (2008). Organic molecular evidence in the Late Neoproterozoic Tillites for a palaeo-oceanic environment during the snowball Earth era in the Yangtze region, southern China. Precambrian Research 162, 317-326.

Welander, P. V. and Summons, R. E. (2012). Discovery, taxonomic distribution, and phenotypic characterization of a gene required for 3-methylhopanoid production. Proc Natl Acad Sci USA 109, 12905-12910.

Wentworth, C. K. (1931). Geology of the Pacific equatorial islands. The Museum, Honolulu, Hawaii.

Wester, L. (1985). Checklist of the vascular plants of the Northern Line Islands. Atoll Research Bulletin, 1-38.

Woodroffe, C. D. and McLean, R. F. (1998). Pleistocene morphology and Holocene emergence of Christmas (Kiritimati) Island, Pacific Ocean. Coral Reefs 17, 235-248.

Yano, K., Akihisa, T., Tamura, T. and Matsumoto, T. (1992). Four 4 $\alpha$-methylsterols and triterpene alcohols from Neolitsea Aciculata. Phytochemistry 31, 2093-2098.

Zerkle, A. L., Scheiderich, K., Maresca, J. A., Liermann, L. J. and Brantley, S. L. (2011). Molybdenum isotope fractionation by cyanobacterial assimilation during nitrate utilization and $\mathrm{N}_{2}$ fixation. Geobiology 9, 94-106.

Zhu, X. K., Guo, Y., Williams, R.J.P., O'Nions, R. K., Matthews, A., Belshaw, N. S., Canters, G. W., de Waal, E. C., Weser, U., Burgess, B. K. and Salvato, B. (2002). Mass fractionation processes of transition metal isotopes. Earth and Planetary Science Letters 200, 47-62. 
Zundel M. and Rohmer M. (1985) Prokaryotic triterpenoids. Eur. J. Biochem. 150, 23-27. 
-Chapter 2-

\title{
Tracing the fate of steroids through a hypersaline microbial mat $\underline{\text { (Kiritimati, Kiribati/Central Pacific) }}$
}

(published in Geobiology)

Yan Shen, Volker Thiel, Jan-Peter Duda, Joachim Reitner

\begin{abstract}
Eukaryotic steranes are typically absent or occur in very low concentrations in Precambrian sedimentary rocks. However, it is as yet unclear whether this may reflect low source inputs or a preservational bias. For instance, it has been proposed that eukaryotic lipids were profoundly degraded in benthic microbial mats that were ubiquitous prior to the advent of vertical bioturbation in the Cambrian ("mat-seal effect"). It is therefore important to test the microbial turnover and degradation of eukaryotic steroids in real-world microbial mats. Here we assessed steroid inventories in different layers of a microbial mat from a hypersaline lake on Kiritimati (Central Pacific). Various eukaryote-derived $\mathrm{C}_{27}-\mathrm{C}_{30}$ steroids were detected in all mat layers. These compounds most likely entered the mat system as unsaturated sterols from the water column or the topmost mat, and were progressively altered during burial in the deeper, anoxic mat layers over c. $10^{3}$ years. This is reflected by increasing proportions of saturated sterols and sterenes, as well as the presence of thiosteranes in certain horizons. Sterol alteration can partly be assigned to microbial transformation but is also due to chemical reactions promoted by the reducing environment in the deeper mat layers. Notably, however, compounds with a sterane skeleton were similarly abundant in all mat layers and their absolute concentrations did not show any systematic decrease. Decreasing steroid/hopanoid ratios with depth therefore rather indicate a progressive "dilution" by lipids derived from heterotrophic bacteria. Further, pyrolysis revealed that steroids, in contrast to hopanoids, were not sequestered into non-extractable organic matter. This may lead to a preservational bias against steroids during later stages of burial. Taken together, steroid preservation in the
\end{abstract}


microbial mat is not only controlled by heterotrophic degradation, but rather reflects a complex interplay of taphonomic processes.

Keywords: eukaryotes, mat-seal effect, organic biomarkers, preservational pathways, pyrolysis, taphonomy

\subsection{Introduction}

Microbial mats are mm- to $\mathrm{cm}$ - thick benthic communities with a clear vertical zonation of different functional microbial groups (Van den Ende and Van Gemerden, 1994; Van Gemerden, 1993). Inorganic carbon assimilation, commonly by photoautotrophs, leads to an accumulation of biomass, which is subsequently transformed and degraded by aerobic and anaerobic heterotrophic prokaryotes in deeper mat layers. Hence, only a minor fraction of the carbon becomes preserved as residual organic matter and/or carbonate deposits. In the Proterozoic, prior to the emergence of vertical bioturbation at the Precambrian-Cambrian transition ("agronomic revolution" or "substrate revolution"; Bottjer, Hagadorn and Dornbos, 2000; Seilacher, 1999; Seilacher and Pflüger, 1994), microbial mats probably have been more widespread in marine environments than in the Phanerozoic (Grotzinger and Knoll, 1999; Riding, 2011; Walter, 1976) and may have been a major factor influencing global biogeochemical cycles (Canfield and Des Marais, 1993; Canfield, Sørensen and Oren, 2004; Hoehler, Bebout and Des Marais, 2001).

Eukaryote-derived steranes are typically absent or occur in very low concentrations in Precambrian sedimentary rocks. The scarcity of sedimentary steranes may be explained by a limited ecological significance of eukaryotic algae and thus, a minor contribution to primary production (Anbar and Knoll, 2002; Knoll, Summons, Waldbauer and Zumberge, 2007; Blumenberg et al., 2012), and/or thermal destruction (e.g. in the 1.64 Ga Barney Creek Formation; Summons, Powell and Boreham, 1988). Alternatively, however, this feature might reflect a taphonomic bias against the preservation of eukaryotic lipids. Prior to the advent of vertical bioturbation at the Ediacaran-Cambrian transition, pervasive benthic microbial mats may have formed a mechanical and biochemical barrier against eukaryotic biomass derived from the water column and the upper mat layers ("mat-seal effect", Pawlowska, Butterfield and Brocks, 2013). In this scenario, signals from heterotrophic microorganisms living within the deeper mat layers would be preferentially preserved, thus leading to a suppression of the primary ecological signal. 
The atoll of Kiritimati (Republic of Kiribati, Central Pacific: Figure 2.1) is a perfect study site for testing preservational pathways of steroids in microbial mats. The island contains c. 500 brackish to hypersaline lakes with well-developed microbial mats (Trichet et al., 2001; Valencia, 1977). Several of these mats have successfully been characterized by using lipid biomarkers (Blumenberg et al., 2013; Blumenberg, Thiel and Reitner, 2015; Bühring et al., 2009). Increased hopane/sterane ratios in the non-extractable lipids from a Lake 2 mat suggest that steroids may indeed suffer from a potential mat-seal effect (Blumenberg, Thiel and Reitner, 2015). However, the detailed preservation pathways of eukaryote-derived steroidal compounds have not been assessed in any of the Kiritimati mats so far.

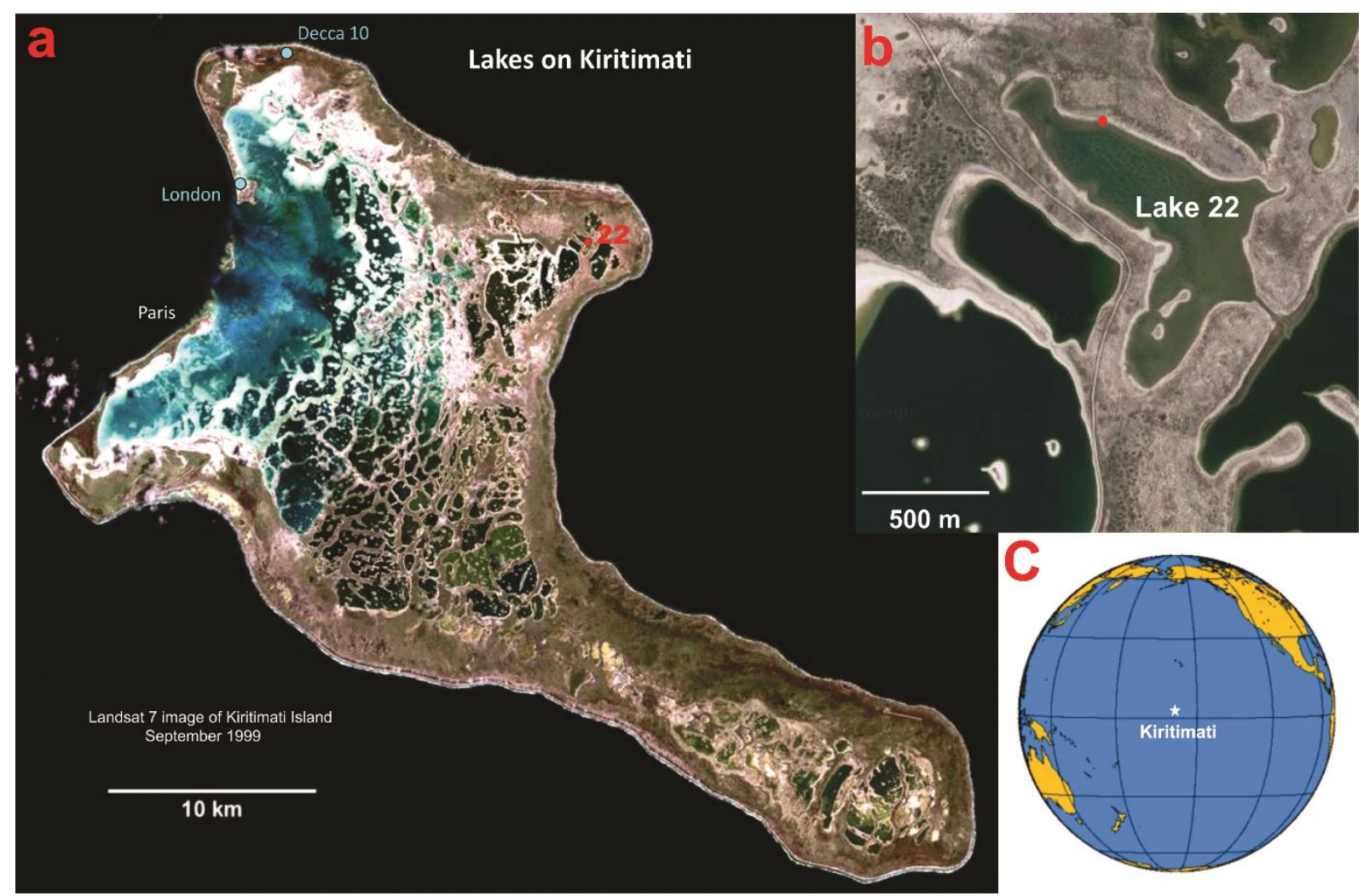

Figure 2.1 (a) Satellite view of Kiritimati atoll (Landsat 7 image, 1999); (b) Enlarged view showing the study site (Lake 22; red dot: sampling site; Google Earth image, 2017); (c) Map showing the location of Kiritimati in the Central Pacific (modified from Wikipedia).

Here we trace the fate of eukaryotic steroids in an active microbial mat from the hypersaline Lake 22 at the northern part of the Kiritimati atoll (Figure 2.1). A detailed analysis of steroid assemblages at different depths of the mat allows to elucidate the taphonomy of these biomarkers after their introduction into the microbial mat system. 


\subsection{Materials and methods}

\subsubsection{Location and samples}

The atoll of Kiritimati (formerly Christmas Island) is located close to the Equator at $1^{\circ} 55^{\prime} \mathrm{N}$, $157^{\circ} 25^{\prime} \mathrm{W}$ in the Central Pacific (Figure 2.1). It is part of the Northern Line Islands of the Republic of Kiribati, the largest coral atoll in the world (surface area c. $360 \mathrm{~km}^{2}$ ). Kiritimati has an arid climate $(-2 \mathrm{~mm} / \mathrm{d}$ long term net rainfall minus evaporation), and harbors approximately 500 brackish to hypersaline lakes (Valencia, 1997; Trichet et al., 2001). Substantial differences can be observed between the lakes in terms of salinities (e.g. 69\%o and 202\% in two adjacent lakes; Trichet et al., 2001), colors of the top sediments (gray, red, orange, pink), and water levels (up to $1 \mathrm{~m}$ between adjacent lakes; Valencia, 1977). As a consequence, mats are highly diverse and exhibit fundamental variations in microbial community composition between different lakes (cf. Blumenberg et al., 2013; Blumenberg, Thiel and Reitner, 2015; Bühring et al., 2009; Ionescu et al., 2015; Schneider et al., 2013).

Kiritimati is influenced by the El Niño-Southern Oscillation (ENSO). Recharge of the lakes occurs during El Niño wet events, when heavy rains and high sea levels induce flooding and a decrease in lake salinities. During La Niña dry events, in turn, reduced precipitation and higher evaporation cause droughts and increased lake salinities. The biota prevailing in the vicinity of the lakes consists of the land crab Gecarcoidea natalis, the mangrove Rhizophora mucronata, the parasitic climber Cassytha filiformis, the grass Lepturus repens, and the ironwood Pemphis acidula. Important faunal elements of the lakes comprise the brine shrimp Artemia and occasionally the milkfish Chanos chanos (Saenger, Miller, Smittenberg and Sachs, 2006).

Microbial mats from the Lake 22 at the northern part of the Kiritimati atoll (Figure 2.1) are of different visual appearance as those described from other ponds on the island (cf. Bühring et al., 2009; Arp et al., 2012; Blumenberg et al., 2013; Blumenberg, Thiel and Reitner, 2015; Ionescu et al., 2015; Schneider et al., 2013) and have not been investigated so far. The water salinity in this lake declined from 149\% in 1988 to $140 \%$ in 1990 (Trichet et al., 2001), and 132\% in 2002 (Arp et al., 2012), but increased to 250\% in 2011 (own data, unpublished), probably indicating prevailing ENSO activity. The analyzed mat was collected during a field trip in March 2011 at the margin of the lake $\left(1^{\circ} 58.154^{\prime} \mathrm{N}, 157^{\circ} 20.035^{\prime} \mathrm{W}\right.$; water depth c. 0.2 $\mathrm{m}$; Figure 2.1). A cube-shaped sample was cut out with a knife, immediately cooled at $4{ }^{\circ} \mathrm{C}$ in the field, and later frozen at $-20^{\circ} \mathrm{C}$ until further processing in the home laboratory. For this 
study, six sub-samples, each representing a $0.5-1 \mathrm{~cm}$ thick mat layer, were taken from different depths of the mat profile (12 cm total thickness; Figure 2.2).

\subsubsection{Accelerator Mass Spectrometry (AMS) dating}

AMS ${ }^{14} \mathrm{C}$ dating was performed in the Laboratory of Ion Beam Physics at the ETH Zurich, Switzerland (see http://www.Ams.ethz.ch/ for details). The analyses were conducted on small aragonite aggregates which were formed within the extracellular polymeric substances (EPS) of the microbial mat. The obtained ${ }^{14} \mathrm{C}$ ages ( \pm 40 years) have been corrected for $\delta^{13} \mathrm{C}$ on the basis of ${ }^{14} \mathrm{C}$ concentrations in the sample and are provided in yrs BP (before present; i.e. before 1950, the start of worldwide nuclear bomb tests).

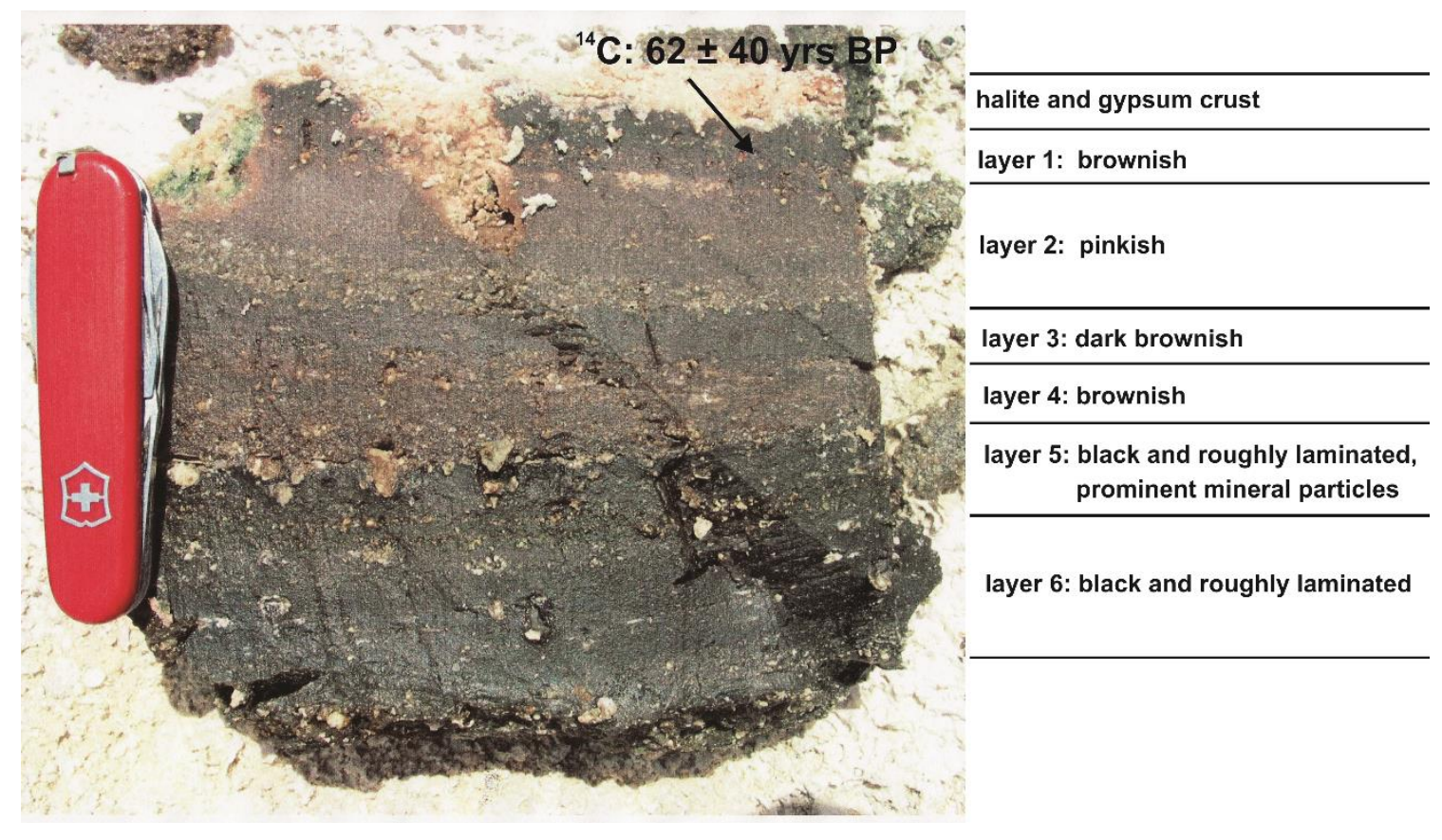

Figure 2.2 Analyzed microbial mat from Lake $22(12 \mathrm{~cm}$ thickness in total), indicating the position of the six sampled layers. ${ }^{14} \mathrm{C}$ AMS dating of carbonate aggregates from the top of the mat (layer 1, arrow) yielded an age of $62 \pm 40 \mathrm{yrs}$ BP.

\subsubsection{Bulk analysis}

Homogenized aliquots of the freeze-dried samples were subjected to $\mathrm{C} / \mathrm{N} / \mathrm{S}$ analysis, using a Hekatech EA $3000 \mathrm{CNS}$ analyzer. To determine the contents of organic carbon $\left(\mathrm{C}_{\text {org }}\right)$ and carbonate carbon $\left(\mathrm{C}_{\mathrm{carb}}\right)$ simultaneously, the samples were also analyzed with a LECO RC 612 Multiphase-Carbon-Analyzer. Freeze-dried ground mat sample was placed in a quartz combustion boat and heated from 120 to $1000^{\circ} \mathrm{C}$ in a stream of $\mathrm{O}_{2}(750 \mathrm{ml} / \mathrm{min})$. The timeand temperature-resolved $\mathrm{CO}_{2}$ release was detected with an infrared absorption cell. 


\subsubsection{Extraction and derivatization}

$1 \mathrm{~g}$ of freeze dried homogenized sample from each layer was suspended in dichloromethane (DCM)-extracted millipore water. To remove the carbonate, $\mathrm{HCl}(10 \%)$ was added dropwise until $\mathrm{CO}_{2}$ development ceased. The decalcified samples were washed with water until a neutral $\mathrm{pH}$ was reached. Lipid biomarkers were extracted in the following steps: (i) $15 \mathrm{ml}$ $\mathrm{DCM} /$ methanol (MeOH) mixture (2:1, V:V), (ii) $15 \mathrm{ml} \mathrm{DCM} / \mathrm{MeOH}$ mixture (3:1, V:V), (iii) $15 \mathrm{ml} \mathrm{DCM}$, and (iv) $15 \mathrm{ml} n$-hexane (20 min ultrasonication, respectively). The resulting total lipid extracts were combined and carefully reduced to $1 \mathrm{ml}$ in a gentle stream of $\mathrm{N}_{2}$.

To make ester-bound and free carboxylic acids GC-amenable, a mixture of trimethylchlorosilane (TMCS)/MeOH $(1: 9, \mathrm{~V}: \mathrm{V})$ was added to a $10 \%$ aliquot of the total lipid extract $\left(80^{\circ} \mathrm{C}, 60 \mathrm{~min}\right)$. The resulting carboxylic acid methyl esters and remaining neutral lipids (including sterols and steroid hydrocarbons) were extracted from the reaction mixture by vigorous shaking with $3 \times 1 \mathrm{ml} n$-hexane. The extracts were combined and evaporated to near-dryness under a gentle stream of $\mathrm{N}_{2}$, re-dissolved in $n$-hexane, and analyzed by gas chromatography-mass spectrometry (GC-MS). To make alcohols (including sterols) GCamenable, a $20 \%$ aliquot of the total lipid extract was silylated using BSTFA (N,Obis(trimethylsilyl)trifluoroacetamide) containing $5 \%(\mathrm{~V}: \mathrm{V})$ TMCS as a catalyzer $\left(70^{\circ} \mathrm{C}, 60\right.$ min). The resulting trimethylsilyl (TMS-) derivatives were dried, re-dissolved in $n$-hexane, and analyzed by gas chromatography-mass spectrometry (GC-MS).

\subsubsection{Gas chromatography-mass spectrometry (GC-MS)}

GC-MS analyses were carried out using a Thermo Fisher Trace 1300 Series GC coupled to a Thermo Fisher Quantum XLS Ultra MS. The GC was equipped with a capillary column (Phenomenex Zebron ZB-5, $30 \mathrm{~m}$ length, $0.1 \mu \mathrm{m}$ film thickness, inner diameter $0.25 \mathrm{~mm}$ ). The derivatized extracts were injected into a splitless injector and transferred to the GC column at $270^{\circ} \mathrm{C}$. The carrier gas was helium at a flow rate of $1.5 \mathrm{ml} \mathrm{min}{ }^{-1}$. The GC oven temperature was ramped from $80^{\circ} \mathrm{C}(1 \mathrm{~min})$ to $310^{\circ} \mathrm{C}$ at $5^{\circ} \mathrm{C} \mathrm{min}^{-1}$ (held $20 \mathrm{~min}$ ). Electron ionization mass spectra were recorded in full scan mode at $70 \mathrm{eV}$, a mass range of m/z 50-600 and a scan time of $0.42 \mathrm{~s}$. $n$-eicosane-D42 was used as an internal standard for quantification.

\subsubsection{Pyrolysis-gas chromatography-mass spectrometry (Py-GC-MS)}

Extraction residues were pyrolysed on a fast-heating Pt-filament using a Pyrola 2000 pyrolysis device (Pyrolab SB) coupled to a Varian CP3800 GC and a Varian 1200L MS. The 
filament, loaded with c. $5 \mathrm{mg}$ of sample powder and $120 \mathrm{ng}$ of an internal standard ( $n$ eicosane-D42), was heated in $2 \mathrm{~ms}$ to $560^{\circ} \mathrm{C}$ (held $30 \mathrm{~s}$ ). Pyrolysis products were flushed from the chamber into the $\mathrm{GC}$ split injector $\left(305^{\circ} \mathrm{C}\right)$ and transferred to the $\mathrm{GC}$ column using a split rate of 75. The GC instrument was equipped with a Phenomenex Zebron ZB-5 capillary column (30 m, $0.1 \mu \mathrm{m}$ film thickness, inner diameter $0.32 \mathrm{~mm})$. The carrier gas was He at a flow rate of $1.4 \mathrm{ml} \mathrm{min}^{-1}$. The $\mathrm{GC}$ oven temperature was ramped from $40^{\circ} \mathrm{C}(1 \mathrm{~min})$ to $330^{\circ} \mathrm{C}$ at $10^{\circ} \mathrm{C} \mathrm{m^{-1 }}$ and held for $13 \mathrm{~min}$. Electron ionization mass spectra were recorded in full scan mode at an electron energy of $70 \mathrm{eV}$, a mass range of $\mathrm{m} / \mathrm{z} 50$ to 500 , and a scan time of $0.5 \mathrm{~s}$.

\subsection{Results}

\subsubsection{Visual appearance of the microbial mat}

The investigated microbial mat was situated close to the mouth of a small creek transporting lesser saline shallow groundwater into the highly saline lake basin. In the mixing zone of both water masses, a high microbial productivity resulted in the formation of a thick, blackish- to brownish colored microbial mat.

The studied microbial mat has a thickness of about $12 \mathrm{~cm}$ and is subdivided into two major facies zones. The lower, older portion (layers 5-6; Figure 2.2) is c. $5 \mathrm{~cm}$ thick, has a blackish color, and is coarsely laminated. The c. 1-2 cm thick laminae contain differently shaped carbonate particles (small seed- and dumbbell type crystals, crystal aggregates, as well as peloidal aggregates and spherical bodies) of varying size $(10 \mu \mathrm{m}-1 \mathrm{~mm})$. EDX- and Raman analyses revealed mainly aragonite and rarely $\mathrm{Mg}$-calcite and proto-dolomite mineralogies. These particles were likely formed through EPS degradation (cf. Arp et al., 2012; Ionescu et al., 2015). Additionally, some sulfate particles (e.g. gypsum) were detected. At the facies boundary (between layer 4 and 5, see Figure 2.2), mineralized particles are significantly enriched. The origin of the facies boundary is unknown, but may be related to changes in precipitation due to El Niño events. Carbonate particles from a corresponding depth in an immediately adjacent mat yielded a ${ }^{14} \mathrm{C}$ age of $1,291 \pm 40 \mathrm{yrs} \mathrm{BP}$.

The upper facies (layers 1-4; Figure 2.2) has a thickness of c. $7 \mathrm{~cm}$ and exhibits again a rough 1-2 cm layering. In contrast to the older facies section, the color is more brownish to pinkish, except layer 3 which is slightly darker. The mat has an irregular top layer, which shows V-shaped fractures with buckled margins, similar to Tepee fabrics known from other evaporitic settings. The microbial mat is covered by a crust of halite and gypsum. The upper 
facies contains a variety of mineral particles similar to the lower facies, probably also formed through EPS degradation (cf. Arp et al., 2012; Ionescu et al., 2015). In addition to the mineralisates, remains of crustaceans (Artemia sp.), bones and scales of fishes ("milkfish" Chanos chanos, and Tilapia sp.), rare Miliolid foraminifers, algae and land plants were observed. ${ }^{14} \mathrm{C}$ AMS analyses on carbonate particles from layer 1 revealed a radiometric age of $62 \pm 40 \mathrm{yrs}$ BP.

\subsubsection{Bulk geochemical data}

Bulk geochemical data for individual mat layers showed no significant trend (Table 2.1). The highest amount of $\mathrm{C}_{\text {org }}(15.5 \%)$ was observed in layer 1, while the other mat layers showed somewhat lower but quite constant values (7.5 to $10.6 \%$ ). The $\mathrm{CaCO}_{3}$ contents generally showed a narrow range between $20-25 \%$ throughout the mat, with a somewhat higher abundance (30.3\%) in layer 5. $\mathrm{N}$ and $\mathrm{S}$ ranged from $0.9-2.1 \%$, and $1.9-3.3 \%$, respectively, with highest values occurring in the topmost mat layer 1 .

Table 2.1 Bulk geochemical data for the microbial mat layers.

\begin{tabular}{|c|c|c|c|c|c|c|}
\hline Layer & $\mathrm{C}_{\text {tot }}(\%)$ & $\mathrm{C}_{\text {org }}(\%)$ & $\mathrm{C}_{\text {carb }}(\%)$ & $\begin{array}{c}\mathrm{CaCO}_{3} \\
(\%)\end{array}$ & $\mathrm{N}_{\text {tot }}(\%)$ & $\mathrm{S}_{\text {tot }}(\%)$ \\
\hline 1 & 17.9 & 15.5 & 2.4 & 20.3 & 2.1 & 3.3 \\
\hline 2 & 11.6 & 9.1 & 2.6 & 21.5 & 1.0 & 2.7 \\
\hline 3 & 10.5 & 7.5 & 3.0 & 24.8 & 0.9 & 2.1 \\
\hline 4 & 10.5 & 7.6 & 2.9 & 24.2 & 0.9 & 2.1 \\
\hline 5 & 12.7 & 9.0 & 3.6 & 30.3 & 1.1 & 1.9 \\
\hline 6 & 13.0 & 10.6 & 2.4 & 20.1 & 1.2 & 2.1 \\
\hline
\end{tabular}

\subsubsection{Quantitative distribution of steroids}

The most abundant steroids were saturated sterols $\left(\Delta^{0}\right.$, stanols $)$, in particular $5 \alpha$-cholestan-3 $\beta$ -

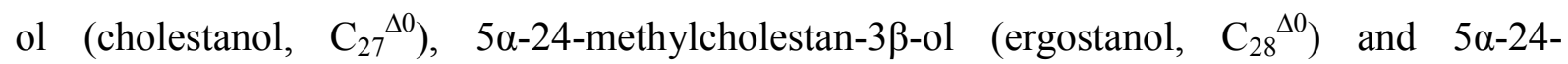
ethylcholestan-3 $\beta$-ol (stigmastanol, $\mathrm{C}_{29}{ }^{\Delta 0}$; Figure 2.3, Table 2.2). The stanols showed an overall increase in concentration with depth. The highest concentrations of cholestanol and stigmastanol appeared in layer 6 (26.6 and $12.6 \mu \mathrm{g} / \mathrm{g}$ dry mat, respectively), while the highest abundance of ergostanol was found in layer $2(15.5 \mu \mathrm{g} / \mathrm{g}$ dry mat). In addition, an isomer of

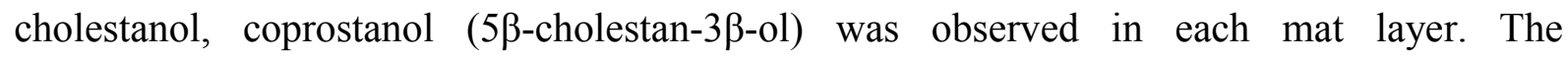
coprostanol also showed an increased abundance with depth, with the highest amount appearing in layer $5(7.0 \mu \mathrm{g} / \mathrm{g}$ dry mat). 
Unsaturated sterols (stenols) accounted for another major portion of the total steroids.

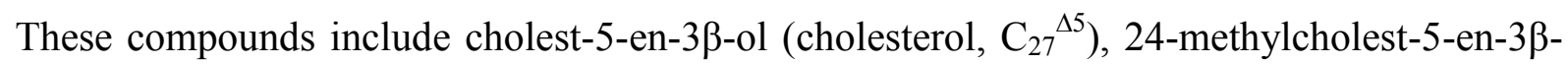
ol (campesterol, $\mathrm{C}_{28}{ }^{\Delta 5}$ ), and 24-ethylcholest-5-en-3 $\beta$-ol ( $\beta$-sitosterol, $\mathrm{C}_{29}{ }^{{ }^{5}}$; Figure 2.3, Table 2.2). Unlike the stanols, the stenols showed an overall decrease in abundance with depth. For instance, cholesterol was most abundant in layer $2(8.1 \mu \mathrm{g} / \mathrm{g}$ dry mat $)$ and showed lowest amounts in layer $4(1.5 \mu \mathrm{g} / \mathrm{g}$ dry mat) and layer $6(1.6 \mu \mathrm{g} / \mathrm{g}$ dry mat). Similarly, the highest concentration of 24-ethylcholesta-5,22-dien-3 $\beta$-ol (stigmasterol, $\mathrm{C}_{29}{ }^{\Delta 5,22}$ ) was present in layer $2(9.8 \mu \mathrm{g} / \mathrm{g}$ dry mat) and the lowest value was found in layer $6(2.1 \mu \mathrm{g} / \mathrm{g}$ dry mat $)$.

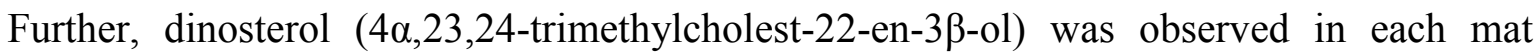
layer. This compound did not follow the depth trend of the other stenols, as the highest amount $(9.3 \mu \mathrm{g} / \mathrm{g}$ dry mat) was observed in layer 6 , while the lowest appeared in layer 2 (2.2 $\mu \mathrm{g} / \mathrm{g}$ dry mat; Table 2.2).

$\mathrm{C}_{27}-\mathrm{C}_{29}$ sterenes were detected in each mat layer, including 5 $\alpha$-cholest-2-ene, $5 \alpha-24$ methylcholest-2-ene, and 5 $\alpha$-24-ethylcholest-2-ene. In addition, a $\mathrm{C}_{27}$ thiosterane $(5 \alpha-$ cholestane-3 $\beta$-thiol, see Figure A.1 for mass spectrum) was exclusively detected in layer 5 $(29.1 \mu \mathrm{g} / \mathrm{g}$ dry mat; $\underline{\text { Table } 2.2})$. 
Table 2.2 Concentrations of steroids in the microbial mat layers ( $\mu \mathrm{g} / \mathrm{g}$ dry mat; $\mathrm{n} . \mathrm{d} .=$ not determined).

\begin{tabular}{|c|c|c|c|c|c|c|c|c|c|c|c|c|c|c|c|}
\hline $\begin{array}{l}\text { Trivial } \\
\text { names }\end{array}$ & - & - & - & - & Coprostanol & Cholesterol & Cholestanol & Brassicasterol & Thiosterane & Campesterol & Ergostanol & Stigmasterol & $\beta$-sitosterol & Stigmastanol & Dinosterol \\
\hline Compound & $\begin{array}{l}5 \alpha \text {-cholest- } \\
\text { 2-ene }\end{array}$ & $\begin{array}{l}\text { Unknown } \\
\text { cholestene }\end{array}$ & $\begin{array}{c}5 \alpha-24- \\
\text { methylchole } \\
\text { st-2-ene }\end{array}$ & $\begin{array}{c}5 \alpha-24- \\
\text { ethylcholest } \\
-2 \text {-ene }\end{array}$ & $\begin{array}{c}5 \beta \text {-cholestan- } \\
3 \beta \text {-ol }\end{array}$ & 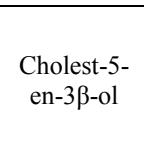 & $\begin{array}{c}5 \alpha- \\
\text { cholestan- } \\
3 \beta-o l\end{array}$ & 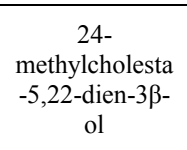 & $\begin{array}{c}5 \alpha- \\
\text { cholestane- } \\
3 \beta \text {-thiol }\end{array}$ & 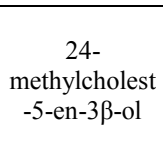 & 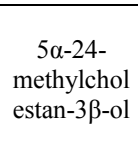 & 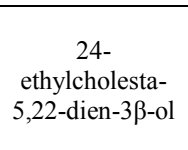 & 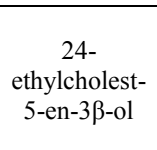 & $\begin{array}{c}5 \alpha-24- \\
\text { ethylcholestan } \\
-3 \beta-o l\end{array}$ & 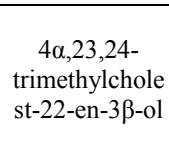 \\
\hline 1 & 1.0 & 0.3 & 0.7 & 0.4 & 2.6 & 1.9 & 14.8 & 3.4 & n.d. & 7.5 & 9.2 & 2.9 & 2.8 & 6.9 & 4.8 \\
\hline 2 & 2.1 & 1.1 & 1.3 & 1.2 & 5.4 & 8.1 & 21.7 & 14.7 & n.d. & 23.0 & 15.5 & 9.8 & 9.1 & 12.5 & 2.2 \\
\hline 3 & 1.3 & 0.2 & 0.6 & 0.6 & 3.2 & 2.6 & 14.3 & 2.4 & n.d. & 5.3 & 6.6 & 2.5 & 2.9 & 6.4 & 2.9 \\
\hline 4 & 1.6 & 0.3 & 0.6 & 0.4 & 3.5 & 1.5 & 25.3 & 1.0 & n.d. & 6.3 & 12.0 & 3.7 & 3.5 & 9.0 & 5.4 \\
\hline 5 & 4.1 & 1.5 & 2.2 & 0.5 & 7.0 & 3.0 & 26.0 & n.d. & 29.1 & 8.4 & 13.0 & 2.9 & 3.4 & 9.2 & 4.6 \\
\hline 6 & 2.1 & 0.2 & 0.9 & 0.3 & 6.6 & 1.6 & 26.6 & n.d. & n.d. & 5.6 & 13.5 & 2.1 & 3.2 & 12.6 & 9.3 \\
\hline
\end{tabular}



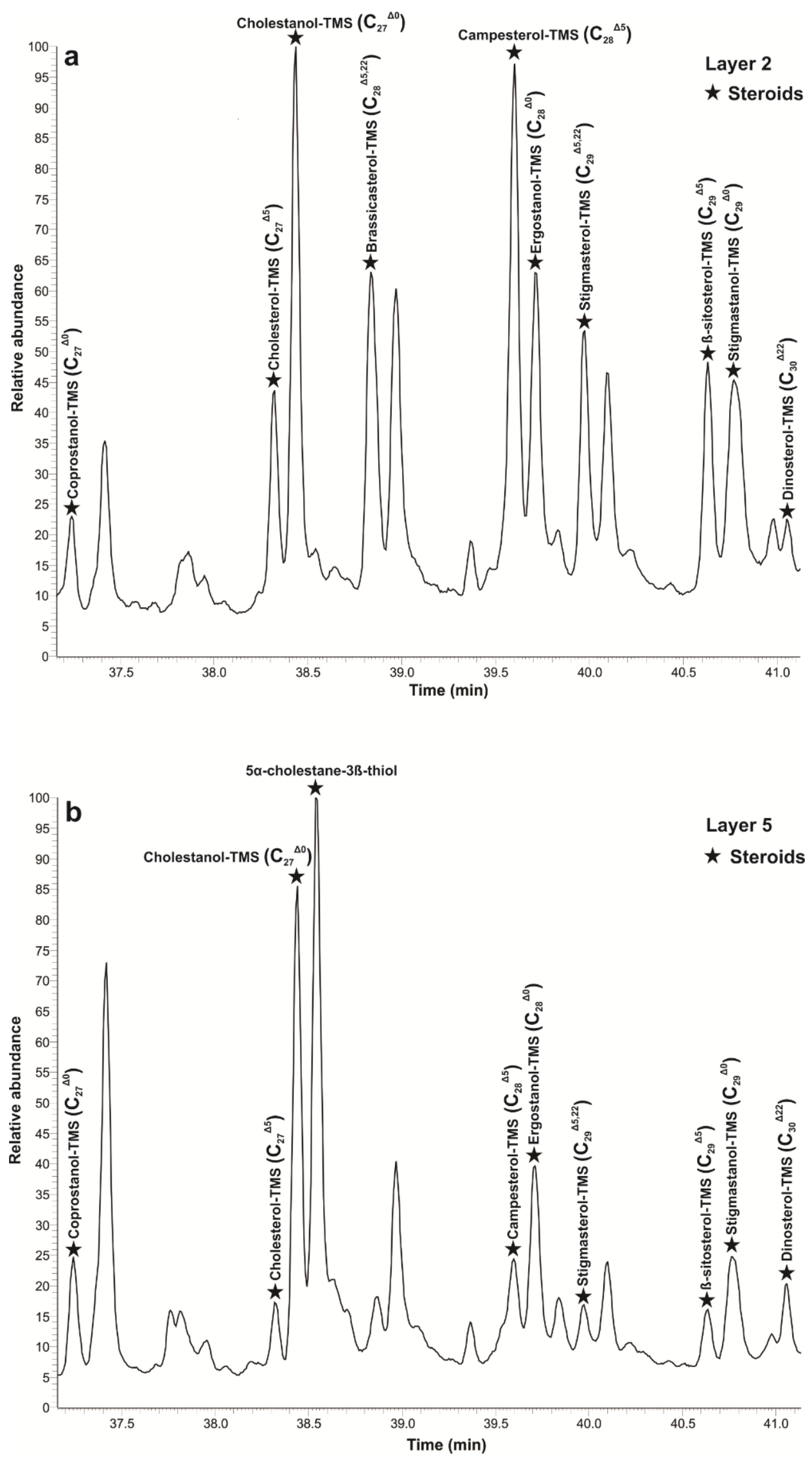

Figure 2.3 Partial GC-MS chromatograms (total ion current) showing sterol distributions (TMSderivatives) in (a) layer 2, and (b) layer 5 of the microbial mat studied. 


\subsubsection{Relative variations of steroids}

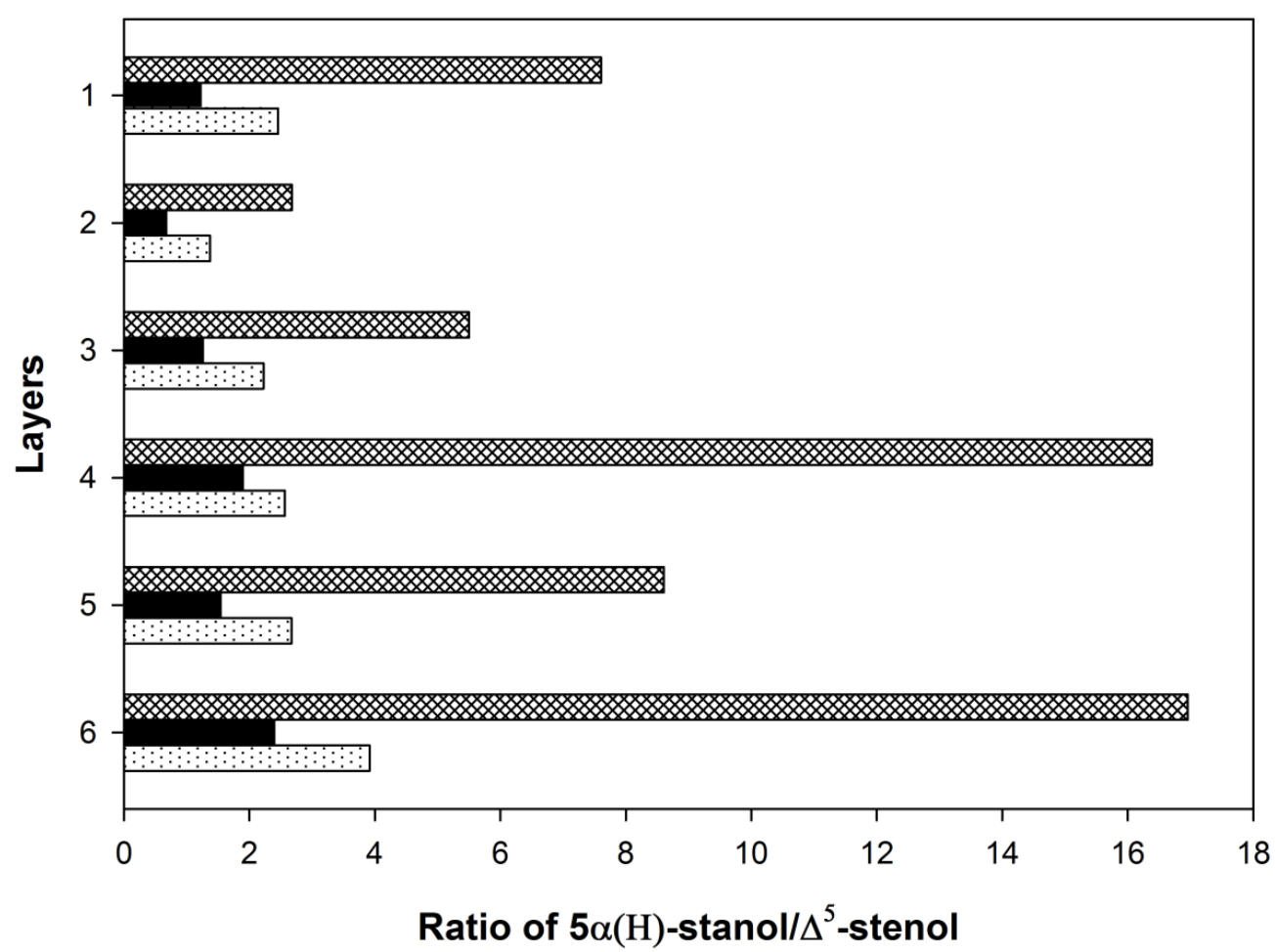

$\mathrm{C}_{27} 5 \alpha(\mathrm{H})$-stanol/ $\mathrm{C}_{27} \Delta^{5}$-stenol (cholestanol/cholesterol)

$\mathrm{C}_{28} 5 \alpha(\mathrm{H})$-stanol/ $\mathrm{C}_{28} \Delta^{5}$-stenol (ergostanol/campesterol)

$\therefore \because \mathrm{C}_{29} 5 \alpha(\mathrm{H})$-stanol/ $\mathrm{C}_{29} \Delta^{5}$-stenol (stigmastanol/ $\beta$-sitosterol)

Figure 2.4 Stanol/stenol ratios for the microbial mat layers.

The ratios of $5 \alpha$-stanols to their corresponding $\Delta 5$-stenols ( $\Delta 5$ : stenols with double bond located at C-5) showed a clear increase with depth (Figure 2.4). The highest stanol/stenol ratios were observed for layer 6, with 17.0, 2.4, and 3.9 for the C27-, C28-, and C29- pairs, respectively (Table 2.3 $)$. Likewise, sterene/( $\Delta 5$-stenol $+\Delta 5,22$-stenol) ratios (sterene/stenol) increased with depth (Figure 2.5). Here, C27- and C28- sterene/stenol ratios were highest in layer 5 (1.86 and 0.27, respectively), while the C29- compounds showed the highest ratio (0.11) in layer 3 (Table 2.3).

Table 2.3 Stanol/stenol and sterene/stenol ratios for the microbial mat layers.

\begin{tabular}{|c|c|c|c|c|c|c|}
\hline \multirow{2}{*}{ Layer } & \multicolumn{3}{|c|}{ stanol/stenol $\left(\Delta^{0} / \Delta^{5}\right)$} & \multicolumn{3}{c|}{ sterene/stenol (sterene/ $\left.\Delta^{5}+\Delta^{5,22}\right)$} \\
\cline { 2 - 7 } & $\mathrm{C}_{27}$ & $\mathrm{C}_{28}$ & $\mathrm{C}_{29}$ & $\mathrm{C}_{27}$ & $\mathrm{C}_{28}$ & $\mathrm{C}_{29}$ \\
\hline 1 & 7.6 & 1.2 & 2.5 & 0.63 & 0.07 & 0.06 \\
\hline 2 & 2.7 & 0.7 & 1.4 & 0.40 & 0.03 & 0.06 \\
\hline 3 & 5.5 & 1.3 & 2.2 & 0.60 & 0.08 & 0.11 \\
\hline 4 & 16.4 & 1.9 & 2.6 & 1.25 & 0.08 & 0.05 \\
\hline 5 & 8.6 & 1.6 & 2.7 & 1.86 & 0.27 & 0.08 \\
\hline 6 & 17.0 & 2.4 & 3.9 & 1.48 & 0.16 & 0.06 \\
\hline
\end{tabular}




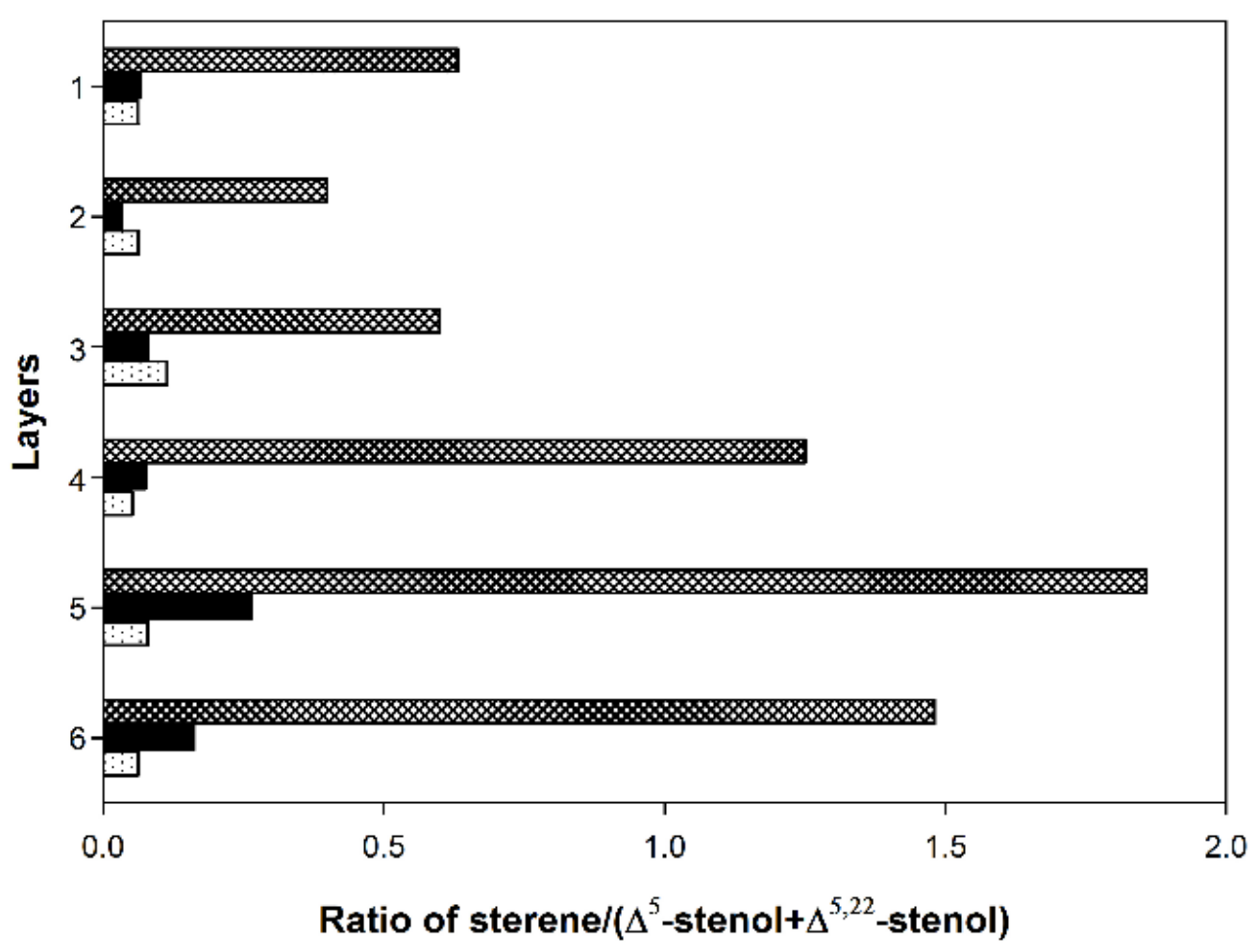

$\mathrm{C}_{27}$ sterene $/\left(\Lambda^{5}\right.$-stenol $+\Lambda^{5,22}$-stenol $)$
$\mathrm{C}_{28}$ sterene $/\left(\Delta^{5}\right.$-stenol $+\Delta^{5,22}$-stenol $)$
$\mathrm{C}_{29}$ sterene $/\left(\Delta^{5}\right.$-stenol+ $+\Delta^{5,22}$-stenol $)$

Figure 2.5 Sterene/stenol ratios for the microbial mat layers.

Figure 2.6 illustrates the relative abundance of the different steroid classes with respect to the total steroids in each mat layer (see also Table 2.3). The percentages of both sterenes and stanols increased with depth, whereas the relative contributions of stenols declined. However, no systematic decrease in the total amount of steroids with depth was observed. While the highest abundance of total steroids occurred in layer $2(125.6 \mu \mathrm{g} / \mathrm{g}$ dry mat), the second highest value appeared deep in the mat (layer 5: $110.5 \mu \mathrm{g} / \mathrm{g}$ dry mat), and the lowest value was found for layer $3(49.1 \mu \mathrm{g} / \mathrm{g}$ dry mat $)$. 


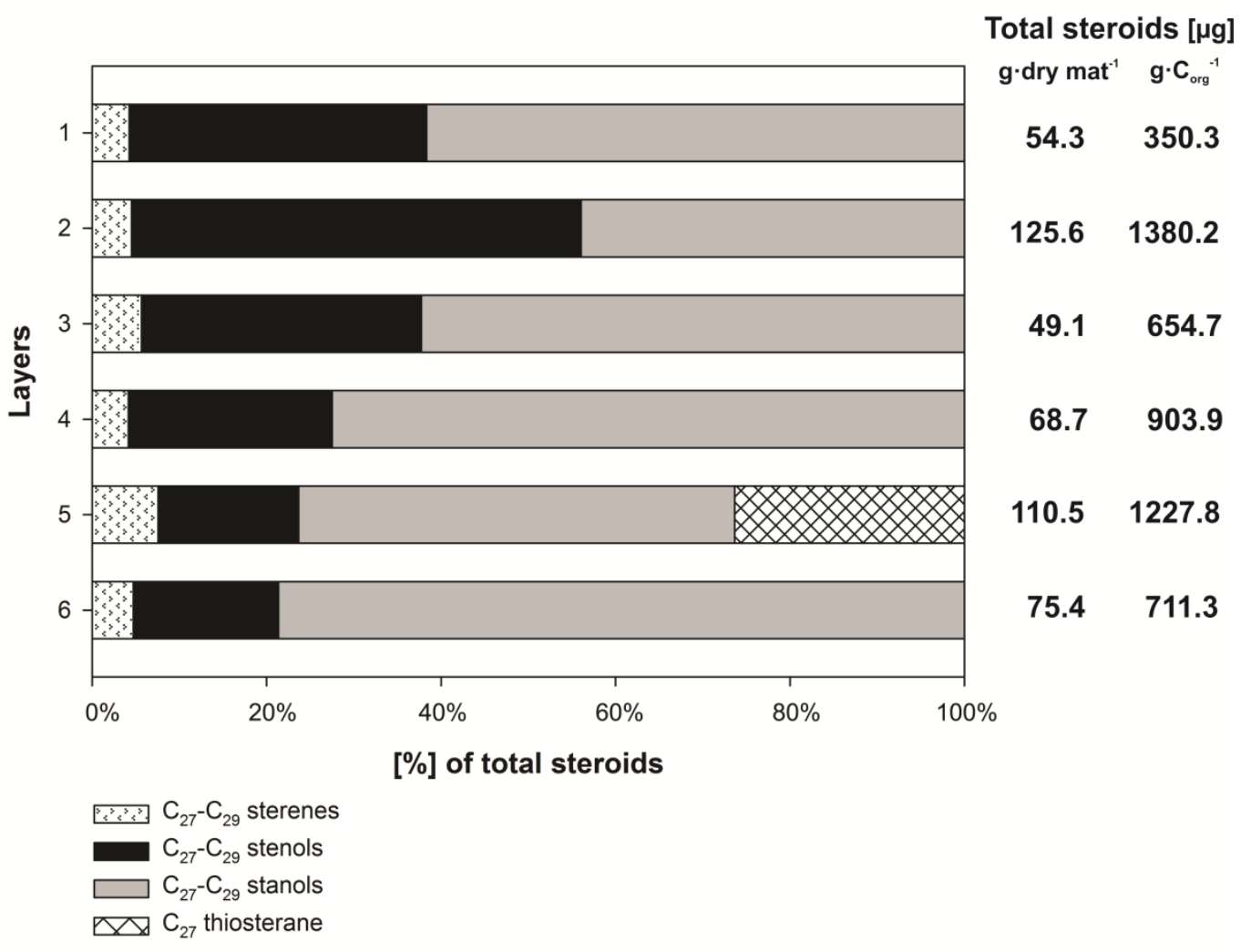

Figure 2.6 Proportions of different steroid classes in the microbial mat layers.

\subsubsection{Steroids vs. hopanoids and fatty acids}

Hopanoids and fatty acids (FAs) were observed in each mat layer. Compound distributions and concentrations (normalized to dry sample wt.) are detailed in Table A.1. The summed concentrations of the major GC-amenable hopanoids, FAs, and steroids (for comparison) are shown in Figure 2.7. Hopanoids increase in abundance with depth, while FAs and steroids show no obvious trend. FAs are several times more abundant than steroids, but the distributions of these compound classes are very similar (high amounts in layer 2, low amounts in layers 3 and 4). Largely the same distributions were observed when the compound concentrations were plotted against $\mathrm{C}_{\mathrm{org}}$, according to fairly constant organic carbon contents in all microbial mat layers ( $7-10 \%$ in layers $2-5)$. The only exception is layer 1, which shows the lowest abundances of all three lipid classes relative to $\mathrm{C}_{\mathrm{org}}$, which is notably increased $(15.5 \%)$. 


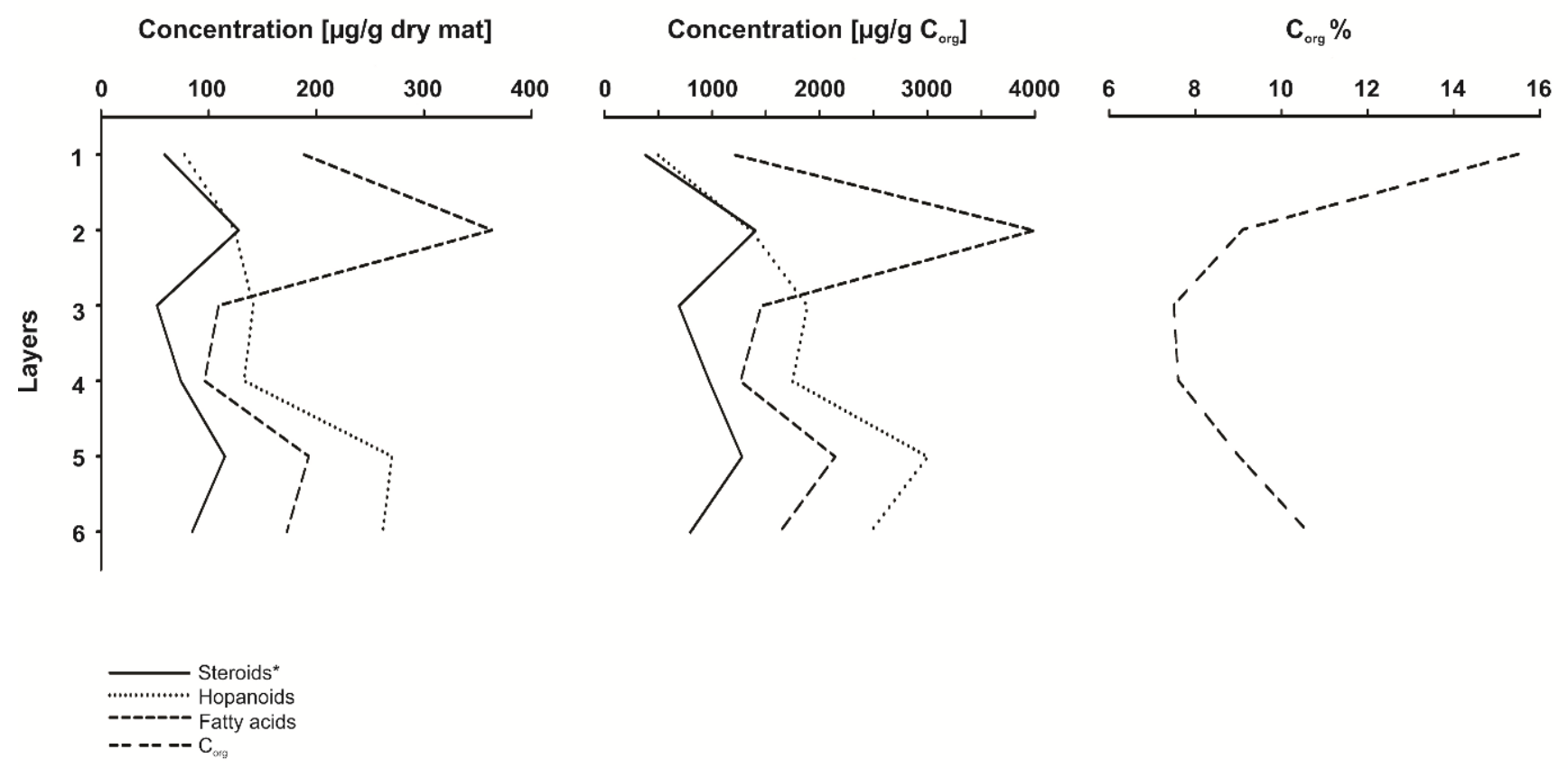

Figure 2.7 Abundances of steroids, hopanoids, fatty acids ( $\mu \mathrm{g} / \mathrm{g}$ dry mat; $\mu \mathrm{g} / \mathrm{g} \mathrm{C}_{\text {org }}$ ), and $\mathrm{C}_{\text {org }}$ (wt. \%) in the microbial mat layers.

\subsubsection{Pyrolysis}

In addition to the extractable lipid portion, the extraction residues of the microbial mat layers were analyzed using Py-GC-MS. Ion chromatograms representing steroids (i.e. including sterenes, steranes and sterols) and hopanoids are shown in Figure A.2. Pyrolysis yielded no detectable amounts of steroids from any of mat layers, whereas hopanoids were always present.

\subsection{Discussion}

\subsubsection{Sources and diagenetic pathways of steroids}

Sterol biomarkers have been broadly reported from modern and ancient environments, and it is commonly accepted that some of these compounds are diagnostic for major taxonomic groups of eukaryotes (Brocks and Summons, 2004; Peters, Walters and Moldowan, 2005; Volkman, 1986; Volkman, Kearney and Jeffrey, 1990; Volkman, 2003). Steroids have previously been reported in a number of microbial mats from Kiritimati (Bühring et al., 2009) and other meso- to hypersaline environments (Grimalt, de Wit, Teixidor and Albaigés, 1992; Scherf and Rullkötter, 2009; Słowakiewicz et al., 2016). The analyzed Kiritimati mat also contained a broad variety of $\mathrm{C}_{27}-\mathrm{C}_{30}$ steroids, reflecting mixed inputs mainly by animals $\left(\mathrm{C}_{27}\right)$, fungi $\left(\mathrm{C}_{28}\right)$, algae $\left(\mathrm{C}_{27}-\mathrm{C}_{29}\right)$ including dinoflagellates $\left(\mathrm{C}_{30}\right)$, and terrestrial plants $\left(\mathrm{C}_{29}\right)$. 59 
Concentrations of steroids in the mat studied are in the same order $\left(\sim 10^{2}-10^{3} \mu \mathrm{g} / \mathrm{g} \mathrm{C}_{\text {org }}\right)$ as those previously reported from Kiritimati Lake 2A (Bühring et al., 2009) and from solar salterns in southern Spain (Grimalt, De Wit, Teixidor and Albaigés, 1992), but are considerably higher as those observed in mats from Qatar and Abu Dhabi $\left(\sim 10^{1}-10^{2} \mu \mathrm{g} / \mathrm{g} \mathrm{C}_{\text {org }}\right.$; Scherf and Rullkötter, 2009; Słowakiewicz et al., 2016).

Eukaryotes generally rely on an oxygenated environment and are unlikely to thrive in deeper, anoxic mat layers. Rather, the steroids in the analyzed microbial mat derived from mat surface-dwelling or planktonic organisms. These compounds were probably introduced as stenols, and were then altered by diagenetic processes, resulting in the observed variety of steroids. For instance, the formation of $5 \alpha$-stanols through the reduction of $\Delta^{5}$-stenols (hydrogenation) is mainly a result of anaerobic microbial transformation (Rosenfeld and Hellman, 1971; Wakeham, 1989). Therefore, stanol/stenol ratios have often been used as an indicator for biological degradation under anoxic conditions, with high values reflecting low redox potentials (Gagosian et al., 1980; Gaskell and Eglinton, 1975; Nishimura, 1977; Wakeham, 1989). The presence of stanols was also reported from deeper layers of other microbial mats (Grimalt, de Wit, Teixidor and Albaigés, 1992; Bühring et al., 2009; Scherf and Rullkötter, 2009; Słowakiewicz et al., 2016). In the microbial mat studied, all stanol/stenol ratios showed enhanced values with depth (igure 2.4), and highest values were observed in the bottom mat layer. This is in good agreement with an increasing microbial conversion of stenols to stanols occurring under anaerobic conditions in deeper mat layers.

In addition to abundant $5 \alpha$-stanols, the $5 \beta$-stanols coprostanol and (minor) epi-coprostanol

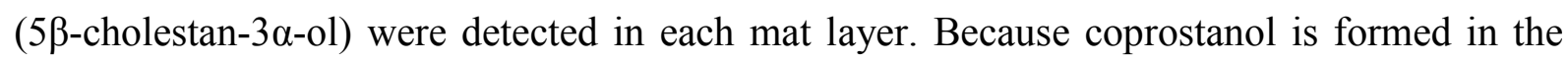
intestines of many mammals, including humans, it has been used as a biomarker for sewage contamination (Hatcher and McGillivary, 1979; Writer et al., 1995). The ratio of coprostanol/(coprostanol+cholestanol) has been used to distinguish an urban contaminant source, where values between 0.7 and 1 indicate sewage pollution, while ratios from 0.1 to 0.3 typically occur in uncontaminated sediments (Grimalt, Fernández, Bayona and Albaigés, 1990). In the microbial mat studied, ratios between 0.1 and 0.3 indicate that the sample has not received urban pollution. Coprostanol can thus be considered a diagenetic product of $\Delta^{5}$ stenols rather than a sewage contaminant, which is in agreement with the remote natural environment of Lake 22. $5 \beta$-stanols can be produced from $\Delta^{5}$-stenols via intermediate steroidal ketones, or by direct conversion in very reducing environments (Edmunds, Brassell and Eglinton, 1980; Robinson, Eglinton, Brassell and Cranwell, 1984). In the mat studied 
neither stanones nor stenones were above detection limit, suggesting that coprostanol was rapidly, and possibly directly, formed from its corresponding $\Delta^{5}$-stenol, cholesterol. This is in good agreement with observations made in deeper layers of a cyanobacterial mat from southern Spain (Grimalt, de Wit, Teixidor and Albaigés, 1992).

Sedimentary sterenes are diagenetic intermediates formed through microbiological reduction and dehydration of stenols (Dastillung and Albrecht, 1977). The occurrence of sterenes has also been reported from other microbial mats in meso- to hypersaline settings (Grimalt, de Wit, Teixidor and Albaigés, 1992; Bühring et al., 2009; Scherf and Rullkötter, 2009; Słowakiewicz et al., 2016). In the Kiritimati mat, the progressive transformation of sterols into sterenes with depth is well reflected by increasing sterene/stenol ratios for the $\mathrm{C}_{27^{-}}$ and, to a slightly lesser extent, for the $\mathrm{C}_{28^{-}}$pseudohomologues (Figure 2.5). Interestingly, this trend was not evident for the $\mathrm{C}_{29}$ - compounds, possibly reflecting that the original $\mathrm{C}_{29}$ stenols were not used by, or less accessible to, the respective microorganisms.

$5 \alpha$-cholestane-3 $\beta$-thiol was exclusively observed in layer 5 , where it comprised $26.3 \%$ of the summed steroids (igure 2.3b). Thiosteranes are not biosynthesized directly, but form as a result of diagenetic sulfur incorporation into the respective sterols via microbial processes or abiotic reactions in the presence of high amounts of sulfide (Hebting et al., 2006). The $C_{27}$ thiosterane potentially indicates fecal pollution (Louati et al., 2001), but as discussed above sewage contamination appears unlikely for the sampling site. The strong preference of the $\mathrm{C}_{27}$ thiosterane in a distinct mat layer and the virtual absence of $\mathrm{C}_{28^{-}}$and $\mathrm{C}_{29^{-}}$thiosteranes therefore suggest a sudden, monospecific input of organic matter with a high $\mathrm{C}_{27}$ sterol content. Possible sources include animal faeces or salinity-driven mass mortality of fish or crustaceans.

\subsubsection{Depth distributions of steroids vs. hopanoids and fatty acids (FAs)}

The mat contains high amounts of unspecific $\mathrm{C}_{16}$ and $\mathrm{C}_{18} \mathrm{FAs}$, but also abundant iso-/anteiso$\mathrm{C}_{15}$ and cyclopropyl- $\mathrm{C}_{19}$ FAs that clearly have a bacterial origin (Kates, 1964; Anhalt and Fenselau, 1975). The relative depth distribution of FAs and steroids is similar and shows no clear trend through the mat (Figure 2.7), as also reflected by fairly constant steroids/FAs ratios (Table A.2). This suggests that both compound classes have a similar taphonomic fate in the analyzed hypersalinar microbial mat from Kiritimati. 
Unlike the steroids and FAs, the major GC-amenable hopanoids (bishomohopanoic acid, bishomohopanol and trishomohopanol; Table A.1) increased in abundance with depth (Figure 2.7). This increase in GC-amenable hopanoids results in decreasing steroid/hopanoid ratios (Table A.2). However, it should be considered that the compounds observed are no primary biosynthates but represent the diagenetic products of bacteriohopanepolyols (BHPs; Rohmer, Bouvier-Nave and Ourisson, 1984). It is therefore likely that a major portion of the observed GC-amenable hopanoids has been formed within the mat through the progressive defunctionalization of BHPs. Another part of BHPs (or their alteration products) obviously becomes incorporated into macromolecular organic matter, as indicated by the release of hopanoid moieties upon pyrolysis of the extraction residues (see chapter. 2.3.6, Figure A.2).

A further potential source of hopanoids is new production of BHPs at greater mat depths, as it has e.g. been observed for a mat from another lake on Kiritimati (Blumenberg et al., 2013). It can be expected, however, that such an additional input would be accompanied by a concurrent increase in bacterial FAs. This has not been observed in the mat studied (Table A.2), which may point against major additional contributions of bacterial lipids in deeper mat layers.

\subsubsection{Preservation of eukaryotic steroids - taphonomically biased?}

Taken together, the series of microbial/diagenetic transformations of biological sterols in the microbial mat studied appears to be fully analogous to the known sedimentary reaction series eventually yielding saturated steranes (stenols $=>$ stanols $=>$ sterenes $=>$ steranes). As the summed steroids (i.e. original stenols plus their transformation products) do not decrease in abundance with depth, it appears that these processes are not accompanied by a major destruction of steroidal carbon skeletons. Rather, heterotrophic microbial activity in the reducing environment of the mat led to progressive transformation (hydrogenation and dehydration) of the original sterols. The presence of a thiosterane in one of the samples also points to the possibility of an abiotic formation, and preservation, of sulfurized steranes in deeper mat layers.

The systematic decrease of $\Delta^{5}$-stenols vs. their diagenetic products also implies that no significant, if any, biological production of steroids occurred within the deeper mat layers that may have biased the distributions observed. Most likely, $\Delta^{5}$-stenols had successively been introduced at the mat surface, and have been buried and transformed in deeper, anoxic layers during further growth of the mat. We do not know, however, about possible variations in the 
original inputs of these primary sterols. Such variation may have existed as e.g. revealed by the observation that a compound of a clearly algal origin, dinosterol, was actually more abundant in the lowermost mat layer than at the surface (Table 2.2). Nevertheless, the consistent presence of steroids in ample amounts throughout the profile does not support a preferential degradation of these compounds in the microbial mat studied.

Pyrolysis of the extraction residues revealed that steroids were not introduced into insoluble OM (proto-kerogen), while hopanoids were present in all pyrolysates (Figure A.2). This can plausibly be explained by the degree of functionalization in the biological precursors. BHPs are highly functionalized at their side chain (e.g. four hydroxyl-groups in bacteriohopanetetrol). It has been shown that hopanoids become rapidly ( $\leq 350 \mathrm{yrs})$ incorporated into macromolecular OM via cross-linking of reactive sites (Farrimond et al., 2003). Steroids, in contrast, typically exhibit only few reactive sites (e.g. one hydroxyl-group and one double bond in cholesterol). This may explain the exclusive presence of steroids in the extractable (lipid) portion of the mat studied, and the lack of any significant sequestration of steroids into macromolecular OM on a $10^{3}$ yrs timescale.

Summarizing, our data clearly show conspicuously high concentrations of eukaryotic steranes even after the pronounced microbial alteration within the mat. Hence, the steroids are not destroyed while transported through the mat studied, which, at first glance, argues against the "mat-seal effect" in this particular case. On the other hand, the results reveal a relative increase of GC-amenable hopanoids over steroids with depth. These compounds are most likely sourced from defunctionalized BHPs whose concentrations may even increase in deeper mat layers, as it has been shown for a different mat on Kiritimati (Blumenberg et al. 2013). Consequently, the steroid/hopanoid ratios at the bottom of a microbial mat will tend to be lower than in the primary signal. On longer terms, the preservation of hopanoids may additionally be promoted by a more effective incorporation into the early (proto-) kerogen, as indicated by the pyrolysis data. 


\subsection{Conclusion}

In a hypersaline microbial mat from Kiritimati, progressive alteration of primary sterols occurred with mat depth. This resulted in relative increases in stanols and sterenes vs. $\Delta^{5}$ stenols, as well as the presence of thiosteranes in certain mat layers. These alterations can partly be assigned to microbial transformation processes but are probably also due to chemical reactions promoted by the reducing environment of the deeper mat layers. Steroids were nevertheless abundant in all mat layers and their summed concentrations did not show any systematic decrease with depth. Obviously, the microbial mat studied does not form an effective barrier against eukaryote-derived steroids over a time scale of c. $10^{3}$ years. On the other hand, decreasing steroid/hopanoid ratios with depth indicate a progressive "dilution" of the eukaryotic signal by lipids of heterotrophic bacteria. It can also be anticipated that the observed lack of protective sequestration into (proto-) kerogen would lead to a preservational bias at the expense of steroids during later stages of burial. This underlines that steroid preservation in microbial mats may not be exclusively controlled by heterotrophic degradation, but rather depends on a complex interplay of taphonomic processes.

\section{Acknowledgements}

We thank Prof. Dr. Gernot Arp and Dr. Martin Blumenberg for providing helpful information and comments. Dr. Andreas Reimer is acknowledged for hydrochemical measurements. We also thank Wolfgang Dröse, Birgit Röring, and Dorothea Hause-Reitner for laboratory assistance. We are grateful to three anonymous reviewers and the editors for their constructive comments that helped to improve the manuscript. The German Research Foundation (DFG, project Re 665/18-2 and Research Unit 571 "Geobiology of Organo- and Biofilms”) is kindly acknowledged for financial support. This is publication number 4 of the Early Life Working Group (Department of Geobiology, University of Göttingen; Göttingen Academy of Sciences and Humanities). 


\section{References}

Anbar, A. D. and Knoll, A. H. (2002). Proterozoic ocean chemistry and evolution: a bioinorganic bridge? Science, 297, 1137-1142.

Anhalt, J. P. and Fenselau, C. (1975). Identification of bacteria using mass spectrometry. Analytical Chemistry, 47, 219-225.

Arp, G., Helms, G., Karlinska, K., Schumann, G., Reimer, A., Reitner, J. and Trichet, J. (2012). Photosynthesis versus exopolymer degradation in the formation of microbialites on the atoll of Kiritimati, Republic of Kiribati, Central Pacific. Geomicrobiology Journal, 29, $29-65$.

Blumenberg, M., Thiel, V., Riegel, W., Kah, L. C. and Reitner, J. (2012) Black shale formation by microbial mats, Late Mesoproterozoic (1.1 Ga) Taoudeni Basin, Mauritania. Precambrian Research 196-197, 113-127.

Blumenberg, M., Arp, G., Reitner, J., Schneider, D., Daniel, R. and Thiel, V. (2013). Bacteriohopanepolyols in a stratified cyanobacterial mat from Kiritimati (Christmas Island, Kiribati). Organic Geochemistry, 55, 55-62.

Blumenberg, M., Thiel, V. and Reitner, J. (2015). Organic matter preservation in the carbonate matrix of a recent microbial mat - Is there a 'mat seal effect'? Organic Geochemistry, 87, 25-34.

Bottjer, D. J., Hagadorn, J. W. and Dornbos, S. Q. (2000). The Cambrian Substrate Revolution. Geological Society of America (GSA Today), 10, 2-8.

Brocks, J. J. and Summons, R. E. (2004). Sedimentary Hydrocarbons, Biomarkers for Early Life. In R. W. Carlson (Eds.), Treatise on Geochemistry (63-115). Oxford: Elsevier.

Bühring, S. I., Smittenberg, R. H., Sachse, D., Lipp, J. S., Golubic, S., Sachs, J. P., Hinrichs K. U., Summons, R. E. (2009). A hypersaline microbial mat from the Pacific Atoll Kiritimati: insights into composition and carbon fixation using biomarker analyses and a ${ }^{13} \mathrm{C}$-labeling approach. Geobiology, 7, 308-323.

Canfield, D. E., Sørensen, K. B. and Oren, A. (2004). Biogeochemistry of a gypsumencrusted microbial ecosystem. Geobiology, 2, 133-150.

Canfield, D. E. and Des Marais, D. J. (1993). Biogeochemical cycles of carbon, sulfur, and free oxygen in a microbial mat. Geochimica et Cosmochimica Acta, 57, 3971-3984.

Dastillung, M. and Albrecht, P. (1977). $\Delta^{2}$-Sterenes as diagenetic intermediates in sediments. Nature, 269, 678-679.

Edmunds, K., Brassell, S. and Eglinton, G. (1980). The short-term diagenetic fate of $5 \alpha-$ cholestan-3 $\beta$-ol: in situ radiolabelled incubations in algal mats. Physics and Chemistry of the Earth, 12, 427-434.

Farrimond, P., Love, G. D., Bishop, A. N., Innes, H. E., Watson, D. F. and Snape, C. E. (2003). Evidence for the rapid incorporation of hopanoids into kerogen. Geochimica et Cosmochimica Acta, 67, 1383-1394. 
Gagosian, R. B., Smith, S. O., Lee, C., Farrington, J. W. and Frew, N. M. (1980). Steroid transformations in recent marine sediments. Physics and Chemistry of the Earth, 12, 407419.

Gaskell, S. J. and Eglinton, G. (1975). Rapid hydrogenation of sterols in a contemporary lacustrine sediment. Nature, 254, 209-211.

Grimalt, J. O., de Wit, R., Teixidor, P. and Albaigés, J. (1992). Lipid biogeochemistry of Phormidium and Microcoleus mats. Organic Geochemistry, 19, 509-530.

Grimalt, J. O., Fernández, P., Bayona, J. M. and Albaigés, J. (1990). Assessment of fecal sterols and ketones as indicators of urban sewage inputs to coastal waters. Environmental Science and Technology, 24, 357-363.

Grotzinger, J. P. and Knoll, A. H. (1999). Stromatolites in Precambrian carbonates: evolutionary mileposts or environmental dipsticks? Annual review of earth and planetary sciences, 27, 313-358.

Hatcher, P. G. and McGillivary, P. A. (1979). Sewage contamination in the New York Bight. Coprostanol as an indicator. Environmental Science and Technology, 13, 1225-1229.

Hebting, Y., Schaeffer, P., Behrens, A., Adam, P., Schmitt, G., Schneckenburger, P., Bernasconi, S. M. and Albrecht, P. (2006). Biomarker evidence for a major preservation pathway of sedimentary organic carbon. Science, 312, 1627-1631.

Hoehler, T. M., Bebout, B. M. and Des Marais, D. J. (2001). The role of microbial mats in the production of reduced gases on the early Earth. Nature, 412, 324-327.

Ionescu, D., Spitzer, S., Reimer, A., Schneider, D., Daniel, R., Reitner, J., De Beer, D. and Arp, G. (2015). Calcium dynamics in microbialite-forming exopolymer-rich mats on the atoll of Kiritimati, Republic of Kiribati, Central Pacific. Geobiology, 13, 170-180.

Kates, M. (1964). Bacterial Lipids** Issued as N.R.C. No. 8043. In Advances in Lipid Research. Bacterial Lipids (Vol. 2, pp.17-90). Elsevier

Knoll, A. H., Summons, R. E., Waldbauer, J. R. and Zumberge, J. E. (2007). The Geological Succession of Primary Producers in the Oceans. In P. G. Falkowski and A. H. Knoll (Eds.), Evolution of Primary Producers in the Sea (133-163). Oxford: Elsevier.

Louati, A., Elleuch, B., Sandra, P., David, F., Saliot, A., Dagaut, J. and Oudot, J. (2001). Identification of thiosteranes in contaminated marine sediments from the Mediterranean Sea by capillary GC-MS and capillary GC-AED. Journal of Microcolumn Separations, 13, 90-95.

Nishimura, M. (1977). Origin of stanols in young lacustrine sediments. Nature, 270, 711-712.

Pawlowska, M. M., Butterfield, N. J. and Brocks, J. J. (2013). Lipid taphonomy in the Proterozoic and the effect of microbial mats on biomarker preservation. Geology, 41, 103106.

Peters, K. E., Walters, C. C. and Moldowan, J. M. (2005). The Biomarker Guide: Part ПBiomarkers and Isotopes in Petroleum Exploration and Earth History. Cambridge University Press, New York. 
Riding, R. (2011). The Nature of Stromatolites: 3,500 Million Years of History and a Century of Research. In J. Reitner, N.-V. Quéric and G. Arp (Eds.), Lecture Notes in Earth Sciences 131. Advances in Stromatolite Geobiology (29-74). Springer Verlag, Berlin Heidelberg.

Robinson, N., Eglinton, G., Brassell, S. C. and Cranwell, P. A. (1984). Dinoflagellate origin for sedimentary $4 \alpha$-methylsteroids and $5 \alpha(\mathrm{H})$-stanols. Nature, 308, 439-442.

Rohmer, M., Bouvier-Nave, P. and Ourisson, G. (1984). Distribution of hopanoid triterpenes in prokaryotes. Journal of General Microbiology, 130, 1137-1150.

Rosenfeld, R. S. and Hellman, L. (1971). Reduction and esterification of cholesterol and sitosterol by homogenates of feces. Journal of Lipid Research, 12, 192-197.

Saenger, C., Miller, M., Smittenberg, R. H. and Sachs, J. P. (2006). A physico-chemical survey of inland lakes and saline ponds: Christmas Island (Kiritimati) and Washington (Teraina) Islands, Republic of Kiribati. Saline systems, 2(8), 1-15.

Scherf, A.-K. and Rullkötter, J. (2009). Biogeochemistry of high salinity microbial mats Part 1: Lipid composition of microbial mats across intertidal flats of Abu Dhabi, United Arab Emirates. Organic Geochemistry, 40, 1018-1028.

Schneider, D., Arp, G., Reimer, A., Reitner, J. and Daniel, R. (2013). Phylogenetic Analysis of a Microbialite-Forming Microbial Mat from a Hypersaline Lake of the Kiritimati Atoll, Central Pacific. PLoS One, 8, e66662.

Seilacher, A. (1999). Biomat-Related Lifestyles in the Precambrian. PALAIOS, 14, 86-93.

Seilacher, A. and Pflüger, F. (1994). From biomats to benthic agriculture: A biohistoric revolution. In W. E. Krumbein, D. M. Paterson and L. J. Stal (Eds.), Biostablization of Sediments (97-105). Bibliotheks- und Informationssystem der Carl von Ossietzky Universität Oldenburg, (BIS)-Verlag, Oldenburg.

Słowakiewicz, M., Whitaker, F., Thomas, L., Tucker, M. E., Zheng, Y., Gedl, P. and Pancost, R. D. (2016). Biogeochemistry of intertidal microbial mats from Qatar: New insights from organic matter characterisation. Organic Geochemistry, 102, 14-29.

Summons, R. E., Powell, T. G. and Boreham, C. J. (1988). Petroleum geology and geochemistry of the middle Proterozoic McArthur Basin, Northern Australia: III. Composition of extractable hydrocarbons. Geochimica et Cosmochimica Acta, 52, 17471763

Trichet, J., Défarge, C., Tribble, J., Tribble, G. and Sansone, F. (2001). Christmas Island lagoonal lakes, models for the deposition of carbonate-evaporite-organic laminated sediments. Sedimentary Geology, 140, 177-189.

Valencia, M. (1977). Christmas Island (Pacific Ocean): Reconnaissance geologic observations. Atoll Research Bulletin. (197), 1-19.

Van den Ende, F. P. and Van Gemerden, H. (1994). Relationships between functional groups of organisms in microbial mats. In L. J. Stal and P. Caumette (Eds.), Microbial Mats (339352). Berlin, Heidelberg: Springer. 
Van Gemerden, H. (1993). Microbial mats: A joint venture. Marine Geology, 113, 3-25.

Volkman, J. K. (2003). Sterols in microorganisms. Applied Microbiology and Biotechnology, $60,495-506$.

Volkman, J. K., Kearney, P. and Jeffrey, S. W. (1990). A new source of 4-methyl sterols and $5 \alpha(\mathrm{H})$-stanols in sediments: prymnesiophyte microalgae of the genus Pavlova. Organic Geochemistry, 15, 489-497.

Volkman, J. K. (1986). A review of sterol markers for marine and terrigenous organic matter. Organic Geochemistry, 9, 83-99.

Wakeham, S. G. (1989). Reduction of stenols to stanols in particulate matter at oxic-anoxic boundaries in sea water. Nature, 342, 787-790.

Walter, M. R. (1976). Stromatolites. Developments in Sedimentology: Vol. 20. Amsterdam; New York: Elsevier.

Writer, J. H., Leenheer, J. A., Barber, L. B., Amy, G. L. and Chapra, S. C. (1995). Sewage contamination in the upper Mississippi River as measured by the fecal sterol, coprostanol. Water Research, 29, 1427-143. 


\title{
-Chapter 3-
}

\section{Sterol preservation in hypersaline microbial mats}

(published in Biogeoscience Discussion)

Yan Shen, Volker Thiel, Pablo Suarez-Gonzalez, Sebastiaan W. Rampen, Joachim Reitner

\begin{abstract}
Microbial mats are self-sustaining benthic ecosystems composed of highly diverse microbial communities. It has been proposed that microbial mats were widespread in Proterozoic marine environments, prior to the emergence of bioturbating organisms at the PrecambrianCambrian transition. One characteristic feature of Precambrian biomarker records is that steranes are typically absent or occur in very low concentrations. This has been explained by low eukaryotic source inputs, or degradation of primary produced sterols in benthic microbial mats ("mat-seal effect"). To better understand the preservational pathways of sterols in microbial mats we analysed freely extractable and carbonate-bound sterols as well as decalcified extraction residues in different layers of a recent calcifying mat ( $\sim 1500$ years) from the hypersaline Lake 2 on the island of Kiritimati, Central Pacific. A variety of $\mathrm{C}_{27}-\mathrm{C}_{29}$ sterols and distinctive $\mathrm{C}_{31} 4 \alpha$-methylsterols ( $4 \alpha$-methylgorgosterol and $4 \alpha$-methylgorgostanol, biomarkers for dinoflagellates) were detected in both lipid pools. These sterols most likely originated from organisms living in the water column and the upper mat layers. This autochthonous biomass experienced progressive microbial transformation and degradation in the microbial mat, as reflected by a significant drop in total sterols concentrations, up to $98 \%$, in the deeper layers, and a concomitant decrease in total organic carbon. Carbonate-bound sterols were generally low in abundance, suggesting that incorporation into the mineral matrix does not play a major role for the preservation of eukaryotic sterols in this mat. Likewise, pyrolysis revealed that steroids (i.e., including sterenes, steranes and sterols), in contrast to hopanoids, were not sequestered into insoluble organic matter which may give rise to a further bias in the preservation of steroids vs. hopanoids, particularly in the later stages of burial. While these findings argue for a strong 'mat-seal effect' in the mat studied, they markedly differ from recent findings made for another microbial mat growing in the near-by
\end{abstract}


hypersaline Lake 22 on the same island, where sterols showed no systematic decrease with depth. The observed discrepancies in the taphonomic pathways of sterols in microbial mats from Kiritimati may be linked to multiple biotic and abiotic factors including salinity and periods of subaerial exposure, implying that caution has to be exercised in the interpretation of sterols distributions in modern and ancient microbial mat settings.

Keywords: freely-extractable lipids, carbonate-bound lipids, eukaryotic steroids, mat-seal effect, pyrolysis

\subsection{Introduction}

Sterols, biological precursors of steroids, are commonly used as biological markers for specific classes of organisms (Atwood et al., 2014; Brocks and Summons, 2004; Rampen et al., 2009; Volkman, 1986; Volkman, 2005). Sterols have been found in many different types of depositional environments such as soils (van Bergen et al., 1997; Birk et al., 2012; Otto and Simpson, 2005), recent lacustrine and marine sediments (Brassell and Eglinton, 1983; Gaskell and Eglinton, 1976; Robinson et al., 1984; Volkman, 1986), as well as microbial mats from meso- to hypersaline conditions (Grimalt et al., 1992; Scherf and Rullkötter, 2009). Further, the hydrocarbon skeleton of sterols is relatively stable, and thus significant amounts can be preserved in the geological record (Brocks et al., 2017; Mattern et al., 1970).

Microbial mats are vertically laminated organo-sedimentary structures, which are primarily self-sustaining ecosystems (Des Marais, 2003), ranging in thickness from millimeters to decimeters. The mineralized fossil product of microbial mats are microbialites, which have a long geological history of over 3 billion years, indicating that microbial mats probably represented the earliest complex ecosystems on Earth (Reitner and Thiel, 2011). Microbial mats typically consist of many different functional groups of microorganisms which control the organic matter $(\mathrm{OM})$ turnover in the microbial mat. Major groups include cyanobacteria, colorless sulfur bacteria, purple sulfur bacteria and sulfate-reducing bacteria, but also eukaryotic organisms (Schneider et al., 2013; van Gemerden, 1993). A large proportion of the OM consists of extracellular polymeric substances (EPS), secreted by the microorganisms, which are crucial for the support and the development of the microbial mat (Wingender et al., 1999; Decho, 2011; Reitner and Thiel, 2011). EPS are rich in acidic groups that bind cations such as $\mathrm{Ca}^{2+}$, thereby inducing a strong inhibitory effect on the precipitation of common minerals formed within microbial mats, such as $\mathrm{CaCO}_{3}$ (Arp et al., 1999; Dupraz et al., 2009; 
Ionescu et al., 2015). Consequently, carbonate precipitation often occurs in deeper and older mat layers in which decomposing EPS gradually releases previously-bound $\mathrm{Ca}^{2+}$, thus facilitating carbonate supersaturation (Arp et al., 1999; Dupraz et al., 2009; Ionescu et al., 2015). Previous studies indicate that early sequestration into a mineral matrix may promote the preservation of organic compounds (Summons et al., 2013; Smrzka et al., 2017; Thiel et al., 1999). Hence, microbial mats possibly provide an enhanced chance for OM to survive in the geosphere if carbonate or other mineral precipitation occurs therein.

In the Proterozoic, microbial mats have been proposed to be a predominant life form in marine environments, in contrast to the Phanerozoic that is characterized by prosperity of biota (including fauna and flora) and a low abundance of benthic microbial mats (Grotzinger and Knoll, 1999; Riding, 2011; Walter, 1976). One of the characteristic features of the Precambrian biomarker records is that eukaryotic steranes are typically absent or occur in very low concentrations. This may be explained by a limited ecological distribution of eukaryotic algae and thus minor contributions of sterols to sedimentary OM (Anbar and Knoll, 2002; Blumenberg et al., 2012; Brocks et al., 2017; Knoll et al., 2007), and/or by a thermal degradation of sterols during catagenesis (e.g. in the 1640 Ma Barney Creek Formation and $1430 \mathrm{Ma}$ Velkerri Formation, Northern Australia, Dutkiewicz et al., 2003; Summons et al., 1988). An alternative explanation would be that eukaryotic lipids have been subject to a preservation bias due to the ubiquity of benthic microbial mats. It has been hypothesized that these mats would have formed a significant mechanical and chemical barrier against the preservation of eukaryotic lipids sourced from water column and upper mat layers, a phenomenon termed as "mat-seal effect" (Pawlowska et al., 2013). Selective preservation induced by the mat-seal effect would also impart a bias in favour of lipids derived from heterotrophic microorganisms living in the deeper mat layers, and cause a suppression of the primary ecological signal. This is different from the situation in the Phanerozoic, where OM from planktonic primary producers (including algae and bacteria) is more rapidly transferred to the sediment through sinking aggregates (such as crustacean faecal pellets), and without being reworked in benthic microbial mats (Close et al., 2011; Fowler and Knauer, 1986; Logan et al., 1995).

The Kiritimati atoll (Kiribati Republic, Central Pacific, Figure 3.1) is an ideal study site for investigating the taphonomy of sterols in microbial mats. The island is covered by c. 500 brackish to hypersaline lakes, most of which are populated by thick and highly developed benthic mats that are clearly laminated and show ongoing mineral precipitation, i.e. 
microbialite formation (Arp et al., 2012; Trichet et al., 2001; Valencia, 1977). Therefore, Kiritimati enables studies on the behaviour of sterols within various types of microbial mats thriving under different environmental conditions and showing different degrees of mineralization.
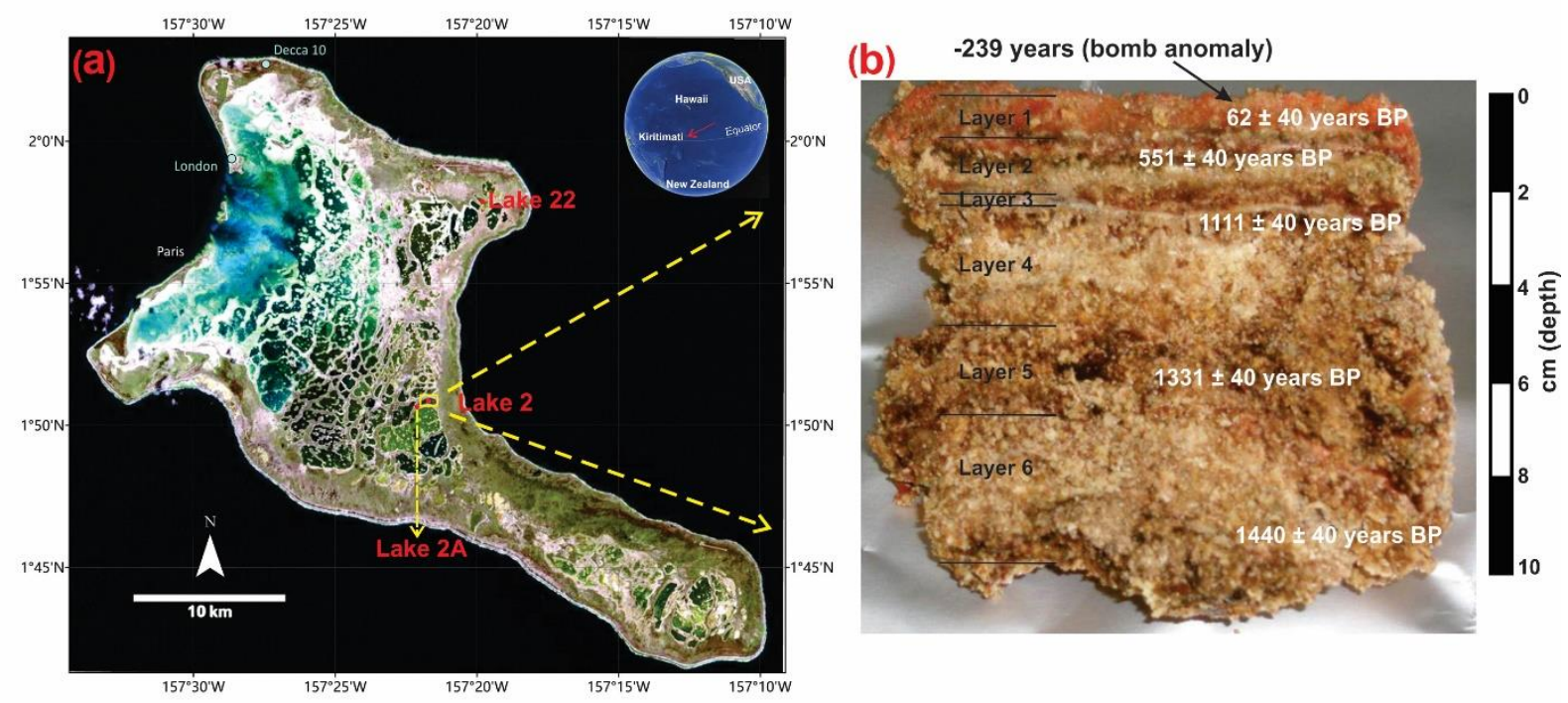

Figure 3.1 (a) Location of Kiritimati atoll in the Pacific Ocean and its satellite image showing reticulate distribution pattern of the lakes (red dots: Lake 2 studied in this work; Lake 2A and 22 previously studied by Bühring et al., 2009 and Shen et al., 2018a); (b) the microbial mat sample from Lake 2 studied in this work (14C data from Blumenberg et al., 2015).

A recent study conducted on a microbial mat from Lake 22 on Kiritimati demonstrated that a range of sterols were abundantly present in all parts of that mat. The lack of any systematic decrease with depth suggested that the sterols in that particular mat had not been impacted by a major mat-seal effect (Shen et al., 2018a). On the other hand, an earlier study on insoluble OM obtained from a microbial mat from a different lake of the same island (Lake 2, located about $10 \mathrm{~km}$ south of Lake 22) reported an increasing trend of hopane/sterane ratios with depth (Blumenberg et al., 2015). In conjunction with other findings, this was considered indicative of a "suppression of biosignatures derived from the upper mat layers" and thus, a mat-seal effect (Blumenberg et al., 2015). Since that work had a different focus and did not report detailed sterol data, it is not directly comparable with the results on the Lake 22 mat reported by Shen et al. (2018a). Therefore we revisited the microbial mat from Lake 2 and performed a detailed analysis of sterol compounds, investigating both freely extractable as well as carbonate-bound lipid fractions, and also decalcified extraction residues. Our study was aimed at further examining general trends in the preservation of sterols in hypersaline microbial mat systems by comparing the results from different settings within the same geological and geographical context (i.e. Lakes 2 and 22). 


\subsection{Materials and methods}

\subsubsection{Location and samples}

The atoll of Kiritimati (Republic of Kiribati) is located in the central part of the Pacific Ocean, close to the Equator (Figure 3.1). Its surface displays a complex reticular pattern encompassing c. 500 lakes with salinities that range from brackish to hypersaline. Most of the lakes harbour thick microbial mats that show ongoing mineralization processes (Figures 3.1, 3.2) and generally occur on top of older, more developed microbialites (i.e. already fossilized microbial mats; Arp et al., 2012; Ionescu et al., 2015; Trichet et al., 2001; Valencia, 1977). Vegetation around the lake areas comprises the mangrove Rhizophoramucronata, the parasitic climber Cassytha filiformis, the grass Lepturus repens, and the ironwood Pemphis acidula (Figure 3.2e; Saenger et al., 2006). The climate of Kiritimati is broadly controlled by the El Niño-Southern Oscillation (ENSO) atmospheric phenomenon. During El Niño wet events, heavy rains occur, decreasing lake salinities; whereas reduced precipitation during La Niña dry events triggers higher evaporation and increasing lake salinities (Arp et al., 2012; Saenger et al., 2006; Trichet et al., 2001). Materials studied in this work were sampled from Lake 2 (Figure 3.1), whose salinity was $97 \%$ in 2002 and $125 \%$ in 2011 (own data, unpublished). This high and variable salinity causes low metazoan diversity within Lake 2. Faunal elements include abundant Tilapia fish (Figure 3.2d) and Artemia brine shrimp as well as few land crabs, and unicellular miliolid foraminifera (Saenger et al., 2006; Shen et al., 2018a). Events of mass mortality of fish have been observed in some of the lakes (Figure 3.2d), which may be linked to extreme hypersaline conditions probably due to heavy evaporation during $\mathrm{La}$ Niña dry periods. More detailed information about the environmental setting of Kiritimati can be found elsewhere (Arp et al., 2012; Saenger et al., 2006; Shen et al., 2018a; Trichet et al., 2001).

In this work, a microbial mat from the hypersaline Lake 2, previously studied by Blumenberg et al. (2015), was analysed for sterols (Figure 3.1). This mat is $10 \mathrm{~cm}$ thick and was sampled from the centre of the lake (water depth c. $4 \mathrm{~m}$ ) during a field campaign in March 2011 (Figures 3.1, 3.2). Samples were stored at $-20^{\circ} \mathrm{C}$ until laboratory preparation. Based on the macroscopic appearance, Blumenberg et al. (2015) divided the mat in five layers, the topmost layer corresponding to the photosynthetically active mat, and layers 2-5 representing ancient mat generations being degraded by recent anaerobic microorganisms (Figures 3.1, 3.2). For this study, we used the same layer division as Blumenberg et al. (2015). However, a thin but distinctive mineral crust occurring just below layer 2 (Figure 
3.2c) has not been analysed in the previous study and is additionally included here (corresponding to our layer 3, Figures 3.1, 3.2). Therefore, six layers in total were analysed in this work, each one c. $1-2 \mathrm{~cm}$ thick (except layer $3 \sim 0.15 \mathrm{~cm}$ ).
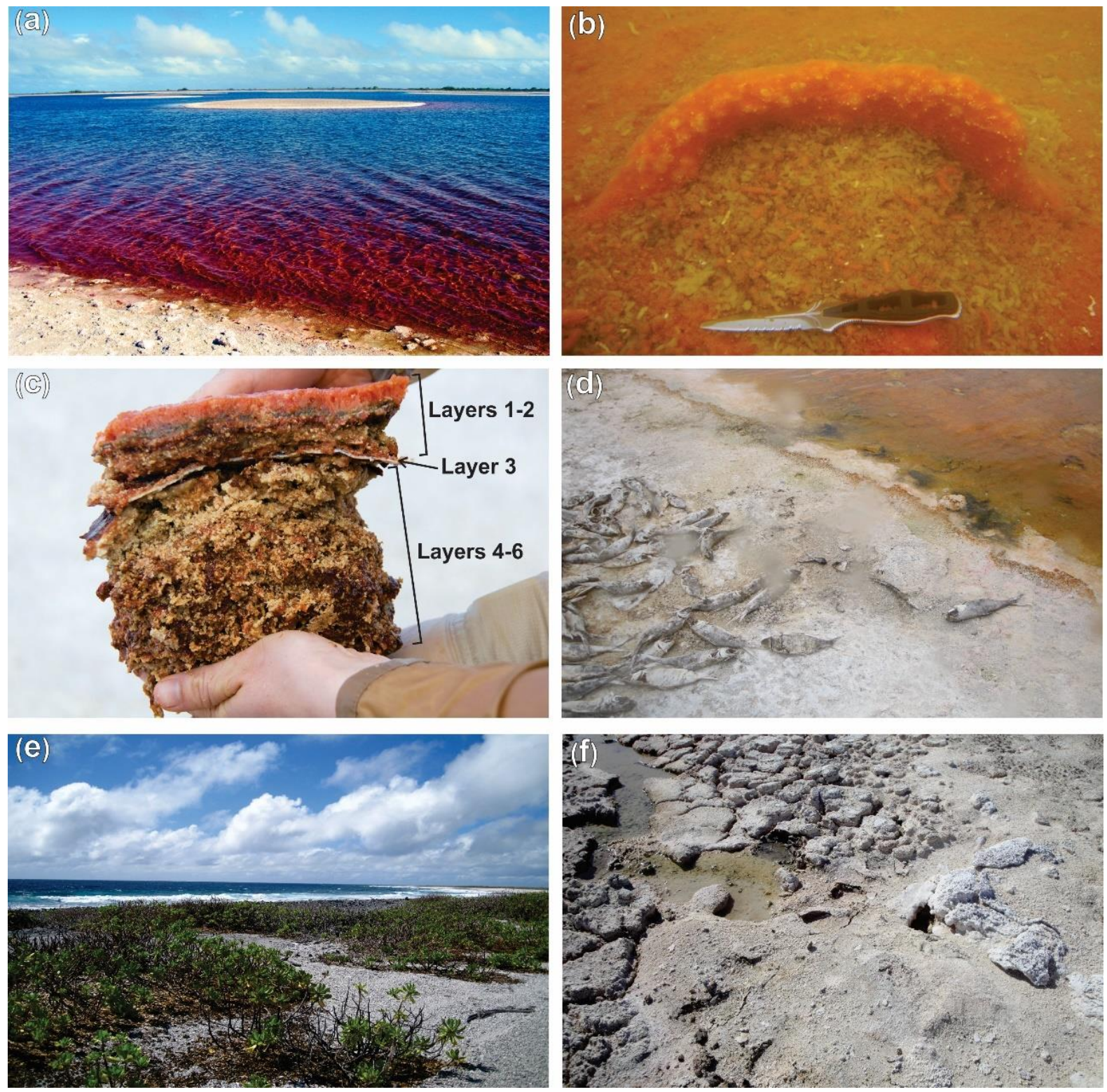

Figure 3.2 Field images: (a) general view of hypersaline Lake 2 in Kiritimati; (b) underwater photograph showing an example of a currently-active, orange-coloured microbial mat at the bottom of the lake; (c) the microbial mat sampled for this study, with clear colour-zonation; note the whitish mineral crust (Layer 3) separating the upper younger growth phase from the older, more mineralized layers; (d) lake shore showing dead fish; (e) vegetation around the lake area; (f) sampling site for hypersaline Lake 22 mat (Shen et al., 2018a). 


\subsubsection{Bulk analysis}

Homogenized (mortar) aliquots of the freeze-dried samples (both original mat layers and extraction residues) were subjected to $\mathrm{C} / \mathrm{N} / \mathrm{S}$ analysis, using a Hekatech EA $3000 \mathrm{CNS}$ analyzer and LECO RC 612 multiphase carbon analyser as described elsewhere (Shen et al., 2018a).

\subsubsection{Extraction and derivatization}

Aliquots of the freeze-dried samples (5-20 g) were homogenized and extracted using $4 \times 50 \mathrm{ml}$ portions of dichloromethane/methanol $(3: 1 ; \mathrm{V} / \mathrm{V})(10 \mathrm{~min}$ ultrasonication) to obtain the freely extractable lipids. The remaining extraction residues were decalcified using $37 \% \mathrm{HCl}$ (dropwise until $\mathrm{CO}_{2}$ development ceased), and again extracted as described above to yield the carbonate-bound lipids. The remaining extraction residues (after decalcification) were freeze dried for the analysis of bulk $\mathrm{C}_{\text {org }}$ and pyrolysis.

To make alcohols (including sterols) GC-amenable, aliquots of the lipid extracts (both freely extractable and carbonate-bound lipid fractions) were silylated using BSTFA (N,Obis(trimethylsilyl)trifluoroacetamide) containing $5 \%(\mathrm{~V} / \mathrm{V})$ trimethylchlorosilane (TMCS) as a catalyser $\left(70^{\circ} \mathrm{C}, 60 \mathrm{~min}\right)$. The resulting trimethylsilyl (TMS-) derivatives were dried under gentle $\mathrm{N}_{2}$ flow, re-dissolved in $n$-hexane, and analysed by gas chromatography-mass spectrometry (GC-MS).

To make fatty acids GC-amenable, a mixture of TMCS/MeOH (1:9, V:V) was added to all aliquots of lipid extracts and samples were heated at $80^{\circ} \mathrm{C}$ for $60 \mathrm{~min}$. The resulting fatty acid methyl esters were extracted from the reaction mixture by vigorous shaking with $3 \times 1 \mathrm{ml} \mathrm{n}$ hexane. The extracts were combined and evaporated to near-dryness under a gentle stream of $\mathrm{N}_{2}$, re-dissolved in $n$-hexane, and analysed by gas chromatography-mass spectrometry (GCMS).

\subsubsection{GC-MS}

GC-MS analyses were carried out using a Thermo Fisher Trace 1310 GC coupled to a Thermo Fisher Quantum XLS Ultra MS as described elsewhere (Shen et al., 2018a). Due to low sterol concentrations and co-elutions, particularly in the deeper mat layers, sterols were not quantified via peak integration in the total ion currents (TIC). Instead, the summed ion traces of $\left[\mathrm{m} / \mathrm{z} 129+\left(\mathrm{M}^{+}-90\right)+\mathrm{M}^{+}\right]$for the TMS-derivatives of $\Delta^{5}$ - and $\Delta^{5,22}$-stenols, and $[\mathrm{m} / \mathrm{z}$ $\left.215+\left(\mathrm{M}^{+}-90\right)+\mathrm{M}^{+}\right]$for the TMS-derivatives of stanols were used. Appropriate correction 
factors were applied according to the response of these ions $v s$. concentration in the mass spectra of standard compounds. Average standard deviations of sterol concentrations were determined from repeated analyses of sample material.

\subsubsection{Pyrolysis-gas chromatography-mass spectrometry (Py-GC-MS)}

Aliquots of the decalcified extraction residues were pyrolysed on a fast-heating Pt-filament using a Pyrola 2000 pyrolysis device (Pyrolab SB) coupled to a Varian CP3800 GC and a Varian 1200L MS as described elsewhere (Shen et al., 2018a).

\subsubsection{Compound-specific stable carbon isotopes analysis}

Compound-specific stable carbon isotope ratios were measured for sterols and fatty acids in the freely extractable lipid fractions of the microbial mat. Analyses were conducted using a Thermo Scientific Trace gas chromatograph (GC) coupled to a Delta Plus isotope ratio mass spectrometer (IRMS). The conventional $\mathrm{CuO} / \mathrm{NiO} / \mathrm{Pt}$ reactor was used and combusted at $940^{\circ} \mathrm{C}$. The GC-column used was an Agilent DB-5 coupled to an Agilent DB-1 (each $30 \mathrm{~m}$ length, $250 \mu \mathrm{m}$ internal diameter, and $0.25 \mu \mathrm{m}$ film thickness). Lipid fractions were injected into a splitless injector and transferred to the $\mathrm{GC}$ column at $290^{\circ} \mathrm{C}$. The carrier gas was helium at a flow rate of $1.2 \mathrm{ml} / \mathrm{min}$. The temperature program for analyzing lipid fractions was ramped from $80^{\circ} \mathrm{C}$, followed by heating to $325^{\circ} \mathrm{C}$ (at $5^{\circ} \mathrm{C} / \mathrm{min}$, held for $60 \mathrm{~min}$ ). Analysis of laboratory standards were carried out to control the reproducibility of measuring conditions and measurements were calibrated by using $\mathrm{CO}_{2}$ gas of known isotopic composition.

\subsection{Results}

\subsubsection{General characterization of the microbial mat}

The microbial mat has a thickness of c.10 cm. Based on its macroscopic appearance it shows two major phases of development. The upper, younger growth phase is represented by layer 1 (photosynthetically active mat) and layer 2 (each c. $1 \mathrm{~cm}$ thick, Figures 3.1, $\underline{3.2}$ ). These layers have a cohesive texture, sticking together when handled, due to abundant and relatively fresh organic material (i.e. EPS) of bright orange, green and brown colours. Layer 1 includes small and scarce mineral precipitates, whereas layer 2 shows more abundant whitish minerals within its organic matrix (Figure 3.2c). Layer 2 is underlain by a thin but distinctive, laterally continuous mineral crust (layer 3). Below the crust, layers 4, 5 and 6 (c. $7 \mathrm{~cm}$ thick in total, Figures $3.1, \underline{3.2}$ ) are more friable, having a crumbly appearance, due to a higher abundance of 
mineral particles as compared to EPS. In this older growth phase, brown and beige colours predominate (Figure 3.2c). The minerals observed within the mat layers are mainly aragonite $\left(\mathrm{CaCO}_{3}\right)$, with minor amounts of gypsum $\left(\mathrm{CaSO}_{4}\right)$ found only in the uppermost layer 1 (Shen et al., 2018b). Previously reported ${ }^{14} \mathrm{C}$ ages of the mat (Blumenberg et al., 2015) show that its upper growth phase formed in approximately 1000 years $(62 \pm 40$ years BP for layer $1,551 \pm 40$ years BP for layer 2 and $1111 \pm 40$ years BP for layer 3; Figure 3.1b) whereas the older (and thicker) growth phase formed approximately in the preceding 300 years (1331 \pm 40 years BP for layer 5 and $1440 \pm 40$ years BP for layer 6; Figure 3.1b).

\subsubsection{Bulk geochemical data}

Bulk geochemical data for individual mat layers are shown in Table 3.1a. In the original mat (i.e. bulk sample before decalcification) relatively high $\mathrm{C}_{\text {org }}$ contents were observed in layers 1 and 2 (4.7 and $6.2 \%$, respectively; Table 3.1a and Figure 3.3a), consistent with a more fresh, cohesive appearance of the organic matrix in these layers. Below layer 2, the earlier growth phase consistently showed low and constant $\mathrm{C}_{\text {org }}$ contents $<2 \%$, with the lowest value found for layer 6 (1.2\%) (see section 3.3.1). The $\mathrm{CaCO}_{3}$ content of the mat increased significantly with depth (Figure 3.3a; Table 3.1a). The lowest value was observed in the top layer 1 $(27.1 \%)$, a strong enrichment occurred in layer $2(73.1 \%)$, and constantly high contents $>90 \%$ were found for all deeper mat layers. This is consistent with the observation of more abundant mineral precipitates downwards in the mat. The highest $\mathrm{S}$ content was detected for layer 1 $(9.8 \%)$, due to gypsum precipitates. Below, S decreased sharply (1.2\% in layer 2) and retained low values $(<1 \%)$ in the earlier growth phase of the mat $(\sim 0.3-0.5 \%)$. N showed generally low contents $(0.14-0.75 \%)$ throughout the mat.

In the decalcified extraction residues (i.e., extraction residues after decalcification; Table $\underline{3.1 \mathrm{~b}}), \mathrm{C}_{\text {org }}$ showed a broad range but increased significantly with depth, with the highest value observed in layer 6 (42.3\%; also see Figure 3.3b). $\mathrm{N}$ was likewise enhanced in the deeper parts, with the highest amount found in layer 5 (6.7 \%). By contrast, a decrease in S content was observed with depth, with highest values occurring in the topmost mat layer $1(10.4 \%)$. 

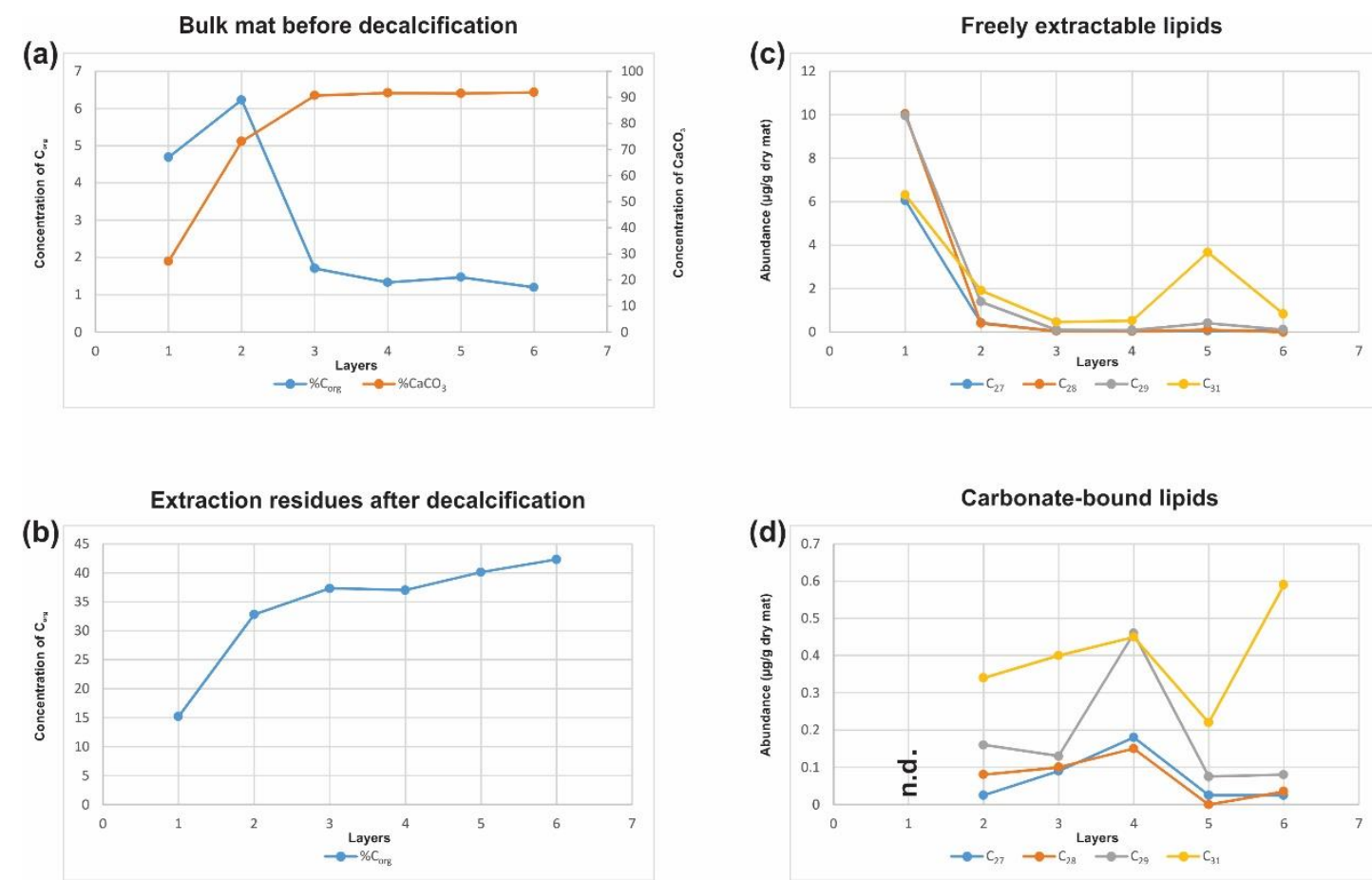

Figure 3.3 (a) $\mathrm{C}_{\text {org }}$ and $\mathrm{CaCO}_{3}$ contents of the bulk mat (\% ${ }_{\mathrm{wt}}$ ); (b) $\mathrm{C}_{\text {org }}$ content of the extraction residues after decalcification $\left(\%_{\mathrm{wt}}\right)$; (c) Distribution of $\mathrm{C}_{27^{-}}$vs. $\mathrm{C}_{28}-\mathrm{vs} . \mathrm{C}_{29}-\mathrm{vs} . \mathrm{C}_{31}$ - sterols in the freely extractable lipids ( $\mu \mathrm{g} / \mathrm{g}$ dry mat); (d) Distribution of $\mathrm{C}_{27^{-}}$vs. $\mathrm{C}_{28^{-}}$vs. $\mathrm{C}_{29^{-}}$- vs. $\mathrm{C}_{31}$ - sterols in the carbonate-bound lipids of the microbial mat $(\mu \mathrm{g} / \mathrm{g}$ dry mat).

Table 3.1a Bulk geochemical data for the microbial mat (original mat layers before decalcification).

\begin{tabular}{|c|c|c|c|c|c|c|c|c|}
\hline Layers & $\mathbf{C}_{\text {tot }}(\boldsymbol{\%})$ & $\mathbf{C}_{\text {org }}(\boldsymbol{\%})$ & $\mathbf{C}_{\text {carb }}(\boldsymbol{\%})$ & $\begin{array}{c}\mathbf{C a C O}_{\mathbf{3}} \\
(\boldsymbol{\%})\end{array}$ & $\mathbf{N}_{\text {tot }}(\boldsymbol{\%})$ & $\mathbf{S}_{\text {tot }}(\boldsymbol{\%})$ & $\mathbf{C}_{\text {org }} / \mathbf{N}$ & $\mathbf{C}_{\text {org }} / \mathbf{S}$ \\
\hline 1 & 7.94 & 4.69 & 3.25 & 27.10 & 0.41 & 9.78 & 11.40 & 0.50 \\
\hline 2 & 15.00 & 6.23 & 8.77 & 73.10 & 0.74 & 1.21 & 8.40 & 5.20 \\
\hline 3 & 12.59 & 1.71 & 10.88 & 90.70 & 0.16 & 0.33 & 10.50 & 5.10 \\
\hline 4 & 12.33 & 1.33 & 11.00 & 91.70 & 0.19 & 0.49 & 7.00 & 2.70 \\
\hline 5 & 12.45 & 1.47 & 10.98 & 91.50 & 0.20 & 0.52 & 7.30 & 2.80 \\
\hline 6 & 12.23 & 1.20 & 11.03 & 91.90 & 0.14 & 0.48 & 8.50 & 2.50 \\
\hline
\end{tabular}

Table 3.1b Bulk geochemical data for the microbial mat (extraction residues after decalcification; modified after Blumenberg et al., 2015).

\begin{tabular}{|c|c|c|c|c|c|}
\hline Layers & $\mathbf{C}_{\text {org }}(\boldsymbol{\%})$ & $\mathbf{N}_{\text {tot }}(\boldsymbol{\%})$ & $\mathbf{S}_{\text {tot }}(\boldsymbol{\%})$ & $\mathbf{C}_{\text {org }} \mathbf{~} \mathbf{N}$ & $\mathbf{C}_{\text {org }} / \mathbf{S}$ \\
\hline 1 & 15.2 & 1.9 & 10.4 & 7.9 & 1.5 \\
\hline 2 & 32.8 & 4.9 & 2.9 & 6.7 & 11.4 \\
\hline 3 & 37.3 & 5.6 & 4.6 & 6.7 & 8.2 \\
\hline 4 & 37.0 & 6.2 & 2.6 & 6.0 & 14.4 \\
\hline 5 & 40.1 & 6.7 & 2.0 & 6.0 & 20.3 \\
\hline 6 & 42.3 & 6.6 & 2.0 & 6.4 & 21.4 \\
\hline
\end{tabular}




\subsubsection{Sterol distributions and concentrations}

Various sterols were detected within the mat, including saturated sterols (stanols; $\mathrm{C}_{27} \Delta^{0}$, $\mathrm{C}_{28} \Delta^{0}, \mathrm{C}_{29} \Delta^{0}, \mathrm{C}_{31} \Delta^{0}$ ) and unsaturated sterols (stenols; $\mathrm{C}_{27} \Delta^{5}, \mathrm{C}_{28} \Delta^{5,22}, \mathrm{C}_{28} \Delta^{5}, \mathrm{C}_{29} \Delta^{5,22}, \mathrm{C}_{29} \Delta^{5}$, $\mathrm{C}_{31} \Delta^{5}$, see Figure 3.4; Table 3.2). Based on the retention characteristics and comparison with published mass spectra (Atwood et al., 2014; Houle et al., In Press), the $\mathrm{C}_{31}$ sterols were identified as 22,23-methylene-4 $\alpha, 23,24$-trimethylcholest-5-en-3 $\beta$-ol ( $4 \alpha$-methylgorgosterol)

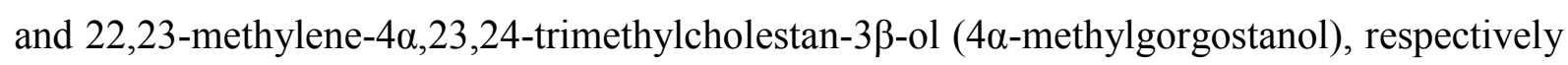
(see Figure B.1).
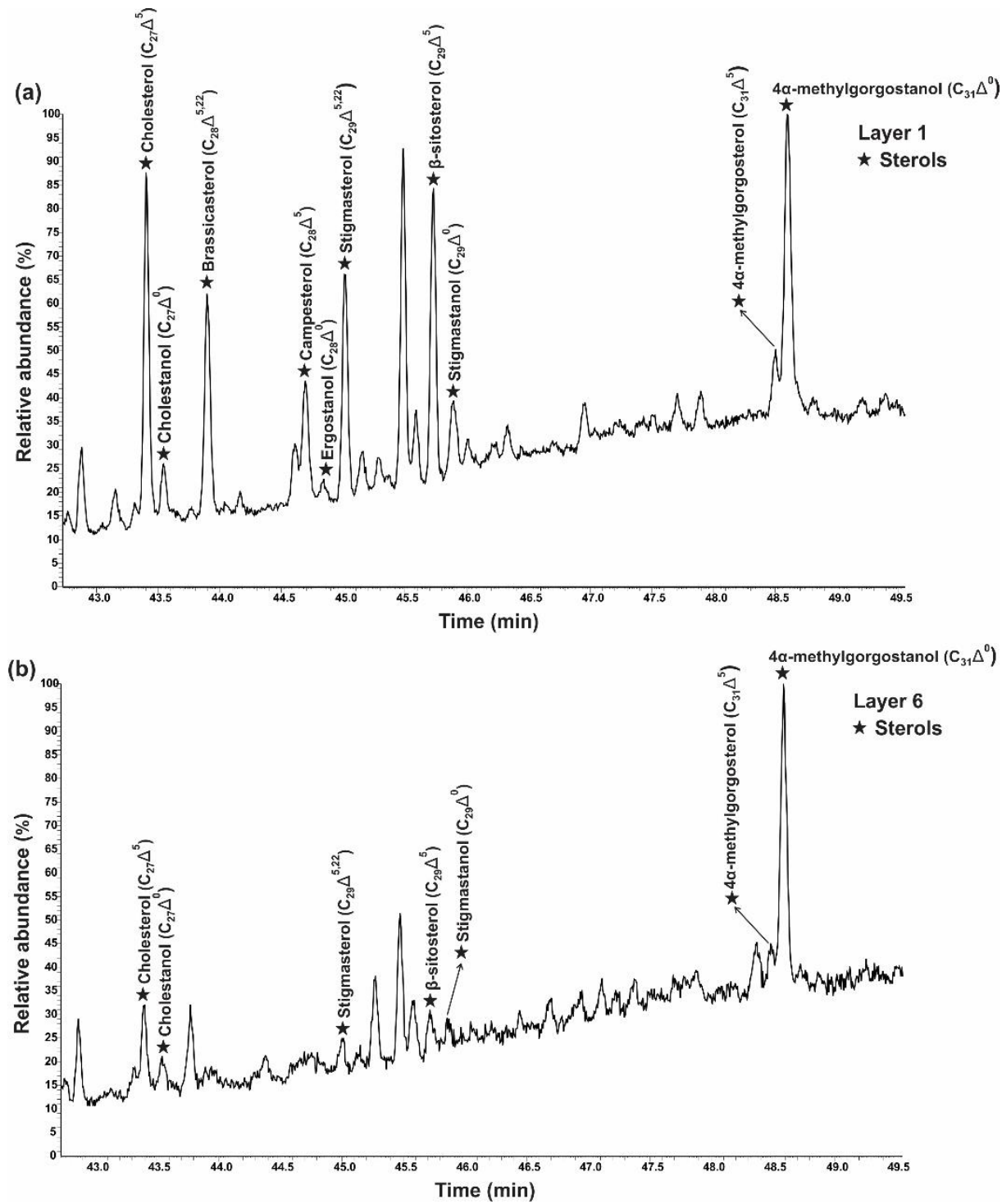

Figure 3.4 Partial GC-MS chromatograms (total ion current) showing the distributions of freely extractable sterols (TMS-derivatives) in (a) layer 1, and (b) layer 6 of the microbial mat. 
Table 3.2a Concentrations of sterols in the freely extractable lipids of the microbial mat layers. SD indicate mean value of standard deviation $(\mu \mathrm{g} / \mathrm{g}$ dry mat; $\mathrm{n} . \mathrm{d} .=\mathrm{not}$ detected).

\begin{tabular}{|c|c|c|c|c|c|c|c|c|c|c|}
\hline Trivial names & Cholesterol & Cholestanol & Brassicasterol & Campesterol & Ergostanol & Stigmasterol & $\beta$-sitosterol & Stigmastanol & $\begin{array}{c}4 \alpha- \\
\text { methylgorgoste } \\
\text { rol }\end{array}$ & $\begin{array}{c}4 \alpha- \\
\text { methylgorgosta } \\
\text { nol }\end{array}$ \\
\hline Compound & 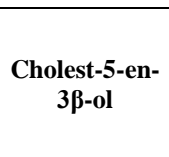 & 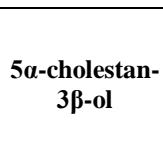 & 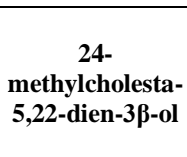 & 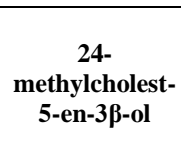 & $\begin{array}{c}\text { 5a-24- } \\
\text { methylcholesta } \\
\text { n-3p-ol }\end{array}$ & 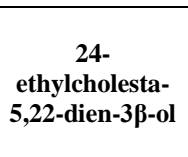 & 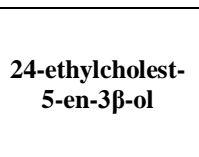 & $\begin{array}{c}5 \alpha-24- \\
\text { ethylcholestan- } \\
3 \beta-0 l\end{array}$ & 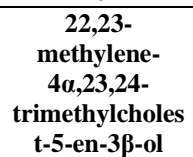 & $\begin{array}{c}22,23- \\
\text { methylene- } \\
4 \alpha, 23,24- \\
\text { trimethylcholes } \\
\text { tan-3B-ol }\end{array}$ \\
\hline Layers & $28.4 \%$ & $41.7 \%$ & $12.31 \%$ & $10.7 \%$ & $28.3 \%$ & $20.0 \%$ & $13.2 \%$ & $27.7 \%$ & $41.3 \%$ & $41.6 \%$ \\
\hline 1 & 5.20 & 0.86 & 4.93 & 4.91 & 0.20 & 3.74 & 5.44 & 0.77 & 1.10 & 5.21 \\
\hline 2 & 0.24 & 0.19 & n.d. & 0.34 & 0.06 & 0.43 & 0.77 & 0.19 & 0.36 & 1.55 \\
\hline 3 & 0.01 & 0.04 & n.d. & 0.02 & 0.02 & 0.02 & 0.03 & 0.05 & 0.09 & 0.37 \\
\hline 4 & 0.02 & $<0.01$ & n.d. & 0.02 & 0.01 & 0.05 & 0.02 & 0.02 & 0.12 & 0.40 \\
\hline 5 & 0.03 & 0.02 & n.d. & 0.07 & 0.04 & 0.16 & 0.12 & 0.13 & 0.95 & 2.72 \\
\hline 6 & 0.08 & $<0.01$ & n.d. & n.d. & n.d. & 0.08 & 0.02 & 0.01 & 0.10 & 0.73 \\
\hline
\end{tabular}

Table 3.2b Concentrations of sterols in the carbonate-bound lipids of the microbial mat layers. SD indicate mean value of standard deviation $(\mu \mathrm{g} / \mathrm{g}$ dry mat; $\mathrm{n} . \mathrm{d} .=\mathrm{not}$ detected; dashes indicate SD are not applicable).

\begin{tabular}{|c|c|c|c|c|c|c|c|c|c|c|}
\hline Trivial names & Cholesterol & Cholestanol & Brassicasterol & Campesterol & Ergostanol & Stigmasterol & $\beta$-sitosterol & Stigmastanol & $\begin{array}{c}4 \alpha- \\
\text { methylgorgoste } \\
\text { rol } \\
\end{array}$ & $\begin{array}{c}4 \alpha- \\
\text { methylgorgosta } \\
\text { nol } \\
\end{array}$ \\
\hline Compound & 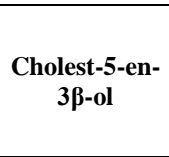 & 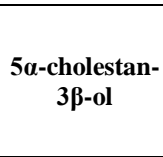 & 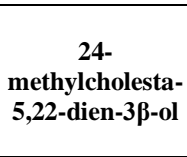 & 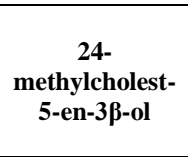 & 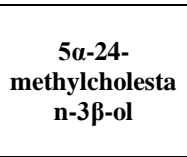 & 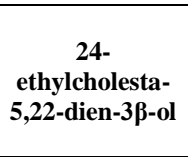 & $\begin{array}{l}\text { 24-ethylcholest- } \\
\text { 5-en-3ß-ol }\end{array}$ & $\begin{array}{c}5 \alpha-24- \\
\text { ethylcholestan- } \\
3 \beta-o l\end{array}$ & 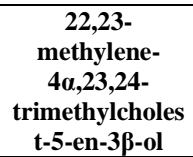 & $\begin{array}{c}22,23- \\
\text { methylene- } \\
4 \alpha, 23,24- \\
\text { trimethylcholes } \\
\text { tan-3ß-ol }\end{array}$ \\
\hline Layers & $24.0 \%$ & $47.6 \%$ & $-{ }_{-}^{-}$ & -- & $-{ }_{-}^{-}$ & -- & $24.8 \%$ & $40.2 \%$ & -- & -- \\
\hline 1 & n.d. & n.d. & n.d. & n.d. & n.d. & n.d. & n.d. & n.d. & n.d. & n.d. \\
\hline 2 & 0.02 & $<0.01$ & n.d. & 0.08 & $<0.01$ & 0.08 & 0.07 & 0.01 & n.d. & 0.34 \\
\hline 3 & 0.04 & 0.05 & n.d. & 0.08 & 0.02 & 0.03 & 0.06 & 0.04 & n.d. & 0.40 \\
\hline 4 & 0.11 & 0.07 & n.d. & 0.12 & 0.03 & 0.25 & 0.12 & 0.09 & n.d. & 0.45 \\
\hline 5 & 0.02 & $<0.01$ & n.d. & n.d. & n.d. & 0.06 & 0.01 & $<0.01$ & n.d. & 0.22 \\
\hline 6 & 0.02 & $<0.01$ & n.d. & 0.03 & $<0.01$ & 0.04 & 0.03 & 0.01 & n.d. & 0.59 \\
\hline
\end{tabular}



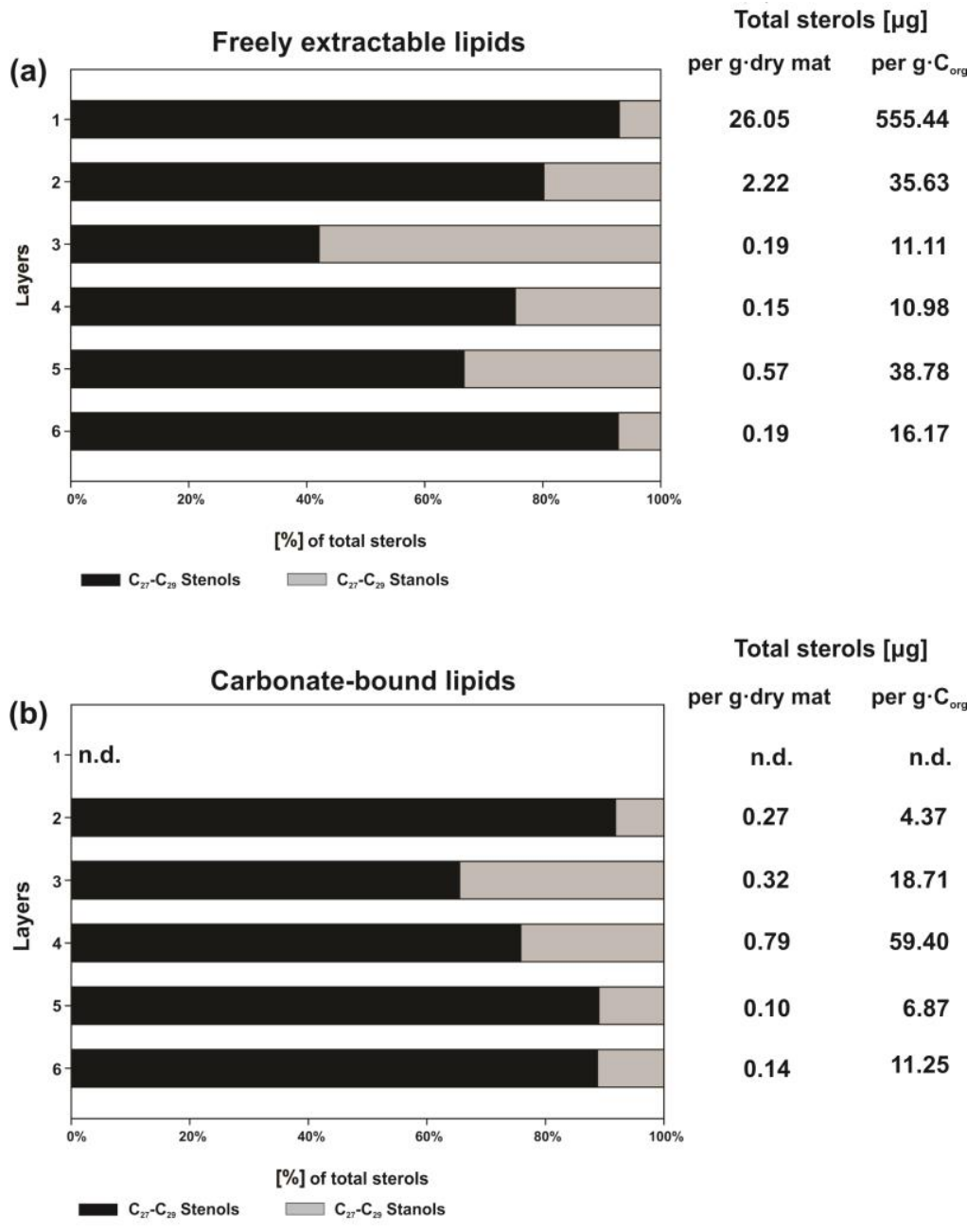

Total sterols $[\mu \mathrm{g}]$ per $g$.dry mat per $\mathbf{g} \cdot \mathrm{C}_{\text {org }}$ n.d. n.d. $0.27 \quad 4.37$ $0.32 \quad 18.71$

Figure 3.5 Distributions and concentrations of $\mathrm{C}_{27}-\mathrm{C}_{29}$ sterols in the microbial mat layers, (a) freely extractable lipids, and (b) carbonate-bound lipids.

In the freely extractable lipids, stenols were by about an order more abundant than stanols. Both groups showed highest concentrations in layer 1, and a major decrease with depth (see Table 3.2a). Figure 3.5a shows the variations of $\mathrm{C}_{27}-\mathrm{C}_{29}$ sterols (e.g. stenols vs.stanols) in the freely extractable lipids through the mat profile. The highest abundance of sterols occurred in the topmost layer $1(26.05 \mu \mathrm{g} / \mathrm{g}$ dry mat, see Figure 3.5a). Concentrations decreased drastically in the upper layers, and remained low from layer 3 onwards. $C_{28}$ and $C_{29}$ sterols were the most dominant sterols in layer 1 while the $\mathrm{C}_{31}$ sterols dominated in the deeper layers (Figure B.3). The $\mathrm{C}_{31}$-sterol distributions differed from the other sterol distributions identified in this mat, with concentrations in layer 5 being three to ten times higher than in layers 3,4 and 6 (Figure 3.3c; Table 3.2a). Further, in the freely extractable lipids, the ratios of $5 \alpha-$ stanols to their corresponding $\Delta^{5}$-stenols (stanol/stenol ratios) showed no consistent trend 
within the profile (Figure 3.6a; Table 3.3). As expected, the $\mathrm{C}_{27^{-}}, \mathrm{C}_{28^{-}}$and $\mathrm{C}_{29^{-}}$ratios increased in the upper, younger growth phase of the mat, with the highest value observed for layer 3, but decreased again in the deeper, older growth phase (Figure 3.6; Table 3.3). In contrast, stanol/stenol ratios for the $\mathrm{C}_{31}$ sterol declined from layer 1 to layer 5 , and showed a remarkable increase in layer 6.
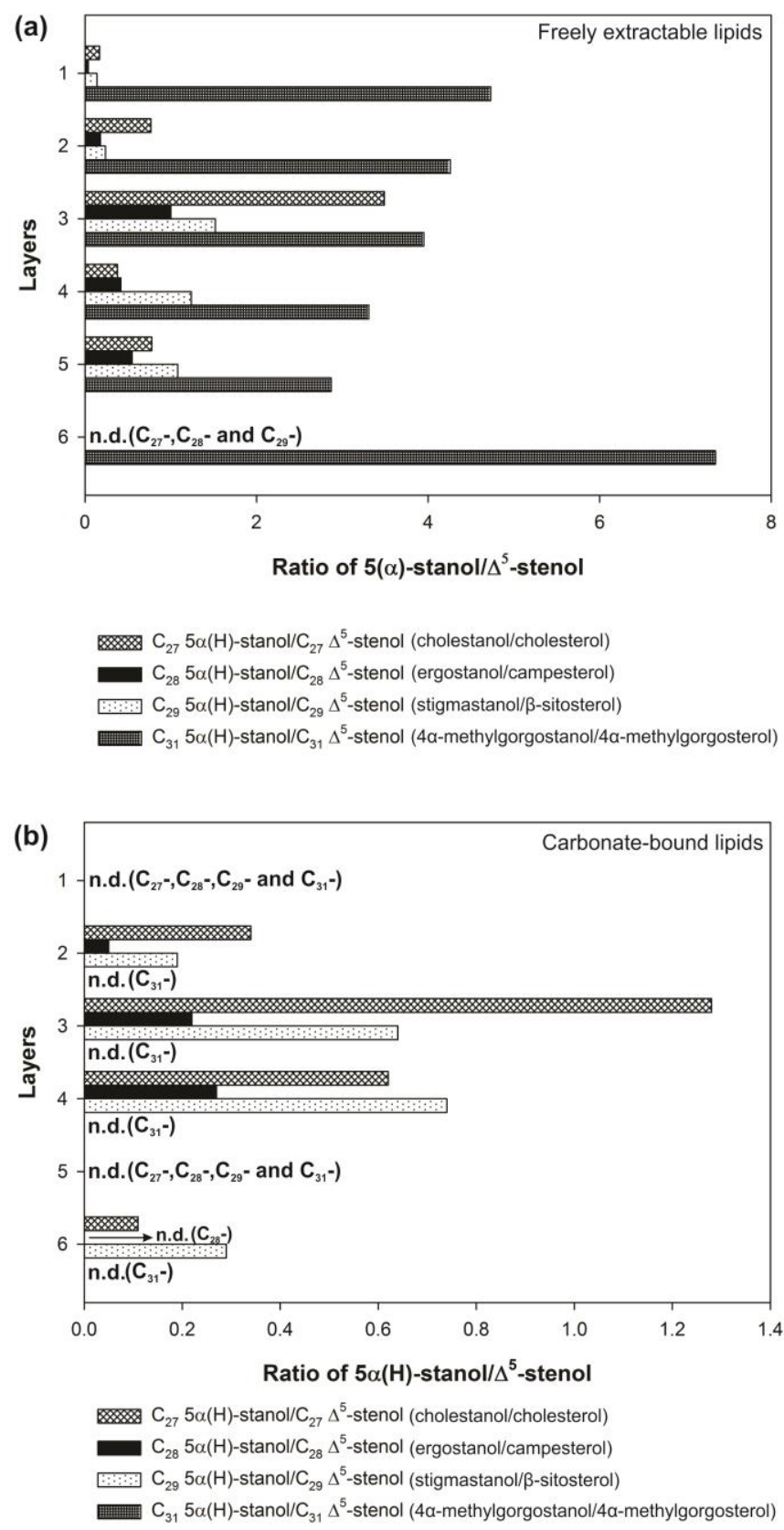

Figure 3.6 Stanol/stenol ratios for the microbial mat layers, (a) freely extractable lipids, and (b) carbonatebound lipids. 
Sterol concentrations in the carbonate-bound lipid fractions are given in Table $3.2 \mathrm{~b}$. In the topmost layer 1, no carbonate-bound sterols were observed. In mat layers 2 and 3, carbonatebound sterols occurred, but were still much less abundant as freely extractable sterols (below detection limit to $\sim 10^{-2} \mu \mathrm{g} / \mathrm{g}$ dry mat). In the deeper mat layers (4-6), however, sterols showed similar absolute concentrations $\left(\sim 10^{-2}-10^{-3} \mu \mathrm{g} / \mathrm{g}\right.$ dry mat $)$ in both, the carbonate-bound and the freely extractable fractions. Sterenes were also detected in both lipid pools, but only at trace abundances (not discussed further).

In the carbonate-bound lipids, stenols comprised the predominant portion (c. from $65 \%$ up to $90 \%$ of all sterols) ( Figure 3.5b). Overall low abundances of carbonate-bound sterols were observed throughout the mat $\left(10^{-1} \mu \mathrm{g} / \mathrm{g}\right.$ dry mat range). $\mathrm{C}_{31^{-}}$groups were the primary contributors in both lipid fractions (ranging up to ca. $85 \%$ in the deeper part of the mat), and $\mathrm{C}_{29^{-}}$groups were the second major inputs (Figure B.3). Carbonate-bound $\mathrm{C}_{31}$-sterols increased in the bottom layer 6, which is distinguished from the other sterols (Figure 3.3d). The stanol/stenol ratios in the carbonate-bound lipids, increased for the $\mathrm{C}_{27^{-}}, \mathrm{C}_{28^{-}}$and $\mathrm{C}_{29^{-}}$ pairs between layers 1 and 3, and again decreased downwards as they did in the freely extractable lipids (see Figure 3.6b; Table 3.3). No stanol/stenol ratios could be obtained for the carbonate-bound $\mathrm{C}_{31}$ sterols, as $\mathrm{C}_{31}$ stenols were virtually absent throughout the mat.

Table 3.3 Stanol/stenol ratios in the freely extractable lipids and carbonate-bound lipids for the microbial mat layers (n.d. = not determined, due to very low concentration of sterols).

\begin{tabular}{|c|c|c|c|c|c|c|c|c|}
\hline \multirow{2}{*}{ Layer } & \multicolumn{3}{|c|}{ stanol/stenol $\left(\boldsymbol{\Delta}^{\mathbf{0}} \boldsymbol{\Delta}^{\mathbf{5}}\right)$ in Free lipids } & \multicolumn{3}{c|}{ stanol/stenol $\left(\boldsymbol{\Delta}^{\mathbf{0}} \boldsymbol{\Delta}^{\mathbf{5}}\right)$ in carbonate-bound } \\
\cline { 2 - 10 } & $\mathbf{C}_{\mathbf{2 7}}$ & $\mathbf{C}_{\mathbf{2 8}}$ & $\mathbf{C}_{\mathbf{2 9}}$ & $\mathbf{C}_{\mathbf{3 1}}$ & $\mathbf{C}_{\mathbf{2 7}}$ & $\mathbf{C}_{\mathbf{2 8}}$ & $\mathbf{C}_{\mathbf{2 9}}$ & $\mathbf{C}_{\mathbf{3 1}}$ \\
\hline 1 & 0.17 & 0.04 & 0.14 & 4.73 & n.d. & n.d. & n.d. & n.d. \\
\hline 2 & 0.77 & 0.18 & 0.24 & 4.26 & 0.34 & 0.05 & 0.19 & n.d. \\
\hline 3 & 3.49 & 1.00 & 1.52 & 3.95 & 1.28 & 0.22 & 0.64 & n.d. \\
\hline 4 & 0.38 & 0.42 & 1.24 & 3.31 & 0.62 & 0.27 & 0.74 & n.d. \\
\hline 5 & 0.78 & 0.55 & 1.08 & 2.87 & n.d. & n.d. & n.d. & n.d. \\
\hline 6 & n.d. & n.d. & n.d. & 7.35 & 0.11 & n.d. & 0.29 & n.d. \\
\hline
\end{tabular}

\subsubsection{Pyrolysis}

Ion chromatograms representing steroids (i.e., including sterenes, steranes and sterols) and hopanoids released by pyrolysis of the decalcified extraction residues are shown in Figure B.2. Steroids were not observed in the pyrolysates throughout the mat, while hopanoids were found in the insoluble matter of each mat layer. Notably, only small amounts of hopanoid moieties were observed in the pyrolysates of layer 1 , but their abundance gradually increased with depth. 


\subsubsection{Compound-specific $\delta^{13} \mathrm{C}$ values}

A reliable compound-specific $\delta^{13} \mathrm{C}$ value could be obtained for the coeluting $\mathrm{C}_{31}$-sterols from the freely extractable lipids in layer 1 . This compound showed a strong enrichment in ${ }^{13} \mathrm{C}$ $\left(\delta^{13} \mathrm{C}=-7.2 \%\right.$ ). Fatty acids (including $\mathrm{C}_{14}-\mathrm{C}_{19}$ homologues) showed similarly high $\delta^{13} \mathrm{C}$ values ranging from -4.4 to $-11.7 \%$.

\subsection{Discussion}

\subsubsection{Biological sources of sterols}

The studied mat contained a broad variety of $\mathrm{C}_{27}-\mathrm{C}_{29}$ sterols as well as two $\mathrm{C}_{31}$ sterols, indicating potential sources like animals $\left(\mathrm{C}_{27}\right)$, fungi $\left(\mathrm{C}_{28}\right)$, algae including dinoflagellates $\left(\mathrm{C}_{27}-\mathrm{C}_{29}+\mathrm{C}_{31}\right)$ and terrestrial plants $\left(\mathrm{C}_{29}\right)$ (Atwood et al., 2014; Houle et al., In Press; Volkman, 1986; Volkman, 2003). The concentrations of freely extractable sterols in the topmost layer 1 in the studied Lake 2 mat are similar to Lake $2 \mathrm{~A}$ and Lake $22\left(\sim 10^{2}-10^{3} \mu \mathrm{g} / \mathrm{g}\right.$ $\mathrm{C}_{\text {org}}$; Bühring et al., 2009; Shen et al., 2018a; see Figure 3.5a). However, sterols in the deeper layers are much less abundant in the Lake 2 mat as compared to other mats in Kiritimati lakes.

Figure B.3 shows the relative distribution of summed $\mathrm{C}_{27}$ - vs. $\mathrm{C}_{28}-$ vs. $\mathrm{C}_{29}-$ vs. $\mathrm{C}_{31}-$ sterols in the microbial mat layers. In both lipid fractions, the $\mathrm{C}_{31}$-sterols are predominant, suggesting inputs from dinoflagellates (Atwood et al., 2014; Houle et al., In Press). $\mathrm{C}_{29}$-sterols make up the next most abundant group, potentially indicating contributions from either algae or terrestrial plants (Volkman, 1986); also these compounds are known to be produced by diatoms and other algal groups (Rampen et al., 2010; Volkman, 2003).

The high $\delta^{13} \mathrm{C}$ value of $-7.2 \%$ for the $\mathrm{C}_{31}$-sterols, and similarly high values for the fatty acids measured from layer 1, imply that the carbon source of these compounds was autochthonous and derived from the hypersaline, $\mathrm{CO}_{2}$-limited ecosystem of Lake 2 (cf. Schouten et al., 2001). Previous work on carbon isotope compositions of sterols in a mat from the adjacent Kiritimati Lake $2 \mathrm{~A}$ showed $\delta^{13} \mathrm{C}$ values from -19 to $-23 \%$ (Bühring et al., 2009). In addition, Trichet et al. (2001) reported $\delta^{13} \mathrm{C}$ values for sedimentary bulk OM from -14 to $17 \%$ in Kiritimati Lake 30. Both studies showed more depleted values than those observed for Lake 2. An explanation could be a better $\mathrm{CO}_{2}$ exchange in those lakes, due to their shallow water layer (a maximum depth of $0.2 \mathrm{~m}$ in Lake 2A, Bühring et al., 2009; depth of $0.9 \mathrm{~m}$ in Lake 30, Trichet et al., 2001), leading to the relatively light $\delta^{13} \mathrm{C}$ signatures. Another explanation could be that shrinking lake water bodies caused by La Niña dry events are often 
associated with massive increases in lake salinities (Trichet et al., 2001). For instance, Lake 2A (Bühring et al., 2009) was observed to be nearly dried out during our sampling campaign in 2011. The increasing salinities may result in a $\mathrm{CO}_{2}$-limited ecosystem, leading to enrichment in ${ }^{13} \mathrm{C}$. The resulting reinforced $\mathrm{CO}_{2}$-limitation in Lake 2 is not only reflected by the high $\delta^{13} \mathrm{C}$ values of sterols and fatty acids in this work, but also $\delta^{13} \mathrm{C}$ values of carbonates that were observed to be as high as $+6 \%$ (Arp et al., 2012).

\subsubsection{Taphonomy of sterols}

The sterols in the studied mat are probably sourced from plankton or organisms thriving at the mat surface, because eukaryotes are generally depending on an oxygenated environment and would hardly thrive in anoxic, deeper parts of the mat. It can also be expected that sterols were initially introduced as stenols. Subsequent alteration by early diagenetic processes within the mat would have resulted in a variety of sterol transformation products. Reduction of $\Delta^{5}$-stenols to $5 \alpha$-stanols (hydrogenation) is a known result of anaerobic microbial degradation (Rosenfeld and Hellman, 1971; Wakeham, 1989). Consequently, stanol/stenol ratios may reflect the extent of microbial stenol alteration under anoxic conditions (i.e. under low redox potential; Gaskell and Eglinton, 1975; Nishimura, 1977; Wakeham, 1989). Several investigations have reported such conversion in microbial mats (Grimalt et al., 1992; Scherf and Rullkötter, 2009; Słowakiewicz et al., 2016), including some mats from other lakes on Kiritimati (Bühring et al., 2009; Shen et al., 2018a).

In the mat studied, stanol/stenol ratios for $\mathrm{C}_{27}-\mathrm{C}_{29}$ pairs initially increased with depth and showed highest values in layer 3, suggesting low redox potentials and a pronounced anaerobic microbial transformation of stenols therein. In the deeper layers (4-6), ratios decreased again. We interpret this to result from a more efficient microbial OM degradation, which occurred under higher redox potentials during the more rapid accretion of the earlier growth phase of the mat (1440-1111 years BP, see Figure 3.1b). This idea is supported by constantly lower $\mathrm{C}_{\text {org }}$ contents in the earlier growth phase of the mat (1.20-1.47\%, see Table 3.1a). Exclusively for the $\mathrm{C}_{31}$-stanol/stenol ratios, they showed a steady decrease with depth but sharply increased again in the bottom layer 6 . It could be possible that input variations of the $\mathrm{C}_{31}$ stanol and stenol played a more important role than microbial alteration for the distributions of $\mathrm{C}_{31}$ sterols. $4 \alpha$-methylgorgostanol has been reported in a few dinoflagellate species belonging to the genera Peridinium, Alexandrium and Pyrodinium, (Atwood et al., 2014; Houle et al., In Press, and refs therein), and the mass spectra of the sterol we tentatively 
identified as $4 \alpha$-methylgorgosterol is similar to that reported for a sterol occurring in resting cysts but not in the motile cells of the dinoflagellate Peridinium umbonatum var. inaequale (Amo et al., 2010). As a result, $\mathrm{C}_{31}$ sterols could partly have been derived from sedimentary resting cysts that may have been less affected by degradation during transport or microbial recycling than conventional $\mathrm{C}_{27}-\mathrm{C}_{29}$ sterols. It may also be speculated that the unusual sidechain structure and methylation pattern of $4 \alpha$-methylgorgosterols hamper enzymatic microbial degradation (e.g. Giner et al., 2003, and refs therein). The steadily increasing relative abundances of $\mathrm{C}_{31}-v s . \mathrm{C}_{27}-\mathrm{C}_{29}$ sterols in the mat profile (Figure B.3) suggest that $\mathrm{C}_{31}$ sterols experienced different degradation patterns as compared to conventional sterols.

For the total sterols, concentrations of freely extractable sterols were high in the top layer but dropped sharply immediately below and kept at very low concentrations throughout the deeper mat $(<1 \mu \mathrm{g} / \mathrm{g}$ dry mat). Carbonate-bound sterols, on the other hand, were hardly detectable at the top of the mat, and likewise showed constantly low abundances below. These observations suggest that (i) freely extractable sterols are rapidly degraded in the upper layers of the mat and (ii) the carbonate matrix played no important role in encasing (i.e., preserving) sterols in this mat. This is in agreement with previous reports about minor amounts of such sterols in methane seep microbialites and ooids (Birgel et al., 2006; Thiel et al., 1999; Thiel et al., 2001; Summons et al., 2013). However, in those settings, high concentrations of microbial lipids preserved in the carbonate matrix possibly reflect a constructive role of their source organisms in carbonate formation and/or their continuous incorporation into carbonate during the precipitation processes (Summons et al., 2013; O'Reilly et al., 2017). For instance, abundant ${ }^{13} \mathrm{C}$-depleted acyclic isoprenoids encased in ancient methane-derived carbonates have been shown to originate from methane-oxidizing archaea whose metabolism immediately enhanced calcification (Peckmann and Thiel, 2004).

Blumenberg et al. (2015) pointed out that organic compounds in the deeper parts of the Lake 2 mat, unlike those at the top, are better preserved in the insoluble OM fraction, which is concordant with the results in this work (Figure B.2). Specifically, our pyrolysis of the decalcified extraction residues revealed that steroids were not sequestered into insoluble OM, while hopanoids were present in all mat layers (Figure B.2). This phenomenon was also observed for pyrolysates in Lake 22 mat (Shen et al., 2018a). An explanation could be that the low number of reactive sites in common sterols (i.e. one hydroxyl-group) would lead to a low tendency to incorporate into macromolecular $\mathrm{OM}$ as compared to hopanoids (e.g. highly functionalized bacteriohopanepolyols with several hydroxyl-groups). This behaviour may 
eventually give rise to a further preservational bias of steroids $v s$. hopanoids over geological time.

In the Lake 2 mat studied here, the strong decline in freely extractable sterols below the uppermost mat layer, along with the lack of any significant carbonate incorporation, suggests major degradation of steroids vs. hopanoids during early diagenesis (i.e. on a timescale of $10^{2}-10^{3}$ years).

\subsubsection{Comparison with sterol taphonomy in other microbial mats}

The results from the Lake 2 mat differ significantly from the results of a previous study on a microbial mat profile in another lake in Kiritimati (Lake 22; Shen et al., 2018a). Sterol concentrations from the topmost layers are similar in both mats $\left(10^{2} \mu \mathrm{g} / \mathrm{g} \mathrm{C}_{\text {org }}\right.$ range), but the Lake 22 mat showed no systematic decrease in sterols with depth. Such entirely different behaviour of sterols in these two lakes raises questions about potential mechanisms causing the observed variation.

One explanation for the differences between the Lake 2 and 22 mats could be variations in salinity. In 2011, the salinity of Lake 22 (Shen et al., 2018a) was $250 \%$, whereas Lake 2 showed $125 \%$. High salinity may reduce microbial cell growth and reproduction, and limit the metabolism of microorganisms. The resulting decrease in bacterial activity would affect the biodegradation rates of organic compounds (Abed et al., 2006). Several studies reported that the degradation rates of hydrocarbons significantly decrease as salinity increases (microbial mat from Saudi Arabia, Abed et al., 2006; water and tar samples from Great Salt Lake, Ward and Brock, 1978). On the other hand, lower salinity supports the proliferation of a more diverse microbial community (Bolhuis et al., 2014), thus possibly enhancing OM biodegradation. As a consequence, conditions for mat-forming microorganisms would be more favourable in Lake 2 as compared to the extremely hypersaline Lake 22, thus accelerating the biodegradation rates of organic molecules, including sterols. Another possible reason might be decreased precipitation resulting in the decline of water depth. A major drought period prevailed in Kiritimati from 2002 to 2011, as a result of a very strong La Niña dry event. Due to reduced rainfall, the water level of the lakes in Kiritimati generally dropped, so that, in some areas, parts of the lake bottoms became subaerially exposed. The Lake 22 microbial mat was collected at the margin of the lake (Figure 3.2f; water depth c. $0.2 \mathrm{~m}$; Shen et al., 2018a). Therefore, mats from this shallow sampling site may have suffered from heavy evaporation due to such major drought events. As pointed out by Shen et al. (2018a), the Lake 
22 mat shows an irregular top layer of $\mathrm{V}$-shaped fractures, which are general characteristic features of evaporitic settings, thus further demonstrating the repeated occurrence of dry periods in the region. On the other hand, the Lake 2 mat was collected in the lake centre (water depth c. $4 \mathrm{~m}$ ) which is clearly less prone to subaerial exposure. These interpretations are further supported by other studies that highlighted how environmental conditions such as water depth and salinity may have a significant influence on the microbial composition of microbial mats (Pagès et al., 2014). In addition to these environmental conditions, the differences of stanol/stenol ratios between the two lakes are noteworthy. Much higher ratios were observed in Lake 22 mat (Shen et al., 2018a), indicating a much more intense anaerobic microbial transformation (yet no degradation) as compared to the Lake 2 mat (Figure 3.6). Whereas sterols in Lake 22 mat experienced major microbial transformation (stenols $\Rightarrow$ stanols $=>$ sterenes), sterols in Lake 2 apparently suffered from major degradation that suppressed the primary ecological signal. The contrasting distributions observed for the Kiritimati mats studied also suggest that sterols have a higher preservation potential in microbial mats under stronger salinities and/or more desiccated conditions, such as those of Lake 22. Our finding of such significant differences in two adjacent mat settings on the same island calls for great caution when studying sterols in microbialites or in modern microbial mats and making generalizations for the fossil record. Sterol preservation within microbial mats is a complex process that may be strongly influenced by environmental parameters. Therefore, palaeoenvironments must be thoroughly constrained if the presence, or absence, of these compounds is interpreted in the study of ancient deposits.

\subsection{Conclusion}

The preservation of primary eukaryotic sterols and their progressive alteration was studied in a c. 1500 years old microbial mat from the hypersaline Lake 2 on Kiritimati. High $\delta^{13} \mathrm{C}$ values of $\mathrm{C}_{31}$-sterols and fatty acids suggest an autochthonous origin for these lipids. Total sterols decreased immediately below the uppermost layer, suggesting a major degradation of these compounds within the mat. A different pattern was observed for unusual, isotopically heavy $\mathrm{C}_{31}$-sterols ( $4 \alpha$-methylgorgosterol and $4 \alpha$-methylgorgostanol; $\delta^{13} \mathrm{C}=-7.2 \%$ ), which showed increasing abundances in the deeper mat layers as compared to the conventional $\mathrm{C}_{27}-\mathrm{C}_{29}$ sterols. These $\mathrm{C}_{31}$ sterols may have partly derived from resting cells of dinoflagellates, or their unusual side-chain might hamper degradation, which may have enhanced the resistance of these sterols against degradation. No significant 'trapping' of sterols into the mineral lattice occurred in this mat. Likewise, steroids were not sequestered into insoluble organic matter (as 
opposed to hopanoids). It is therefore suggested that the studied mat might have formed an effective filter against the preservation of sterols in the sedimentary record. The results from this microbial mat, therefore, support the hypothesis of a 'mat-seal effect' describing the degradation of eukaryote-derived lipids in benthic microbial mats. Our results are markedly different from those recently obtained from another mat from Kiritimati Lake 22, where sterols showed no systematic decrease with depth, suggesting that the preservation of sterol carbon skeletons in that microbial mat did not suffer from a mat-seal effect. In that lake, an even higher salinity or temporal subaerial exposure may have hampered microbial metabolism and instead promoted sterol transformation rather than degradation. The combined data show that sterol taphonomy may strongly vary between different mat systems, and even contrasting sterol degradation patterns may be expected in response to environmental conditions.

\section{Acknowledgements}

We thank Prof. Dr. Gernot Arp and Dr. Martin Blumenberg for helpful information and constructivecomments. Dr. Andreas Reimer is acknowledged for hydrochemical measurements. We are grateful that Dr. Jens. Dyckmans analyse the compound-specific carbon isotopes. Dr. Pablo Suarez-Gonzalez acknowledges funding by a postdoctoralresearch fellowship of the Alexander von Humboldt Foundation. Wolfgang Dröse, Birgit Röring and Dorothea Hause-Reitner are kindly acknowledged for laboratory assistance. This research has received funding from the German Research Foundation (DFG, Project Re 665/18-2 and Research Unit 571 “Geobiology of Organo- and Biofilms”). 


\section{References}

Abed, R. M. M., Al-Thukair, A., and de Beer, D. (2006). Bacterial diversity of a cyanobacterial mat degrading petroleum compounds at elevated salinities and temperatures. FEMS Microbiology Ecology, 57, 290-301.

Amo, M., Suzuki, N., Kawamura, H., Yamaguchi, A., Takano, Y., and Horiguchi, T. (2010). Sterol composition of dinoflagellates: Different abundance and composition in heterotrophic species and resting cysts. Geochemical Journal, 44, 225-231.

Anbar, A. D. and Knoll, A. H. (2002). Proterozoic ocean chemistry and evolution: A bioinorganic bridge? Science, 297, 1137-1142.

Arp, G., Helms, G., Karlinska, K., Schumann, G., Reimer, A., Reitner, J., and Trichet, J. (2012). Photosynthesis versus Exopolymer Degradation in the Formation of Microbialites on the Atoll of Kiritimati, Republic of Kiribati, Central Pacific. Geomicrobiology Journal, $29,29-65$.

Arp, G., Reimer, A., and Reitner, J. (1999). Calcification in cyanobacterial biofilms of alkaline salt lakes. European Journal of Phycology, 34, 393-403.

Atwood, A. R., Volkman, J. K., and Sachs, J. P. (2014). Characterization of unusual sterols and long chain diols, triols, keto-ols and n-alkenols in El Junco Lake, Galápagos. Organic Geochemistry, 66, 80-89.

Birgel, D., Thiel, V., Hinrichs, K.-U., Elvert, M., Campbell, K. A., Reitner, J., Farmer, J. D., and Peckmann, J. (2006). Lipid biomarker patterns of methane-seep microbialites from the Mesozoic convergent margin of California. Organic Geochemistry, 37, 1289-1302.

Birk, J. J., Dippold, M., Wiesenberg, G. L. B., and Glaser, B. (2012). Combined quantification of faecal sterols, stanols, stanones and bile acids in soils and terrestrial sediments by gas chromatography-mass spectrometry. Journal of chromatography. A, $1242,1-10$.

Blumenberg, M., Thiel, V., and Reitner, J. (2015). Organic matter preservation in the carbonate matrix of a recent microbial mat - Is there a 'mat seal effect'? Organic Geochemistry, 87, 25-34.

Blumenberg, M., Thiel, V., Riegel, W., Kah, L. C., and Reitner, J. (2012). Biomarkers of black shales formed by microbial mats, Late Mesoproterozoic $(1.1 \mathrm{Ga})$ Taoudeni Basin, Mauritania. Precambrian Research, 196-197, 113-127.

Bolhuis, H., Cretoiu, M. S., and Stal, L. J. (2014). Molecular ecology of microbial mats. FEMS Microbiology Ecology, 90, 335-350.

Brassell, S. C. and Eglinton, G. (1983). Steroids and triterpenoids in deep sea sediments as environmental and diagenetic indicators. Advances in Organic Geochemistry 1981, 684697.

Brocks, J. J., Jarrett, A. J. M., Sirantoine, E., Hallmann, C., Hoshino, Y., and Liyanage, T. (2017). The rise of algae in Cryogenian oceans and the emergence of animals. Nature, 548, $578-581$. 
Brocks, J. J. and Summons, R. E. (2004). Sedimentary Hydrocarbons, Biomarkers for Early Life, Treatise on Geochemistry, 8, 63-115.

Bühring, S. I., Smittenberg, R. H., Sachse, D., Lipp, J. S., Golubic, S., Sachs, J. P., Hinrichs, K. U. and Summons, R. E. (2009). A hypersaline microbial mat from the Pacific Atoll Kiritimati: insights into composition and carbon fixation using biomarker analyses and a ${ }^{13}$ C-labeling approach. Geobiology, 7, 308-323.

Close, H. G., Bovee, R., and Pearson, A. (2011). Inverse carbon isotope patterns of lipids and kerogen record heterogeneous primary biomass. Geobiology, 9, 250-265.

Decho, A. W. (2011). Extracellular polymeric substances (EPS), Encyclopedia of Geobiology, 359-361.

Des Marais, D. J. (2003). Biogeochemistry of hypersaline microbial mats illustrates the dynamics of modern microbial ecosystems and the early evolution of the biosphere. The Biological bulletin, 204, 160-167.

Dupraz, C., Pamela Reid, R., Braissant, O., Decho, A. W., Norman, R. S., and Visscher, P. T. (2009). Processes of carbonate precipitation in modern microbial mats. Earth-Science Reviews, 96, 141-162.

Dutkiewicz, A., Volk, H., Ridley, J., and George, S. (2003). Biomarkers, brines, and oil in the Mesoproterozoic, Roper Superbasin, Australia. Geology, 31, 981-984.

Fowler, S. W. and Knauer, G. A. (1986). Role of large particles in the transport of elements and organic compounds through the oceanic water column. Progress in Oceanography, 16, $147-194$.

Gaskell, S. and Eglinton, G. (1976). Sterols of a contemporary lacustrine sediment. Geochimica et Cosmochimica Acta, 40, 1221-1228.

Gaskell, S. J. and Eglinton, G. (1975). Rapid hydrogenation of sterols in a contemporary lacustrine sediment. Nature, 254, 209-211.

Giner, J.-L., Faraldos, J. A., and Boyer, G. L. (2003). Novel sterols of the toxic dinoflagellate Karevia Brevis (Dinophyceae): a defensive function for unusual marine sterols? J Phycol, 39, 31-319.

Grimalt, J. O., de Wit, R., Teixidor, P., and Albaigés, J. (1992). Lipid biogeochemistry of Phormidium and Microcoleus mats. Organic Geochemistry, 19, 509-530.

Grotzinger, J. P. and Knoll, A. H. (1999). Stromatolites in Precambrian carbonates: evolutionary mileposts or environmental dipsticks? Annual review of earth and planetary sciences, 27, 313-358.

Houle, H. M., Lopez, C. B., and Leblond, J. D. (2018). Sterols of the Toxic Marine Dinoflagellate, Pyrodinium bahamense. The Journal of eukaryotic microbiology, 1-5, In Press.

Ionescu, D., Spitzer, S., Reimer, A., Schneider, D., Daniel, R., Reitner, J., de Beer, D., and Arp, G. (2015). Calcium dynamics in microbialite-forming exopolymer-rich mats on the atoll of Kiritimati, Republic of Kiribati, Central Pacific. Geobiology, 13, 170-180. 
Knoll, A. H., Summons, R. E., Waldbauer, J. R., and Zumberge, J. E. (2007). The Geological Succession of Primary Producers in the Oceans, in: Evolution of Primary Producers in the Sea, Elsevier, 133-163.

Logan, G. A., Hayes, J. M., Hieshima, G. B., and Summons, R. E. (1995). Terminal Proterozoic reorganization of biogeochemical cycles. Nature, 376, 53-56.

Mattern, G., Albrecht, P., and Ourisson, G. (1970). 4-Methyl-sterols and sterols in Messel Shale (Eocene). Chemical Communications, 1570-1571.

Nishimura, M. (1977). Origin of stanols in young lacustrine sediments. Nature, 270, 711-712.

O'Reilly, S. S., Mariotti, G., Winter, A. R., Newman, S. A., Matys, E. D., McDermott, F., Pruss, S. B., Bosak, T., Summons, R. E., and Klepac-Ceraj, V. (2017). Molecular biosignatures reveal common benthic microbial sources of organic matter in ooids and grapestones from Pigeon Cay, The Bahamas. Geobiology, 15, 112-130.

Otto, A. and Simpson, M. J. (2005). Degradation and Preservation of Vascular Plant-derived Biomarkers in Grassland and Forest Soils from Western Canada. Biogeochemistry, 74, 377-409.

Pagès, A., Grice, K., Ertefai, T., Skrzypek, G., Jahnert, R., and Greenwood, P. (2014). Organic geochemical studies of modern microbial mats from Shark Bay: Part I: Influence of depth and salinity on lipid biomarkers and their isotopic signatures. Geobiology, 12, 469-487.

Pawlowska, M. M., Butterfield, N. J., and Brocks, J. J. (2013). Lipid taphonomy in the Proterozoic and the effect of microbial mats on biomarker preservation. Geology, 41, 103106.

Peckmann, J. and Thiel, V. (2004). Carbon cycling at ancient methane-seeps. Chemical Geology, 205, 443-467.

Rampen, S. W., Abbas, B. A., Schouten, S., and Sinninghe Damsté, J. S. (2010). A comprehensive study of sterols in marine diatoms (Bacillariophyta): Implications for their use as tracers for diatom productivity. Limnol. Oceanogr., 55, 91-105.

Rampen, S. W., Schouten, S., Hopmans, E. C., Abbas, B., Noordeloos, A. A.M., van Bleijswijk, J. D.L., Geenevasen, J. A.J., and Sinninghe Damsté, J. S. (2009). Diatoms as a source for 4-desmethyl-23,24-dimethyl steroids in sediments and petroleum. Geochimica et Cosmochimica Acta, 73, 377-387.

Reitner, J. and Thiel, V. (Eds) (2011). Encoclopedia of Geobiology, Springer, 1-956.

Riding, R. (2011). The Nature of Stromatolites: 3,500 Million Years of History and a Century of Research, in: Advances in Stromatolite Geobiology, Reitner, J., Quéric, N.-V., Arp, G. (Eds.), Lecture Notes in Earth Sciences, Springer Berlin Heidelberg, Berlin, Heidelberg, $29-74$.

Robinson, N., Cranwell, P. A., Finlay, B. J., and Eglinton, G. (1984). Lipids of aquatic organisms as potential contributors to lacustrine sediments. Organic Geochemistry, 6, 143 152. 
Rosenfeld, R. S. and Hellman, L. (1971). Reduction and esterification of cholesterol and sitosterol by homogenates of feces. Journal of Lipid Research, 12, 192-197.

Saenger, C., Miller, M., Smittenberg, R. H., and Sachs, J. P. (2006). A physico-chemical survey of inland lakes and saline ponds: Christmas Island (Kiritimati) and Washington (Teraina) Islands, Republic of Kiribati. Saline systems, 2, 1-15.

Scherf, A.-K. and Rullkötter, J. (2009). Biogeochemistry of high salinity microbial mats Part 1: Lipid composition of microbial mats across intertidal flats of Abu Dhabi, United Arab Emirates. Organic Geochemistry, 40, 1018-1028.

Schneider, D., Arp, G., Reimer, A., Reitner, J., Daniel, R., and Balcazar, J. L. (2013). Phylogenetic Analysis of a Microbialite-Forming Microbial Mat from a Hypersaline Lake of the Kiritimati Atoll, Central Pacific. PLoS ONE, 8, e66662.

Schouten, S., Hartgers, W. A., Lopez, J. F., Grimalt, J. O., and Sinninghe Damsté, J. S. (2001). A molecular isotopic study of 13C-enriched organic matter in evaporitic deposits: recognition of $\mathrm{CO}_{2}$-limited ecosystems. Organic Geochemistry, 32, 277-286.

Shen, Y., Thiel, V., Duda, J.-P., and Reitner, J. (2018a). Tracing the fate of steroids through a hypersaline microbial mat (Kiritimati, Kiribati/Central Pacific). Geobiology, 16, 307-318.

Shen, Y., Suarez-Gonzalez, P., Thiel V., Blumenberg, M., Reitner, J. (2018b). Different modes of calcification control the preservation of organic matter in a recent microbial mat. AGU Fall Meeting, Washington, D.C., USA, 10-14 December 2018, B43H-2952.

Słowakiewicz, M., Whitaker, F., Thomas, L., Tucker, M. E., Zheng, Y., Gedl, P., and Pancost, R. D. (2016). Biogeochemistry of intertidal microbial mats from Qatar: New insights from organic matter characterization. Organic Geochemistry, 102, 14-29.

Smrzka, D., Zwicker, J., Kolonic, S., Birgel, D., Little, C. T.S., Marzouk, A. M., Chellai, E. H., Wagner, T., and Peckmann, J. (2017). Methane seepage in a Cretaceous greenhouse world recorded by an unusual carbonate deposit from the Tarfaya Basin, Morocco. Depositional Rec, 3, 4-37.

Summons, R. E., Bird, L. R., Gillespie, A. L., Pruss, S. B., Roberts, M., and Sessions, A. L. (2013). Lipid biomarkers in ooids from different locations and ages: evidence for a common bacterial flora. Geobiology, 11, 420-436.

Summons, R. E., Powell, T. G., and Boreham, C. J. (1988). Petroleum geology and geochemistry of the middle Proterozoic McArthur Basin, Northern Australia: III. Composition of extractable hydrocarbons. Geochimica et Cosmochimica Acta, 52, 17471763.

Thiel, V., Peckmann, J., Richnow, H. H., Luth, U., Reitner, J., and Michaelis, W. (2001). Molecular signals for anaerobic methane oxidation in Black Sea seep carbonates and a microbial mat. Marine Chemistry, 73, 97-112.

Thiel, V., Peckmann, J., Seifert, R., Wehrung, P., Reitner, J., and Michaelis, W. (1999). Highly isotopically depleted isoprenoids: Molecular markers for ancient methane venting. Geochimica et Cosmochimica Acta, 63, 3959-3966. 
Trichet, J., Défarge, C., Tribble, J., Tribble, G., and Sansone, F. (2001). Christmas Island lagoonal lakes, models for the deposition of carbonate-evaporite-organic laminated sediments. Sedimentary Geology, 140, 177-189.

Valencia, M. (1977). Christmas Island (Pacific ocean): Reconnaissance geologic observations. Atoll Research Bulletin, 197, 1-19.

van Bergen, P. F., Bull, I. D., Poulton, P. R., and Evershed, R. P. (1997). Organic geochemical studies of soils from the Rothamsted classical experiments-I. Total lipid extracts, solvent insoluble residues and humic acids from Broadbalk Wilderness. Organic Geochemistry, 26, 117-135.

van Gemerden, H. (1993). Microbial mats: A joint venture. Marine Geology, 113, 3-25.

Volkman, J. K. (1986). A review of sterol markers for marine and terrigenous organic matter. Organic Geochemistry, 9, 83-99.

Volkman, J. K. (2003). Sterols in microorganisms. Appl Microbiol Biotechnol, 60, 495-506.

Volkman, J. K. (2005). Sterols and other triterpenoids: Source specificity and evolution of biosynthetic pathways. Organic Geochemistry, 36, 139-159.

Wakeham, S. G. (1989). Reduction of stenols to stanols in particulate matter at oxic-anoxic boundaries in sea water. Nature, 342, 787-790.

Walter, M. R. (1976). Stromatolites, Developments in Sedimentology, 20, Elsevier Scientific Pub. Co, Amsterdam, New York.

Ward, D. M. and Brock, T. D. (1978). Hydrocarbon biodegradation in hypersaline environments. Applied and Environmental Microbiology, 35, 353-359.

Wingender, J., Neu, T. R., and Flemming, H.-C. (Eds) (1999). Microbial Extracellular Polymeric Substances; Characterization, Structure, and Function. Springer, Berlin, Heidelberg, Germany, 258 p. 
-Chapter 4-

\title{
Different modes of calcification control the preservation of organic matter in a recent microbial mat
}

\author{
(in preparation) \\ Yan Shen, Pablo Suarez-Gonzalez, Volker Thiel, Martin Blumenberg, Joachim Reitner
}

\begin{abstract}
Microbial mats probably represented the earliest complex ecosystems on Earth since fossil mineralized examples (i.e., microbialites) are as old as the Archean $(\sim 3.5 \mathrm{Ga})$, and some contain putative remains of organic matter (OM). However, the processes and pathways of microbial mat mineralization and of OM preservation within them are still poorly understood. Here, we analysed lipid biomarkers, and performed petrography and histology of a recent ( 1500 years) calcifying mat from a hypersaline lake in Kiritimati, Central Pacific. Our results reveal two major phases of microbial mat development, separated by a distinctive, laterally continuous thin mineral crust. Two distinct calcification modes are observed: one characteristic of the main microbialite laminae that are observed in both accretion phases, and another observed only in the thin mineral crust. Interestingly, the original OM is preserved differently in each precipitation mode. In the main microbialite laminae, the minerals observed primarily consist of calcium carbonate (aragonite), occurring either as irregular micritic crystals or as subspherical particles. These minerals are interpreted as precipitated in association with the gradual degradation of extracellular polymeric substances (EPS), which initially inhibit carbonate precipitation. Such gradual degradation of OM through time is reflected by a decline in total organic carbon and bacteria-derived hopanoids and fatty acids downwards in the mat laminae. In contrast, the thin mineral crust at the boundary between both growth phases formed during an interruption in the microbial mat accretion. It is composed of a $\mu \mathrm{m}$-scale superposition of radial-fibrous aragonite botryoids that entomb very abundant filamentous microbes and diatoms. This suggests that a significant change occurred during the hiatus: the mat surface was covered by a thin biofilm of a different biotic composition. This biofilm was completely calcified in different episodes of a relatively fast


collapse of the EPS inhibitory function, probably controlled by changes in the hydrochemically conditions, which is evident from the depleted $\delta^{13} \mathrm{C}$ signatures for lipid biomarkers observed within the thin mineral crust. This event-like mode of calcification caused a fast and efficient inclusion of lipid biomarkers, as reflected by a remarkable increase in the abundances of fatty acids and, to a lesser extent, hopanoids. These results suggest that episodic environmental changes could have induced a rapid entombment of OM in microbial mats and its enhanced preservation within distinctive mineral precipitates. Such rapidly formed precipitates may have preserved OM better than the average mineralization mode commonly observed in microbial mats, and thus they represent excellent targets for the search of authentic OM in the ancient microbialites.

Keywords: taphonomy, lipid biomarker, microfacies, mineralization, microbialites

\subsection{Introduction}

Microbial mats probably represented the earliest complex ecosystems on Earth. They are mmto $\mathrm{cm}$-thick vertically laminated organosedimentary structures, which may occur in many different environments including coastal lagoons, marine intertidal zones, hypersaline and alkaline lakes, hot springs and freshwater rivers (Arp et al., 1998; Bolhuis et al., 2013; Freytet and Plet, 1996; Ionescu et al., 2015; Scherf and Rullkötter, 2009; Shiea et al., 1991; van der Meer, 2002; Słowakiewicz et al., 2016). Microbial mats consist of several specialized biotic consortia (van Gemerden, 1993; Dupraz and Visscher, 2005), and each layer contains different microorganisms with distinct metabolic activities, e.g. photoautotrophs (cyanobacteria), anoxygenic phototrophs (purple and green bacteria), aerobic heterotrophic bacteria, fermenters, anaerobic heterotrophs (SRB, sulfate-reducing bacteria) and sulphide oxidizing bacteria (SOB). Microbial mats are efficient in element cycling via the metabolic processes of these microbial communities, e.g. cyanobacteria couple light energy to $\mathrm{CO}_{2}$ fixation, leading to the accumulation of biomass, which is later oxidized and/or recycled by SRB and SOB. Under certain conditions, part of the microbial mat biomass might be transformed and preserved within mineral precipitates (commonly carbonate) that lead to the fossilization of the mat (i.e., microbialite).

In general, two factors (mediated by microbial activity and physicochemical features) control carbonate precipitation within microbial mats: extracellular polymeric substances (EPS) and saturation index (determined by $\mathrm{pH}$ and $\mathrm{Ca}^{2+}$, Arp et al., 1999a; Arp et al., 2001; 
Dupraz and Visscher, 2005; Reitner, 1993). EPS are secreted by most microbes, and mainly comprise polysaccharides, proteins, nucleic acids, lipids and humic substances (Nielsen et al., 1997). In most cases, EPS serve as protection against multiple stress conditions, such as desiccation, nutrient shortages and UV exposure. Due to their functional groups (e.g. COO-), EPS are able to bind divalent free cations (e.g. $\mathrm{Ca}^{2+}$ and $\mathrm{Mg}^{2+}$ ), inhibiting mineral precipitation by depleting the positive ions from the surrounding environment. Therefore, microbial carbonate formation is controlled by the inhibitory function of acidic EPS, and carbonate precipitates are formed when EPS release the cations, as they are gradually degraded during the evolution of the mat (Arp et al., 2012; Arp et al., 2003; Dupraz et al., 2011). This form of mineral precipitation influenced by the presence of organic matrices is often termed organomineralization, and it entails that EPS provide the location of mineral nucleation within microbial mats (Dupraz et al., 2009). Calcification is also related to supersaturation of calcium carbonate minerals. When the critical level of supersaturation of $\mathrm{CaCO}_{3}$ mineral is surpassed, combined with the release of divalent cations such as $\mathrm{Ca}^{2+}$, carbonate nucleates and grows, which is more likely to occur in deeper parts of the mat, where EPS are more degraded (Arp et al., 1998).

The term "microbialite" was introduced by Burne and Moore (1987) as a definition for mineral deposits which result from microbially-mediated mineral precipitation. They have been formed throughout the geological record, the oldest microbialites being $\sim 3.5 \mathrm{Ga}$ (Pilbara Craton, Western Australia; Allwood et al., 2006; Hofmann et al., 1999), whereas the younger ones occurs in various modern environmental conditions (Awramik and Vanyo, 1986; Couradeau et al., 2012). Microbialites are mainly composed of carbonate (e.g. stromatolites, laminated microbialites) combined with other types of minerals such as phosphate and silicate, and putative remains of the original organic matter (OM) have been found within some of them. For instance, Thiel et al. (1999) reported organic compounds preserved in the carbonate matrix of ancient cold seep microbialites; nanoscale detection of organic signatures in carbonate microbialites from a soda lake (Benzerara et al., 2006); these OM was also sequestrated into carbonate-silicate microbialites from Hawaiian basaltic sea caves (Léveillé et al., 2000). In the last decades, several hypotheses of calcification mechanisms have been proposed for modern hypersaline mats, e.g. both photosynthesis and EPS degradation promote the formation of microbialites in Kiritimati lake (Arp et al., 2012); succession of microbial community leading to laminae of stromatolitic knobs in Bahamas lake (Dupraz et al., 2013). 
However, the exact processes that lead to mineralization of a microbial mat, especially the preservation of $\mathrm{OM}$ in the resulting microbialites remains incompletely understood.

Microbial mats have been proposed to be a predominant life form in Proterozoic marine environments (Grotzinger and Knoll, 1999; Riding, 2011; Walter, 1976). Recent microbial mats are considered potential analogues of ancient microbialites because they resemble many fossil microbialites that persisting morphological similarities, and rapid cycling of major elements occurs within the mats on very small $(\mathrm{mm}-\mu \mathrm{m})$ scales. Therefore, investigation on recent microbial mats is of great importance for a better understanding of fossil microbialites, e.g. unravelling the mineralization of the mat as well as the associated preservation of OM in the ancient microbialites.

Kiritimati (Central Pacific) is the largest coral atoll in the world, covering surface area c. $360 \mathrm{~km}^{2}$. It is well suited for testing taphonomy of OM in microbial mats, because the atoll contains c. 500 brackish to hypersaline lakes hosting plenty of mats, which show features of great thickness, clear lamination and ongoing mineral precipitation (i.e., microbialite formation). Taphonomy of OM has been already investigated through lipid biomarkers in several of these mats (Blumenberg et al., 2015; Shen et al., 2018). However, the detailed preservation pathways of bacteria-derived OM in different lipid pools have not been evaluated in any of the Kiritimati mats so far.

This work aims to shed light on the relationship between the modes of mineral precipitation within microbial mats and the preservation of $\mathrm{OM}$ therein, using a recent $(\sim 1500$ years BP) calcifying mat from a hypersaline lake in Kiritimati, and combining lipid biomarker analyses, with a detailed petrographic and histologic investigation of the different mat horizons. This dual (organogeochemical and geomicrobiological) approach allows to better elucidate the distinctive mineralization processes controlling the preservation of $\mathrm{OM}$ within the resulting carbonate precipitates.

\subsection{Materials and methods}

\subsubsection{Site description and sample collection}

Kiritimati (formerly Christmas Island) is the world's largest coral atoll, with the surface area c. $360 \mathrm{~km}^{2}$. It is located in the Central Pacific and close to the Equator $\left(1^{\circ} 55^{\prime} \mathrm{N}, 157^{\circ} 25^{\prime} \mathrm{W}\right)$. The island harbours approximately 500 lakes with salinities ranging from brackish to 
hypersaline conditions, in many of which, well-developed microbial mats occur. In general, Kiritimati has an arid climate and is mostly controlled by the El Niño-Southern Oscillation (ENSO). Recharge of lakes occurs as a result of heavy rains during El Niño wet events, leading to a decrease in lake salinities. During La Niña dry events, reduced precipitation and higher evaporation induce an increase in lake salinities. More detailed information about the site description can be found elsewhere (Arp et al., 2012; Saenger et al., 2006).

Sampling was carried out during a 2-week expedition on the atoll of Kiritimati in March 2011 (Figure 4.1). The microbial mat studied in this work is $10 \mathrm{~cm}$ thick and it was collected from the centre of Lake 2 at water depth c. $4 \mathrm{~m}$ (Blumenberg et al., 2015). The salinity of Lake 2 was 97\%o in 2002 and 125\% in 2011 (own data, unpublished). Blumenberg et al. (2015) divided the mat in five layers based on the macroscopic appearance. In this work, the same layer divisions were exercised as Blumenberg et al. (2015). Markedly, we additionally analysed a thin but distinctive mineral crust, occurring just below layer 2 (Figure 4.2c), which has not been analysed in the previous study (corresponding to our layer 3, Figures 4.1, 4.2). Therefore, six layers in total, each representing c. $1-2 \mathrm{~cm}$ thick (except layer $3 \sim 0.15 \mathrm{~cm}$ ) were investigated for this work.

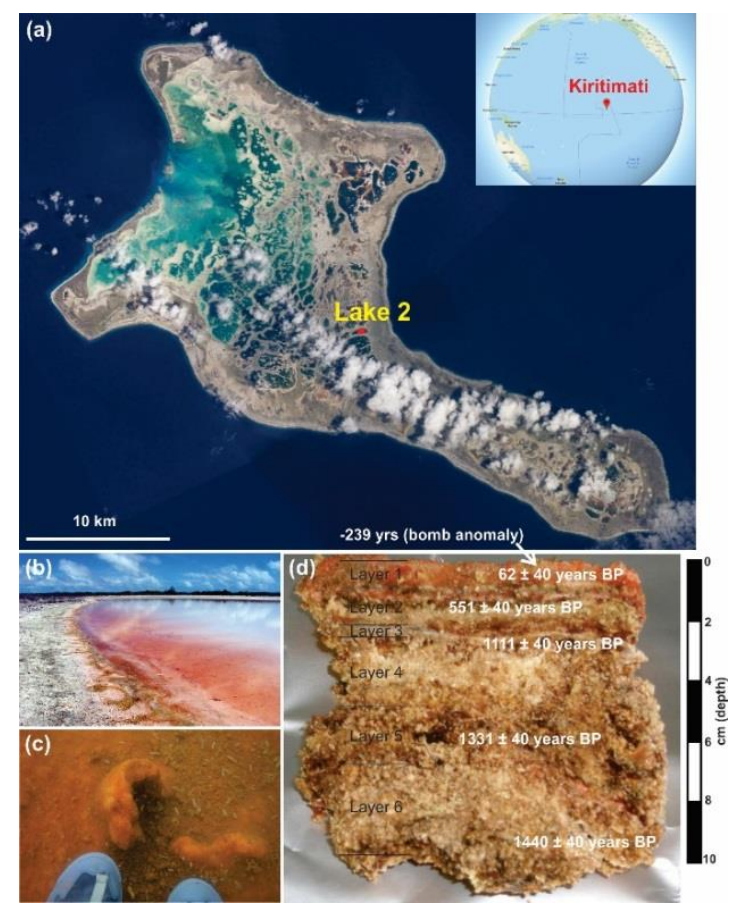

Figure 4.1 (a) General location of Kiritimati atoll in the Pacific Ocean and its satellite image, showing a reticulate distribution pattern of the lakes. The red dot indicates the sampling site of this study, Lake 2; (b) View of Lake 2 shore; (c) Photograph showing active microbial mats and whitish fish coprolites in Lake 2; (d) Microbial mat sample from Lake 2 studied in this work. ${ }^{14} \mathrm{C}$ dates of carbonate particles, measured by Blumenberg et al. (2015). 


\subsubsection{Preparation of histological thin sections}

For the preparation of histological thin sections, samples were dehydrated with a graded ethanol series. Afterwards, mat samples were embedded in LR White resin (medium grade, London Resin Company Ltd., Reading, UK), following the manufacturer's instructions. The embedded samples were cut with a microtome saw (Leica SP1600) to a thickness of c. 100 $\mu \mathrm{m}$, mounted on glass slides using Biomount mounting medium (Electron Microscopy Sciences, Hatfield, PA). Thin sections were studied under petrographic (Zeiss Axiolab) and fluorescence (Zeiss Imager. Z1) microscopes.
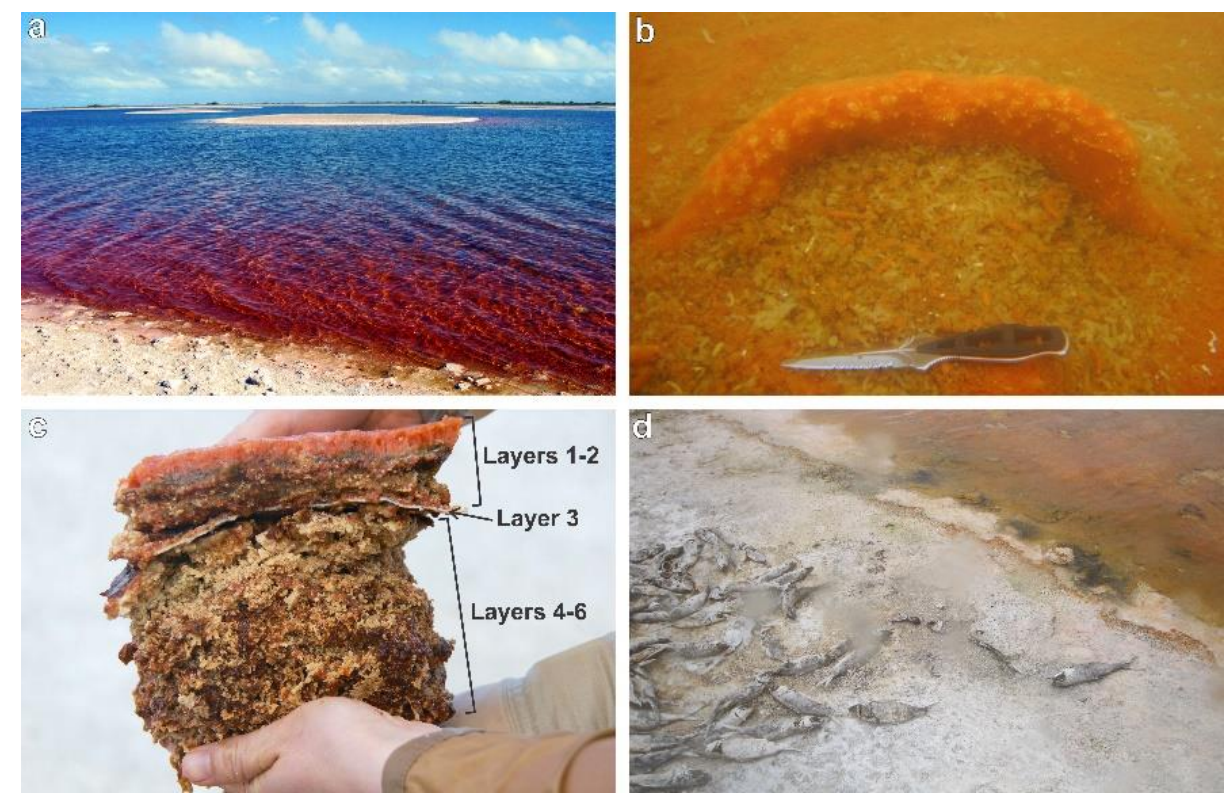

Figure 4.2 Field images. (a) General view of hypersaline Lake 2 in Kiritimati; (b) Underwater photograph showing an example of fresh, currently-active, orange-coloured microbial mat at the bottom of the lake; (c) The microbial mat sampled for this study, with clear colour-zonation; note the whitish mineral crust (Layer 3) separating the upper fresher layer from the older, more mineralized layers; (d) Lake shore showing dead fish; modified after Shen et al., 2019).

\subsubsection{Preparation for the electron microscope}

To observe the mineral fraction of the microbial mat under a field-emission scanning electron microscope (FE-SEM), the organic matter of the samples was removed through oxidation with $\mathrm{NaOCl}$ (Mikutta et al., 2005). Each sample from individual mat layer was immersed in $6 \% \mathrm{NaOCl}$, changing the solution every $12 \mathrm{~h}$ for several days, until no traces of organic matter were visible. The remaining mineral particles were washed with distilled $\mathrm{H}_{2} \mathrm{O}$ until $\mathrm{pH}$ was neutral, and then dried. Mineral particles were mounted on SEM sample holders and sputtered with Pt (14.1 nm for $5 \mathrm{~min}$ ) and then observed in a FE-SEM (Leica EM QSG100) combined with an INCA X-act EDX (Oxford Instruments). 


\subsubsection{Bulk analysis}

Homogenized aliquots of the freeze-dried samples, including the original mat samples and decalcified extraction residues, were subjected to C/N/S analysis, using a Hekatech EA 3000 CNS analyser and LECO RC 612 as described elsewhere (Shen et al., 2018).

\subsubsection{Extraction and derivatization}

Aliquots of the freeze-dried samples (5-20 g) were homogenized (not powdered) and extracted by $4 \times 50 \mathrm{ml}$ dichloromethane/methanol $(3: 1 ; \mathrm{V} / \mathrm{V})(10 \mathrm{~min}$ ultrasonication, respectively) to get freely extractable lipids. The resulting extraction residues was decalcified using $37 \% \mathrm{HCl}$, and was again extracted as described above to obtain the carbonate-bound lipids. The remaining extraction residues were freeze dried for the analysis of bulk $\mathrm{C}_{\text {org }}$ and pyrolysis.

To make carboxylic acids GC-amenable, a mixture of trimethylchlorosilane (TMCS)/MeOH $(1: 9, \mathrm{~V}: \mathrm{V})$ was added to a $5 \%$ aliquots of the lipid extracts (both freely extractable and carbonate-bound lipids, at $80^{\circ} \mathrm{C}$ for $\left.60 \mathrm{~min}\right)$. The resulting carboxylic acid methyl esters and the neutral lipids (including $n$-alkanes and hopanoid hydrocarbons) were extracted from the reaction mixture by vigorous shaking with $3 \times 1 \mathrm{ml} n$-hexane. The extracts were combined and evaporated to near-dryness under a gentle $\mathrm{N}_{2}$ flow, re-dissolved in $n$ hexane, and analysed by gas chromatography-mass spectrometry (GC-MS).

To make alcohols (including sterols and hopanols) GC-amenable, all aliquots of lipid fractions were silylated using BSTFA (N,O-bis(trimethylsilyl)trifluoroacetamide) containing $5 \%(\mathrm{~V} / \mathrm{V})$ trimethylchlorosilane (TMCS) as a catalyser (heated at $70^{\circ} \mathrm{C}$ for $60 \mathrm{~min}$ ). The resulting trimethylsilyl (TMS-) derivatives were dried, and re-dissolved in $n$-hexane, and analysed by gas chromatography-mass spectrometry (GC-MS).

\subsubsection{GC-MS}

GC-MS analyses were conducted using a Thermo Fisher Trace 1310 GC coupled to a Thermo Fisher Quantum XLS Ultra MS as described elsewhere (Shen et al., 2018). n-eicosane-D42 was used as an internal standard for quantification. 


\subsubsection{Pyrolysis-gas chromatography-mass spectrometry (Py-GC-MS)}

Aliquots of the decalcified extraction residues were pyrolysed on a fast-heating Pt-filament using a Pyrola 2000 pyrolysis device (Pyrolab SB) combined with a Varian CP3800 GC and a Varian 1200L MS as described elsewhere (Shen et al., 2018).

\subsubsection{Compound-specific stable carbon isotopes (GC-C-IRMS)}

Compound-specific stable carbon isotope ratios were measured for microbial lipids (i.e., FAs and hopanoids) and hydrocarbons as well as sterols in both freely extractable and carbonatebound lipid fractions in the studied microbial mat. Analyses were conducted using a Thermo Scientific Trace gas chromatograph (GC) coupled to a Delta Plus isotope ratio mass spectrometer (IRMS) as described elsewhere (Shen et al., 2019).

\subsubsection{Bulk stable isotope analysis}

Bulk carbonate samples for carbon stable isotope measurements were conducted in the different layers of the mat profile. The preparation of carbonate samples was finished after removal of OM (Mikutta et al., 2005; see 4.2.3 section), and the samples were collected in two separate parts based on the microscopical observation from the individual mat layers: fine-grained particles and spherical ooids. Carbonate powders were heated at $70^{\circ} \mathrm{C}$ and reacted with c. $105 \%$ oversaturated phosphoric acid. A Thermo Kiel IV carbonate device connected to a Finnigan Delta plus masspectrometer were used for the isotope measurements. All values were reported in per mil relative to $\mathrm{V}-\mathrm{PDB}$, which were calibrated by using $\mathrm{CO}_{2}$ gas of known isotopic composition against NBS $19 . \mathrm{CO}_{2}$ were analyzed with dual-inlet mode in masspectrometer. Reproducibility of measurement conditions has been checked by replicate analysis of laboratory standards, and one measurement consists of 8 cycles to control the standard deviation $(< \pm 0.05)$. The stable isotope measurements were carried out at the laboratory of Andreas Pack, University of Göttingen.

\subsection{Results}

\subsubsection{Description of mat layers at macro- and micro-scale}

The studied microbial mat has a thickness of $\mathrm{c} .10 \mathrm{~cm}$ and it is subdivided in two main parts based on their macroscopic aspects: a) the upper two layers (1-2, c. $3 \mathrm{~cm}$ thick, Figures 4.14.3) have a cohesive appearance, sticking together when handled, due to abundant and relatively fresh organic material (i.e., EPS), which shows bright orange, green and brown 
colours with transparent or whitish mineral particles therein (Figures 4.2c, $\underline{4.3}$ ); b) the lower three layers (4-6, c. $7 \mathrm{~cm}$ thick, Figures 4.1-4.3) are more friable, having a crumbly appearance, due to the rarer and poorly preserved EPS between more abundant mineral particles, producing brown and beige colours (Figures $4.2 \mathrm{c}, \underline{4.3}$ ). The ${ }^{14} \mathrm{C}$ ages of the mat (Blumenberg et al., 2015) show that its upper (and thinner) part was formed approximately in the last 1000 years $(62 \pm 40$ years BP for layer 1, 551 \pm 40 years BP for layer 2 and $1111 \pm 40$ years BP for layer 3; Figure 4.1d) whereas the lower (and thicker) part was formed approximately in the previous 330 years $(1331 \pm 40$ years BP for layer 5 and $1440 \pm 40$ years BP for layer 6; Figure 4.1d).

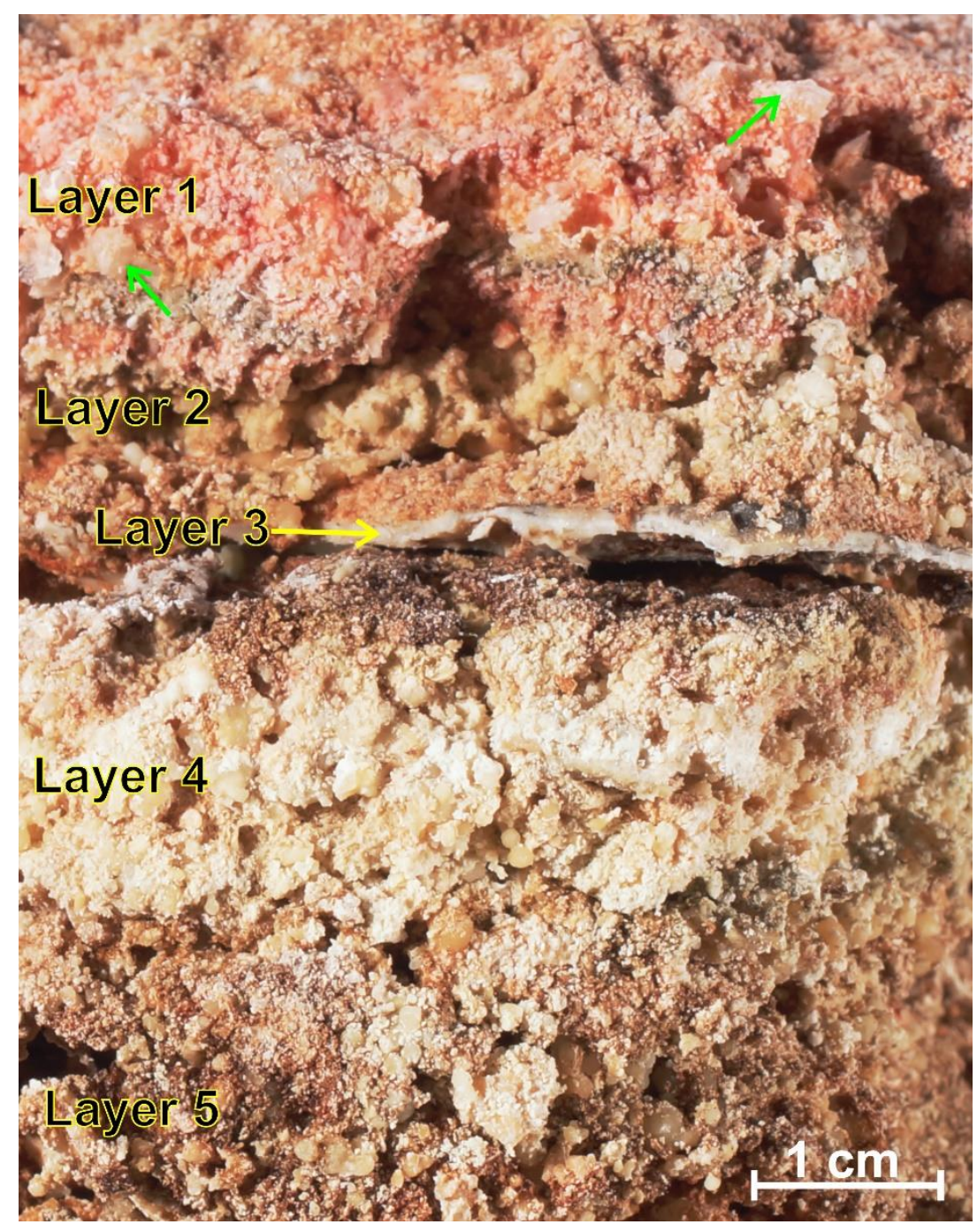

Figure 4.3 Close-up picture of frozen microbial mat sample studied in this work (compare with Figure 4.1). Green arrows point to transparent gypsum crystals, which occur only in the uppermost layer. Note common beige, irregular to subspherical, carbonate particles, more abundant downwards in the mat. Yellow arrow points to the whitish mineral crust that forms Layer 3, and which separates the younger upper part of the mat from the lower older layers. 
The mineral particles observed in the studied mat have mainly a calcium carbonate (aragonite) composition, with local idiomorphic calcium sulphate (gypsum) crystals occurring only at the uppermost part of layer 1 (Figures $4.3, \underline{4.4 a)}$. Carbonate precipitates occur either as irregular micritic particles with a micropeloidal internal texture (Figures 4.4b-c, $\underline{4.6 \mathrm{c}-\mathrm{d}}$ ) or as subspherical particles, commonly with a crystalline fibrous-radial internal structure (Figures $\underline{4.4 \mathrm{a}}, \underline{\mathrm{d}-\mathrm{f}}, \underline{4.6 \mathrm{a}-\mathrm{b}}$ ); cf. 'spherulites' of (Arp et al., 2012). In general, these carbonate precipitates are larger and more abundant downwards in the mat, and they tend to coalesce with each other forming complex aggregates of particles, which become larger in the lowermost layers of the mat (Figures 4.4e-f). This composition and distribution of mineral precipitates is consistent with that observed in other microbial mats from Kiritimati (Arp et al., 2012; Défarge et al., 1996; Trichet et al., 2001). The exception is layer 3, a very thin (1-2 $\mathrm{mm}$ ) but laterally very continuous carbonate crust that separates the younger and older parts of the mat ( $\underline{\text { Figures } 4.3}, \underline{4.5})$, and which shows features not previously described in Kiritimati microbial mats. With the naked eye, this crust shows white-beige colours with darker areas, and in general, it has a flat bottom and domed top (Figures 4.5a-b). Microscope observations show that the crust is composed of several superposed laminae of botryoidal carbonate with a fibrous-radial internal texture, formed by long aragonite needles (Figures 4.5c-e). These aragonite botryoids include abundant large pores filled by residual organic matter (i.e. EPS, Figures $4.5 \mathrm{c}, \mathrm{f}-\mathrm{g}$ ), which generate the darker areas observed macroscopically within the crust (Figure 4.5b). In addition, moulds of filamentous microbes and diatoms are ubiquitous throughout the crust, enclosed within the fibrous crystalline structure of the botryoids (Figures $\underline{4.5 \mathrm{e}, \mathrm{h}}$ ). These moulds are either empty (preserved as porosity) or filled by carbonate with only local preservation of the original EPS (Figure 4.5h). Diatom moulds also occur locally within mineral particles of the older layers (4-6), but not as abundant as in the crust of layer 3 . Within this crust, foraminifera have also locally been observed (Figure 4.5f). 

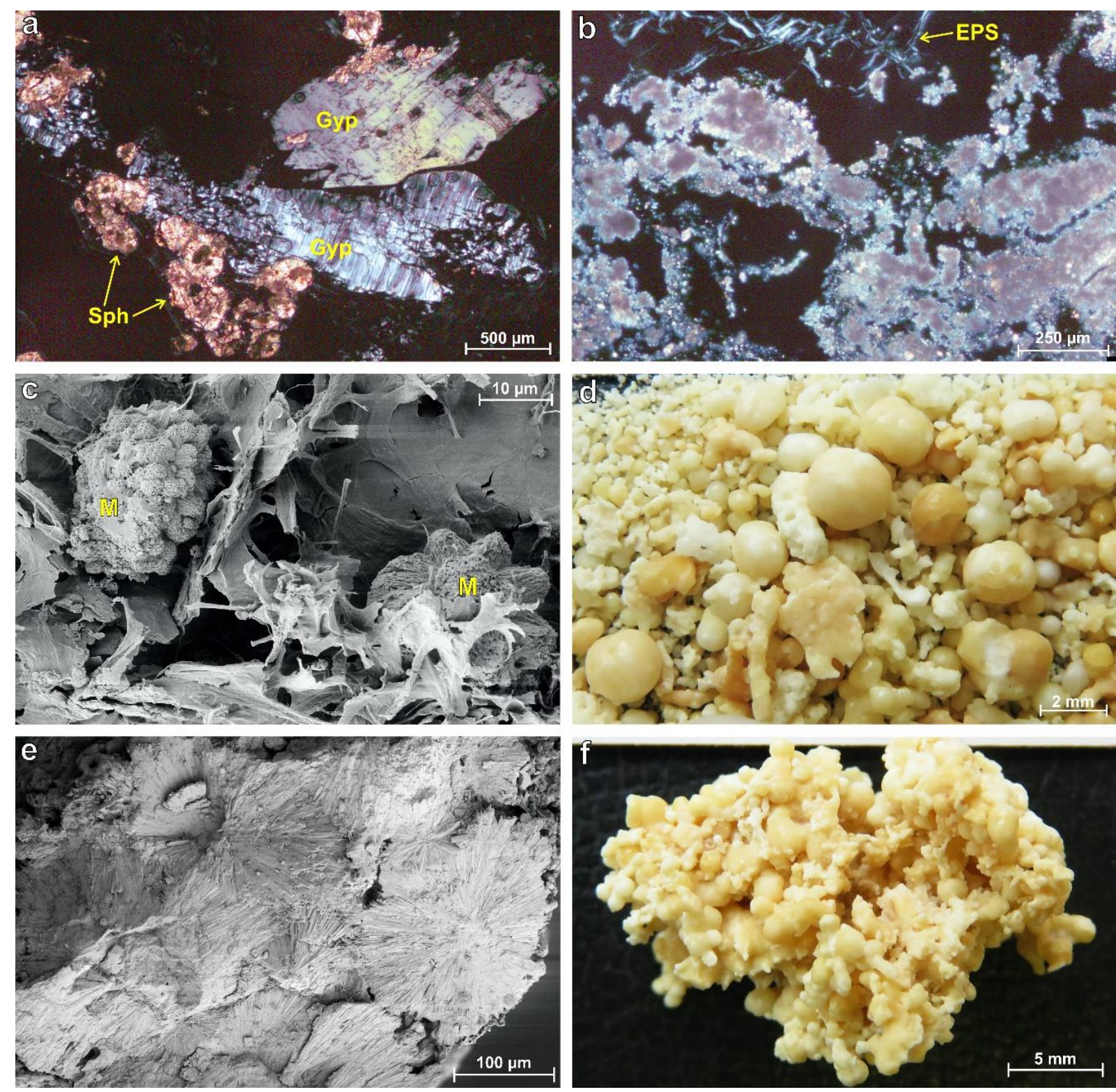

Figure 4.4 Mineral precipitates observed within the studied microbial mat. (a) Cross-polarized light photomicrograph of gypsum crystals (Gyp) and subspherical aragonite particles (Sph) from Layer 1. (b) Cross-polarized light photomicrograph of irregular micritic aggregates from Layer 6, showing their micropeloidal internal texture. Yellow arrow points to thick and birefringent EPS threads. (c) SEM image of an irregular micritic aggregate from Layer 1, showing a detail of its micropeloids (M), formed by intergrown bundles of aragonite needles, and completely surrounded by a matrix of EPS, whithin which they precipitate. (d) Close-up picture of the loose mineral particles extracted from Layer 2 after complete removal of the organic matter. Note the presence of both subspherical particles and irregular aggregates. (e) SEM image showing a section of coalesced subspherical particles from Layer 2. Note their fibrous radial structure formed by aragonite needles. (f) Large irregular carbonate aggregate from Layer 4 after complete removal of organic matter. Note that it is formed by the coalescence of both subspherical particles and micritic aggregates. Large complex aggregates are typical from the lower older layers of the mat (compare with the younger precipitates of Figure 4.4d). 

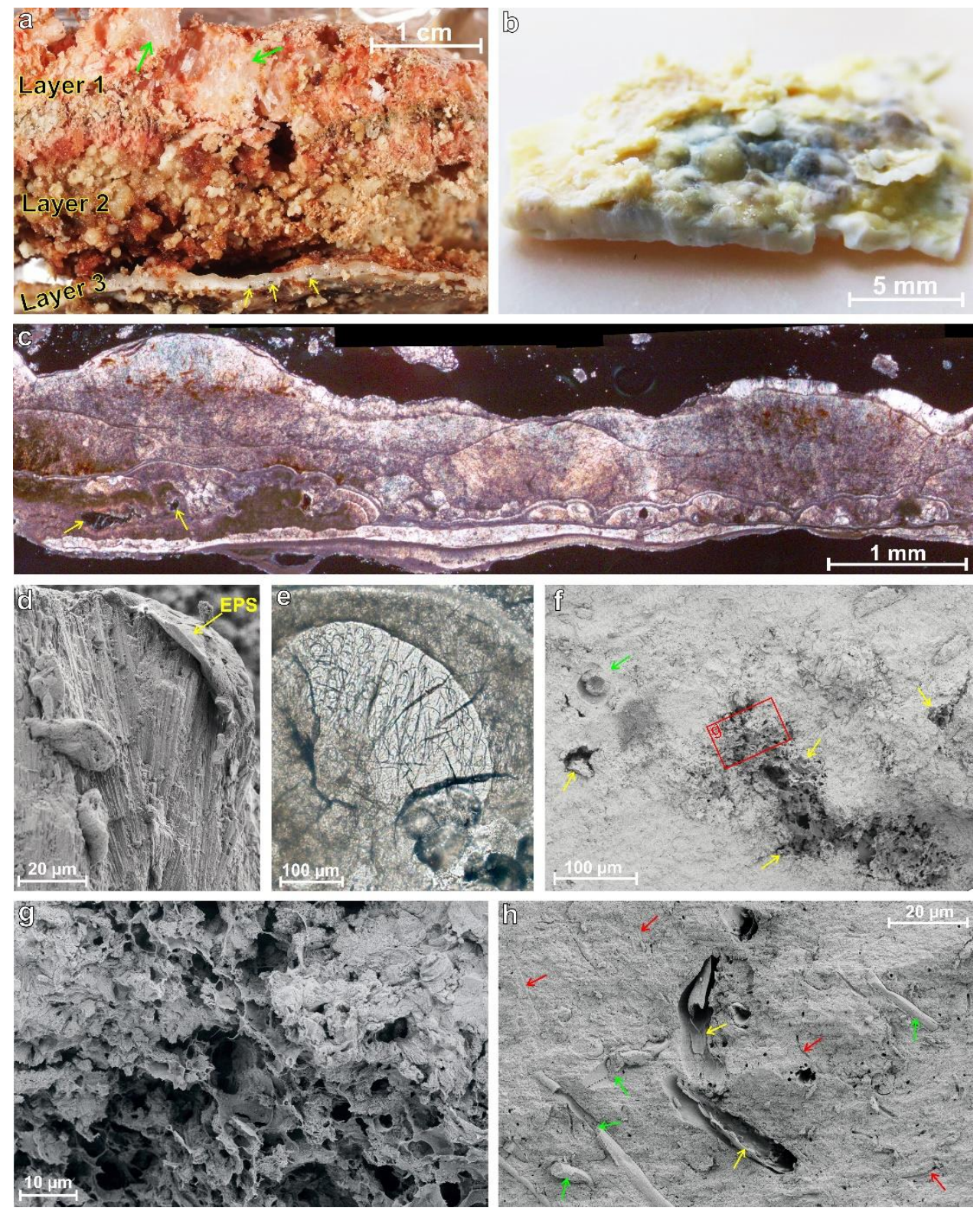

Figure 4.5 Layer 3. (a) Close-up picture of the upper part of the studied mat. Green arrows point to transparent gypsum crystals. Yellow arrows point to dark-coloured cavities within the mineral crust of Layer 3. (b) Close-up picture of the mineral crust of Layer 3 after complete removal of organic matter. Note the botryoidal upper surface of the crust and its local dark colour. (c) Cross-polarized light photomicrograph of a thin section of the mineral crust of Layer 3, showing its internal structure, composed of several superposed laminae of botryoidal carbonate, indicating different precipitation episodes. Yellow arrows point to cavities within the crust, filled by organic matter. (d) SEM image showing the fibrousradial structure of a carbonate botryoid from Layer 3, formed by aragonite needles, and covered by a thin film of EPS. (e) Transmitted light photomicrograph showing a detail of a carbonate botryoid from Layer 3. Note the fibrous-radial internal texture and the presence of very abundant curved dark filaments. Cloudier aspect of the outer part is due to a higher abundance of dark filaments. (f) SEM image of a freshly-cut section of layer 3, showing irregular and partially-filled cavities (yellow arrows) and a section of a foraminifer (green arrow). Red rectangle marks the position of Figure 4.5g. (g) Detail of the SEM image of Figure 4.5f, showing the EPS matrix that infills the cavities observed within the mineral crust of Layer 3. (h) Close-up SEM view of a freshly-cut section of the mineral crust of Layer 3, showing moulds of diatoms (green and yellow arrows) and much more abundant small filaments (red arrows) included within the mineral crust. Most diatom moulds are filled by carbonate (green arrows) but locally others are partially empty, with some remains of EPS (yellow arrows). 
The upper and lower parts of the mat (separated by the crust of layer 3) show significant differences not only in their size and abundance of mineral precipitates, but also in the EPS matrix where the minerals occur. The upper layers (1-2) have a denser, more cohesive and viscous organic matrix, with a dense reticulate microstructure formed by a net of intertwined delicate EPS fibres (Figures 4.6a-b), whereas the lower layers (4-6) have a much less dense and less abundant matrix between the mineral precipitates (causing their crumbly texture), and this matrix shows a porous laminated microstructure with coarser and parallel-oriented individual EPS fibres, which include many nano- to micro-scale precipitates and which, unlike fresher EPS fibres, show birefringence under cross-polarized light (Figures 4.6c-d; cf. Arp et al., 1998; Arp et al., 1999a).
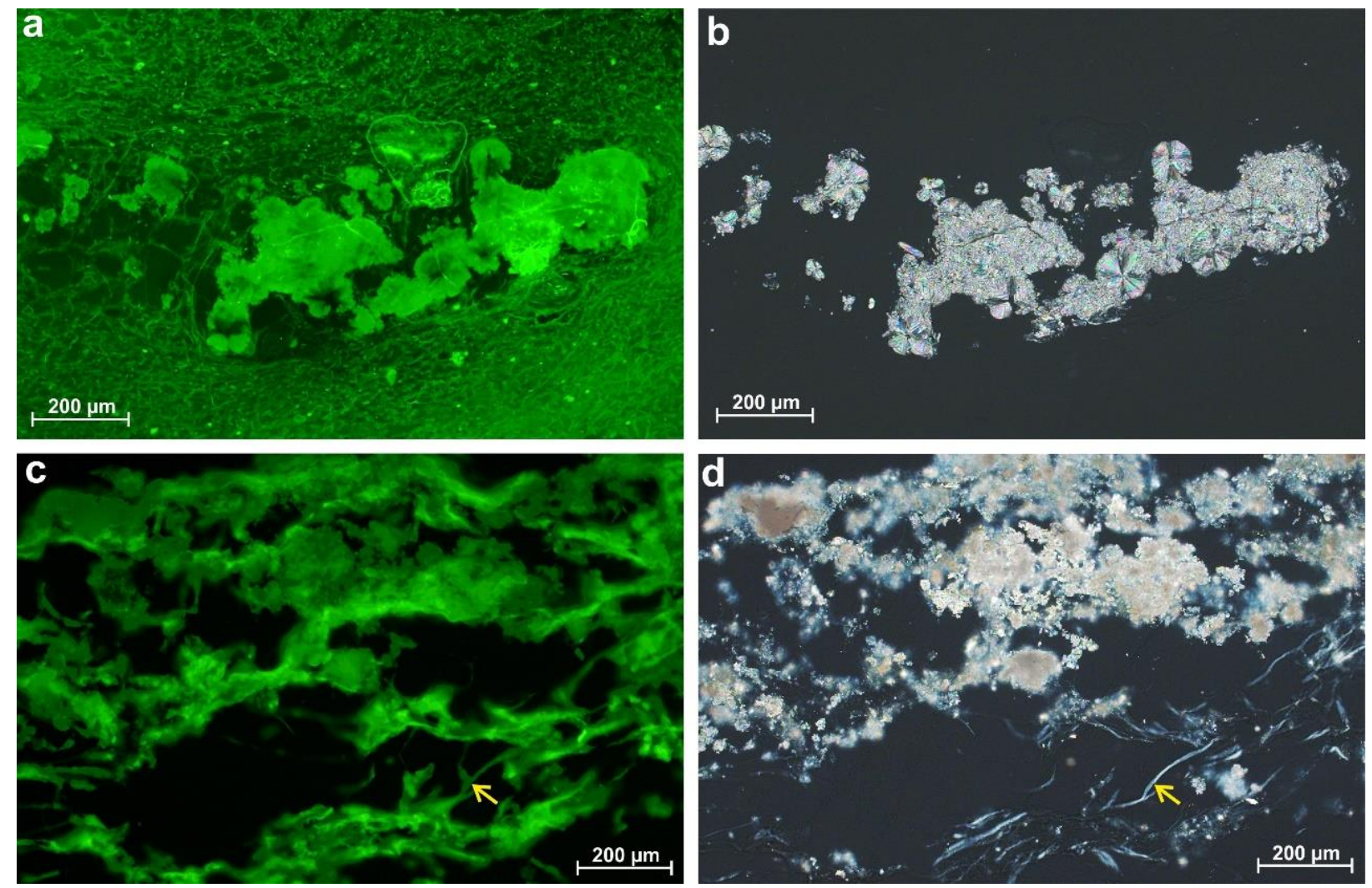

Figure 4.6 Different preservation of EPS. (a, c) Photomicrographs taken with fluorescence microscope. (b, d) Same areas as a, c, but seen with cross-polarized light. (a-b) Carbonate precipitates from the topmost Layer 1, within a dense reticulate net of intertwined delicate fibres of younger and fresher EPS, which show no birefringence (black colour in b) with cross-polarized light. (c-d) Carbonate precipitates from the lowermost Layer 6, forming in a less dense and more porous matrix of older EPS with a laminated microstructure of coarser individual EPS fibres, which show birefringence (yellow arrow in d) with crosspolarized light. 


\subsubsection{Bulk data}

Bulk geochemical data for individual mat layers are shown in Table 4.1 (a: bulk sample before decalcification) and (b: extraction residues after decalcification). In Table 4.1a, $\mathrm{C}_{\text {org }}$ showed relatively high contents in layers 1 and 2 (4.7\% and 6.2\%), sharply decreased in layer $3(1.7 \%)$ and sustained in low contents for all deeper mat layers $(1.2 \%-1.5 \%)$, which is concordant with the more abundant, fresher organic matrix observed in the younger phase of mat layers 1-2. The $\mathrm{CaCO}_{3}$ concentration significantly increased with mat depth, whose lowest content was observed in layer 1 (27.1\%). A remarkable enrichment in $\mathrm{CaCO}_{3}$ occurred in layer $2(73.1 \%)$ and followed by a constant high amounts $(>90 \%)$ in deeper parts of the mat, as also reflected by the microscopic observation of an increase in abundance of mineral precipitates downwards in the mat. Contrarily, S amounts significantly deceased with depth, with the highest abundance occurring in layer 1 (9.78\%) as a result of gypsum precipitates. Below, in layer $2, \mathrm{~S}$ markedly dropped to $1.2 \%$, and kept in low concentration in the older phase of the mat (c. $0.3 \%-0.5 \%$ ). For $\mathrm{N}$, it showed generally low amounts throughout the mat profile $(0.14 \%-0.74 \%)$.

Table 4.1a Bulk geochemical data for the microbial mat layers (original mat layers; data from Shen et al., 2019).

\begin{tabular}{|c|c|c|c|c|c|c|c|c|}
\hline Layers & $\mathrm{C}_{\text {tot }}(\%)$ & $\mathrm{C}_{\text {org }}(\%)$ & $\mathrm{C}_{\text {carb }}(\%)$ & $\begin{array}{c}\mathrm{CaCO}_{3} \\
(\%)\end{array}$ & $\mathrm{N}_{\text {tot }}(\%)$ & $\mathrm{S}_{\text {tot }}(\%)$ & $\mathrm{C}_{\text {org }} / \mathrm{N}$ & $\mathrm{C}_{\text {org }} / \mathrm{S}$ \\
\hline 1 & 7.94 & 4.69 & 3.25 & 27.10 & 0.41 & 9.78 & 11.40 & 0.50 \\
\hline 2 & 15.00 & 6.23 & 8.77 & 73.10 & 0.74 & 1.21 & 8.40 & 5.20 \\
\hline 3 & 12.59 & 1.71 & 10.88 & 90.70 & 0.16 & 0.33 & 10.50 & 5.10 \\
\hline 4 & 12.33 & 1.33 & 11.00 & 91.70 & 0.19 & 0.49 & 7.00 & 2.70 \\
\hline 5 & 12.45 & 1.47 & 10.98 & 91.50 & 0.20 & 0.52 & 7.30 & 2.80 \\
\hline 6 & 12.23 & 1.20 & 11.03 & 91.90 & 0.14 & 0.48 & 8.50 & 2.50 \\
\hline
\end{tabular}

Table 4.1b Bulk geochemical data for the microbial mat layers (extraction residues; modified after Blumenberg, Thiel and Reitner, 2015).

\begin{tabular}{|c|c|c|c|c|c|}
\hline Layers & $\mathrm{C}_{\text {org }}(\%)$ & $\mathrm{N}_{\text {tot }}(\%)$ & $\mathrm{S}_{\text {tot }}(\%)$ & $\mathrm{C}_{\text {org }} / \mathrm{N}$ & $\mathrm{C}_{\text {org }} / \mathrm{S}$ \\
\hline 1 & 15.2 & 1.9 & 10.4 & 7.9 & 1.5 \\
\hline 2 & 32.8 & 4.9 & 2.9 & 6.7 & 11.4 \\
\hline 3 & 37.3 & 5.6 & 4.6 & 6.7 & 8.2 \\
\hline 4 & 37.0 & 6.2 & 2.6 & 6.0 & 14.4 \\
\hline 5 & 40.1 & 6.7 & 2.0 & 6.0 & 20.3 \\
\hline 6 & 42.3 & 6.6 & 2.0 & 6.4 & 21.4 \\
\hline
\end{tabular}


In the decalcified extraction residue (Table 4.1b), $\mathrm{C}_{\text {org }}$ increased significantly with depth, showing a broad range from $15.2 \%$ to $42.3 \%$. Similarly, $N$ appeared an enhanced concentration in the deeper parts, with the highest value occurred in layer $5(6.7 \%)$. Unlike the trend of N, S sharply decreased with depth, with the highest concentration found in the uppermost layer $1(10.4 \%)$.

\subsubsection{Qualitative GC-amenable hopanoids and FAs}

GC-amenable hopanoids were detected in the freely extractable lipids, i.e., hop-22(29)-ene (diploptene), $\beta \beta$-bishomohopanoic acid, $\beta \beta$-bishomohopanol (see Table C.1). In general, the summed major hopanoids decreased with depth, with the highest abundance in layer 1 (16.67 $\mu \mathrm{g} / \mathrm{g}$ dry mat) and the lowest abundance in layer 4 (3.34 $\mu \mathrm{g} / \mathrm{g}$ dry mat) (see Table C.3). Like hopanoids, summed FAs (i.e., iso-/anteiso- $\mathrm{C}_{15}-\mathrm{C}_{17}$ and unsaturated $\mathrm{C}_{18: 1}$ and $\mathrm{C}_{19: 1} \mathrm{FAs}$ ) significantly decreased in abundance with depth. The highest abundance was found in layer 1 (212.72 $\mu \mathrm{g} / \mathrm{g}$ dry mat) and the lowest abundance, was two orders less abundant, occurring in layer 3 (3.34 $\mu \mathrm{g} / \mathrm{g}$ dry mat) (see Table C.3).

Fewer hopanoids (i.e. hop-17(21)-ene and $\beta \beta$-bishomohopanoic acid) were observed in the carbonate-bound lipid fraction, with no consistent behaviour with mat depth. For instance, the concentrations of the summed hopanoids were, by two orders, less abundant $\left(10^{-1} \mu \mathrm{g} / \mathrm{g}\right.$ dry mat) in the upper layer 2 as compared to the abundance in the free lipids (see Table C.4). Thereafter, the summed hopanoids markedly enhanced in the carbonate layer 3 , which were in the same order $\left(10^{0} \mu \mathrm{g} / \mathrm{g}\right.$ dry mat $)$ as they showed in the free lipids. These hopanoids significantly decreased again downwards in the mat. For FAs, similar major groups (i.e., isolanteiso- $\mathrm{C}_{15}-\mathrm{C}_{17}$ and unsaturated $\mathrm{C}_{18: 1}$ and $\mathrm{C}_{19: 1} \mathrm{FAs}$ ) were observed in the carbonate-bound lipid fraction, and the summed concentration, were in the same order $\left(10^{0} \sim 10^{1} \mu \mathrm{g} / \mathrm{g}\right.$ dry mat range) as they did in the free lipids. FAs in the carbonate-bound lipid fraction were an order of magnitude less abundant compared to the topmost layer 1 in the free lipids $\left(10^{2} \mu \mathrm{g} / \mathrm{g}\right.$ dry mat range, see Table C.3 and $\underline{\text { C.4 }}$ ). Likewise, the summed FAs first showed an increase until layer 3 (highest concentration: $80.45 \mu \mathrm{g} / \mathrm{g}$ dry mat), and followed by a sharp decrease in the deeper parts, with the lowest values observed for layer $5(6.87 \mu \mathrm{g} / \mathrm{g}$ dry mat; see Table C.4). Further, in addition to the conventional FAs (i.e., iso-/anteiso-, unsaturated and saturated FAs), small quantities of dicarboxylic acids $\left(\mathrm{C}_{21}-\mathrm{C}_{28} ; 10^{-1} \mu \mathrm{g} / \mathrm{g}\right.$ dry mat, see Table C.2 $)$ were exclusively observed in the carbonate-bound lipids, but only in layers 3 and $4\left(10^{-1} \mu \mathrm{g} / \mathrm{g}\right.$ dry mat). 


\subsubsection{Steroids vs. hopanoids and fatty acids}

Depth distribution of the summed concentrations of the major GC-amenable hopanoids, FAs, and steroids are presented in Figure 4.7. In the freely extractable lipid fractions (Figure 4.7a), the abundance of total steroids significantly decreased (by $>90 \%$ ) immediately below the topmost layer 1 , and they kept at a trace amount $\left(10^{-1} \mu \mathrm{g} / \mathrm{g}\right.$ dry mat $)$ in the deeper part of the mat. Likewise, hopanoids and FAs also showed a general decrease in abundance with mat depth; however, both compounds appeared an enhancement in the older phase of the mat. Further, the concentration of FAs showed many folds more abundant as compared to hopanoids and steroids observed for layer 1, but the distributions of the three compound classes resemble each other (high amounts in layer 1, low amounts in layer 3 and 4, Figure 4.7a). Quite similar distributions were observed when the compound concentrations were plotted against $\mathrm{C}_{\mathrm{org}}$, due to relatively low organic carbon throughout the mat $(1.20-6.23 \%$, Table 4.1a, Figure 4.7a).

In the carbonate-bound lipids, total steroids showed overall low abundance within the mat profile and no steroids were detected in the topmost layer 1. Hopanoids was likewise not detected in layer 1. Its abundance significantly increased until layer 3, but decreased again in the lower mat. For the FAs, also in the carbonate-bound lipid fractions, the concentrations were much more abundant than hopanoids and steroids. Similarly, FAs also remarkably enhanced in the upper layers, but sharply decreased again in the lower part of the mat. Largely identical distribution was observed when these compound classes were plotted against $\mathrm{C}_{\text {org }}$ (Figure 4.7b). Notably, the highest abundances of hopanoids and FAs were both observed in layer 3 (Table C.4; Figure 4.7b).

\subsubsection{Pyrolysis}

In addition to the soluble lipids (including freely extractable and carbonation-bound fractions), the decalcified extraction residues were analyzed using Py-GC-MS. Ion chromatograms representing steroids (i.e. including sterenes, steranes and sterols) and hopanoids are shown in Figure C.1. No steroids were detected in the pyrolysates throughout the mat, while hopanoids presented in the insoluble matter of each mat layers (layer 1 appeared trace amount, and the relative abundance gradually increased with depth). 


\section{Freely extractable lipids}

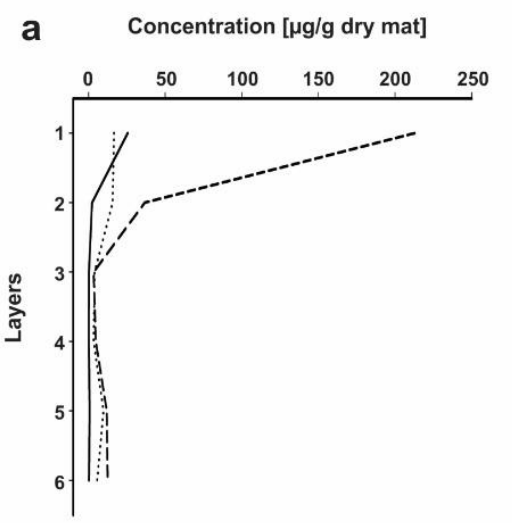

Concentration $\left[\mu \mathrm{g} / \mathrm{g} \mathrm{C}_{\text {org }}\right]$

$\mathrm{C}_{\text {org }}[\%]$

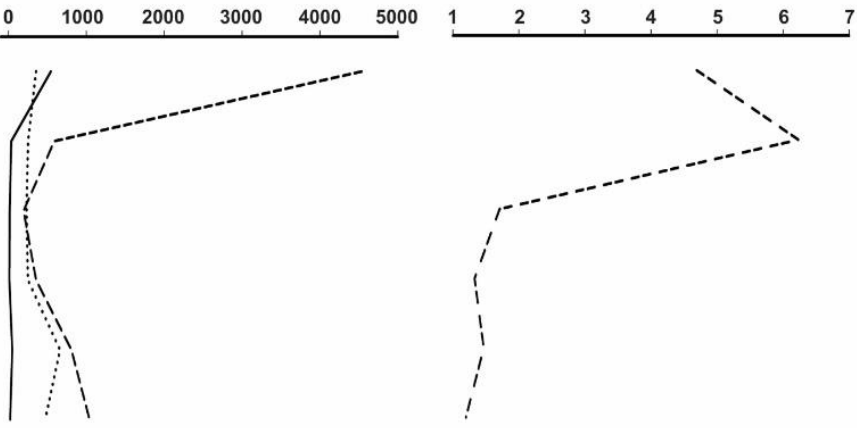

Steroids

Hopanoids

------- Fatty acids

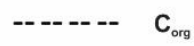

\section{Carbonate-bound lipids}

b Concentration [ $\mu \mathrm{g} / \mathrm{g}$ dry mat]
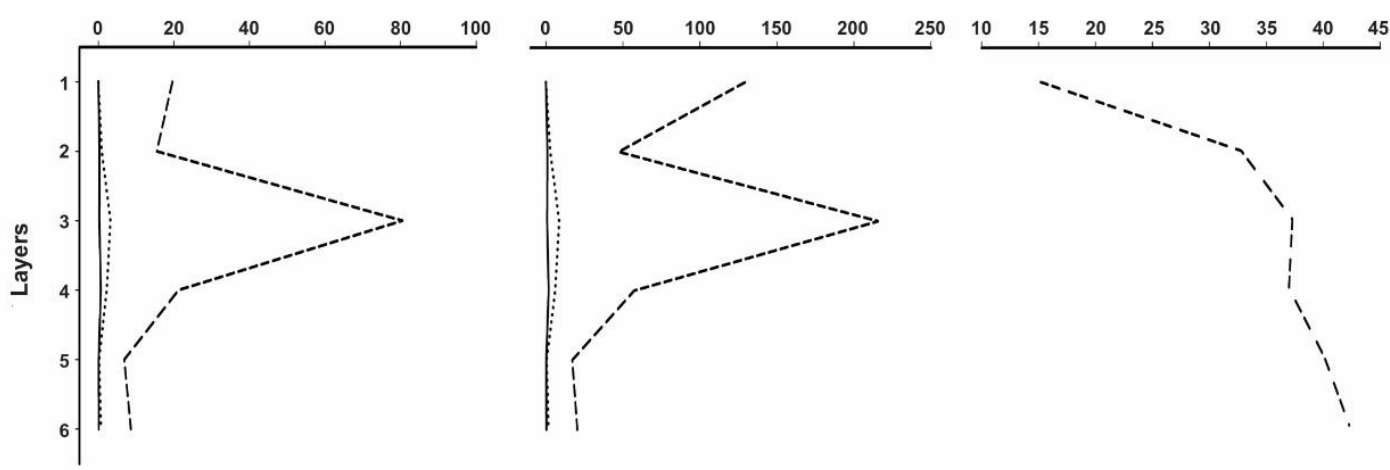

$\longrightarrow$ Steroids

Hopanoids

Fatty acids

----- $C_{\text {org }}$

Figure 4.7 Depth distribution of steroids, hopanoids, fatty acids ( $\mu \mathrm{g} / \mathrm{g}$ dry mat; $\mu \mathrm{g} / \mathrm{g}$ Corg), and Corg (wt. $\%$ ) in the microbial mat layers, (a) free- lipids, and (b) carbonate-bound lipids.

\subsubsection{Carbon isotopic compositions of microbial lipids and hydrocarbons}

FAs (including $\mathrm{C}_{14}-\mathrm{C}_{26}$ homologues), and hopanoids (including $\mathrm{C}_{30}$ hopene and $\mathrm{C}_{32}$ hopanol) as well as unique hydrocarbon ( $\mathrm{C}_{17} n$-alkanes) were identified. GC-C-IRMS measurements revealed relatively high $\delta^{13} \mathrm{C}$ values in both lipid fractions of the studied mat, which range from -15.4 to $-20.7 \%$ for $\mathrm{C}_{17} n$-alkanes, -4.4 to $16.4 \%$ for FAs, -17.6 to $-20.2 \%$ for hopanoids, and -7.2 to $-13.3 \%$ for sterols (Table 4.2 ). 
Table 4.2 Carbon isotopic signatures of lipid biomarkers observed in the studied mat (unit: \%o relative to V-PDB; n.d.=not detected; $C_{31} \Delta^{0}$ data from Shen et al., 2019).

\begin{tabular}{|c|c|c|c|c|c|c|c|c|}
\hline \multirow{2}{*}{ Layer } & \multicolumn{2}{|c|}{1} & \multicolumn{2}{|c|}{3} & \multicolumn{2}{|c|}{5} & \multicolumn{2}{|c|}{6} \\
\hline & $\begin{array}{c}\text { Freely } \\
\text { extractable } \\
\text { lipids }\end{array}$ & $\begin{array}{c}\text { Carbonate- } \\
\text { bound } \\
\text { lipids }\end{array}$ & $\begin{array}{c}\text { Freely } \\
\text { extractable } \\
\text { lipids }\end{array}$ & $\begin{array}{c}\text { Carbonate- } \\
\text { bound } \\
\text { lipids }\end{array}$ & $\begin{array}{c}\text { Freely } \\
\text { extractable } \\
\text { lipids }\end{array}$ & $\begin{array}{c}\text { Carbonate- } \\
\text { bound } \\
\text { lipids }\end{array}$ & $\begin{array}{c}\text { Freely } \\
\text { extractable } \\
\text { lipids }\end{array}$ & $\begin{array}{c}\text { Carbonate- } \\
\text { bound } \\
\text { lipids }\end{array}$ \\
\hline \multicolumn{9}{|l|}{$n$-alkanes } \\
\hline 17 & -15.4 & -16.1 & -18.7 & -20.7 & -17.3 & -17.4 & -15.8 & -15.7 \\
\hline \multicolumn{9}{|l|}{ FAs } \\
\hline $14: 0$ & -8.5 & n.d. & n.d. & n.d. & n.d. & n.d. & n.d. & n.d. \\
\hline iso-15 & n.d. & n.d. & n.d. & -11.8 & n.d. & -16.4 & n.d. & -12.1 \\
\hline $15: 0$ & -4.4 & -8.6 & n.d. & -4.7 & n.d. & n.d. & n.d. & -11.0 \\
\hline $16: 1$ & -9.4 & -8.7 & n.d. & n.d. & n.d. & n.d. & n.d. & n.d. \\
\hline iso-16 & n.d. & -9.3 & n.d. & -12.6 & n.d. & 12.4 & n.d. & -12.9 \\
\hline $16: 0$ & -6.8 & $\begin{array}{l}-12.8 \\
\end{array}$ & n.d. & -16.4 & n.d. & $\begin{array}{l}-14.3 \\
\end{array}$ & n.d. & -13.7 \\
\hline iso-17 & n.d. & n.d. & n.d. & n.d. & n.d. & -9.3 & n.d. & -12.8 \\
\hline anteiso-17 & n.d. & n.d. & n.d. & n.d. & n.d. & -10.5 & n.d. & -12.0 \\
\hline $17: 0$ & -4.8 & n.d. & n.d. & -12.9 & n.d. & $\begin{array}{ll}-13.8 \\
\end{array}$ & n.d. & -13.3 \\
\hline $18: 1$ & -11.6 & -11.4 & n.d. & n.d. & n.d. & n.d. & n.d. & n.d. \\
\hline 18:0 & n.d. & -11.4 & n.d. & -14.3 & n.d. & -12.5 & n.d. & -12.9 \\
\hline 19:1 & -11.8 & -10.7 & n.d. & -16.3 & -15.0 & -13.8 & n.d. & -12.9 \\
\hline $24: 0$ & n.d. & n.d. & n.d. & -14.8 & -8.5 & -14.4 & -7.8 & -15.1 \\
\hline $26: 0$ & n.d. & n.d. & n.d. & -14.5 & n.d. & n.d. & n.d. & -15.9 \\
\hline \multicolumn{9}{|l|}{ Sterols } \\
\hline $\mathrm{C}_{31} \Delta^{0}$ & -7.2 & n.d. & n.d. & n.d. & -12.5 & n.d. & -13.3 & n.d. \\
\hline \multicolumn{9}{|l|}{ Hopanoids } \\
\hline $\mathrm{C}_{30}$ hopene & n.d. & n.d. & n.d. & n.d. & -20.2 & n.d. & -18.5 & n.d. \\
\hline $\mathrm{C}_{32}$ hopanol & n.d. & n.d. & n.d. & n.d. & -17.6 & n.d. & -17.8 & n.d. \\
\hline
\end{tabular}

Low concentrations of lipid biomarkers restricted measurements of $\delta^{13} \mathrm{C}$ values in the studied mat, and thus the general trend with respect to isotope signatures between free and carbonate-lipids are not conceivable here. Nonetheless, of all the identifiable isotopic signals, we observe several $\delta^{13} \mathrm{C}$ values of FAs (e.g. $\mathrm{C}_{19: 1}$ ) are more enriched in the carbonate-bound phases than the free lipids, some cases (e.g. $\mathrm{C}_{16}$ ) are vice versa, and certain FAs (e.g. $\mathrm{C}_{18: 1}$ ) showed similar isotopic signatures in both lipid pools.

In general, short-chain FAs (including $\mathrm{C}_{14}-\mathrm{C}_{17}$ ) showed highly enriched $\delta^{13} \mathrm{C}$ values (ranging from -4.4 to $-14.3 \%$ ), while ${ }^{13} \mathrm{C}$-depletion were observed for their long-chain homologues (including $\mathrm{C}_{18}-\mathrm{C}_{26}$; ranging from -10.7 to $-16.3 \%$ ) within the studied mat. Exceptions are two depleted $\delta^{13} \mathrm{C}$ values for short-chain FAs (iso- $\mathrm{C}_{15}$ and $\mathrm{C}_{16}$ ) showing -16.4 $\%$, and two ${ }^{13} \mathrm{C}$-enriched signatures for long-chain $\mathrm{C}_{24} \mathrm{FAs}$ with $-7.8 \%$. 
Further, $\delta^{13} \mathrm{C}$ values for FAs in the deeper, older phase of the studied mat were consistently depleted by c. $0.2-11.5 \%$ as compared to the top layer 1 (see Table 4.2). This depletion trend was even biased in the mineral crust of layer 3 , as evident from more ${ }^{13} \mathrm{C}$-depleted values for the long-chain FAs as well as $\mathrm{C}_{17} n$-alkanes observed therein (see Table 4.2). Another characteristic feature of carbon isotopic distribution in the studied mat is that much lighter ${ }^{13} \mathrm{C}$ contents observed for the hopanoids compared to the other lipids (see Table 4.2), ranging from -17.6 to $-20.2 \%$.

\subsubsection{Carbon isotopic signatures of bulk carbonate}

Two different types of bulk carbonate (fine particles and ooids) were measured for carbon isotopes, and positive values were obtained from these carbonate $(+1.7$ to $+6.9 \%$; see Table 4.3). In the deeper layers 5 and $6, \delta^{13} \mathrm{C}_{\text {ooid }}$ exhibited by $2.5 \%$ more enriched than their counterparts, fine particles. In addition, a general ${ }^{13} \mathrm{C}$-enrichment in the mineral crust of layer 3 was observed within the mat.

Table $4.3 \delta^{13} \mathrm{C}$ values of bulk carbonate (Fine particles and Ooid, carbonate crust of layer 3 ) as well as $\Delta \delta^{13} \mathrm{C}$ values between FA and bulk carbonate in the studied mat (TLE1: freely extractable lipid, TEL2: carbonate-bound lipid; $\Delta \delta^{13} \mathrm{C}_{\text {(FA-carbfine) }}$ and $\Delta \delta^{13} \mathrm{C}_{\text {(FA-carbooid); }}$ unit: \%o relative to V-PDB; n.d.=not detected; n.a. $=$ not analysed).

\begin{tabular}{|c|c|c|c|c|c|c|c|c|c|}
\hline$\delta^{13} \mathrm{C}_{\text {bulk }}$ Layer & \multicolumn{2}{|c|}{1} & 2 & 3 & 4 & \multicolumn{2}{|c|}{5} & \multicolumn{2}{|c|}{6} \\
\hline Fine particles & \multirow{2}{*}{\multicolumn{2}{|c|}{$\begin{array}{c}+1.7 \\
\text { n.d. }\end{array}$}} & +4.8 & \multirow{2}{*}{+6.5} & +5.7 & \multirow{2}{*}{\multicolumn{2}{|c|}{$\begin{array}{r}+4.3 \\
+6.9\end{array}$}} & \multirow{2}{*}{\multicolumn{2}{|c|}{$\begin{array}{r}+4.1 \\
+6.5 \\
\end{array}$}} \\
\hline Ooid & & & +4.9 & & +5.0 & & & & \\
\hline$\Delta \delta^{13} \mathrm{C}_{\text {(FA-particle) }}$ & $\begin{array}{l}\text { TLE1 } \\
-11.8\end{array}$ & $\begin{array}{l}\text { TLE2 } \\
-13.2\end{array}$ & n.a. & -21.8 & n.a. & $\begin{array}{l}\text { TLE1 } \\
-13.6\end{array}$ & $\begin{array}{l}\text { TLE2 } \\
-15.6\end{array}$ & $\begin{array}{l}\text { TLE1 } \\
-11.9\end{array}$ & $\begin{array}{l}\text { TLE2 } \\
-17.3\end{array}$ \\
\hline$\Delta \delta^{13} \mathrm{C}_{\text {(FA-ooid) }}$ & & & n.a. & -21.8 & n.a. & $\begin{array}{l}\text { TLE1 } \\
-16.2\end{array}$ & $\begin{array}{l}\text { TLE2 } \\
-18.2\end{array}$ & $\begin{array}{l}\text { TLE1 } \\
-14.3\end{array}$ & $\begin{array}{l}\text { TLE2 } \\
-19.7\end{array}$ \\
\hline
\end{tabular}




\subsection{Discussion}

\subsubsection{Growth history of the microbial mat}

The microscopic study presented here (see section 4.3.1), together with the ${ }^{14} \mathrm{C}$ dates (Figure 4.1d; Blumenberg et al., 2015) indicate that the studied microbial mat records two distinct phases of mat development, separated by the mineral crust of layer 3 and with dissimilar growth rates (Figures 4.2c, 4.3). The older phase is represented by the three lower layers (4-6, c. $7 \mathrm{~cm}$ thick, Figures $4.2 \mathrm{c}, \underline{4.3}$ ), which formed in less than 350 years (from $1440 \pm 40$ to $1111 \pm 40$ years BP). The younger phase is represented by the two upper layers $(1-2$, c. $3 \mathrm{~cm}$ thick, Figures 4.2c, 4.3), which formed in more than 550 years (from $551 \pm 40$ to $62 \pm 40$ years BP) and maybe up to 1000 years (if we take into account the age of the underlying layer 3, $1111 \pm 40$ years BP). Despite their differences in age and in accretion rate (the younger and thinner phase seems to have accreted at a much slower rate than the older phase, cf. Figure 4.1d), both phases show similar mineral composition, being mainly formed by irregular micritic aggregates and subspherical particles. These types of carbonate precipitates are not only common in Kiritimati but in all microbialites. In particular, the micropeloidal texture of the irregular micritic aggregates (Figures 4.4, 4.6) is very commonly described in most modern and fossil microbialites throughout their long geological history, since the Archean.

The main difference between the mineral precipitates of both growth phases of the studied microbial mat is their abundance, size and development. In the lower layers, precipitates are more abundant than in the upper layers, and they tend to be coalesced in larger aggregates (Figures 4.3, 4.4). This is easily explained by the fact that they have had a longer time to precipitate since their formation, between 1440 and 1111 years BP, than the precipitates of the younger $(<550$ years BP) upper layers. In addition, the lower layers also show a less abundant and more degraded EPS matrix than the upper layers, where this matrix is fresher and denser (Figure 4.6), which is consistent with the lower $\mathrm{C}_{\text {org }}$ content in the older layers $(1.20 \%-1.47 \%$, see Table 4.1b), compared with the upper layers (4.69-6.23\%, see Table 4.1b) indicating a general increase in $\mathrm{OM}$ degradation downwards in the mat. The coincidence of this taphonomic evolution of EPS with the downwards increase in mineral size and abundance shows and supports the commonly stated role of the degradation of microbial EPS as a trigger to mineral precipitation and to the formation of microbialites (e.g. Arp et al., 1998; Arp et al., 1999b; Dupraz et al., 2009; Reitner et al., 1995). Therefore, the upper and lower parts of the studied sample may be interpreted as two different growth phases of relatively similar microbial mats, formed under probably similar environmental conditions, but representing 
different development stages: the upper part being the earliest steps of mineralization and the lower part representing a more evolved proto-microbialite, after $\sim 1400$ years of degradation of EPS and of mineral precipitation.

Interestingly, the boundary between those two development stages of the mat is marked by the mineral crust of layer 3, which shows strong contrasts with the other layers (Figure 4.5). The ${ }^{14} \mathrm{C}$ dates (Figure 4.1d; Blumenberg et al., 2015) and the microscopic study of the crust suggest that it was formed during an interruption in microbial mat accretion, c. 1100 years BP. During this hiatus the microbial mat did not develop as it had in the previous c. 350 years, probably due to an environmental change. This hypothesis is supported by the biotic change that can be inferred from the organisms and their traces preserved within the crust: very abundant filamentous microbes and diatoms, with less common foraminifera (Figures 4.5e-h). Foraminifera do occur in the modern surface of the living mat (Layer 1), and they are also preserved in older layers, but diatoms and filamentous microbes are absent or much less common in other layers, being only locally preserved as molds within some mineral precipitates of Layers 4-6. Furthermore, the significant contrast in the mode of mineral precipitation observed in layer 3 also points to environmental changes. The $\mu \mathrm{m}$-scale superposition of fibrous-radial botryoidal laminae (Figure 4.5c) indicates that precipitation was episodic, occurring repeatedly but only during favorable moments. Similar botryoidal or fan-like fibrous-radial fabrics with microbial filament remains have been described in fossil microbialites interpreted as formed under large hydrological variations, ranging from freshwater to hypersaline conditions (Camoin et al., 1997). In Kiritimati, the only similar microfabric has been described locally as fibrous aragonite veneers interpreted to precipitate at low supersaturation (Arp et al., 2012). The fact that Kiritimati lakes may experience inflow of fresh groundwater (Saenger et al., 2006) makes it plausible that the hiatus represented by layer 3 and the precipitation of its mineral crust are related to a hydrochemical change in Lake 2 , due to freshwater input, which would reduce salinity and alkalinity and could prompt a biotic change, interrupting the former microbial mat accretion and promoting the occurrence of a much thinner biofilm dominated by filamentous microbes and diatoms, with foraminifera being less abundant. In this context, carbonate precipitation would occur only when supersaturation sporadically increased, and it would be relatively fast, allowing the rapid entombment of most biofilm organisms. After this anomalous period, a new change back to hypersaline conditions would reinstate the accretion of a new microbial mat (layers 1-2) 
similar (in biotic composition and in mode of mineral precipitation) to the older one (layers 4$6)$.

\subsubsection{Depth distributions of steroids vs. hopanoids and fatty acids (FAs)}

Significant amounts of unspecific $\mathrm{C}_{18}$ and $\mathrm{C}_{19}$ FAs as well as certain amounts of iso-/anteiso$\mathrm{C}_{15}-\mathrm{C}_{17}$ were observed in the free lipids. These FAs occur commonly in many bacteria (Anhalt and Fenselau, 1975; Kates, 1964). In the upper layers (1-3), the abundances of FAs and hopanoids drastically dropped (Figure 4.7a). Thereafter, in the deeper layers (4-6), hopanoids and FAs slightly increased in abundance. For the steroids, it shows a significant decrease in the abundance in the upper mat layers and retained a low amounts in the deeper parts. These observations suggest that steroids, FAs and hopanoids suffered from microbial degradation during further growth of the mat. The general decreasing trend of hopanoids in the mat studied is contrasting with the previous study that described an increasing hopanoids with depth from another microbial mat (Lake 22; Shen et al., 2018). However, the enhancement of hopanoids in the deeper parts of the mat studied could be interpreted as the diagenetic products of bacteriohopanepolyols (BHPs; Rohmer, Bouvier-Nave and Ourisson, 1984). We assume that one part of BHPs yielded the observed GC-amenable hopanoids via the progressive defunctionalisation process. Another part of BHPs (or their alteration products) apparently has been incorporated into macromolecular organic matter, as revealed by hopanoids released from pyrolysates (see chapter 3.5, Figure C.1). A major part of BHPs probably have been degraded by intensive activity of microorganisms, eventually causing the major degradation of hopanoids, also reflected by the low $\mathrm{C}_{\text {org }}$ in the deeper part of the mat (1.2\%-1.47\%; Table 4.1a). Alternative source of hopanoids is new production of BHPs downwards in the mat. As reported by Blumenberg et al. (2013) about another mat on Kiritimati, BHPs could be more abundant in deeper layers. Such an additional input was accompanied by the slight co-occurring increase in bacterial FAs. However, the predominant source of hopanoids in the deeper mat is derived from defunctionalisation of BHPs rather than new production. This is also revealed by the constant steroids/hopanoids ratios downwards in the mat (Table C.3). Specifically, this ratio significantly dropped in the upper two layers, which resulted from the remarkable degradation of steroids occurred therein. Thereafter, the ratios showed constant low values in the deeper part of the mat, as a result of the consistent degradation of both steroids and hopanoids, and thus, no primarily additional inputs of hopanoids occurred in deeper layers. This is corroborated by the overall low $\mathrm{C}_{\text {org }}$ contents downwards in the mat, indicating no major production of bacteria-derived lipid biomarkers 
occurred therein. Further, the relative depth distribution of FAs and steroids is similar in the upper layers, as evident from fairly constant steroids/FAs ratios, suggesting they experienced similar preservation pathways. Below, in the deeper layer 5, steroids/FAs ratios markedly increased, possibly due to the production of $\mathrm{C}_{31}$-sterols derived from dinoflagellates resting cysts (Shen et al., 2019). In the bottom layer 6, the ratio decreased again, caused by the ongoing degradation of steroids.

In the carbonate-bound lipids, hopanoids were far less abundant compared to the free lipid fractions. Specifically, hopanoids increased in abundance until layer 3 and then decreased again. FAs showed similar trends with a maximum in layer 3 and decreasing concentrations in the deeper layers (Table C.4; Figure 4.7b). Unlike hopanoids and FAs, the total carbonatebound steroids showed overall low abundance through the mat. The high abundances of FAs and hopanoids in layer 3 co-occurs with the presence of large amounts of remains from filamentous microbes, diatoms and foraminifera, as well as the presence of large pores filled with residual OM (igires 4.5e-h, also see 4.1). Further, steroids/hopanoids ratios decreased in the upper layers (2-3), due to an increase in hopanoids in the mineral crust of layer 3 . This possibly also influenced the underlain layer 4 that induced large amounts of microorganisms thriving there, as the observed high abundance of hopanoids. In the lower layers 5 and 6 , steroids/hopanoids ratios showed a significant increase, inferred from the major degradation of hopanoids downwards in the mat. Steroids/FAs ratios had very low values through the mat profile. The lowest values were observed in layer 3, which contained the highest concentration of FAs. This coincides with the microscopy observation of abundant presence of remains of filamentous microbes, diatoms and foraminifera. In the deeper mat, these ratios slightly increased, due to the decrease in the abundance of FAs. As discussed above (‥3.1

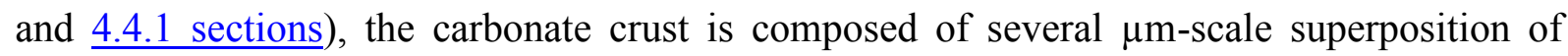
fibrous-radial botryoidal laminae, which indicate crust layer 3 was formed during episodic, repeated fast mineral precipitation probably only occurred during favorable moments. These episodes of fast mineralization result in the entrapment of microorganisms, and it also explains the more efficient inclusion of lipids within layer 3 as compared to the other mat layers. This phenomenon is evident from the sharp increase in bacteria-derived FAs and, to a lesser extent, hopanoids (Table C.4; Figure 4.7b).

Unlike hopanoids and FAs, eukaryote-derived steroids did not show an increase in abundance in layer 3, although plenty of steroids-producing diatom moulds were observed (Figure 4.5h). It is possibly resulted from the composition of diatom frustule that mainly 
consists of silicate, which can be easily dissolved in alkaline environments as the settings in the studied mat. Alternatively, it might be caused by a relatively fast (bacterial) degradation of organic matrix and/or diatom-derived EPS (function as protecting diatom frustules from dissolution), and thus accelerating the degradation processes and eventually not preserved over geological time (Lewin, 1961; Bidle and Azam, 1999). Consequently, the scenarios could be assumed that layer 3 experienced entirely distinct conditions deduced from large hydrological variations, which were probably no longer suitable for the accretion of microbial mat. Meanwhile, the distinct conditions might be in favour of the growth of diatom. However, these diatom-derived $\mathrm{OM}$ was rapidly altered/degraded/dissolved by microorganisms and replaced by carbonate minerals at the later stage of diagenesis, and this replacement process was more likely occurred during the formation of the carbonate crust. A further unique feature for the carbonate-bound lipids are the occurrence of $\alpha, \omega$-dicarboxylic acids ( $\alpha, \omega$-diacids). This is in concert with the report about the early Jurassic concretions and their immediate host rocks, published by Thiel and Hoppert. (2018). They stated remarkably more abundant dicarboxylic acids in concretions detected compared to the host rocks, suggesting an enrichment of preservation or selective accumulation mechanism for these compounds in the concretions (Thiel and Hoppert, 2018). Several works suggested that $\alpha, \omega$-diacids have multiple biological sources, e.g., higher plants (Kolattukudy, 1980), sea-grass (Volkman et al., 1980), and can also be derived from in situ formation (via terminal oxidation of monoacids or other aliphatic moieties such as $n$-alkanes; Ishiwatari and Hanya, 1975; Johns and Onder, 1975) and $\omega$-hydroxy acids (Cranwell, 1978; Eglinton, Hunneman and DouraghiZadeh, 1968). Moreover, in another recent study on Cretaceous hydrocarbon seep limestones, Smrzka et al. (2017) detected $\alpha, \omega$-diacids only after dissolution of the authigenic carbonate minerals, which might indicate an in-situ formation directly associated with carbonate precipitation, which is in agreement with the diacids only observed in the carbonate-bound lipids of the studied mat. Combined with the observed terrestrial plants-derived $\mathrm{C}_{29}$ sterols as well as $\mathrm{C}_{20}-\mathrm{C}_{28} \mathrm{FAs}$ in the studied mat, we therefore assume that these $\alpha, \omega$-diacids primarily originated from higher plant waxes and/or terminal oxidation of monoacids.

Consequently, lipid biomarkers (i.e., steroids, hopanoids and FAs, Figure 4.7a) experienced major degradation in the freely extractable lipids of the studied mat. This is in line with the previous report from the same mat in Kiritimati Lake 2 that described a decreased concentration of microbial FAs in the decalcified extraction residues (Blumenberg et al., 2015). However, the decreased hopanoids in the studied mat is in disagreement with the 
increased hopane/sterane ratios in the decalcified extraction residues of the deeper mat (Blumenberg et al., 2015), which might be interpreted as the extractable hopanoids were degraded during further burial of the mat, while the other part of hopanoids were sequestered into proto-kerogen (equal to "decalcified extraction residues" in this work), therefore better preserved in the geological record. Unlike the free lipids, carbonate-bound biomarkers behaved completely different, which shows a sharp increase in abundance of hopanoids and FAs occurred in layer 3, which was not analysed by Blumenberg et al. (2015), is interpreted here as being linked to the abundance of remains of filamentous microbes, diatoms and foraminifera entrapped in large pores of the carbonate crust of layer 3 (Figures 4.5e-h).

\subsubsection{Stable carbon isotope signatures for microbial lipids $\left(\delta^{13} C_{\text {lipid }}\right)$ and bulk carbonate $\left(\delta^{13} C_{\text {carb }}\right)$}

Highly enriched $\delta^{13} \mathrm{C}$ values (weighted average c. $-10 \%$ ) were observed for the short-chain FAs in the studied mat, clearly implying their carbon sources were autochthonous and derived from the hypersaline, $\mathrm{CO}_{2}$-limited ecosystem of Lake 2 (cf. Schouten et al., 2001). This ${ }^{13} \mathrm{C}$ enrichment in microbial lipids was consensus from a recent study concentrating on the same Lake 2 mat that showed high $\delta^{13} \mathrm{C}$ values for eukaryotic sterols from the top layer 1 (Shen et al., 2019). Further, the long-chain FAs were generally depleted (i.e., by weighted average 0.1$8.2 \%$ in this work) than the short-chain homologues, indicating partial contributions from terrestrial higher plants (Schouten et al., 2001).

For the hopanoids they showed lower $\delta^{13} \mathrm{C}$ values as compared to the other lipids, suggesting these hopanoids were partially originated from methanogens or anaerobic methane-oxidizing archaea (Pancost and Pagani, 2006). In addition, van der Meer et al. (1998) reported that isoprenoid lipids were 7 to $9 \%$ in ${ }^{13} \mathrm{C}$-depletion relative to the straightchain lipids, due to the utilization of the reversed tricarboxylic acid cycle. Apparently, the observed $\delta^{13} \mathrm{C}$ values of hopanoids (pentacyclic isoprenoids) in the studied mat are well in the range of that published isotope data of isoprenoids (van der Meer et al., 1998).

Throughout the mat profile, slightly lighter $\delta^{13} \mathrm{C}$ values were observed in the deeper, older growth phase of the mat (layers 5 and 6) than the topmost layer 1, suggesting a decrease in suppression effect caused by $\mathrm{CO}_{2}$-limitation of local Lake 2 ecosystem. This phenomenon was, to a greater extent, observed in the mineral crust of layer 3 that showed more ${ }^{13} \mathrm{C}$ depleted values. Furthermore, FAs and hydrocarbons (i.e., $\mathrm{C}_{17} n$-alkanes) showed more ${ }^{13} \mathrm{C}$ depletions in the mineral crust of layer 3 . This supports the idea that during the formation of 
layer 3, the lake has experienced periods with enhanced inputs of fresher or less saline groundwater. The reduced salinity caused changes in the mat biota, which is reflected by the microscope observations, the biomarker composition and the carbon isotope values.

The $\Delta \delta^{13} \mathrm{C}$ between FA and bulk carbonate was given in Table 4.3, exhibited from -11.8 to $-21.8 \%$ for $\Delta \delta^{13} \mathrm{C}_{\text {(FA-carbfine) }}$ and $-14.3-21.8 \%$ for $\Delta \delta^{13} \mathrm{C}_{\text {(FA-carbooid) }}$, respectively, which were in the same range of $\Delta \delta^{13} \mathrm{C}_{\text {(FA-substrate) }}$ as reported by (Londry et al., 2004).

No consistent trend of the FAs isotopes observed between free and carbonate-bound lipid fractions. For instance, part of the isotopic results (e.g. $\mathrm{C}_{19: 1}$ ) showed ${ }^{13} \mathrm{C}$-enriched signatures for carbonate-bound FAs as compared to freely extractable counterparts (see Table 4.2), which reconcile with the previous studies that reported similar observation (Craig et al., 2004; O'Reilly et al., 2017; Summons et al., 2013). Some carbonate-bound FAs (e.g. $C_{18: 1}$ ) have similar $\delta^{13} \mathrm{C}$ values as they showed in the free lipids, which is congruent with a recent investigation published by Smrzka et al. (2017). The other FAs (e.g. $C_{16}$ ) showed more depletion in ${ }^{13} \mathrm{C}$ contents in the carbonate-bound fractions than the free lipids. Thiel et al. (1999) reported isotopically lighter $\delta^{13} \mathrm{C}$ values of carbonate-bound hydrocarbons than those in free lipid pools, which, in their study, might be caused by the anaerobic methane-oxidation. This $\delta^{13} \mathrm{C}$ values pattern is in agreement with the isotope distributions for the observed cases such as $\mathrm{C}_{16} \mathrm{FAs}$ in the studied mat, but the potential explanation is unlikely as reported by Thiel et al. (1999). In addition, Summons et al. (2013) reported carbon isotope data of oolites from hypersaline Hamelin Pool, and demonstrated that isotopic signatures of the $\mathrm{OM}$ in the carbonate matrix differ from the freely extractable lipids, which might be related to some fractionation process that mediate the entrapment of organics in the carbonate. Of the observed $\delta^{13} \mathrm{C}$ values for FAs in the studied mat, the mechanisms for these variable ${ }^{13} \mathrm{C}$ contents of FAs (without consistent trend) between free and carbonate-bound lipids are yet unclear. It might be associated with different environmental settings and diverse physiology of microorganisms.

Bulk carbonate of Lake 2 mat showed positive $\delta^{13} \mathrm{C}$ signatures, which is similar to the carbonate isotope data up to $+6.3 \%$ reported by Arp et al. (2012). Among the two types of carbonate mineral, a shift towards higher $\delta^{13} \mathrm{C}$ values for the large ooids than for the fine particles were observed. These discrepancies might be resulted from distinct EPS (i.e., carry originally disparate ${ }^{13} \mathrm{C}$ signals) producing different size of carbonate minerals, or diverse metabolisms of microorganisms generating/mediating the variations of ${ }^{13} \mathrm{C}$ contents. 


\subsection{Conclusion}

The processes of microbial mat mineralization and the preservation pathways of $\mathrm{OM}$ in the resulting microbialites were investigated in different layers of a c. 1500 yrs hypersaline microbial mat from Kiritimati island. Two major growth phases are observed within the studied mat and they are separated by a thin, distinctive mineral crust. Our analysis reveals two distinct calcification modes in this single mat, one exhibit in both accretion phases (the main microbialite), the other only showing in the thin mineral crust. Further, we notice the primary $\mathrm{OM}$ in these deposits was preserved in two very different ways. Firstly, in the main microbialite, those minerals were formed due to the degradation of EPS that initially suppress the formation of carbonate. During further growth of the mat, OM was gradually degraded, as reflected by a decline in total organic carbon and bacteria-derived hopanoids and fatty acids in the deeper parts of the mat. Contrarily, petrographic features suggest that the carbonate crust at the boundary horizon is consisted of $\mu \mathrm{m}$-scale superposition of radial-fibrous botryoidal laminae, indicating the precipitation was episodic, occurring at times of favorable environmental conditions and this entire mineral crust was calcified due to a very fast collapse of the EPS inhibition function. This hydro-chemically driven, event-like mode of calcification was accompanied by a significant biotic change, as inferred from abundant filamentous microbes and diatoms and the depleted $\delta^{13} \mathrm{C}$ signatures for lipid biomarkers observed within the thin mineral crust. It also caused a fast and efficient inclusion of lipid biomarkers, as reflected by a remarkable increase in the abundances of fatty acids and, to a lesser extent, hopanoids. These results suggest that the episodes of hydrological changes may have resulted in a fast entrapment of $\mathrm{OM}$ in microbial mats and an enrichment of its preservation within distinctive mineral precipitates. Such rapidly formed precipitates might have preserved OM better than the normal mineralization and hence represent excellent targets for the search of authentic $\mathrm{OM}$ in the ancient microbialites.

\section{Acknowledgements}

We thank Prof. Dr. Gernot Arp for providing helpful information and thoughtful comments. Dr. Andreas Reimer, Dr. Jens. Dyckmans, Wolfgang Dröse, Birgit Röring, and Dorothea Hause-Reitner are acknowledged for technical support and laboratory assistance. The German Research Foundation (DFG, project Re 665/18-2 and Research Unit 571 "Geobiology of Organo- and Biofilms") is kindly acknowledged for financial support. 


\section{References}

Allwood, A. C., Walter, M. R., Kamber, B. S., Marshall, C. P., and Burch, I. W. (2006). Stromatolite reef from the Early Archaean era of Australia. Nature, 441, 714-718.

Anhalt, J. P. and Fenselau, C. (1975). Identification of bacteria using mass spectrometry. Anal. Chem. 47, 219-225.

Arp, G., Helms, G., Karlinska, K., Schumann, G., Reimer, A., Reitner, J., and Trichet, J. (2012). Photosynthesis versus Exopolymer Degradation in the Formation of Microbialites on the Atoll of Kiritimati, Republic of Kiribati, Central Pacific. Geomicrobiology Journal, $29,29-65$.

Arp, G., Hofmann, J., and Reitner, J. (1998). Microbial Fabric Formation in Spring Mounds ("Microbialites") of Alkaline Salt Lakes in the Badain Jaran Sand Sea, PR China, PALAIOS, 13, 581-592.

Arp, G., Reimer, A., and Reitner, J. (1999a). Calcification in cyanobacterial biofilms of alkaline salt lakes. European Journal of Phycology, 34, 393-403.

Arp, G., Reimer, A., and Reitner, J. (2001). Phtosynthesis-induced biofilm calcification and calcium concentrations in Phanerozoic oceans. Science, 292, 1701-1704.

Arp, G., Reimer, A., and Reitner, J. (2003). Microbialite Formation in Seawater of Increased Alkalinity, Satonda Crater Lake, Indonesia. Journal of Sedimentary Research, 73, 105-127.

Arp, G., Thiel, V., Reimer, A., Michaelis, W., and Reitner, J. (1999b). Biofilm exopolymers control microbialite formation at thermal springs discharging into the alkaline Pyramid Lake, Nevada, USA. Sedimentary Geology, 126, 159-176.

Awramik, S. M. and Vanyo, J. P. (1986). Heliotropism in modern stromatolites. Science, 231, 1279-1281.

Benzerara, K., Menguy, N., López-García, P., Yoon, T.-H., Kazmierczak, J., Tyliszczak, T., Guyot, F., and Brown, G. E. (2006). Nanoscale detection of organic signatures in carbonate microbialites. Proc Natl Acad Sci USA, 103, 9440-9445.

Bidle, K. D. and Azam, F. (1999). Accelerated dissolution of diatom silica by marine bacterial assemblages. Nature, 397, 508-512.

Blumenberg, M., Arp, G., Reitner, J., Schneider, D., Daniel, R. and Thiel, V. (2013). Bacteriohopanepolyols in a stratified cyanobacterial mat from Kiritimati (Christmas Island, Kiribati). Organic Geochemistry 55, 55-62.

Blumenberg, M., Thiel, V., and Reitner, J. (2015). Organic matter preservation in the carbonate matrix of a recent microbial mat - Is there a 'mat seal effect'? Organic Geochemistry, 87, 25-34.

Bolhuis, H., Fillinger, L., and Stal, L. J. (2013). Coastal microbial mat diversity along a natural salinity gradient. PLoS ONE, 8, 1-12. 
Burne, R. V. and Moore, L. S. (1987). Microbialites: organosedimentary deposits of benthic microbial communities. PALAIOS, 2, 241-254.

Camoin, G., Casanova, J., Rouchy, J.-M., Blanc-Valleron, M.-M., and Deconinck, J.-F. (1997). Environmental controls on perennial and ephemeral carbonate lakes:vthe central palaeo-Andean Basin of Bolivia during Late Cretaceous to early Tertiary times.

Sedimentary Geology, 113, 1-26.

Couradeau, E., Benzerara, K., Gerard, E., Moreira, D., Bernard, S., Brown, G. E., and LopezGarcia, P. (2012). An early-branching microbialite cyanobacterium forms intracellular carbonates. Science, 336, 459-462.

Craig, O. E., Love, G. D., Isaksson, S., Taylor, G., and Snape, C. E. (2004). Stable carbon isotopic characterisation of free and bound lipid constituents of archaeological ceramic vessels released by solvent extraction, alkaline hydrolysis and catalytic hydropyrolysis. Journal of Analytical and Applied Pyrolysis, 71, 613-634.

Cranwell P. A. (1978). Extractable and bound lipid components in a freshwater sediment. Geochimica et Cosmochimica Acta 42, 1523-1532.

Défarge, C., Trichet, J., Jaunet, A.-M., Robert, M., Tribble, J., and Sansone, F. J. (1996). Texture of microbial sediments revealed by cryo-scanning electron microscopy. SEPM JSR, $66,935-947$.

Dupraz, C., Fowler, A., Tobias, C., and Visscher, P. T. (2013). Stromatolitic knobs in Storr's Lake (San Salvador, Bahamas): A model system for formation and alteration of laminae. Geobiology, 11, 527-548.

Dupraz, C., Reid, R. P., Braissant, O., Decho, A. W., Norman, R. S., and Visscher, P. T. (2009). Processes of carbonate precipitation in modern microbial mats. Earth-Science Reviews, 96, 141-162.

Dupraz, C., Reid, R. P., and Visscher, P. T. (2011). Microbialites, Modern. Encyclopedia, 617-635.

Dupraz, C. and Visscher, P. T. (2005). Microbial lithification in marine stromatolites and hypersaline mats. Trends in microbiology, 13, 429-438.

Eglinton, G., Hunneman, D. H. and Douraghi-Zadeh, K. (1968). Gas chromatographic-mass spectrometric studies of long chain hydroxy acids-II: The hydroxy acids and fatty acids of a 5000-year-old lacustrine sediment. Tetrahedron 24, 5929-5941.

Freytet, P. and Plet, A. (1996). Modern freshwater microbial carbonates: The Phormidium stromatolites (tufa-travertine) of southeastern Burgundy (Paris Basin, France). Facies, 34, 219-238.

Grotzinger, J. P. and Knoll, A. H. (1999). Stromatolites in Precambrian carbonates: evolutionary mileposts or environmental dipsticks? Annual review of earth and planetary sciences, 27, 313-358.

Hofmann, H. J., Grey, K., Hickman, A. H., and Thorpe, R. I. (1999). Origin of 3.45 Ga coniform stromatolites in Warrawoona Group, Western Australia. Geological Society of America Bulletin, 111, 1256-1262. 
Ionescu, D., Spitzer, S., Reimer, A., Schneider, D., Daniel, R., Reitner, J., de Beer, D., and Arp, G. (2015). Calcium dynamics in microbialite-forming exopolymer-rich mats on the atoll of Kiritimati, Republic of Kiribati, Central Pacific. Geobiology, 13, 170-180.

Ishiwatari, R. and Hanya, T. (1975). Organic geochemistry of a 200-meter core sample from Lake Biwa. II Vertical distribution of Mono- and Di-carboxylic acids and polynuclear aromatic hydrocarbons. Proceedings of the Japan Academy, 51, 436-441.

Johns, R. B. and Onder, O. M. (1975). Biological diagenesis: dicarboxylic acids in recent sediments. Geochimica et Cosmochimica Acta, 39, 129-136.

Kates, M. (1964). Bacterial Lipids** ${ }^{*}$ Issued as N.R.C. No. 8043. In Bacterial Lipids. Elsevier, pp. 17-90.

Kolattukudy, P. E. (1980). Biopolyester membranes of plants: cutin and suberin. Science, 208, 990-1000.

Léveillé, R. J., Fyfe, W. S., and Longstaffe, F. J. (2000). Geomicrobiology of carbonatesilicate microbialites from Hawaiian basaltic sea caves. Chemical Geology, 169, 339-355.

Lewin, J. C. (1961). The dissolution of silica from diatom walls. Geochimica et Cosmochimica Acta, 21, 182-198.

Londry, K. L., Jahnke, L. L., and Des Marais, D. J. (2004). Stable Carbon Isotope Ratios of Lipid Biomarkers of Sulfate-Reducing Bacteria. Applied and Environmental Microbiology, 70, 745-751.

Mikutta, R., Kleber, M., Kaiser, K., and Jahn, R. (2005). Review: Organic matter removal from soils using hydrogen peroxide, sodium hypochlorite, and disodium peroxodisulfate. Soil Science Society of America, 69, 120-135.

Nielsen, P. H., Jahn, A., and Palmgren, R. (1997). Conceptual model for production and composition of exopolymers in biofilms. Water Science and Technology, 36, 11-19.

O'Reilly, S. S., Mariotti, G., Winter, A. R., Newman, S. A., Matys, E. D., McDermott, F., Pruss, S. B., Bosak, T., Summons, R. E., and Klepac-Ceraj, V. (2017). Molecular biosignatures reveal common benthic microbial sources of organic matter in ooids and grapestones from Pigeon Cay, The Bahamas. Geobiology, 15, 112-130.

Pancost, R. and Pagani, M. (2006). Controls on the carbon isotopic compositions of lipids in marine environments. The handbook of Environmental Chemistry, 2, 209-249.

Reitner, J. (1993). Modern cryptic microbialite/metazoan facies from Lizard Island (Great Barrier Reef, Australia) formation and concepts. Facies, 29, 3-40.

Reitner, J., Gautret, P., Marin, F., and Neuweiler, F. (1995). Automicrites in a modern marine microbialites. Formation model via organic matrices (Lizard Island, Great Barrier Reef, Australia). Bull. Inst. Océan. Monaco, 14, 237-263.

Riding, R. (2011). The Nature of Stromatolites: 3,500 Million Years of History and a Century of Research, in: Advances in Stromatolite Geobiology, Reitner, J., Quéric, N.-V., Arp, G. (Eds.), Lecture Notes in Earth Sciences, Springer Berlin Heidelberg, Berlin, Heidelberg, $29-74$. 
Rohmer, M., Bouvier-Nave, P. and Ourisson, G. (1984). Distribution of hopanoid triterpenes in prokaryotes. Journal of General Microbiology 130, 1137-1150.

Saenger, C., Miller, M., Smittenberg, R. H., and Sachs, J. P. (2006). A physico-chemical survey of inland lakes and saline ponds: Christmas Island (Kiritimati) and Washington (Teraina) Islands, Republic of Kiribati. Saline systems, 2, 1-15.

Scherf, A.-K. and Rullkötter, J. (2009). Biogeochemistry of high salinity microbial mats Part 1: Lipid composition of microbial mats across intertidal flats of Abu Dhabi, United Arab Emirates. Organic Geochemistry, 40, 1018-1028.

Schouten, S., Hartgers, W. A., Lòpez, J. F., Grimalt, J. O., and Sinninghe Damsté, J. (2001). A molecular isotopic study of ${ }^{13} \mathrm{C}$-enriched organic matter in evaporitic deposits: recognition of $\mathrm{CO}_{2}$-limited ecosystems. Organic Geochemistry, 32, 277-286.

Shen, Y., Thiel, V., Duda, J.-P., and Reitner, J. (2018). Tracing the fate of steroids through a hypersaline microbial mat (Kiritimati, Kiribati/Central Pacific). Geobiology, 16, 307-318.

Shen, Y., Thiel, V., Suarez-Gonzalez, P., Rampen, S. W., and Reitner, J. (2019). Sterol preservation in hypersaline microbial mats, Biogeosciences Discuss., 1-28.

Shiea, J., Brassel, S. C., and Ward, D. M. (1991). Comparative analysis of extractable lipids in hot spring microbial mats and their component photosynthetic bacteria. Organic Geochemistry, 17, 309-319.

Słowakiewicz, M., Whitaker, F., Thomas, L., Tucker, M. E., Zheng, Y., Gedl, P., and Pancost, R. D. (2016). Biogeochemistry of intertidal microbial mats from Qatar: New insights from organic matter characterization. Organic Geochemistry, 102, 14-29.

Smrzka, D., Zwicker, J., Kolonic, S., Birgel, D., Little, C. T.S., Marzouk, A. M., Chellai, E. H., Wagner, T., and Peckmann, J. (2017). Methane seepage in a Cretaceous greenhouse world recorded by an unusual carbonate deposit from the Tarfaya Basin, Morocco. Depositional Rec, 3, 4-37.

Summons, R. E., Bird, L. R., Gillespie, A. L., Pruss, S. B., Roberts, M., and Sessions, A. L. (2013). Lipid biomarkers in ooids from different locations and ages: evidence for a common bacterial flora. Geobiology, 11, 420-436.

Thiel, V. and Hoppert, M. (2018). Fatty acids and other biomarkers in two Early Jurassic concretions and their immediate host rocks (Lias $\delta$, Buttenheim clay pit, Bavaria, Germany). Organic Geochemistry, 120, 42-55.

Thiel, V., Peckmann, J., Seifert, R., Wehrung, P., Reitner, J., and Michaelis, W. (1999). Highly isotopically depleted isoprenoids: Molecular markers for ancient methane venting. Geochimica et Cosmochimica Acta, 63, 3959-3966.

Trichet, J., Défarge, C., Tribble, J., Tribble, G., and Sansone, F. (2001). Christmas Island lagoonal lakes, models for the deposition of carbonate-evaporite-organic laminated sediments. Sedimentary Geology, 140, 177-189.

van der Meer, M. (2002). Structure and isotopic composition of bacterial lipids: Insights into distribution and carbon acquisition mechanisms of bacteria in hot spring microbial mats, $\mathrm{PhD}$ thesis. Universitaet Utrecht, 1-91. 
van der Meer, M. T. J., Schouten, S., and Sinninghe Damsté, J. S. (1998). The effect of the reversed tricarboxylic acid cycle on the ${ }^{13} \mathrm{C}$ contents of bacterial lipids. Organic Geochemistry, 28, 527-533.

van Gemerden, H. (1993). Microbial mats: A joint venture. Marine Geology, 113, 3-25.

Volkman, J. K., Johns, R. B., Gillan, F. T., Perry, G. J., Bavor, H. J., and JR (1980). Microbial lipids of an intertidal sediment-I.Fatty acids and hydrocarbons. Geochimica et Cosmochimica Acta, 44, 1133-1143.

Walter, M. R. (1976). Stromatolites, Developments in Sedimentology, 20. Elsevier Scientific Pub. Co, Amsterdam, New York. 


\section{-Chapter 5-}

\section{$\underline{\text { Summary and conclusions }}$}

This thesis integrated a series of experimental works, which were designed to aim at 1) assessing the fate of total extractable steroids in microbial mats; 2) differentiating the preservation pathways of sterols between freely extractable lipids, carbonate-bound lipids and the non-extractable residues, and testing if calcification within microbial mats may function as a preservation mechanism for these biomarkers; 3) examining the taphonomy of $\mathrm{OM}$ and microfacies in microbial mats, and providing reference data for the relations between the preservation of $\mathrm{OM}$ and the associated mineralization modes.

In the first study, a c. 1200 years old microbial mat from hypersaline Lake 22 of Kiritimati (Kiribati, Central Pacific) was investigated to analyze the fate of steroids (Chapter 2). This mat was divided into different layers, and the steroids inventory in the total lipid extracts was assessed and quantified in each mat layer. It was demonstrated that progressive microbial alteration of primary sterols occurred within the mat, which was reflected by the increases in stanols and sterenes vs. $\Delta^{5}$-stenols, as well as the presence of thiosteranes in certain mat layers. The summed concentrations of total steroids were consistently abundant throughout the mat, and did not show any systematic decrease with depth, hence the result argues against "mat-seal effect".

The second study examined the taphonomic pathways of eukaryotic sterols, differentiated in freely extractable and carbonate-bound lipids and insoluble organic matter, in a recent hypersaline microbial mat (Lake 2, Kiritimati; Chapter 3). High $\delta^{13} \mathrm{C}$ values of $\mathrm{C}_{31}$-sterols and fatty acids indicate an autochthonous origin for these lipids. A significant drop in total sterols was observed, up to $98 \%$ in the deeper part of the mat, suggesting a major degradation of these compounds. Further, carbonate-bound sterols generally appeared in low abundances, indicating that incorporation into the mineral matrix did not play a major role in the preservation of sterols in this mat. Likewise, steroids were not sequestered into insoluble organic matter. Therefore, the results from this work support the hypothesis of "mat-seal effect". Interstingly, the distribution patterns of the steroids from this Lake 2 mat are markedly different from the previous findings from the Lake 22 mat, where there was no evidence for such a "mat-seal effect". The potential mechanisms which might have caused the 
distinct behavior of sterols could be differences in salinity and/or temporal subaerial exposure in these two different lake ecosystems, and hence contrasting sterol degradation patterns may be expected in response to environmental conditions, as showed by these particular cases.

As for the third study, analysis of lipid biomarkers combined with petrographic and histologic investigations were used in a depth profile of a recent calcifying mat ( 1500 years) from hypersaline Lake 2 in Kiritimati (the same mat as investigated in the second study; Chapter 4). This work aims at a better understanding of the processes that lead to mineralization of a microbial mat and the preservation of organic matter in the resulting microbialites. The analysis revealed two major phases of mat development, separated by a distinctive mineral crust, which contrasts with the common mineral precipitation (i.e., mainly controlled by the degradation of EPS, exopolymeric substances) observed in the two accretion phases. The primary organic matter in these deposits was preserved in two different ways: one observed in both accretion phases, and the other occurring only in the thin mineral crust that separates them. To our best knowledge, this is the first time that significantly different organic matter preservation pathways are observed within a single microbial mat. In addition, the ${ }^{14} \mathrm{C}$ dates of the mat illustrate that preservation of lipids may have been strongly controlled by mineralization processes. Fast mineral precipitation driven by environmental changes, resulting in a rapid and efficient inclusion of lipid biomarkers, as reflected by a remarkable increase in the abundance of microbial lipid signatures within the crust. Meanwhile, this hydrologically-driven mineralization was accompanied by a significant biotic change, as inferred from abundant filamentous microbes and diatoms therein. Consequently, such rapidly formed precipitates might have preserved organic matter much better than the normal mineralization and hence represent excellent targets for the search of authentic organic matter in ancient microbialites.

In conclusion, this thesis demonstrates that the preservation of steroids in microbial mats may not be exclusively controlled by heterotrophic degradation, but rather depends on a complex interplay of sedimentary and taphonomic processes. It may be also influenced by multiple biotic and abiotic factors including salinity and periods of subaerial exposure, which might cause the occurrence of "mat-seal effect" or not. Therefore, caution must be taken when analyzing sterols distribution patterns in modern and ancient fossil microbialites. Moreover, thorough consideration of mineralization processes should be particularly exercised in the future works if investigating microbial lipids in fossil microbial mats, in order to obtain comprehensive interpretation of organic biosignatures encased therein. 


\section{-Chapter 6-}

\section{$\underline{\text { Outlook }}$}

Further works associated with this thesis would include the evaluation of pyrolysis results from the non-extractable organic matter (partially presented in Appendix A and $\underline{B}$ ). Currently, only steroids and hopanoids were analyzed in the extraction residues from the studied microbial mats. The other kerogen-bound compounds such as furan, indole and levoglucosan were not investigated yet, since some of them have been demonstrated as indicative of proteins and sugars. Obtaining the detailed information in the kerogen fraction will allow presenting a complementary picture of organic matter preserved in microbial mats. In addition to the kerogen, pyrolyzing the original mat samples could be another work in the future. This would enable the comparison of organic compounds between the original bulk mat and extraction residues.

Experimental results presented in this thesis mainly concentrated on the preservation pathways of eukaryote-derived steroids and microbial-derived hopanoids and fatty acids

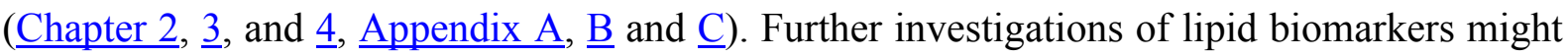
extend to the evaluation of intact bacteriohopanepolyols (BHP) and their related products such as acetyl derivative of anhydrobacteriohopanetetrol, aromatized hopane glucosamine, and hopane series containing thiophene rings.

The hypothesis of mat-seal effect was tested in hypersaline lake ecosystems on the atoll of Kiritimati. More hypersaline mats on the atoll might be examined to demonstrate whether ultrasalinity favor the preservation of steroids during burial processes. Further works could also encompass the low saline and brackish lakes on Kiritimati, to see if the taphonomy of organic matter differs from those observed in high salinity settings, and to get a more general idea about how the preservation of lipid biomarkers responds to different lake environmental conditions within the same general setting.

In addition to the Kiritimati atoll environments, more environmental settings, such as freshwater, hot springs and methane seeps (in particular, those that are similar to Proterozoic marine environments), could be involved in future research steps. These investigations would 
provide further understanding of the preservation of organic compounds in fossil microbial mats, through the study of varied modern analogues.

Finally, phylogenetic analysis (i.e., DNA extraction, PCR, pure culture) could be conducted to get an overview of taxonomic groups that lived in the mats. In combination with biogeochemical methods, it would provide more comprehensive results with respect to the biological precursors of lipid biomarkers and source organisms. 


\section{$\underline{\text { Appendix A }}$}

\section{Supplementary material}

Tracing the fate of steroids through a hypersaline microbial mat (Kiritimati, Kiribati/Central Pacific)

Table A.1: Concentrations of major fatty acids (FAs) and hopanoids ( $\beta \beta$-bishomohopanoic acid, $\beta \beta$ bishomohopan-32-ol and $\alpha \beta$-trishomohopan-32-ol) in the microbial mat layers ( $\mu \mathrm{g} / \mathrm{g}$ dry mat).

\begin{tabular}{|c|c|c|c|c|c|c|}
\hline Compound & 1 & 2 & 3 & 4 & 5 & 6 \\
\hline FAs & $\mu \mathrm{g} / \mathrm{g}$ & $\mu \mathrm{g} / \mathrm{g}$ & $\mu \mathrm{g} / \mathrm{g}$ & $\mu \mathrm{g} / \mathrm{g}$ & $\mu \mathrm{g} / \mathrm{g}$ & $\mu \mathrm{g} / \mathrm{g}$ \\
\hline $14: 0$ & 4.1 & 9.7 & 2.3 & 3.0 & 6.5 & 4.3 \\
\hline$i-15: 0$ & 11.0 & 25.5 & 4.8 & 4.7 & 8.5 & 7.9 \\
\hline$a i-15: 0$ & 5.1 & 12.3 & 3.1 & 3.1 & 3.6 & 3.9 \\
\hline 15:0 & 3.6 & 10.5 & 1.7 & 1.6 & 3.9 & 3.5 \\
\hline$i-16: 0$ & 19.5 & 37.6 & 5.2 & 5.4 & 5.7 & 5.6 \\
\hline $16: 0$ & 29.5 & 60.3 & 18.3 & 17.9 & 42.5 & 28.5 \\
\hline$i-17: 0$ & 6.0 & 16.8 & 4.7 & 4.4 & 7.9 & 9.0 \\
\hline$a i-17: 0$ & 7.3 & 17.6 & 3.3 & 3.2 & 5.4 & 5.8 \\
\hline $17: 0$ & 6.3 & 11.5 & 1.7 & 1.5 & 8.0 & 3.5 \\
\hline$\omega$-cyclohexyl-17:0 & 2.5 & 5.2 & 2.9 & 1.0 & 1.9 & 2.4 \\
\hline 18:1 (mainly $\omega 7 c$ and $\omega 9 c$ ) & 13.7 & 28.3 & 8.5 & 4.7 & 10.7 & 10.4 \\
\hline $18: 0$ & 23.0 & 10.2 & 10.1 & 9.0 & 19.0 & 20.7 \\
\hline 9,10-cyclopropyl-19:0 & 30.4 & 65.6 & 12.4 & 10.3 & 22.6 & 20.9 \\
\hline $20: 0$ & 4.3 & 6.0 & 2.4 & 2.6 & 4.6 & 4.5 \\
\hline $22: 0$ & 3.7 & 5.0 & 2.0 & 2.1 & 4.8 & 5.1 \\
\hline $24: 0$ & 9.0 & 16.5 & 7.6 & 6.5 & 15.3 & 15.4 \\
\hline $26: 0$ & 4.1 & 10.9 & 8.2 & 6.0 & 9.1 & 6.7 \\
\hline 28:0 & 3.4 & 7.2 & 4.4 & 4.8 & 6.3 & 6.2 \\
\hline $30: 0$ & 2.1 & 6.5 & 5.7 & 4.3 & 6.7 & 8.4 \\
\hline \multicolumn{7}{|l|}{ Hopanoids } \\
\hline$\beta \beta$-bishomohopanoic acid & 59.2 & 97.5 & 91.0 & 83.1 & 180.9 & 216.2 \\
\hline$\beta \beta$-bishomohopanol & 5.5 & 12.3 & 8.5 & 9.0 & 10.1 & 12.0 \\
\hline$\alpha \beta$-trishomohopanol & 12.8 & 14.3 & 42.0 & 40.8 & 79.3 & 33.6 \\
\hline
\end{tabular}


Table A.2: Concentrations of summed major hopanoids ( $\beta \beta$-bishomohopanoic acid, $\beta \beta$-bishomohopan-32ol and $\alpha \beta$-trishomohopan-32-ol), fatty acids (FAs) and steroids ( $\mu \mathrm{g} / \mathrm{g}$ dry mat) as well as steroids/hopanoids and steroids/FAs ratios in the microbial mat layers.

\begin{tabular}{|c|c|c|c|c|c|}
\hline Layers & Hopanoids & FAs & Steroids & $\begin{array}{c}\text { Steroids*/ } \\
\text { Hopanoids }\end{array}$ & Steroids*/FAs \\
\hline 1 & 77.5 & 188.6 & 54.3 & 0.76 & 0.31 \\
\hline 2 & 124.1 & 363.2 & 125.6 & 1.03 & 0.35 \\
\hline 3 & 141.5 & 109.3 & 49.1 & 0.37 & 0.48 \\
\hline 4 & 132.9 & 96.1 & 68.7 & 0.56 & 0.77 \\
\hline 5 & 270.3 & 193.0 & 110.5 & 0.43 & 0.60 \\
\hline 6 & 261.8 & 172.7 & 75.4 & 0.32 & 0.49 \\
\hline
\end{tabular}

*including dinosterol 


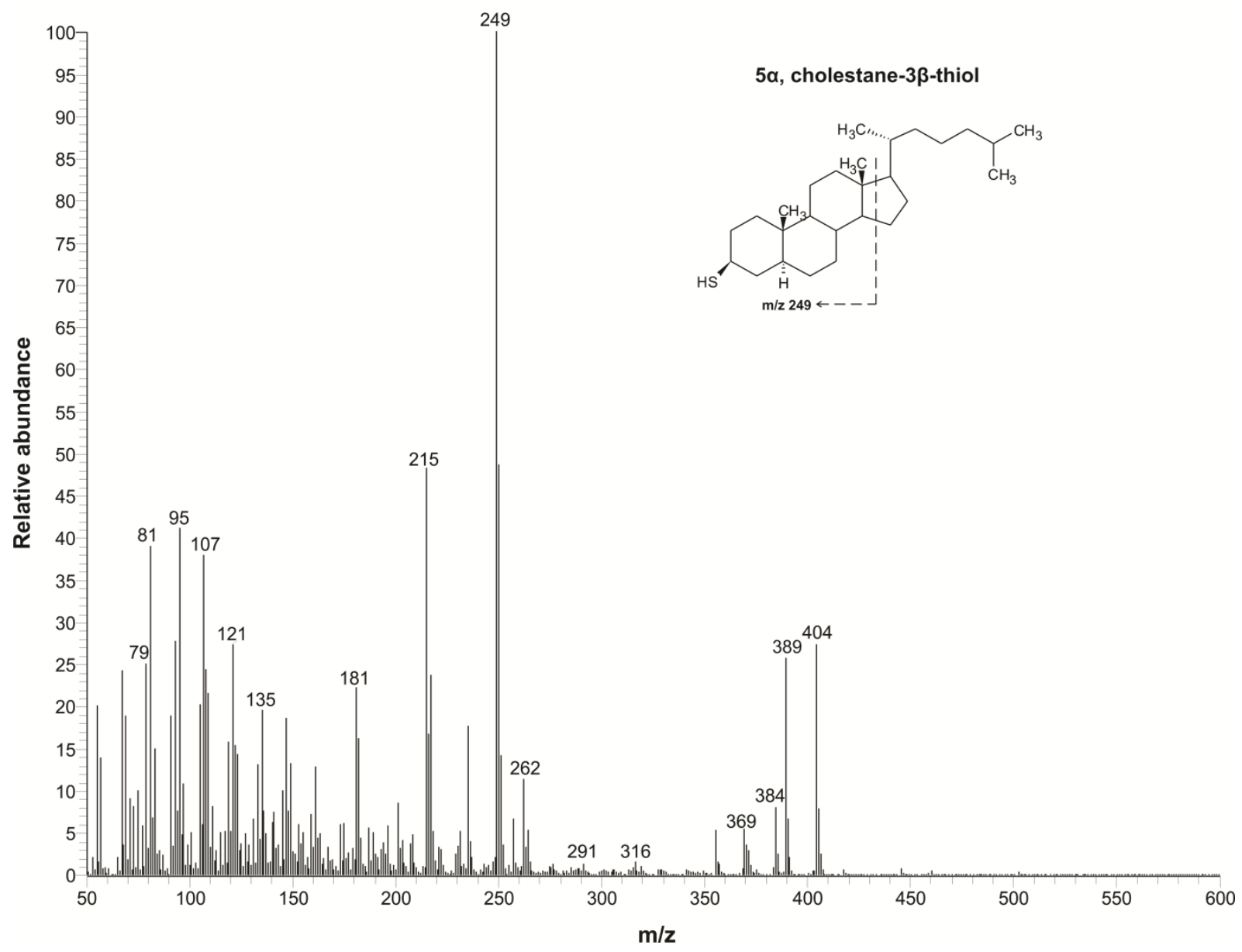

Figure A.1: Mass spectrum of the $\mathrm{C}_{27}$ thiosterane ( $5 \alpha$-cholestane- $3 \beta$-thiol) observed in the microbial mat layer 5 . 


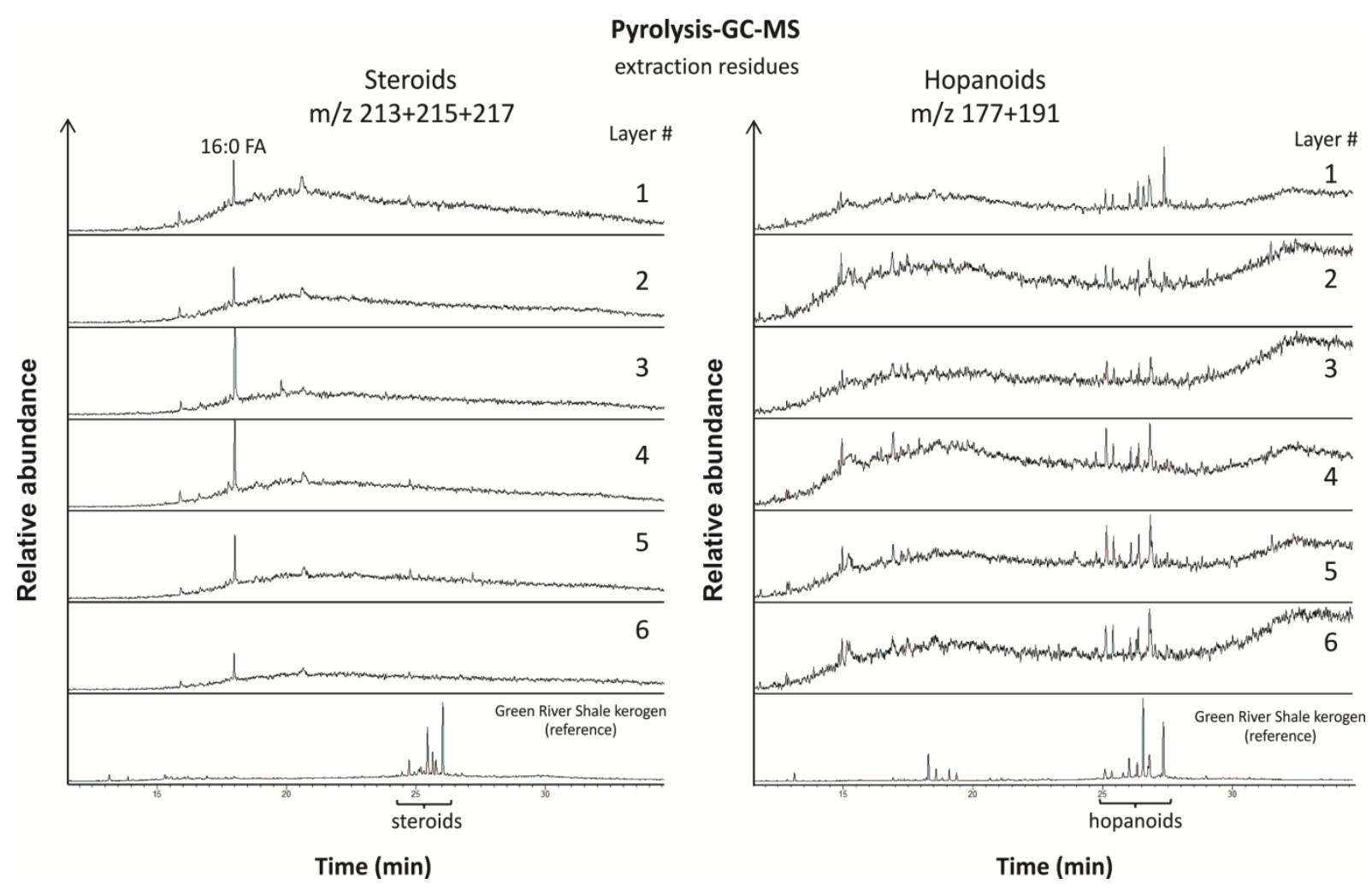

Figure A.2: Summed Pyrolysis-GC-MS chromatograms of steroids $(\mathrm{m} / \mathrm{z} 213+215+217)$ and hopanoids $(\mathrm{m} / \mathrm{z}$ 177+191) from microbial mat extraction residues (Eocene Green River Shale for reference). Please note that there are no detectable amounts of steroids in any of the mat layers, whereas hopanoids are always present. 


\section{$\underline{\text { Appendix B }}$}

\section{Supplementary material}

\section{Sterol preservation in hypersaline microbial mats}
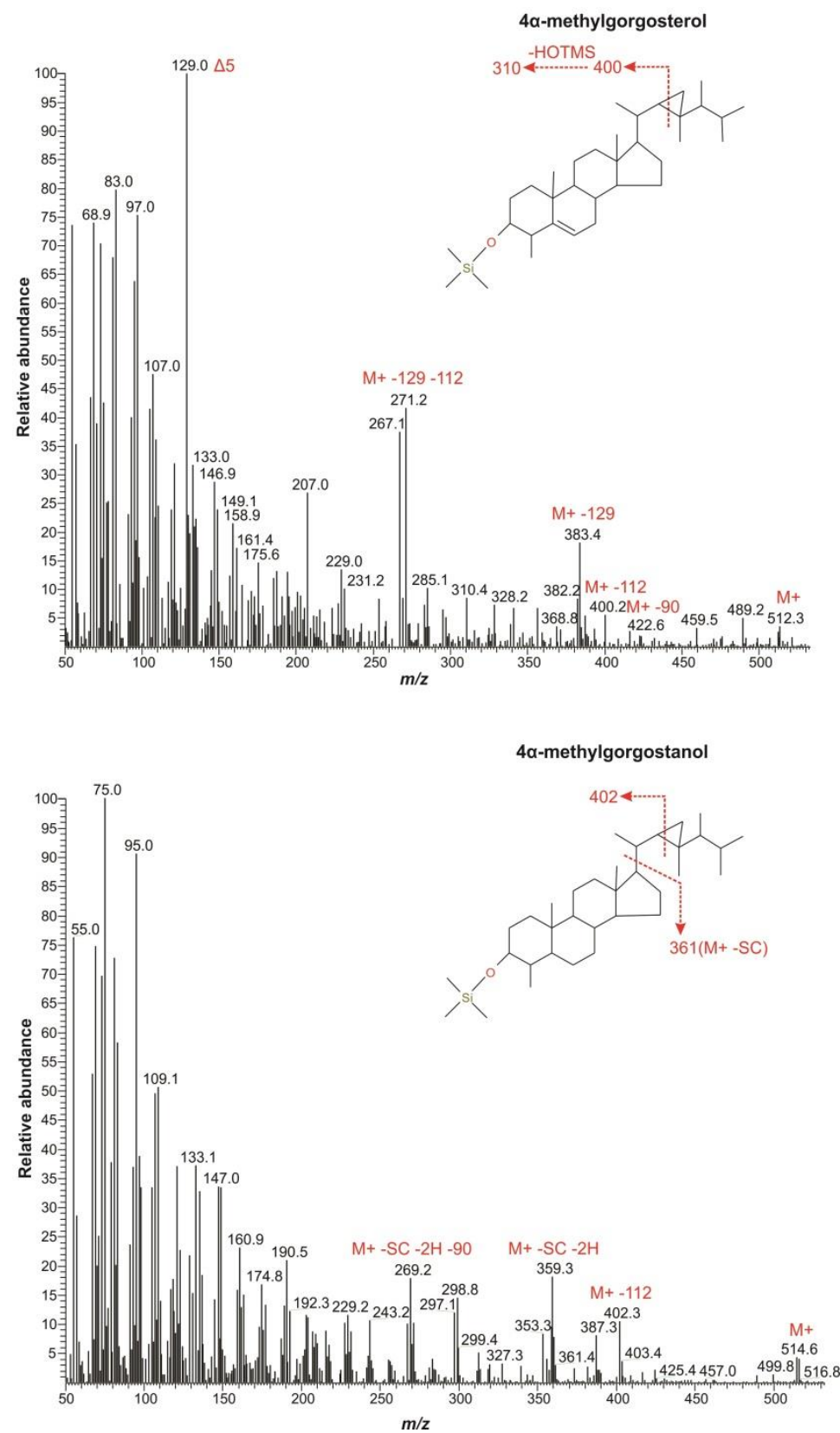

Figure B.1: Mass spectra of 22,23-methylene-4 $\alpha, 23,24$-trimethylcholest-5-en-3 $\beta$ ol (4 $\alpha$-methylgorgosterol) and 22,23-methylene-4 $\alpha, 23,24$-trimethylcholestan-3 $\beta$-ol (4 $\alpha$-methylgorgostanol) observed in the studiedmicrobial mat (Atwood et al., 2014; Houle et al., In Press). 


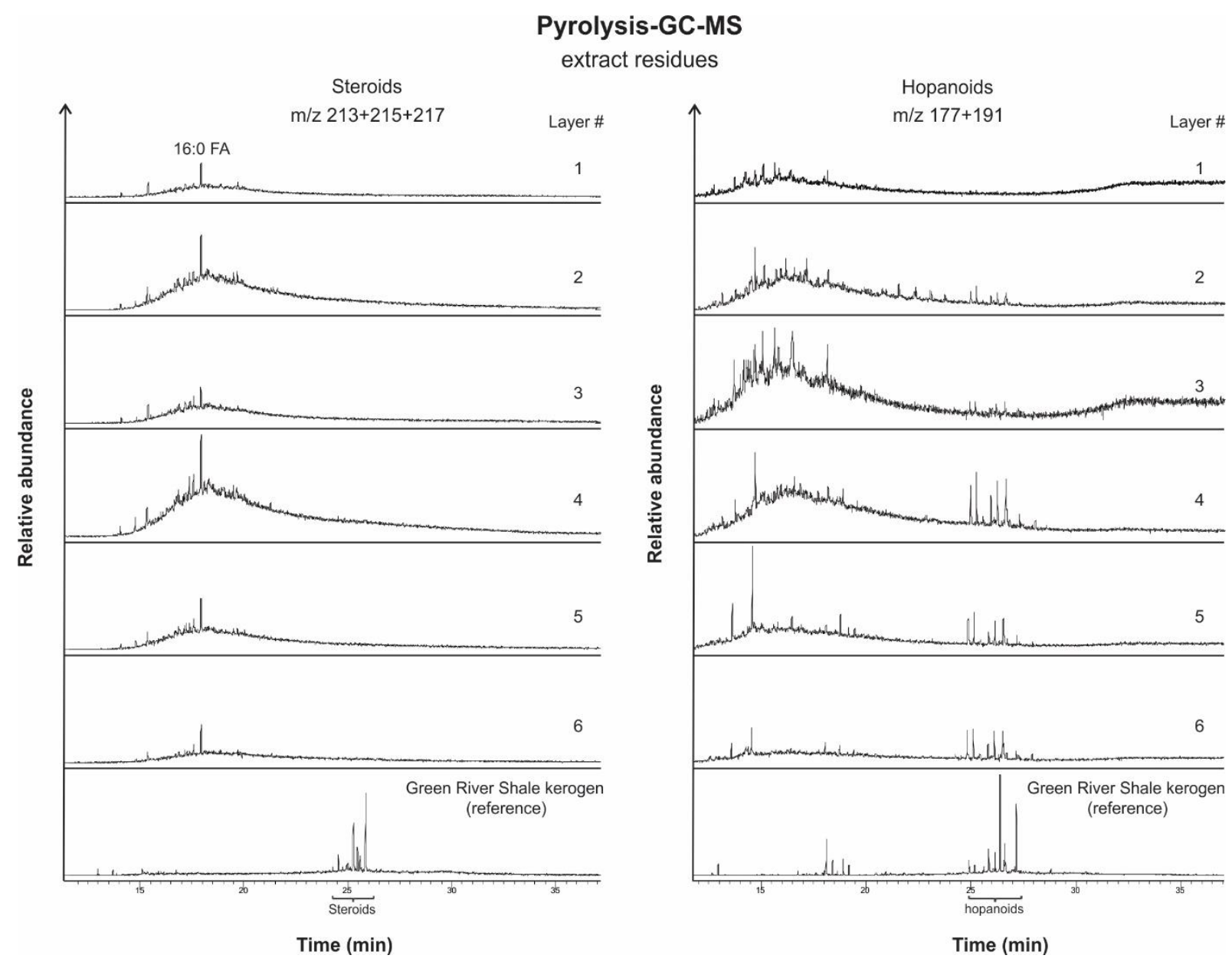

Figure B.2: Pyrolysis-GC-MS ion chromatograms showing the distributions of steroids $(\mathrm{m} / \mathrm{z}$ $213+215+217) v s$. hopanoids $(\mathrm{m} / \mathrm{z} 177+191)$ in the insoluble organic matter of the microbial mat layers (extraction residuesafter decalcification; Eocene Green River Shale for reference). 


\section{Freely extractable lipids}

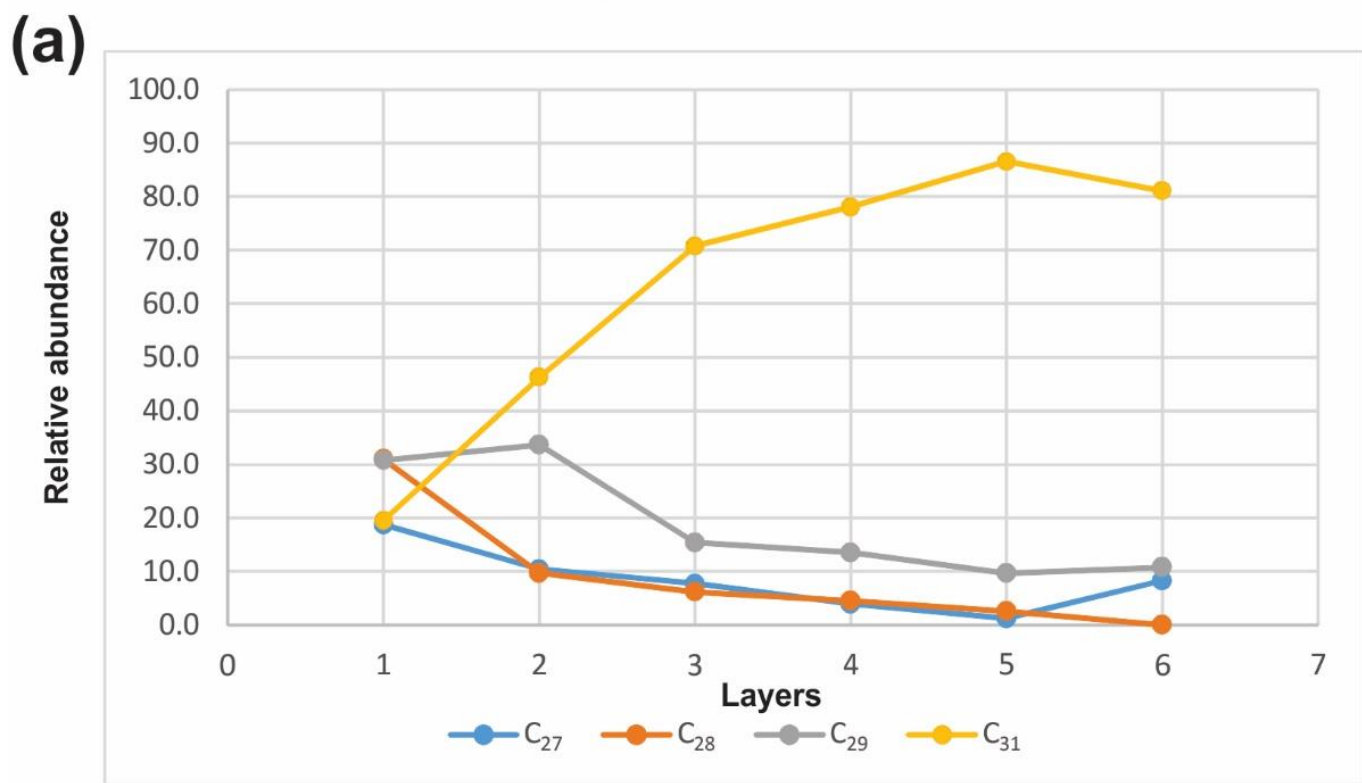

\section{Carbonate-bound lipids}

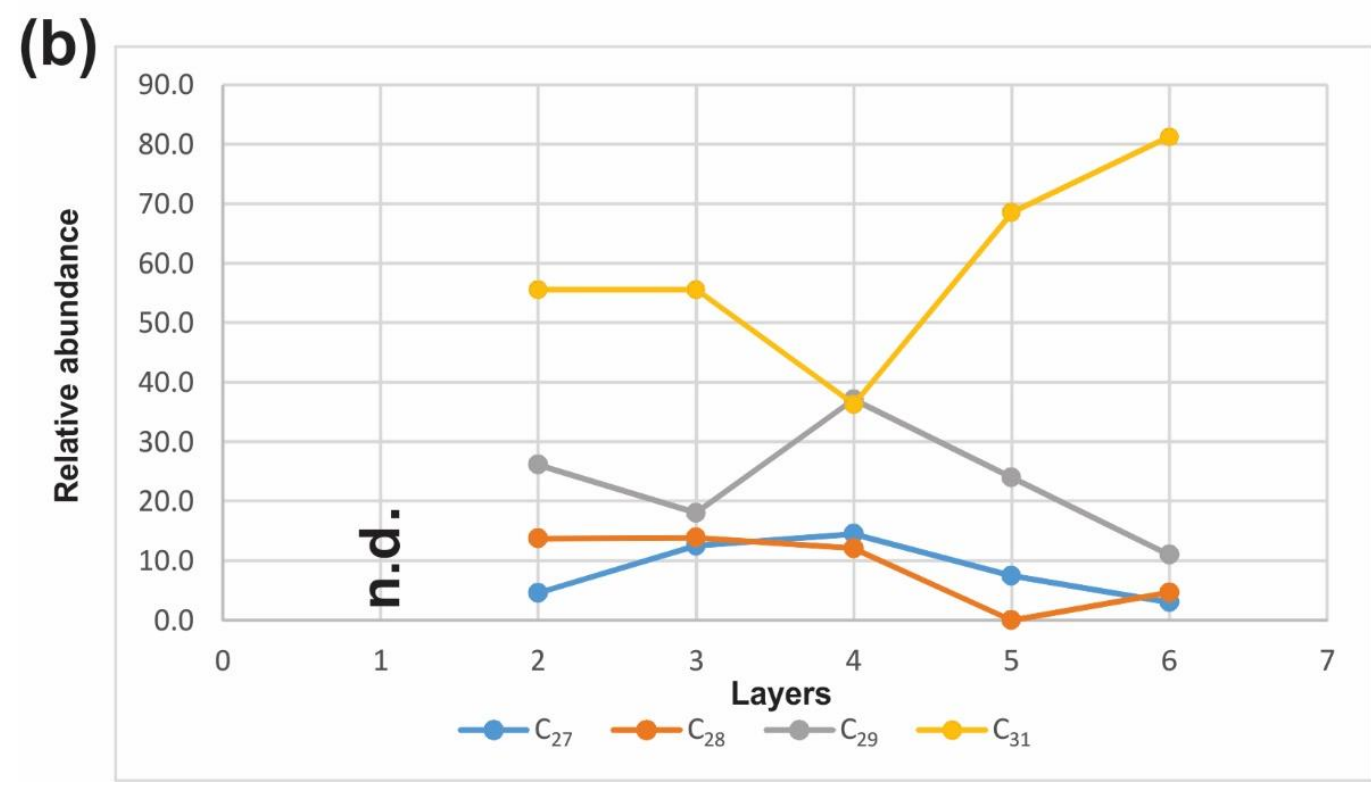

Figure B.3: Distributions of summed $\mathrm{C}_{27^{-}}$vs. $\mathrm{C}_{28^{-}}$-vs. $\mathrm{C}_{29^{-}}$-vs. $\mathrm{C}_{31}$-sterols in the (a) freely extractable lipids, and (b) carbonate-bound lipids of the microbial mat layers (in \% of the total). 


\section{$\underline{\text { Appendix C }}$}

\section{Supplementary material}

\section{Different modes of calcification control the preservation of organic matter in a recent microbial mat}

Table C.1: Concentrations of major fatty acids (FAs) and hopanoids (hop-17(21)-ene, hop-22(29)-ene, $\beta \beta$ bishomohopanoic acid, $\beta \beta$-bishomohopan-32-ol and $\alpha \beta$-trishomohopan-32-ol) in free- lipids of the microbial mat layers $(\mu \mathrm{g} / \mathrm{g}$ dry mat).

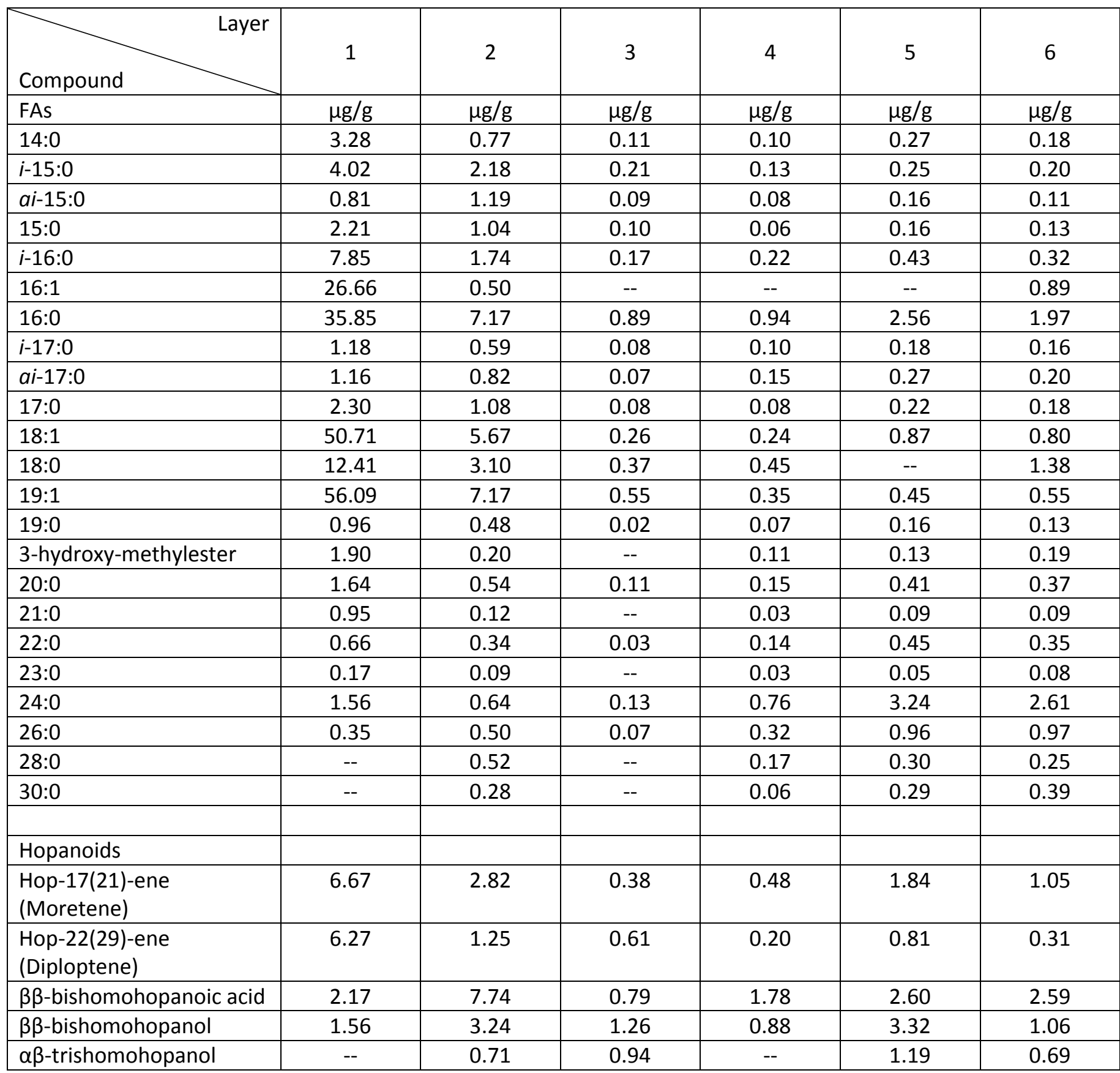


Table C.2: Concentrations of major fatty acids (FAs) and hopanoids (Hop-17(21)-ene, Hop-22(29)-ene, $\beta \beta$-bishomohopanoic acid, $\beta \beta$-bishomohopan-32-ol) in carbonate-bound lipids of the microbial mat layers $(\mu \mathrm{g} / \mathrm{g}$ dry mat).

\begin{tabular}{|c|c|c|c|c|c|c|}
\hline Compound & 1 & 2 & 3 & 4 & 5 & 6 \\
\hline FAs & $\mu \mathrm{g} / \mathrm{g}$ & $\mu \mathrm{g} / \mathrm{g}$ & $\mu \mathrm{g} / \mathrm{g}$ & $\mu \mathrm{g} / \mathrm{g}$ & $\mu \mathrm{g} / \mathrm{g}$ & $\mu \mathrm{g} / \mathrm{g}$ \\
\hline $14: 0$ & 0.37 & 0.25 & 0.65 & 0.19 & 0.18 & 0.12 \\
\hline$i-15: 0$ & 0.70 & 0.74 & 3.71 & 0.54 & 0.51 & 0.43 \\
\hline$a i-15: 0$ & 0.21 & 0.23 & 0.46 & 0.12 & 0.13 & 0.11 \\
\hline $15: 0$ & 0.28 & 0.42 & 0.92 & 0.27 & 0.26 & 0.26 \\
\hline$i-16: 0$ & 0.61 & 0.78 & 3.41 & 0.76 & 0.49 & 0.55 \\
\hline $16: 1$ & 1.13 & 0.36 & -- & -- & -- & -- \\
\hline $16: 0$ & 5.49 & 2.62 & 12.19 & 2.34 & 1.48 & 1.36 \\
\hline$i-17: 0$ & 0.12 & 0.31 & 1.34 & 0.26 & 0.14 & 0.19 \\
\hline$a i-17: 0$ & 0.14 & 0.31 & 1.31 & 0.27 & 0.18 & 0.22 \\
\hline $17: 0$ & 0.30 & 0.56 & 0.89 & 0.24 & 0.18 & 0.21 \\
\hline $18: 1$ & 3.49 & 0.91 & 1.41 & 0.31 & -- & 0.12 \\
\hline $18: 0$ & 2.59 & 1.29 & 4.97 & 1.36 & 0.62 & 0.61 \\
\hline 19:1 & 1.52 & 4.54 & 28.69 & 4.53 & 0.87 & 2.84 \\
\hline 19:0 & 0.05 & 0.17 & 0.25 & 0.11 & 0.09 & 0.04 \\
\hline 9,10-cyclopropyl-19:0 & 1.65 & 0.38 & 5.13 & 1.08 & 0.41 & 0.12 \\
\hline Methyl 3-hydroxy (12:0) & -- & 0.10 & 0.23 & 0.28 & 0.05 & 0.04 \\
\hline Methyl 3-hydroxy (14:0) & -- & 0.05 & 0.42 & 0.26 & 0.06 & 0.10 \\
\hline Methyl 3-hydroxy (16:0) & -- & 0.25 & 3.99 & 1.45 & 0.11 & 0.27 \\
\hline $20: 0$ & 0.08 & 0.18 & 0.62 & 0.31 & 0.06 & 0.08 \\
\hline $21: 0$ & 0.50 & 0.15 & 1.83 & 0.35 & 0.20 & 0.06 \\
\hline $22: 0$ & 0.10 & 0.17 & 1.04 & 0.59 & 0.11 & 0.07 \\
\hline $24: 0$ & 0.21 & 0.45 & 2.41 & 2.79 & 0.60 & 0.67 \\
\hline $26: 0$ & 0.09 & 0.15 & 0.65 & 0.85 & 0.14 & 0.17 \\
\hline $28: 0$ & -- & 0.12 & 0.49 & 0.47 & -- & -- \\
\hline Dioic acids-21:0 & & & 0.29 & 0.18 & -- & -- \\
\hline Dioic acids-22:0 & & & 0.38 & 0.17 & -- & -- \\
\hline Dioic acids-23:0 & & & 0.79 & 0.21 & -- & -- \\
\hline Dioic acids-24:0 & & & 0.27 & 0.18 & -- & -- \\
\hline Dioic acids-25:0 & & & 0.29 & 0.11 & -- & -- \\
\hline Dioic acids-26:0 & & & 0.38 & 0.15 & -- & -- \\
\hline Dioic acids-27:0 & & & 0.30 & 0.23 & -- & -- \\
\hline Dioic acids-28:0 & & & 0.74 & 0.26 & -- & -- \\
\hline & & & & & & -- \\
\hline Hopanoids & & & & & & -- \\
\hline Hop-17(21)-ene & -- & -- & 1.03 & 0.15 & -- & -- \\
\hline $\begin{array}{l}\text { Hop-22(29)-ene } \\
\text { (Diploptene) }\end{array}$ & -- & -- & -- & -- & -- & -- \\
\hline$\beta \beta$-bishomohopanoic acid & -- & 0.72 & 2.19 & 1.76 & 0.22 & 0.22 \\
\hline$\beta \beta$-bishomohopanol & -- & 0.22 & -- & 0.33 & -- & 0.50 \\
\hline
\end{tabular}


Table C.3: Concentrations of summed major hopanoids (hop-17(21)-ene, hop-22(29)-ene, $\beta \beta$ bishomohopanoic acid, $\beta \beta$-bishomohopan-32-ol and $\alpha \beta$-trishomohopan-32-ol), fatty acids (FAs) and steroids ( $\mu \mathrm{g} / \mathrm{g}$ dry mat) as well as steroids/hopanoids and steroids/FAs ratios in freely extractable lipids of the microbial mat layers.

\begin{tabular}{|c|c|c|c|c|c|}
\hline Layer & Hopanoids & FAs & Steroids & $\begin{array}{c}\text { Steroids*/ } \\
\text { Hopanoids }\end{array}$ & Steroids*/FAs \\
\hline 1 & 16.67 & 212.72 & 26.05 & 1.94 & 0.15 \\
\hline 2 & 15.76 & 36.73 & 2.22 & 0.26 & 0.11 \\
\hline 3 & 3.98 & 3.34 & 0.19 & 0.16 & 0.19 \\
\hline 4 & 3.34 & 4.74 & 0.15 & 0.20 & 0.14 \\
\hline 5 & 9.76 & 11.9 & 0.57 & 0.43 & 0.36 \\
\hline 6 & 5.70 & 12.5 & 0.19 & 0.18 & 0.08 \\
\hline
\end{tabular}

*including $\mathrm{C}_{31}$-sterols 
Table C.4: Concentrations of summed major hopanoids (hop-17(21)-ene, hop-22(29)-ene, $\beta \beta$ bishomohopanoic acid, $\beta \beta$-bishomohopan-32-ol), fatty acids (FAs) and steroids ( $\mu \mathrm{g} / \mathrm{g}$ dry mat) as well as steroids/hopanoids and steroids/FAs ratios in carbonate-bound lipids of the microbial mat layers.

\begin{tabular}{|c|c|c|c|c|c|}
\hline Layer & Hopanoids & FAs & Steroids & $\begin{array}{c}\text { Steroids*/ } \\
\text { Hopanoids }\end{array}$ & Steroids*/FAs \\
\hline 1 & -- & 19.63 & -- & -- & -- \\
\hline 2 & 0.94 & 15.49 & 0.27 & 0.65 & 0.04 \\
\hline 3 & 3.22 & 80.45 & 0.32 & 0.22 & 0.01 \\
\hline 4 & 2.24 & 21.22 & 0.79 & 0.55 & 0.06 \\
\hline 5 & 0.22 & 6.87 & 0.10 & 1.44 & 0.05 \\
\hline 6 & 0.72 & 8.64 & 0.14 & 1.01 & 0.08 \\
\hline
\end{tabular}

*including $\mathrm{C}_{31}$-sterols 


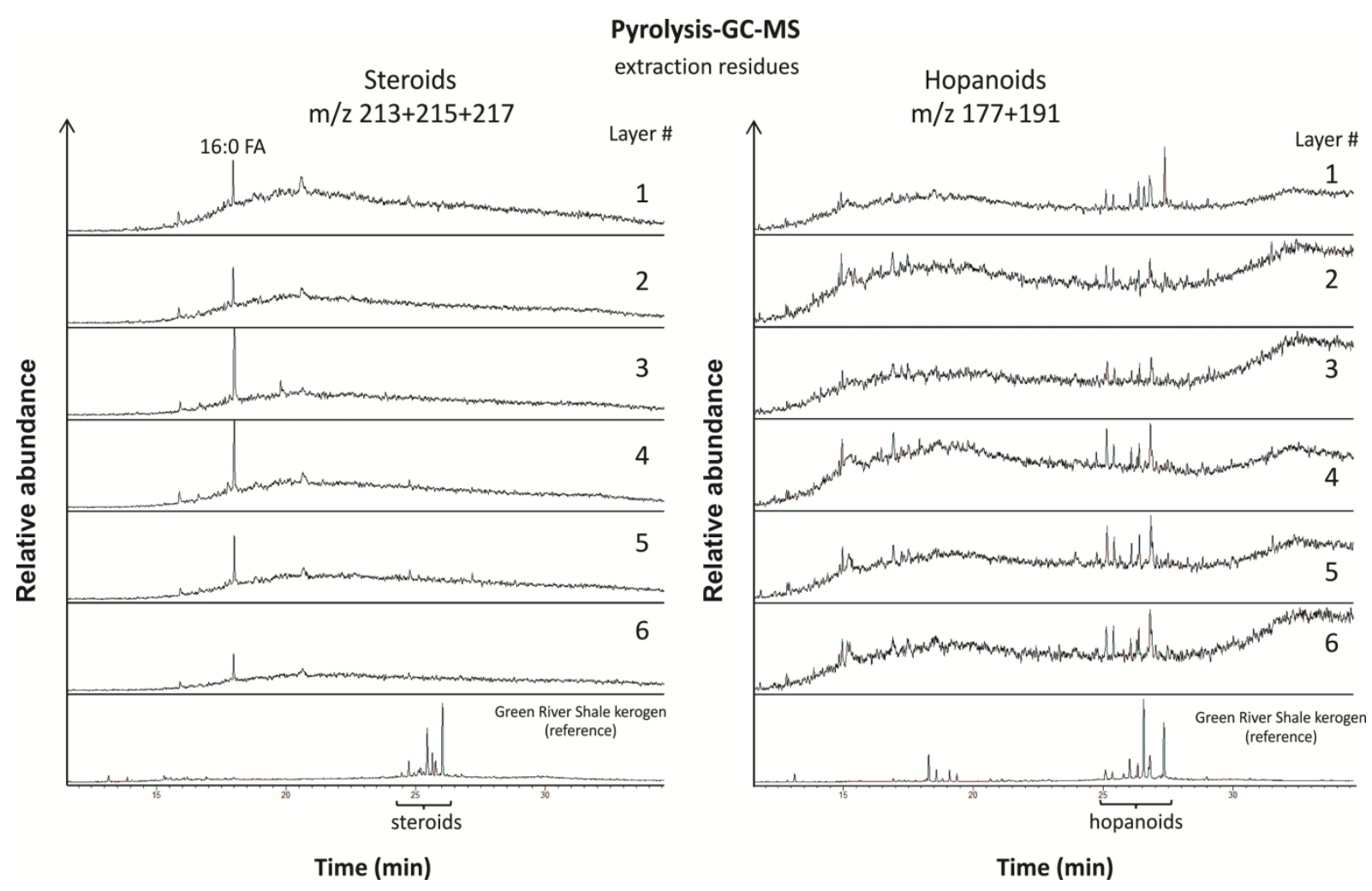

Figure C.1: Summed Pyrolysis-GC-MS chromatograms of steroids $(\mathrm{m} / \mathrm{z} 213+215+217)$ and hopanoids $(\mathrm{m} / \mathrm{z} 177+191)$ from the remaining extract residues within the microbial mat (Eocene Green River Shale for reference; data from Shen et al., 2019). 


\section{$\underline{\text { Acknowledgements }}$}

It is already more than three years since I started this $\mathrm{PhD}$ work. A lot of things happened, and some of them were quite miserable. In the end, I can still successfully complete the project; because I obtained generous supports from my parents, friends and colleagues who helped me to overcome and get through this phase. However, it is not possible to thank everyone here so my apologies to anyone that I have missed to mention.

First of all, I cordially thank my supervisors Joachim Reitner and Volker Thiel for giving me the chance to join such an exciting research field. They shared their knowledge and provided me guidance, continuous scientific supports and the opportunity to work independently, allowing me to become a highly-qualified young scientist.

Second, I am indebted to Gernot Arp, Pablo Suarez-Gonzalez, Sebastiaan Rampen, JanPeter Duda, Martin Blumenberg who offered critical and constructive comments that helped to further improve my papers. I am also appreciating Andreas Reimer that provided helpful discussions regarding the hydrochemical analysis and background information of research area. During the $\mathrm{PhD}$ study, I also received technical and laboratory assistance from Wolfgang Dröse, Birgit Röring, Dorothea Hause-Reitner, Jens Dyckmans. Certainly, I am also grateful to Gabriel Schmidt, Ines Ringel, Katrin Kranz, Jennifer Reinhold, Lin Wang for helping me to deal with other issues. Further, I want to thank Pablo Suarez-Gonzalez and Sebastiaan Rampen for proofreading parts of the thesis. Sandra Beckmann, Nadine Schäfer, Cornelia Hundertmark and Max Hundertmark are acknowledged for the administrative errands.

A tremendous gratitude goes to my parents, Wanying Zhou, Xianyi Shen. As your only child, I cannot accompany you and do anything for you when I pursued my study in Germany. Hence, I feel so guilty for my absence all the time. Even though, you always told me you can take good care of yourselves, and asked me just to focus on my works and to strive for my future. You have sacrificed too much for me and I would say that you are the greatest parents in the world and I am so proud of to be your kind! Getting through all the tough moment all these years, I have become a truly mature adult far beyond your expectation. Without you I would never be where I am today. So, mom and dad let me be your strong supports for the rest of the life. In addition, great thanks to my cousin, Xiulan Peng, for accompanying my 
mom, which indeed released part of my burden and reduced my guilty a little bit. I also want to thank myself for not giving up after plenty of dilemma happened that I was nearly crushed down. For the past three years, I always tried my best to accomplish the project, and cannot remember how many nights I spent in the lab/office where there are no other people in the whole building. I were kind of learning and enjoying that loneliness. So, again, I very appreciate my greatest efforts to accomplish these $\mathrm{PhD}$ works.

Last but not least, the German Research Foundation (DFG, project Re 665/18-2 and Research Unit 571 "Geobiology of Organo- and Biofilms") is kindly acknowledged for financial support for this thesis. 